Florida International University FIU Digital Commons

3-23-2009

\title{
Comparative Administrative Reform: The Rhetoric and Reality of the Civil Service Reform Programs in Uganda and Tanzania
}

Genevieve Enid Kyarimpa

Florida International University

DOI: $10.25148 /$ etd.FI10022527

Follow this and additional works at: https://digitalcommons.fiu.edu/etd

\section{Recommended Citation}

Kyarimpa, Genevieve Enid, "Comparative Administrative Reform: The Rhetoric and Reality of the Civil Service Reform Programs in Uganda and Tanzania" (2009). FIU Electronic Theses and Dissertations. 196.

https://digitalcommons.fiu.edu/etd/196 


\section{FLORIDA INTERNATIONAL UNIVERSITY}

Miami, Florida

COMPARATIVE ADMINISTRATIVE REFORM: THE RHETORIC AND REALITY

OF THE CIVIL SERVICE REFORM PROGRAMS IN UGANDA AND TANZANIA

A dissertation submitted in partial fulfillment of the

requirements for the degree of

DOCTOR OF PHILOSOPHY

in

PUBLIC MANAGEMENT

by

Genevieve Enid Kyarimpa

2009 
To: Dean Kenneth Furton

College of Arts and Sciences

This dissertation, written by Genevieve Enid Kyarimpa, and entitled Comparative Administrative Reform: The Rhetoric and Reality of the Civil Service Reform Programs in Uganda and Tanzania, having been approved in respect to style and intellectual content, is referred to you for judgment.

We have read this dissertation and recommend that it be approved.

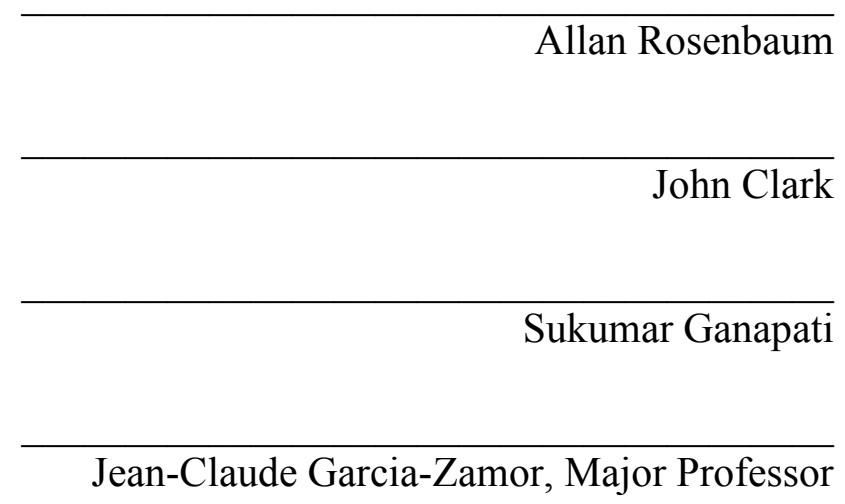

Date of Defense: March 25, 2009

The dissertation of Genevieve Enid Kyarimpa is approved.

Dean Kenneth Furton
College of Arts and Sciences

Dean George Walker University Graduate School

Florida International University, 2009 
(C) Copyright 2009 Genevieve Enid Kyarimpa

All rights reserved. 


\section{DEDICATION}

I dedicate this dissertation to my late father, Joseph K. Macumu. I miss you dreadfully. I always will. You told me to always aim higher, I did. Look down and smile with me. Thank you for teaching me to value education, hard work, commitment, and perseverance. 


\section{ACKNOWLEDGMENTS}

My dissertation would not have come to fruition without the effort of various people. My committee members: thank you for the guidance, encouragement, support, constructive criticism, and keen interest in my study. You have all inspired me both professionally and personally, and strengthened my self-belief. Professor Jean-Claude Garcia-Zamor, my committee chair, thank you for nurturing my interest in administrative reform. Your dedication to my academic growth manifested in every meeting we had, in the advice and comments you gave me, and in all academic endeavors we shared.

Professor Allan Rosenbaum, with much passion and ingenuity, you gently guided me into the world of comparative administration, and deepened my interest in the field. Your commitment to see me succeed was enormous. Thank you for having faith in me. Dr. Sukumar Ganapati, you gave me highly critical and invaluable suggestions to strengthen the study and in the same breath, you were kind and reassuring. Thank you. Last but not least, gratitude goes to Dr. John Clark. Your love and passion for Uganda and Africa in general are special. When I met you in Uganda in 1999 I did not know how greatly you would influence my academic journey. Thank you for encouraging me to come to FIU, and for making my stay less "home sick." Thank you for being a critical eye, pointing out inconsistencies, and ensuring that my analysis is not biased.

I am very grateful to my study participants in Uganda and Tanzania, who in spite of their tight schedules set aside time to talk to me about the various reforms in their Ministries. Their dedication to their work, their optimism, and their belief in better public service systems are truly exceptional. 
My many friends here at FIU and back home at Makerere University, you are so many that I cannot exhaustively identify you and sufficiently acknowledge you. I am very grateful for the warm support, kindness, motivation, encouragement, and love that you continue to give me.

I would like to thank my family in Uganda. My mother Restituta K. Macumu, thank you very much for the love and prayers. Your support and encouragement have been invaluable. To all my siblings, thank you too for the prayers and support. Special thanks however go to my sister Maureen. Thank you for everything. The phone calls, the emails, the packages, field work support, the visits, the laughter ...the list goes on.

Gratitude also goes to my surrogate family here in Miami. To the Jacob family, thank you for embracing me. Special gratitude goes to the late Celine Jacob, thank you for the love, encouragement, and inspiration. May your soul rest in eternal peace.

To my family in Michigan, thank you for everything. Mom Mary K. Meyers, thank you for being a very loving mother. The phone calls, cards, and packages made me smile and brightened my days.

Finally, I want to thank Mike, my love, my husband. What an opportune time to come into my life. Through many difficult and trying times, you have been my rock. Your love and support inspired in me the resolve and stamina to finish this dissertation. Thank you for the morning, lunch time, and evening calls. Thank you for the wake up and goodnight calls; for the laughter when I needed cheering, and for the ears when I needed to vent. The separation has been hard; but you have truly embodied the biblical saying "Love is patient." With much love, I thank you. 


\section{ABSTRACT OF THE DISSERTATION}

COMPARATIVE ADMINISTRATIVE REFORM: THE RHETORIC AND REALITY

OF THE CIVIL SERVICE REFORM PROGRAMS IN UGANDA AND TANZANIA

by

Genevieve Enid Kyarimpa

Florida International University, 2009

Miami, Florida

Professor Jean-Claude Garcia-Zamor, Major Professor

Administrative reform is a challenging endeavor for both developed and developing countries alike. For developing countries, the challenge is greater because numerous reforms are implemented concurrently sometimes under conditions of resource scarcity and political instability. So far there is no consensus as to what makes some reforms succeed and others fail. The current study seeks to fill that gap by offering an empirical comparative analysis of the administrative reforms initiated in Uganda and Tanzania since the early 1990s. The purpose of the study is to explain the similarities and differences, and give reasons for the successes and failures of the reform programs in the two countries. It focuses on four major areas; the size of the civil service, pay reform, capacity building, and ethics and accountability.

Data were collected via in-depth face to face interviews with 35 key government officials and the content analysis of various documents. The results indicate that the reforms generated initial substantial reduction in the size of the public services in both countries. In Uganda, the traditional civil service was reduced from 140,500 in 1990 to 41,730 in 2004; while in Tanzania Ministries, Departments, and Agencies were reduced 
by $25 \%$. Pay reform has generated substantial increases in civil servants' salaries in both countries but in Uganda, the government has not been able to abide by the pay strategy while in Tanzania the strategy guides the increments.

Civil Service capacity building efforts have focused on enhancing the skills of the personnel. Training needs assessments were undertaken in all ministries in Uganda and a training policy was formulated. In Tanzania, the training needs assessments are still under way and a training policy has not yet been developed. Ethics and accountability are great challenges in both countries, but in Tanzania, there is more political will and commitment to improve the integrity of the civil service.

The findings reveal that although Uganda started the reform with much more rigor and initial success, Tanzania has surpassed it and has a more stable, consistent, and promising reform record. This is because Uganda's leadership lacks political legitimacy. The country has since the late 1990s experienced a civil war in the northern and western parts of the country while Tanzania has benefitted from relative peace and high level political legitimacy. 


\section{TABLE OF CONTENTS}

CHAPTER

PAGE

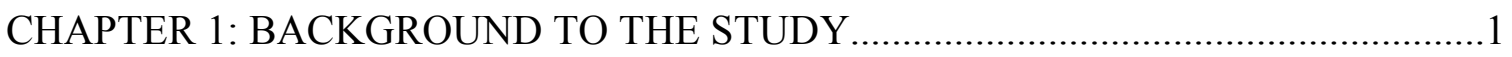

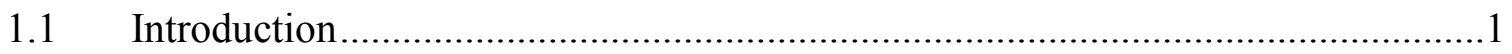

1.2 The Research Problem .................................................................................

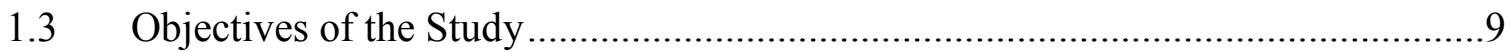

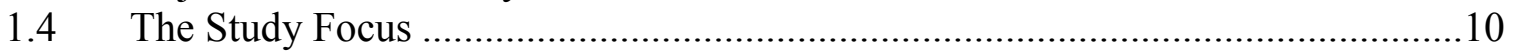

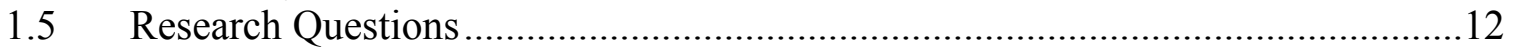

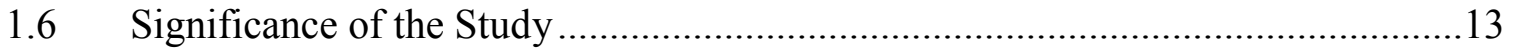

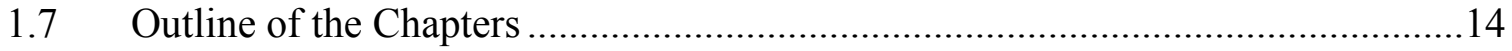

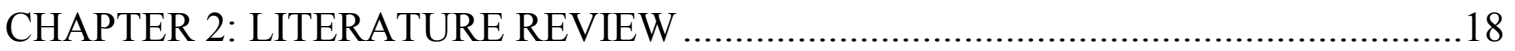

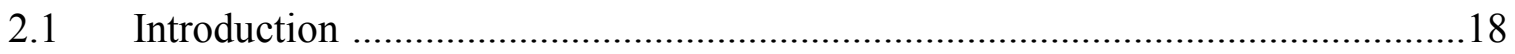

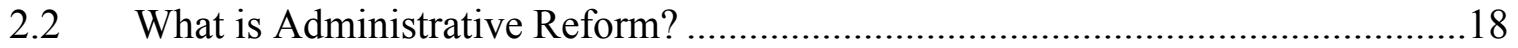

2.3 The Bureaucratic Paradigm, Administrative Reform, and Governance .................30

2.3.1 The Role of the Bureaucracy in Administrative Reform .........................................34

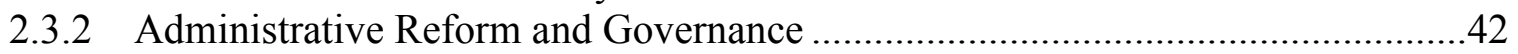

2.4 New Public Management and Administrative Reform .........................................48

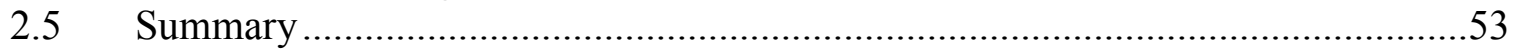

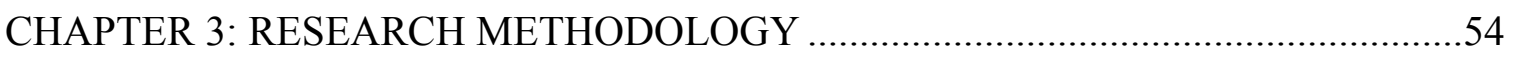

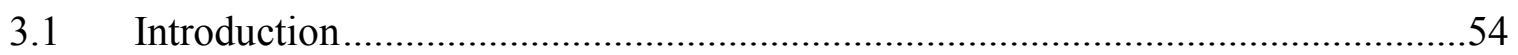

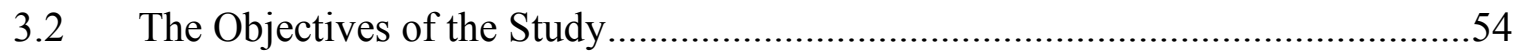

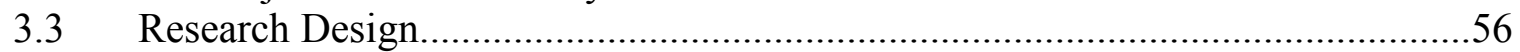

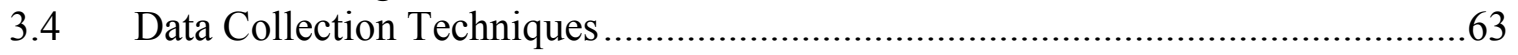

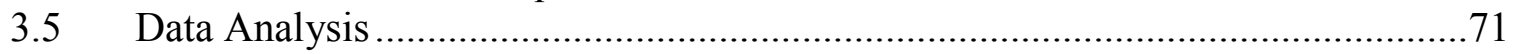

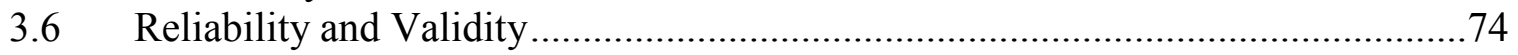

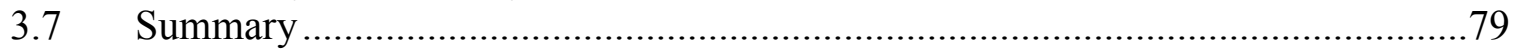

CHAPTER 4: COLONIAL HERITAGE AND BUREAUCRATIC DEVELOPMENT IN UGANDA AND TANZANIA: A HISTORICAL OVERVIEW …………….................

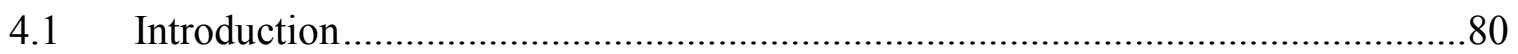

4.2 Administration in Indigenous Territories in Pre-colonial Uganda .........................81

4.3 Administration in Indigenous Territories in Pre-colonial Tanzania .......................96

4.4 Colonial Heritage and Bureaucratic Development in Uganda and Tanzania .......108

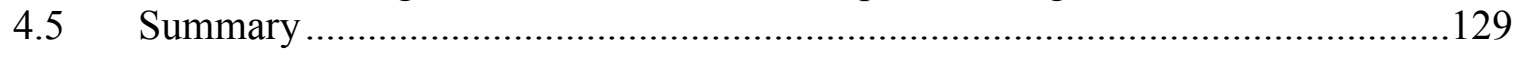

CHAPTER 5: STATE COLLAPSE IN UGANDA AND ECONOMIC

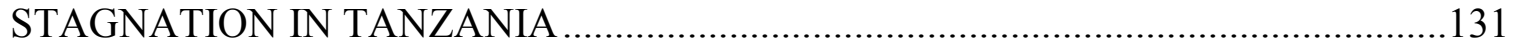

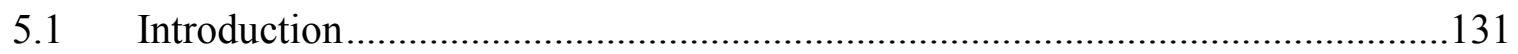

5.2 Uganda's Political History: From Independence to State Collapse.......................132

5.3 From Obote to Amin and back to Obote: Militarism and State Collapse.............140

5.4 Economic Collapse in Post-Independence Uganda ..............................................150 
5.5 From the Brink: The NRM and State Reconstruction in Uganda......................153

5.6 The Civil Service Reform Program in Uganda.................................................158

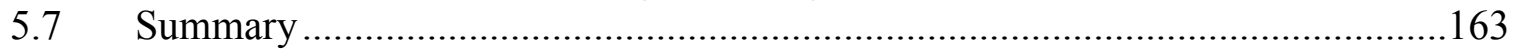

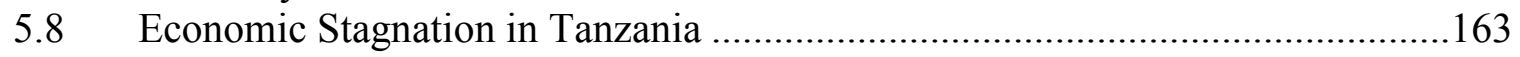

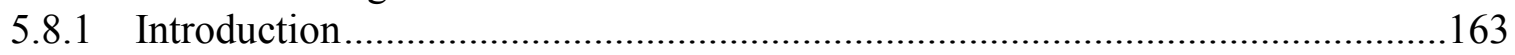

5.9 From Colonialism to Ujamaa African Socialism.......................................... 164

5.10 African Socialism Unrealized: The Tanzanian Economic Crisis 1975-1985 ......173

5.11 Embracing the Market: The Economic Recovery Program in Tanzania .............180

5.12 The Public Sector Reforms in Tanzania ..........................................................183

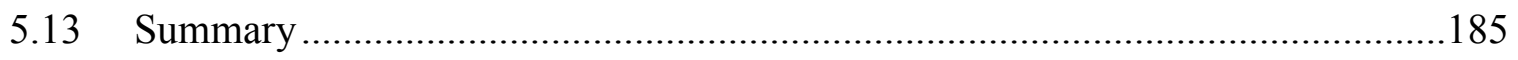

CHAPTER 6: THE CIVIL SERVICE REFORM PROGRAM IN UGANDA: AN

ANALYSIS OF THE FINDINGS ..................................................................... 187

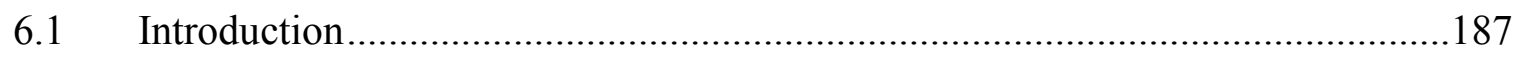

6.2 Doing More with Less: The Reduction of the Size of the

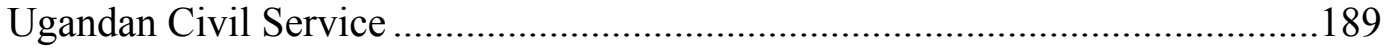

6.2.1 Rationalization and Restructuring of Ministries and Districts..........................190

6.2.2 Down Sizing the Civil Service through Retrenchment and Voluntary

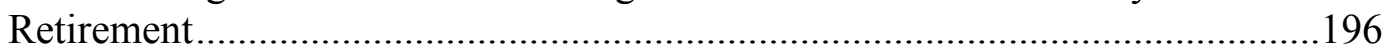

6.2.3 Challenges in the Reduction of the CS Size .....................................................208

6.2.4 The Reduction of the Size of the Ugandan CS: Rhetoric or Reality?..................215

6.3 Improving Remuneration: The Politics of Pay Reform in the Uganda CSRP .....217

6.3.1 Salary Enhancement: The Pursuit of the Minimum Living wage.......................221

6.3.2 Elimination of Allowances and Monetization of Non-cash Benefits ..................226

6.3.3 Rationalization of the Pay and Grading System .............................................229

6.3.4 The Politics of Pay Reform in Uganda .........................................................234

6.3.5 Improving Remuneration in the Uganda CS: Rhetoric or Reality? ....................243

6.4 Capacity Building and the Uganda CSRP .....................................................245

6.4.1 Capacity Building: Training and Infrastructure Development ..........................246

6.4.2 The Uganda Public Service Training Policy ...................................................252

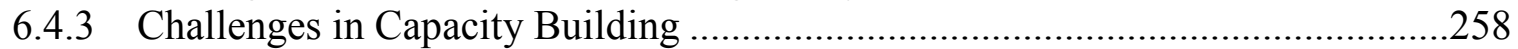

6.5 Ethics and Accountability in the Uganda Civil Service Reform Program...........260

6.6 Challenges in Enhancing Ethics and Accountability in the Uganda CS.............272

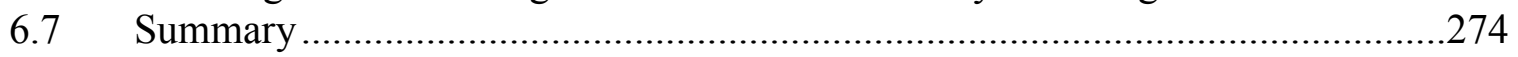

CHAPTER 7: THE CIVIL SERVICE REFORM PROGRAM IN TANZANIA:

AN ANALYSIS OF THE FINDINGS ................................................................279

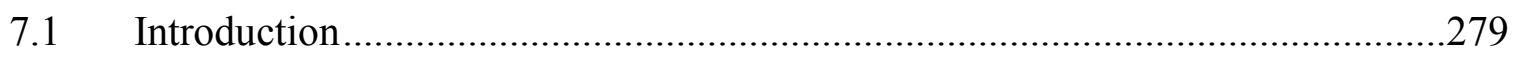

7.2 Reduction of the Size of the Tanzanian Civil Service ........................................280

7.2.1 Doing More with Less: The Reduction of the Size of the Tanzanian Civil

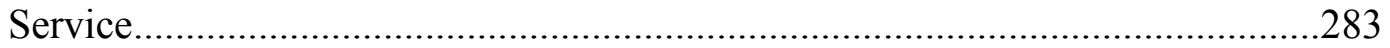

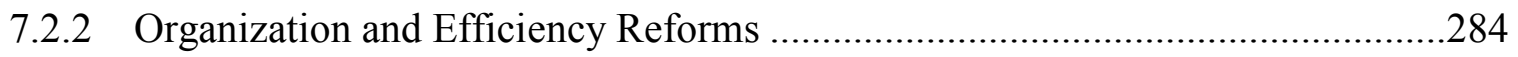

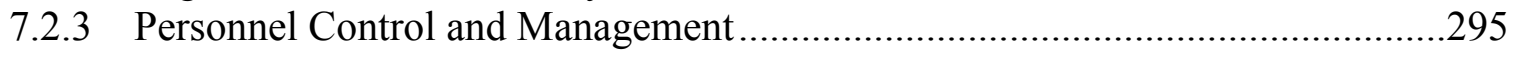

7.2.4 Rationalization of Government Employment .............................................298 
7.2.5 The Reduction of the Size of the Tanzanian Civil Service:

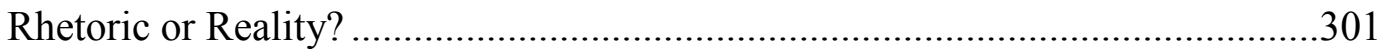

7.3 Pay Reform and the Tanzanian Civil Service Reform Program ...........................303

7.3.1 Rationalization of the Pay Structure .................................................................309

7.3.2 Salary Enhancement: Designing an Appropriate Remuneration System .............314

7.3.3 Enhancing Civil Service Remuneration in Tanzania: Rhetoric or Reality? .........322

7.4 Capacity Building in the Tanzanian Civil Service Reform ..................................327

7.4.1 Public Service Reform 2000 - 2007 and Capacity Building ................................329

7.4.2 Capacity Building in the Tanzanian CSRP: Rhetoric or Reality? ........................333

7.5 Ethics and Accountability in the Tanzanian CSRP...............................................333

7.5.1 Challenges in Enhancing Ethics and Accountability in the Tanzanian CS .........347

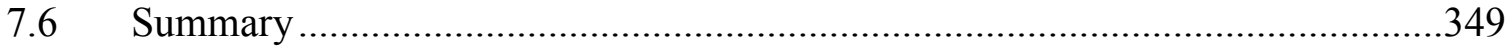

CHAPTER 8: THE CIVIL SERVICE REFORM PROGRAMS IN UGANDA

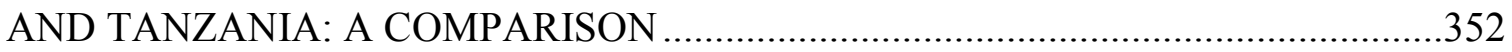

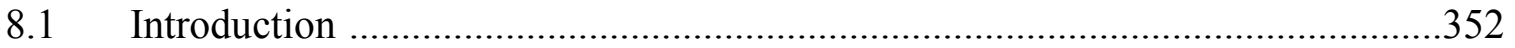

8.2 The Nature of the Political Leadership .............................................................352

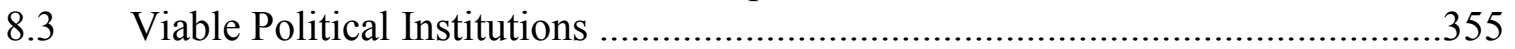

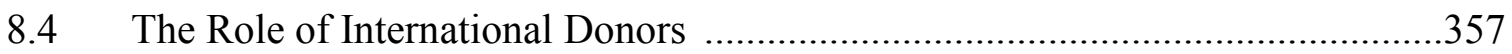

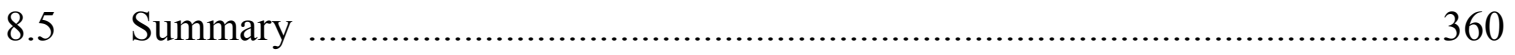

CHAPTER 9: CONCLUSIONS AND RECOMMENDATIONS .....................................361

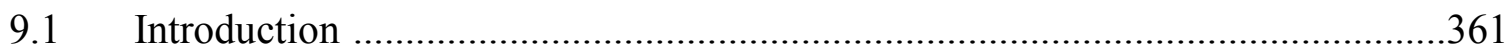

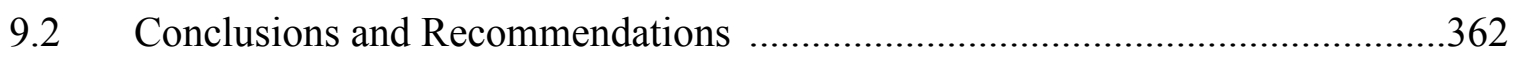

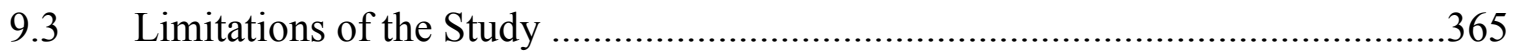

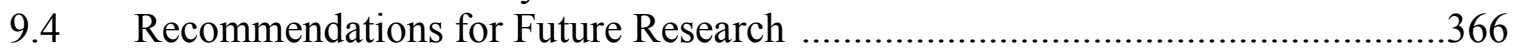

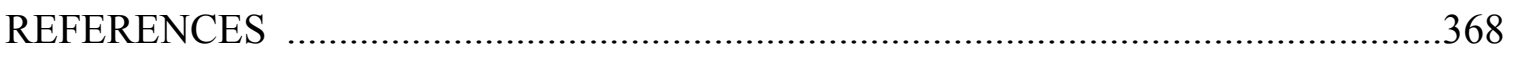

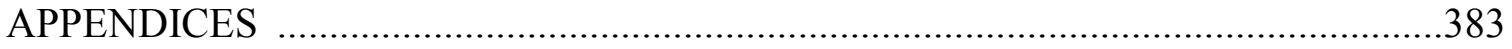

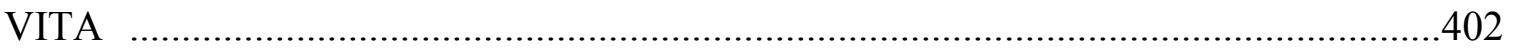




\section{LIST OF TABLES}

TABLE

PAGE

\section{CHAPTER 3}

3.1 Demographic Characteristics of the Study Sample ..........................................64

3.2 Criteria for Judging Research Quality in Qualitative and Quantitative Studies ....76

CHAPTER 4

4.1 Population Statistics of the Three Eastern African Countries at the onset of British Colonialism

4.2 Levels of Pre-colonial Development and Colonialism in a few British Colonies

\section{CHAPTER 5}

5.1 Chronology of Military Coups and Armed take-over in Post-Independence Uganda

5.2 Data for the Pre-Arusha Declaration Period 1961-1967. 166

5.3 Data for Pre-crisis Period 1968-1978

5.4 Trends in Select Economic Indicators for the Period 1979-1985 .178

5.5 Trends in Selected Macroeconomic Indicators: 1996-2003 183

CHAPTER 6

6.1 Actual and Target Civil Service Staffing Levels $1990-1995$

6.2 Planned Action for Fast Retrenchment 198

6.3 Uganda Retrenchment Packages, 1995-1997

6.4 Summary of the Cases handled under the Special Voluntary Retirement Scheme - 1998 .205

6.5 The Size of the Civil Service (old definition) for the Years 1990-1998 .............206

6.6 The Size of the Public Service June 1999 - June 2004 ...................................216

6.7 Major Problems in the Civil Service Pay and Envisaged Solutions ...................220

6.8 Projected Minimum Living Wage (Uganda Shillings) ...................................223 
6.9 Civil Service Salaries for the Years 1993 and 1997 (select civil servants) in US Dollars Equivalent

6.10 Consolidated Civil Service Pay (Ug. Shs. gross per month)

6.11 Illustration of the Civil Service Median Pay, Job Evaluation Median Pay, and Market Median Pay Levels

6.12 Performance of Pay Reform Strategy on Public Service Salary based on the Median Monthly Salary in Uganda Shillings

6.13 Pay Disparity within the Public Service (Gross Pay)

6.14 Pay Reform Wage Bill provision for the Period 2001/02 - 2005/06 (Billion Uganda Shillings)

6.15 Issues in Training and Recommended Policy Shifts.

6.16 Uganda's Corruption Perception Index (CPI) Ranking, 1998-2008 .273

\section{CHAPTER 7}

7.1 Private Sector Participation in the Provision of Non-core Services .291

7.2 Impact of Organization and Efficiency Review (O\&E) 1993-1997 ..................296

7.3 Major Job Classes .300

7.4 Comparative Sector Compensation Levels for Select Job Categories (November 1996)

7.5 Some Fast Growing Components of the Other Charges Budget

7.6 Assumptions in the Medium Term Pay Reform Strategy .................................317

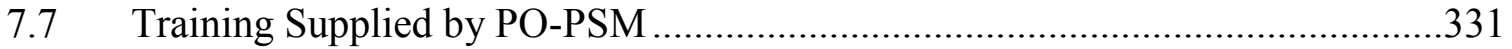

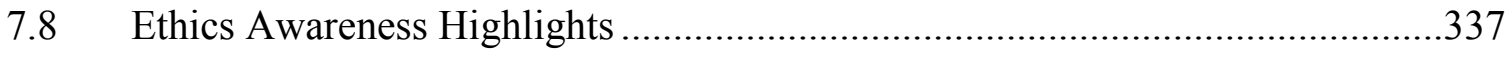

7.9 Tanzania’s Corruption Perception Index Ranking, 1998-2008 ........................345

CHAPTER 8

8.1 Comparisons of Civil Service Reforms in Uganda and Tanzania .359 


\section{LIST OF FIGURES}

FIGURE

PAGE

\section{CHAPTER 5}

5.1 A contextual Framework of the Reforms undertaken by the NRM in the early 1990s

5.2 The Phases of the CSRP/PSRP in Tanzania

CHAPTER 6

6.1 The Size of the Civil Service for the Years 1990-1998 ...................................207

6.2 Size of the Ugandan Civil Service 1990 - 2004 ............................................217

6.3 Linkages between CAPEP and Ongoing Public Sector Reform Programs .........258

\section{CHAPTER 7}

7.1 Phases of the Ministerial Organization and Efficiency Review .........................285

7.2 Percentage of Public Servants who are Operational Staff in Central Ministries at the National level for the Years 2000 to 2006

7.3 Size of the Tanzanian Civil Service, 1993-2004 .303

7.4 Civil Service Expansion and Stagnating GDP, 1970-1984 ...............................306

7.5 Real Civil Service Average Pay Trend, 1969-1998 ........................................309

7.6 Average Pay Levels (Tanzanian Shillings) 2000 - 2007 .................................319

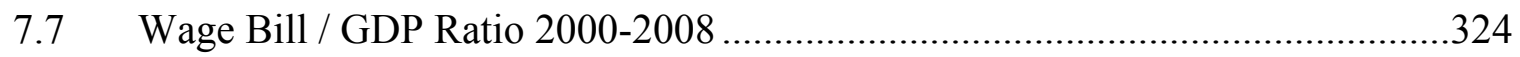

7.8 Civil Servants' Average Salaries as a Percentage of Private Sector Average Salaries for Similar Jobs in 2006. .326

7.9 Number of Suspended Public Servants per 100,000 Public Servants.................339

7.10 PO-PSM Assessments on Changes in Corruption .344 


\section{LIST OF ACRONYMS}

\begin{tabular}{|c|c|}
\hline $\mathrm{AG}$ & Auditor General \\
\hline ARS & Administrative Reform Secretariat \\
\hline CAPEP & Capacity and Performance Enhancement Project \\
\hline CPI & Corruption Perception Index \\
\hline $\mathrm{CS}$ & Civil Service \\
\hline CSD & Civil Service Department \\
\hline CSR & Civil Service Reform \\
\hline CSRP & Civil Service Reform Program \\
\hline DEI & Directorate of Ethics and Integrity \\
\hline DP & Democratic Party \\
\hline DPP & Director of Public Prosecutions \\
\hline DRTF & District Review Task Force \\
\hline EDSP & Education Sector Development Program \\
\hline ERP & Economic Recovery Programme \\
\hline EU & European Union \\
\hline GDP & Gross Domestic Product \\
\hline GGCU & Good Governance Coordination Unit \\
\hline HRM & Human Resource Management \\
\hline $\mathrm{ICT}$ & Information Communication Technology \\
\hline IFMS & Integrated Financial Management Systems \\
\hline IGG & Inspector General of Government \\
\hline IMF & International Monetary Fund \\
\hline
\end{tabular}




$\begin{array}{ll}\text { KY } & \text { Kabbaka Yekka } \\ \text { LC } & \text { Local Council } \\ \text { LGRP } & \text { Local Government Reform Program } \\ \text { MDAs } & \text { Ministries Departments and Agencies } \\ \text { MLW } & \text { Minimum Living Wage } \\ \text { MOE } & \text { Ministry of Education } \\ \text { MOF } & \text { Ministry of Finance } \\ \text { MOLG } & \text { Ministry of Local Government } \\ \text { MRC } & \text { Ministerial Reform Committees } \\ \text { MTEF } & \text { Medium Term Expenditure Framework } \\ \text { MTPP } & \text { Medium Term Pay Policy } \\ \text { MTPRS } & \text { Medium Term Pay Reform Strategy } \\ \text { NACSAP } & \text { National Anti-Corruption Strategy and Action Plan } \\ \text { NCC } & \text { National Consultative Council } \\ \text { NPM } & \text { New Public Management } \\ \text { NRA } & \text { National Resistance Army } \\ \text { NRM } & \text { National Resistance Movement } \\ \text { O\&E } & \text { Organization and Efficiency } \\ \text { ODA } & \text { Overseas Development Agency } \\ \text { OECD } & \text { Organization for Economic Co-operation and Development } \\ \text { OPM } & \text { Office of the Prime Minister } \\ \text { OPRAS } & \text { Open Performance Review Appraisal Systems } \\ \text { Public Accounts Committee } \\ \text { MA }\end{array}$




\begin{tabular}{ll} 
PCB & Prevention of Corruption Bureau \\
PEAP & Poverty Eradication Action Plan \\
PEDP & Primary Education Development Program \\
PO-PSM & President's Office - Public Service Management \\
PSC & Public Service Commission \\
PSRC & Poverty Reduction Support Credit \\
PSRP & Public Service Reform Program \\
PSRRC & Public Service Review and Reorganization Commission \\
RC & Resistance Council \\
RCs & Resistance Councils \\
ROM & Results Oriented Management \\
SAPs & Structural Adjustment Programmes \\
SASE & Selective Accelerated Salary Enhancement \\
SDP & Sector Development Program \\
TGDLC & Tanzania Global Distance Learning Centre \\
TIMB & The Implementation and Monitoring Board \\
TPSC & Tanzania Public Service College \\
TRA & Tanzania Revenue Authority \\
TShs & Tanzania Shillings \\
TTG & Technical Task Group \\
UIA & Uganda Investment Authority \\
Und & Unanda National Congress \\
\hline
\end{tabular}




$\begin{array}{ll}\text { UPC } & \text { Uganda People's Congress } \\ \text { UPE } & \text { Universal Primary Education } \\ \text { UPM } & \text { Uganda People's Movement } \\ \text { URA } & \text { Uganda Revenue Authority } \\ \text { UShs } & \text { Uganda Shillings } \\ \text { VR } & \text { Voluntary Retirement }\end{array}$




\section{CHAPTER 1: BACKGROUND TO THE STUDY}

\subsection{INTRODUCTION}

The present comparative study assesses the performance of the civil service reforms undertaken in two East African countries, Uganda and Tanzania. The two countries, both originally under British colonial administration (Tanzania was a British administered UN Trusteeship), attained their independence in 1962 and 1961 respectively. Uganda, a relatively small country that covers an area of 241,038 square kilometers, of which 82 percent is land, has a population of 24.4 million people (2002 Population Census) while Tanzania, a far larger country covering 945, 000 square kilometers, has a population of 34.4 million people (2002 Population Census). The Civil Service (CS), also known as the public service in both countries, is the operational arm of government, and is charged with analysis, recommendation, and administration of public policy.

The civil service systems in the two countries have had a long history, dating as far back as the colonial period. Some of the problems that emerged during that era are still prevalent. In addition, the functions and structure of the Ugandan and Tanzanian CS have, over time, been shaped by historical, economic, political and ideological factors. The CS system that was inherited from the colonial regime at independence by both countries was relatively small, with its objectives primarily focused on the maintenance of law and order. More than forty years later, these systems have changed both in structure and functions. Besides maintaining law and order, the CS has increasingly become the vehicle for social and economic development. 
It should however be noted that the historical, political, economic, and ideological factors manifest themselves differently in the two countries. Therefore, the CS systems in both countries took, over time, differing paths and evolved differently. The objective of this research is to answer the question: why do some reforms succeed and others fail? To meet my objective, the study traces the development of the civil service systems in both countries, illustrates the differing paths of this development, and critically analyzes the outcomes of the reform programs instituted since the early 1990s. The study empirically examines why or why not, and the extent to which the reforms have attained their goals and objectives based on the perceptions of the public servants involved in the reform process.

\subsection{THE RESEARCH PROBLEM}

Administrative reform is a challenging endeavor for both developed and developing countries alike. Indeed, there is no consensus as to what makes some reforms succeed while others fail. Yet, reform of the administrative system is not new. Prior administrative reform efforts, for instance, in the nineteenth century, aimed at stamping out the spoils system, and establishing efficient, effective, and economic administrative systems. Earlier decades of the twentieth century saw the focus shift to "institution building, bureaucratization, nationalization, and a wide variety of organizational and administrative capacity building for national and economic development."1 Contemporary reform efforts on the other hand are part of a wider New Public

\footnotetext{
${ }^{1}$ Farazmand, A. (ed.) 2002. Administrative Reform in Developing Nations. Westport, CONN: Praeger, p. ix.
} 
Management (NPM) movement geared towards reversing the traditional role of government by shrinking the size of the civil service, reducing both administrative and financial waste, and improving performance and productivity, accountability, service provision, and general capacity of the administrative system.

The relevance of the NPM movement to the developing countries and the level of its implementation therein is still a matter of contention (Minogue, Polidano, and Hulme, 1998; McCourt and Minogue, 2001; Dibben, Wood, and Roper, 2004). According to Polidano (2001), "while many developing countries have taken up elements of the NPM agenda, they have not adopted anything close to the entire package." He asserts further that countries are implementing numerous reforms concurrently some unrelated and even contrary to the NPM ideals. In his view, the NPM "is only one among a number of contending strands of reform in the developing world."2 Indeed in the Ugandan and Tanzanian cases, some aspects of NPM are evident. Among them are the reduction in the size of the CS, commonly referred to as "retrenchment," and privatization.

Since the 1980s, administrative reform has become a catchword for numerous countries. According to Pollit and Bouckaert (2000), a wave of civil service reforms swept across many of the OECD countries since the 1980s, reshaped the manner in which public budgets are managed, considerably altered many lives of public officials, and in some countries a number of previously public- owned enterprises have been privatized. They assert further that resultant from the reforms, "large claims have been made for

\footnotetext{
${ }^{2}$ Polidano, C. 2001. "Administrative Reform in Core Civil Services: Application and Applicabilit of the New Public Management.” In McCourt, W. and Martin Minogue. The Internationalization of New Public Management: Reinventing the Third World State. Cheltenham, UK: Edwad Elgar, pp. 45-46.
} 
'savings' and 'efficiency gains"” but are quick to add that such claims are "seldom straightforward and uncontestable." ${ }^{3}$ The picture is not that different in the developing world.

With specific reference to Uganda and Tanzania, administrative reform efforts have been pursued with a mixture of great zeal and caution. Prior to colonialism, neither country had any modern-day administrative systems to boast of. However, the onset of colonialism brought with it western-style bureaucratic organizations to the colonies. The newly imposed administrative systems were mechanisms for control and subjugation rather than for serving and entrenching administrative ideals. As such, focus was placed on maintaining law and order, collecting taxes, and ensuring the colonial master's interests rather than training, developing and creating viable administrative infrastructures manned by the natives. Mutahaba and Halfani (1993:7) put it succinctly when they assert that the organization of the colonial administration was "highly hierarchical, inhibiting lower-level participation in decision making, and since it was in the service of the colonial masters, it was highly suppressive and did not respond to public demands."

The first reform efforts therefore emerged just prior to independence to prepare the indigenous people for self rule. The attainment of independence generated immense development expectations and increased responsibilities that demanded changes in the administrative processes, culture, orientation, and capabilities. Both countries sought to reorient their systems to be responsive to the development needs of the people. As a

\footnotetext{
${ }^{3}$ Pollit C. and Geert Bouckaert. 2000. Public Management Reform: A Comparative Analysis. Oxford: Oxford Univesity Press, p. 1.
} 
result, the Africanization ${ }^{4}$ policy was introduced by which native Ugandans and Tanzanians replaced the Europeans and other foreigners, even in the face of a desperate lack of suitable local replacement and a continuing availability of trained foreign personnel. The Africanization policy was implemented in most former British colonies. Heady (2001) cites a Nigerian offering justification for the policy:

The decision was taken by our leaders that the British officials should be replaced, not because they hated or distrusted them, but because they felt that political independence was a sham unless you had also a great measure of administrative independence. You just could not be politically independent and remain administratively dependent, over a long period, without misunderstanding and tensions arising between the expatriate administrator and his indigenous political master. $^{5}$

In spite of the Africanization program and numerous subsequent reform efforts, efficiency, effectiveness, accountability, and responsiveness were not gained. If anything, the efforts proved inappropriate, inadequate, and uneconomic as the governments took on much more than what they could handle, while a dismal economic performance made worse the already dire administrative conditions. As a result, the post-independence administrative systems of both countries have been characterized by a bloated civil service, inadequate administrative capacity, limited financial and administrative resources, and a fragile political environment. The 1990s reform efforts were aimed at rectifying these problems. Individually, however, the administrative systems in the two states have faced and have been shaped by differing circumstances. While Uganda's

\footnotetext{
4 "Africanization" is a term used to refer to the process of indigenization of the civil service and other sectors of government.

${ }^{5}$ Heady, F. 2001. Public Administration: A Comparative Perspective. $6^{\text {th }}$ ed. New York: Marcel Dekker, Inc. p. 301.
} 
administrative system has been afflicted with many problematic colonial legacies and post-colonial failures common to most African countries, it has had a very deeply troubled and unique political and economic context that exacerbated the administrative pathologies.

Throughout the 1970s and 1980s, Uganda was characterized by immense political turmoil and economic collapse that negatively affected the performance, service delivery, management, and financial viability of the civil service. Idi Amin's military dictatorship coupled with Milton Obote's subsequent authoritarian rule destroyed most mechanisms of administrative, political, and financial accountability, thereby eliminating effective management, monitoring, and control within the civil service. When the National Resistance Movement (NRM) took over power in 1986, it found the country traumatized by civil war and state terror and the public service inefficient, demoralized, unresponsive, and corrupt. The NRM government with the support of the World Bank set up the Public Service Review and Reorganization Commission (PSRRC) in 1989, to examine the problems and to make appropriate recommendations. The Commission found that the Uganda Public Service was bloated in structure, inefficient, and generally a poor performer. The PSRRC made numerous recommendations on how to revamp the Service namely; 1) Rationalization of Government Structures and Functions including Decentralization of power to districts; 2) Reduction of the size of the Public Service; 3) Pay Reform through salary enhancement and monetization of non-cash benefits; 4) Personnel and Establishment control; 5) Improvement of Records Management; 6) 
Introduction of Results Oriented Management; and 7) Capacity Building. ${ }^{6}$ The overall objective of the public service reform program was to create a service that is small, motivated, accountable, efficient, effective, productive and responsive.

Tanzania on the other hand, has not endured critical political strife since independence and is considered one of the most stable nations in Africa. Instead, it is the country's ideological and economic predicament that put a strain on the civil service system. In a bid to hasten its development, the country upon attaining independence enacted the Arusha Declaration which explicitly called for an egalitarian society embodied in African socialism (Ujamaa). ${ }^{7}$ The country initiated a broad nationalization program of all firms, major commercial and financial institutions, and generally took charge of the economy's 'commanding heights.' In addition, the government "initiated a concerted program of collectivizing peasant farming and gave traditional agricultural cooperatives exclusive marketing rights, replacing private (mostly Asian) traders". These efforts seemed to generate initial benefits especially in social service delivery like provision of education, health care, and clean water. However, they also generated a huge public sector that was expanded even further by the many government parastatal organizations. As a result, the Tanzanian civil service over time became overstaffed, under-resourced, under-paid, inefficient, unresponsive, unmotivated, undisciplined, and ultimately unethical. By the mid 1980s, Tanzania's civil service, just like Uganda's, was

\footnotetext{
${ }^{6}$ The Public Service Review and Reorganzation Report, 1989, Kampala, Uganda.

${ }^{7}$ The Arusha Declaration was enacted in 1967 and its main goal was to increase the economic participation of indigenous Tanzanians.

${ }^{8}$ Kiragu, K. 1999. "Tanzania” In Adamolekun, L. Public Administration in Africa: Main Issues and Selected Country Studies. Boulder, CO: Westview Press, p. 329.
} 
characterized by limited capacity, a collapse in service provision, mal-administration, very low wages, corruption, and a general administrative decay.

In Tanzania, as in Uganda, since the colonial administration was instituted, attempts to reform the civil service have been many. The current study focuses on critically analyzing the reforms initiated in the country in 1993 with the support of the World Bank. The major components of this reform program include organization and efficiency reforms; rationalization of government employment; personnel control management; capacity building; and pay reform. ${ }^{9}$ In addition, great focus was placed on improving accountability and stamping out corruption. In both Uganda and Tanzania, the civil service reforms are being pursued not only for the sake of administrative efficiency, but also for democracy and good governance. In essence, the current civil service reforms in the two countries are linked to reforms in the economic and political spheres. Since the civil service reform initiatives were implemented in the early 1990s, a considerable number of reports, documents, articles, and books have been published. Many of them have been clarifying and enlightening, yet, they have at the same time fallen short of offering an in-depth critical analysis of the reform programs. The lack of critical analysis can be attributed to the fact that many of the reports and documents have been commissioned by the governments, by the implementers of the reform programs, and by the financiers of the programs, namely the World Bank (WB) and International Monetary Fund (IMF). Some of the publications have quite enthusiastically applauded the reform efforts. Others have been quite prescriptive, while some have shown a lack of balanced

\footnotetext{
${ }^{9}$ President's Office - Civil Service Department. 1999. Civil Service Reform Programme: Implementation Status Report (1993 - 1999). Dar es Salaam.
} 
critical analysis. Further, most of the studies have focused on one country and rarely been comparative. $^{10}$

The current study aims to undertake an in-depth empirical comparative analysis of the reform programs in Uganda and Tanzania. It offers a single integrated work that analyses the development of the civil services systems, and the political and economic context that shaped this development. It addresses what accounts for success of the reforms in one country and failure in the other. The conceptual stance of this study is in agreement with Pollitt and Bouckaert (2000:2) that "management changes in the public sector cannot be satisfactorily understood as some set of free-floating, generic phenomena. Instead, they require to be interpreted as one element in a broader shift in the pattern of political problems and responses. In short, public management is always part of the broader agenda of public governance."

\subsection{OBJECTIVES OF THE STUDY}

According to Shepherd (2003), "civil service reform has proven among the most difficult of developmental reforms to sustain, and there is little evidence that nationally or donor-inspired reform efforts have met with much success." ${ }^{11}$ The major objective of this study is to critically analyze the development and outcomes of the civil service

\footnotetext{
${ }^{10}$ The exception is the study by Clarke, J. and David Wood. 2001. "New Public Management and Development: The case of Public Service Reform in Tanzania and Uganda." In McCourt, W. and Martin Minogue (ed) The Internationalization of Public Management: Reinventing the Third World State. Cheltenham, UK: Edward Elgar.

${ }^{11}$ Shepherd, G. 2003. "Civil Service Reform in Developing Countries: Why Is It Going Badly? A Paper Presented at the $11^{\text {th }}$ International Anti-Corruption Conference held in Seoul, Republic of Korea, 25-28 May 2003, p. 2.
} 
reform programs instituted in Uganda and Tanzania since 1991 and 1993 respectively so that knowledge about the performance of the programs can be further enhanced. This objective is undertaken by exploring the civil servants' perceptions of the reform program. The study aimed at qualitatively getting their understanding, interpretation, and subjective experiences of the reform. It is important to know what changes if any, have resulted from the reforms, why, and the implication of such changes. The specific objectives of the study are:

1. to assess whether the size of the civil service systems in both countries have been reduced and the pay structures reformed

2. to assess whether capacity has been built in both countries' civil service systems

3. to analyze whether ethics and accountability have been enhanced since the reform programs were initiated

4. to determine what accounts for the differences and similarities between the CS reform programs in Uganda and Tanzania and;

5. to suggest ways in which the civil service reform programs may be improved to keep them on course.

Over all, the study aims at making a theoretical and empirical contribution to better understand the linkages among civil service reform, new public management, and governance.

\subsection{THE STUDY FOCUS}

The present study focuses on four major aspects of the reform programs implemented in the two countries namely; (i) the reduction of the size of the public 
service, (ii) pay reform, (iii) capacity building, and (iv), ethics and accountability. The rationale for focusing on the above four aspects is hinged on the fact that they were implemented first. Clarke and Wood (2007) assert that "Initially both countries gave priority to reducing and controlling numbers in order to release resources for improving salaries and enhancing services." ${ }^{\prime 2}$ They found that between 1990 and 1995, staff numbers had fallen by 23 percent and 55 percent, while average salaries had increased by 300 percent and 75 percent for Tanzania and Uganda respectively. But while their study focused on the years 1990-97, this study extends the analysis to 2006 and establishes whether that trend has persisted.

The research employs a case study method studying four government Ministries. Those chosen are the Ministry of Public Service (MPS), Ministry of Education (MOE), the Ministry of Finance (MOF), and the Ministry of Local Government (MOLG) in both countries. The goal here is to undertake a detailed study of these ministries so that, based on the findings, generalization can be made. Rosenbloom (1995) puts it succinctly when he asserts that, "Case studies of the implementation of reforms can potentially tell public managers what to do and what to avoid; what works and what does not in specific circumstances. They can improve understanding of the changes that are under way. Cases may also help the field to frame concepts, theories and research in ways that advance systematic knowledge about public administration."13

\footnotetext{
${ }^{12}$ Clarke, J. and David Wood. 2001. Ibid, p. 71.

${ }^{13}$ Rosenbloom, D. H. 1995. "The Use of Case Studies in Public Administration Education in the USA." Journal of Management History, Vol. 1, No. 1, pp. 33-46.
} 
The Ministries of Public Service have been selected because they are in charge of implementation of the reform programs. The Ministries of Education have been purposively selected for examination because they were cited as the most bloated government departments infested with "ghost" workers, drunkards, and the aged. The Ministries of Finance have been purposively selected because they are the ones in charge of revenue collection and expenditure. And the Ministries of Local Government have been selected because they so far represent "successful" implementation of the reform program. ${ }^{14}$ It is therefore believed that the three ministries will give the best picture of what is happening and the outcomes so far generated by the reform programs.

\subsection{RESEARCH QUESTIONS}

This study examines the following major question and sub-questions:

Have the civil service reform programs implemented in Uganda and Tanzania generated a small, motivated, efficient, effective, and accountable civil service as originally envisaged? If so why? If not, why not?

Sub-questions

\footnotetext{
${ }^{14}$ See Kjaer Anne Mette. 2004. "Old Brooms can Sweep too!: An overview of Rulers and Public Sector Reforms in Uganda, Tanzania and Kenya." Journal of Modern African Studies, Vol. 42, No. 3, pp. 389413. Clarke, J. and David Wood. 2001. "New Public Management and Development: the Case of Public Service Reform in Tanzania and Uganda." In McCourt, W. and Martin Minogue. The Internationalization of Public Management: Reinventing the Third World State. Cheltenham, U.K: Edward Elgar. Olowu, D. and Wunsch, J. S. 2004. Local Governance in Africa: The Challenge of Democratic Decentralization. Boulder, CO: Lynne Rienner Publishers. Nsibambi A. (Ed.) 1998. Decentralization and Civil Society in Uganda: The Quest for Good Governance. Kampala: Fountain Publishers. Wunsch, J. S. and Ottemoeller, D. 2004. "Uganda: Multiple Levels of Local Governance." In Olowu, D. and Wunsch, J. S. Local Governance in Africa: The Challenge of Democratic Decentralization. Boulder, CO: Lynne Rienner Publishers.
} 
1. What explains the inability of the Ugandan and Tanzanian civil service to comply with western bureaucratic standards that were supposedly left in place at independence?

2. How have the sizes of the civil service systems in the two countries changed since the program was initiated? What explains the changes?

3. Has the salary structure changed? How and in what areas are the changes manifest?

4. What capabilities have been developed or diminished since the reform was initiated?

5. Have the reform programs led to enhanced ethics and accountability?

6. Compared to the context before the reform programs were initiated, are the Uganda and Tanzanian civil services better performers? What are the indicators? and finally,

7. How can both the similarities and the differences between what has happened in Uganda as compared with what happened in Tanzania be explained?

The above questions were selected in order to get an in-depth description of what the civil servants felt about the reform program, hear them describe what it is like to be working during the reform, and to get their perceptions about changes they have seen. Ultimately, the study shows whether the reforms have succeeded or not, and offers reasons why; and provides suggestions for improving implementation.

\subsection{SIGNIFICANCE OF THE STUDY}

The current study provides a unique analysis of administrative reforms by situating the CS reforms in Uganda and Tanzania in a pre-and post-colonial historical 
perspective. Existing studies on administrative reform in developing countries base the analysis on Structural Adjustment Programs and ignore the influence of the historical context. The present study shows that in order to grasp the need for, and the performance of, the civil service reforms in the two countries, it is important to understand their colonial, economic, and political developments.

There are rather a few systematic and empirical comparative administrative reform studies that seek to answer the question of why reforms succeed or fail in developing countries. The study aims to fill that gap. It does so in a distinctive manner by providing an in-depth empirical analysis of the CSRP in the two countries, a first of its kind. Therefore, the study generates new literature and fills a gap in comparative administration studies.

\subsection{OUTLINE OF THE CHAPTERS}

Chapter one has offered a background to the study and research problem. Administrative reform is a complex endeavor and determining success is still a matter of contention. The objectives of the study were described, and the main research question and subsidiary questions were presented. Chapter one offered the justification for the study focus, and described why the study is significant.

Chapter two offers a review of the current literature on administrative reforms in developed and developing countries. A definition of the term 'administrative reform' is offered, and a historical analysis of administrative reform is addressed. Chapter two discusses the bureaucracy and administrative reform and situates the reforms in Uganda and Tanzania within the context of failed bureaucracies. The relationship between 
administrative reform and governance is explored. It is shown that prior discourse has not adequately discerned the linkage between the two concepts. The current study generates new data by showing that administrative reforms in the two countries are part of a wider quest for good governance.

Chapter three describes the methodology utilized in the study. It shows that a qualitative methodology was utilized in collecting, analyzing, and interpreting the data. It shows that primary data were collected through face to face interviews with subjects that were selected purposively and augmented by snowball sampling. The chapter addresses other sources of data among them official documents, government reports, news papers, and on-line sources. Chapter three also addresses validity and reliability.

Chapter four offers a historical account of bureaucratic development in Uganda and Tanzania. It describes the nature of the administrative systems that pertained in the pre-colonial period and how they were altered and developed by colonialism. A discussion of the colonial administrative system is offered and its effect on the postindependence civil service systems is addressed. Chapter four shows that contemporary civil service systems in the two countries have their roots in the colonial administrative system.

Chapter five describes the political and economic history of Uganda and Tanzania. It explores the effects of political instability and economic disequilibrium on the civil service in Uganda. The discussion also covers the political and economic developments in post-independence Tanzania. Focus is placed on the effects of the adoption of African Socialism enshrined in the Arusha Declaration. Chapter five shows 
that the quest for civil service reform in the two countries is best understood when analyzed within the political-economic historical context.

Chapter six presents and discusses the results based for Uganda. The analysis covers the four major aspects of the study. The findings show that the size of the civil service was reduced, salary was increased albeit unevenly, capacity building mechanism were put in place, and attempts to enhance ethics and accountability were made. The analysis shows that implementation of the four aspects of the reform followed a similar trajectory. Initial considerable success was attained, only to be undermined by political considerations. Chapter six concludes that while size reduction has generally been achieved, in spite of salary raises pay reform has not attained its goal. Capacity building is precarious because it is still difficult to hire and retain quality staff, and the enhancement of ethics and accountability is far from becoming reality. The study contends that the reform has been derailed by poor implementation strategies and gradual lack of political will and political legitimacy.

Chapter seven presents and discusses the results based on the data on Tanzania. The analysis focuses on the reduction of the size of the civil service, pay reform, capacity building, and ethics and accountability. The findings show that although the reform process started rather at a slow pace, great strides have been made and the program is currently vibrant, consistent, and steady. The size of the civil service has been reduced and a pay strategy to enhance salary has been formulated and put into effect. However, it was found that very little progress has been made in capacity building while ethics and accountability have been enhanced. Overall, the reform has generated considerable 
success. The study contends that the major reasons for the success are viable reform strategies and strong political legitimacy.

Chapter eight addresses what accounts for the differences and similarities in the reform trajectories of the two countries. It is argued that the nature of the political leadership, availability of viable political institutions, and the role of international donors account for the differences in the implementation of the CSRP trajectories of the two countries.

Chapter nine offers the conclusion and recommendations for future research. The main question of the study; whether the civil service reform programs in the two countries have generated small, motivated, efficient, effective, and accountable civil services is addressed. Chapter nine offers suggestions to improve implementation of the reforms, and suggests areas for further research. 


\section{CHAPTER 2: LITERATURE REVIEW}

\section{1 INTRODUCTION}

Chapter two reviews the literature that is most relevant to the research questions raised in the study. A definition of the term 'administrative reform' is offered and the numerous efforts at administrative reform initiated by both the developed and the developing world, and the different forms these efforts take are addressed. The goal here is to show how varied administrative reforms are, and how the measurement of success depends on the context. The chapter offers an analysis of the development of the bureaucratic paradigm and illustrates the linkages between the bureaucracy and administrative reform. I contend that the reform programs in Uganda and Tanzania are a result of failure to adhere to the traditional weberian bureaucratic norms. A review of the linkage between administrative reform and governance, and the linkage between the New Public Management and administrative reform is offered. Current literature does not discern the linkage among the three concepts. The current review fills that gap by situating the reforms in Uganda and Tanzania within the governance paradigm by showing that the reforms are not only geared towards efficiency in performance, but good governance and poverty eradication.

\subsection{WHAT IS ADMINISTRATIVE REFORM?}

The bureaucratic structure, principles, and values of the Ugandan and Tanzanian civil service systems are rooted in the western bureaucratic systems that were transferred into the two countries and into Africa, in general, in the early twentieth century. Correspondingly, the formal political institutions, principles, and processes that were 
introduced in the two countries at independence were largely a duplication of their former colonial masters' systems. Indeed, at independence, Uganda was bestowed a Westminster model of government with a prime minister as the head of government and a traditional King as a ceremonial head. Not surprisingly, however, soon after independence, the local cultural and socio-political factors exposed the British-derived administrative and political systems to tremendous challenges that resulted in radical changes in the western bureaucratic and political standards. It can therefore be asserted that the Ugandan and Tanzanian administrative and political systems were never complete replicas of their colonial masters' systems. Indeed, the quest for the current administrative reforms appears to be a second chance at adopting western administrative, bureaucratic, and political ideals. Yet, while the goal is to adopt western, so called "efficient and effective" administrative systems, it should be kept in mind that these western systems have themselves been undergoing programs of reform.

Administrative reform, also sometimes known as public management reform, is not new. Since the reforms of the early $19^{\text {th }}$ century, it has been argued that administrative reform engenders cheaper, more efficient government, facilitates the production of high-quality services and more effective programs, frees managers to manage, and enhances ethics, accountability and transparency in government (Caiden, 1991). Yet, in spite of such accolades, governments seem to implement one reform after another, signifying that such efforts do not always attain their goals and objectives. Studying the reform programs in Uganda and Tanzania becomes imperative in order to find out whether the reform efforts have attained their goals and objectives. In any case, while it may be that some reforms in some places do attain their aims, administrative 
reforms are peculiar to each country depending on the local context, priorities of politicians, administrative elite, and civil society.

The term "administrative reform" has enjoyed great usage in public administration for quite some time. As such, it is variously defined. According to Caiden (1991), it is the "induced systemic improvement of public sector operational performance. ${ }^{, 15}$ In his view, administrative reform aims at assessing government performance and predicting the general public's expectations of government. He argues that administrative reforms are needed to adapt government to the constantly changing needs of society and to enable public administration to reshape society. He aptly views the process of reform as "visionary, radical, political, risky, contrived, planned, artificial, opposed, time-consuming, problematic, elusive - and more." ${ }^{.16}$ Indeed administrative reform is a complex phenomenon whose results are not always predictable and one that is often viewed as a means to an end, rather than an end in itself.

Pollit and Bouckaert (2000) define administrative reform as "deliberate changes to the structures and processes of public sector organizations with the objective of getting them (in some sense) to run better." ${ }^{17}$ In their view, reform efforts potentially serve multiple ends among them making savings in public expenditure, improving the quality of public services, making the operations of government more efficient and increasing the chances that the policies which are chosen and implemented will be effective. Pollit and

\footnotetext{
${ }^{15}$ Caiden, E. G. 1991. Administrative Reform Comes of Age. New York: Walter de Gruyter. p. 1.

${ }^{16}$ Caiden, E. G. 1991, Ibid, p. 31.

${ }^{17}$ Pollit, C. and Geert Bouckaert. 2000. Ibid, p. 8.
} 
Bouckaert assert that the reform efforts might also generate "symbolic and legitimacy benefits." They elaborate that this is particularly common with political leaders. "For politicians, these benefits consist partly of being seen to be doing something. Announcing reforms, criticizing bureaucracy, praising new management techniques, promising improved services for the future, restructuring ministries and agencies - all these activities help attract favorable attention to the politicians who espouse them." ${ }^{, 18}$ Yet, the two offer a word of caution to those who believe that reforms solve all administrative problems. In their view evidence abounds that indicates that reforms can fail to attain their goals and objectives. "They may fail to produce claimed benefits. They may even generate perverse effects that render the relevant administrative processes worse....than they were previously." 19

Haggard (1997) conceives of administrative reform as "a process of re-writing the contract between elected politicians and bureaucratic officials. ${ }^{.20} \mathrm{He}$ views administrative reform as a political endeavor in terms of the political control of the bureaucracy and bureaucratic politics theory. His views are in stark contrast with Woodrow Wilson's and Frank Goodnow's call for a politics/administration dichotomy. Indeed, in many developing countries, reforms are engineered by politicians albeit with a huge external push from the international financial institutions like the IMF and World Bank. In her recent study of public sector reforms in Uganda, Tanzania and Kenya, Anne

\footnotetext{
${ }^{18}$ Pollit, C. and Geert Bouckaert. 2000. Op Cit , p. 6.

${ }^{19}$ Ibid.

${ }^{20}$ Haggard, S. 1997. "Reform of the State in Latin America." In Burki, S. J. and Perry Guillermo eds. Development in Latin America and the Caribbean. Washington, D. C.: World Bank.
} 
Metter Kjaer (2004) found that the country's political leaders played a critical role in garnering support for the reforms and in propping them forward. Similarly, in their recent study of administrative reforms in ten developed countries, Pollit and Bouckaert (2000) found the reform process required "the acquiescence, and more usually the active support of, leading politicians, particularly presidents, prime ministers and ministers of finance." 21 They also found that alongside executive politicians, senior civil servants were equally crucial actors in the reform program.

Although administrative reform is not a new phenomenon, contemporary reform efforts especially starting since the 1980 s are quite different from those in the $19^{\text {th }}$ century. As Pollit and Bouckaert (2000) assert, the contemporary reform efforts are "distinguished by an international character and a degree of political salience which marks them out from the more parochial or technical changes of the preceding quartercentury." 22

Civil service reform has been vigorously pursued by both the developed and developing countries for quite some time. The last two decades have witnessed numerous efforts at emulating private sector managerial and organizational entrepreneurial innovations by public organizations. The efforts are a result of the general poor performance and in particular the failure of public organizations to deliver services effectively and efficiently. To eliminate these difficulties, public organizations have embraced administrative reforms and are aggressively seeking both administrative and

\footnotetext{
${ }^{21}$ Pollit, C. Geert Bouckaert. 2000. Ibid, p. 19.

${ }^{22}$ Pollit, C. Geert Bouckaert. 2000. Ibid, p. 24.
} 
structural innovations. Most of them rely on market-style practices to root out the pathologies of bureaucracy. The quest for the application of entrepreneurial strategies to reduce expenditure, enhance revenue, and improve customer service is in line with market-style practices. Public organizations' reform efforts aim at the pursuit of innovative ideas and exploitation of opportunities for performance enhancement. The pursuit of civil service reform efforts calls for entrepreneurial-like and market-like changes. Public organizations are increasingly seeking innovative ways to improve performance and service delivery. Many public organizations have adopted new leadership and techniques, changed organizational goals and priorities, and reorganized their structures. Leaders of public organizations realize the urgent need for innovation and are accepting change as an opportunity, not a threat. ${ }^{23}$

However, since the $1980 \mathrm{~s}$, commitment to restructure and modernize public services has reached new heights. In the developed world, public sector reform efforts that have taken the form of "privatization, marketization, managerialism, decentralization, and agencifiction",24 among others, have been labeled "re-engineering" of government, and "reinventing of government." In the developing countries, the reforms have manifested in the form of retrenchment, liberalization, decentralization, and privatization among others, and have been labeled "revamping" and "revitalization" and "restructuring" of the public service. Because the reforms being undertaken have

\footnotetext{
${ }^{23}$ Morris, M. H. and F. A. Jones, 1999. "Entrepreneurship in Established Organizations: The Case of the Public Sector.” Entrepreneurship: Theory and Practice, Vol. 24, No.1, pp. 71-86.

${ }^{24}$ Butcher, T. 2003. "Modernizing Civil Services: An Era of Reform.” In Butcher, T. and Andrew Massey. Modernizing Civil Services. Cheltenham, UK: Edward Elgar, p. 1.
} 
similarities, it has been asserted that contemporary public administration is witnessing a new "global paradigm.."25 There are various reasons why administrative reform has become a catchword in the contemporary public sector. According to Caiden (1991), the 1980s administrative reform efforts in the West "stemmed from the economic and financial tribulations confronting governments unable to pay for public sector expenditures without increasing taxation, borrowing and inflation, none of which were politically acceptable."${ }^{26}$ Pollit and Bouckaert (2000) cite Koning (1996) as propounding that "extensive welfare state tasks, reduced financial latitude, economic structural crises, and the internationalization of public matters have put state administrations under reform pressure. ${ }^{27}$ For their part, they offer various reasons for wide spread civil service reforms namely; to restrain public spending, lighten the bureaucratic burden and reshape social policies that can no longer be afforded; and because of an interplay of global economic forces, socio-economic change and the supply of new management ideas. ${ }^{28}$

Yet, reforms are marked by diversity. Countries have pursued different aspects of the reforms in differing degrees. According to Nunberg (1995) while referring to the developed world, country reform efforts can be viewed along a continuum of change between two poles of systemic transformation and incremental improvements. The United Kingdom, Australia, New Zealand and Sweden are positioned at the reformist end

\footnotetext{
${ }^{25}$ Hood, C. 1995. “Contemporary Public Management: A New Global Paradigm?” Public Policy and Administration, Vol. 10, No.2, pp. 104 -117.

${ }^{26}$ Caiden, E. G. 1991, Op Cit, pp. 4-5.

${ }^{27}$ Pollit, C. Geert Bouckaert. 2000. Ibid, p. 27.

${ }^{28}$ For a more detailed description see Pollit, C. Geert Bouckaert. 2000. Ibid, pp. 24-38.
} 
of the continuum while USA and Germany are at the incrementalist end. He asserts further that Canada, France and the Netherlands are located in the middle of the continuum. ${ }^{29}$ The position of the developing countries is less clear. In some countries like Botswana, major reforms have been effected while in others, like Kenya, the reform program has not been wholly embraced. Uganda and Tanzania started off with great reformist zeal, but have now relapsed into the incremental mode as shall be illustrated in the pages ahead.

In spite of the discrepancy in the place on the continuum a country occupies, it can generally be asserted that in all cases, "the long standing assumptions that public services should be organized according to bureaucratic principles, and delivered through a carrier bureaucracy serving governments of any political persuasion, have been seriously challenged. ${ }^{\prime 30}$ Bureaucratic dysfunctions have necessitated tremendous efforts at reversing the initially hailed bureaucratic characteristics like hierarchical structures for horizontal ones and deregulation for regulation among others. But while the developed countries have sought to "reshape rigid, hierarchical nineteenth century bureaucracies into more flexible, decentralized, client responsive organizations, ${ }^{, 31}$ the developing countries have been forced to grapple with not only the bureaucratic dysfunctions, but also cultural, economic, and political elements that have negatively shaped the functioning of the administrative state.

\footnotetext{
${ }^{29}$ Nunberg, B. 1995. "Managing the Civil Service: Reform Lessons from Advanced Industrial Countries." World Bank Discussion Paper No.204. Washington D.C: World Bank, p. 4.

${ }^{30}$ Butcher, T. 2003. Ibid p. 1.

${ }^{31}$ Nunberg, B. 1995. Ibid p. 4.
} 
Indeed, it would be a stretch to assert that the problems derailing effective performance of civil service systems in developing countries are similar to those being faced by the developed countries. According to Shepherd (2003), the civil services of the developed countries "enjoy merit selection, insulation from undue political influence, and to the extent possible - arrangements to promote the productivity of civil servants." In contrast, he asserts further that, "the civil services of the developing countries tend to be large, underpaid and politicized." In his view, "senior cadres lack professional depth and often fail to provide any chain of continuity in government over the longer term.",32 Indeed, in most developing countries, notably in Africa, public services are poorly delivered (in some instances rarely or never), corruption is rampant, morale and motivation of the workers are low, while resources and equipment are lacking.

While industrialized countries grappled with size of the service and wage bill, developing countries seemed to have lost control over the public service's overall functioning. For instance before the administrative reforms implemented in Ghana in the early 1990s, the state was unable to mobilize resources for funding essential expenditure; it could not even deliver basic health and education services (Bates and Krueger, 1993). In pre-reform Uganda, government employment continued to grow in spite of sluggish economic growth and the wage bill became the single largest item of public expenditure accounting for $60 \%$ of current revenues (World Bank, 1991). The World Bank has argued that the public service in developing countries is too big, costs too much, and does not

\footnotetext{
${ }^{32}$ Shepherd, G. 2003. "Civil Service Reform in Developing Countries: Why is it Going Badly?" Paper presented at the $11^{\text {th }}$ International Anti-Corruption Conference, 25-28 May 2003, Seoul, Republic of Korea, p. 2 .
} 
have the capacity to carry out its administrative roles. In such a set-up, even the most imaginative structural reform is likely to flounder if it is implemented by the public service. So at a minimum, the public service has to be invested with the capacity to implement, enforce, and regulate administrative reforms. Hence, "any reform has to start with reforming the reformer - the public service." ${ }^{, 33}$

In 1980s, the World Bank facilitated many developing countries to implement structural adjustment programs. In Uganda and Tanzania, the structural adjustment menu included devaluation of the currency, liberalization of the economy, privatization, decentralization, and civil service reform. These programs came as a response to fiscal constraints, and their primary concern was to reduce the size of the public service and the wage bill.

Studies undertaken by the WB assert that there has been a substantial impact in reduction of numbers of the civil service but that the impact is not as positive in respect of reduction in the wage bill. In a study undertaken in 1993, it was suggested that compensation payments were a sizable drain on the exchequer, and the payments were often higher than or at least equal to the budgetary gains from staff reduction measures. ${ }^{34}$ Such suggestions are validated by a study conducted by Das (1998) in Gambia, Ghana and Guinea. He found that the reduction in the public service numbers did not generate enough resources to pay for the increases in public service remuneration. Compensation

\footnotetext{
${ }^{33}$ Das, S. K. 1998. Civil Service Reform and Structural Adjustment. Oxford: Oxford University Press, p. xiv

${ }^{34}$ World Bank. 1993. A Governance Approach to Civil Service Reform in Sub-Saharan Africa. World Bank Technical Paper Number 225, Washington D.C.: World Bank, Africa Technical Department, p. 10.
} 
payments to the retrenched staff were a drain on the budget and were higher than or at least equal to the savings generated by reduction in numbers in the public service. He concluded that the overall impact of the reform programs was limited. ${ }^{35}$ From his point of view therefore, while there were some reductions in public service numbers, the fiscal and efficiency impact was negative. Das elaborates further that reduction in the wage bill, "either absolute or relative, did not materialize; and attempts to rectify distortions in the pay and employment structure by decompression of wages or rationalization of remuneration had only limited success". ${ }^{36}$ The World Bank re-echoes his woes; "the efficiency gains from the reform in the larger context are not visible. The reforms have resulted in a 'leaner' state but not in a 'meaner' state - a state which can competently formulate policy and implement programs, and deliver services." ${ }^{, 37}$ These findings make it critical to evaluate the reform programs in Uganda and Tanzania. It is important to know whether they have attained their objectives or not. On the basis of the findings, recommendations for changes and improvements will be made.

While studies show that the impact of administrative reform in the developing countries has been close to dismal, studies about the experience of some industrialized countries with civil service reform show it has been rewarding (Das, 1998; Light, 1999; Kettl et al, 1996; Kim et al, 1995). Das (1998) argues that the experience of the industrialized countries, where the reform program has been on-going for some time now,

\footnotetext{
${ }^{35}$ Das, S. K. 1998. Ibid p. 42.

${ }^{36}$ Das, S. K. 1998. Ibid p. 47.

${ }^{37}$ World Bank. 1994A. Managing the Civil Service: Reform Lessons from Advanced Industrialized Countries. World Bank Discussion Paper 252, Washington D.C.: The World Bank, p. 1.
} 
suggests that public service reform could bring about improvements if it is taken up as a part of comprehensive changes to the economy and the public sector as a whole. He asserts that cutback management yielded substantial gains. "In New Zealand, for example, the public service number was reduced from 88,000 to 36,000 . In the UK, there was a reduction of 22 per cent in the public service numbers between 1979 and 1989 . Japan managed to cut its public service by 5 per cent between 1986 and 1992."38 It can however be argued that such reforms may have generated some rewards because they are internally induced. In most developing countries like Uganda and Tanzania, administrative reforms are externally induced and externally funded. It should not be surprising therefore that the implementation context, may not be conducive to success.

However, while Light (1999) acknowledges the improvements made by the public service reform program in the USA, he argues that whether the true size of government has expanded or contracted depends almost entirely on how one sorts the dates and the data. He argues that the federal government may be turning back the clock on the number of civil servants, but it continues to need a sizeable shadow to accomplish its mission. "These employees may not show up in the public service head counts that allow presidents to claim that the era of big government is over, but they are essential nonetheless. ${ }^{, 39}$ Light makes a strong point. In practice, publicness and privateness are contingent, even slightly artificial categories. If head counts are to be used in measuring the true size of government, it only seems reasonable to count every head in the total. So

\footnotetext{
${ }^{38}$ Das, S. K. 1998. Ibid p. 219.

${ }^{39}$ Light, C. P. 1999. The True Size of Government. Washington, D.C.: The Brookings Institution Press, p. 3.
} 
far, no study has been undertaken in Uganda and Tanzania to determine the size of the public service both public and the shadow. The current study will fill that gap by illustrating whether the true size of the three Ministries as case studies of the public service, have reduced or not since the reform program was initiated.

From the above discussion, it is evident that administrative reform is in fashion and all countries, developed and developing alike, are aggressively pursuing it albeit with differing results. A look at the development of western bureaucratic ideals will help shed more light on the transformation of administrative systems and the persistent quest for administrative reform in developed and developing nations alike.

\subsection{THE BUREAUCRATIC PARADIGM, ADMINISTRATIVE REFORM, AND GOVERNANCE}

The origins of the term bureaucracy are not entirely clear. According to Heady (2001) while Western bureaucratic development can be traced back to the Roman Empire, it is believed that the term was first used in the $18^{\text {th }}$ century France as bureaucratie to signify the working of government and later in the $19^{\text {th }}$ century spread to Germany as burokratie and eventually entered the English vocabulary. ${ }^{40}$ It is also generally believed that the term became popularized in social science discourse by German sociologist Max Weber in his famous "Essays in sociology." Weber used the term to signify an 'ideal-type' organization with distinctive characteristics, specific structures, processes, and behavior. Weber identifies the following characteristics as

\footnotetext{
${ }^{40}$ Heady F. 2001.Public Administration: A Comparative Perspective. $6^{\text {th }}$ ed. New York: Marcel Dekker, p. 71.
} 
essential to the bureaucracy: fixed and official jurisdictional areas ordered by rules, laws, and regulations; hierarchical authority and a firmly ordered system of super- and subordination; division of labor based on functional specialization; management based upon written documents and impersonal rules; and a lifelong career structure based on merit and seniority. ${ }^{41}$

According to Max Weber, the bureaucracy is technically superior over any other form of organization. Such superiority comes from the fact that a bureaucratic organization can accomplish large-scale administrative tasks by systematically coordinating the work of many people. In his view, a "fully developed bureaucratic mechanism compares with other organizations exactly as does the machine with the nonmechanical modes of production." ${ }^{42} \mathrm{He}$ asserts further that "precision, speed, unambiguity, knowledge of the files, continuity, discretion, unity, strict subordination, reduction of friction and of material and personal costs - these are raised to the optimum point in the strictly bureaucratic administration, and especially in its monocratic form." ${ }^{43}$ He contrasts his bureaucratic organization with collegiate bodies and other forms of administration propounding that the latter's work generates "friction and delay and requires compromises between colliding interests and views." In his view, such forms of administration are less precise, detached from superiors and therefore are "less unified and slower." Max Weber believed that even when tasks were complicated, a trained and

\footnotetext{
${ }^{41}$ Weber, M. "Bureaucracy” In Shafritz, J. M., Albert C. Hyde, and Sandra J. Parkes. 2004. Classics of Public Administration (5 ${ }^{\text {th }}$ ed.) London: Thomson Wadsworth, pp. 50-51.

${ }^{42}$ Weber, M. "The Ideal Bureaucracy” In Dalby, T. M. and Michael, S. Werthman. 1971. Bureaucracy in Historical Perspective. London: Scott, Foresman, and Company, p. 14.

${ }^{43}$ Weber, M. 1971. Ibid
} 
paid bureaucracy would be better equipped, more precise, more superior than other forms of administration. A bureaucracy therefore is a formal organization that is "rational" in Weber's view, and free of patrimonial tendencies. Peter Blau offers a Weber-supporting definition when he asserts that the term bureaucracy "applies to organizing principles that are intended to achieve control and coordination of work in large organizations. ${ }^{, 44}$ In his view, a bureaucracy is an "organization that maximizes efficiency in administration or an institutionalized method of organized social conduct in the interests of administrative efficiency." ${ }^{45}$

It should however be noted that Max Weber was not oblivious to the potentially negative consequences of bureaucracy. He acknowledged that bureaucracies tend to monopolize information and keep knowledge and intentions secret, thereby denying those outside the organization capability to understand how decisions are arrived at. ${ }^{46} \mathrm{He}$ also acknowledged the permanency of bureaucratic organizations by asserting that "once it is fully established, bureaucracy is among those social structures which are the hardest to destroy. ${ }^{, 47}$ Indeed in contemporary organizations, personnel maybe replaced should they voluntarily choose to leave or otherwise, but the system, its processes and procedures do remain intact. Weber, in addition and lastly, recognized that bureaucracies are not decisive when it comes to democracy and may even work towards democracy's

\footnotetext{
${ }^{44}$ Blau P. M. and Marshall W. Meyer 1987 (3 ${ }^{\text {rd }}$ ed.) Bureaucracy in Modern Society. New York: McGrawHill Publishing Company, p. 3-4.

${ }^{45}$ Blau P. M. and Marshall W. Meyer. 1987. Ibid.

${ }^{46}$ Max Weber, 1971. Ibid.

${ }^{47}$ Weber, M. 1947. The Theory of Social and Economic Organization. Translated by Henderson, A. M. and Talcott Parsons. New York: Oxford University Press, pp. 228-229.
} 
detriment. This is a worry that has preoccupied many scholars of democracy and bureaucratic theory. Famous public administration scholar and former U.S president Woodrow Wilson "also worried considerably that the power of a large civil service organized according to bureaucratic principles would be inconsistent with democratic governance.",48

It is therefore not surprising that the conceptual definitions of the term bureaucracy since its popularization in the late nineteenth century, have been different and sometimes antagonistic. While some view the bureaucracy in terms of its capacity to generate desirable traits like efficiency, objectivity, precision, consistency, autonomy, and structural differentiation, ${ }^{49}$ others focus on the pathologies of bureaucracy like rigidity and inflexibility, inefficiency, red-tape, and bloatedness. ${ }^{50}$ According to Merton (1949), "the very elements which conduce toward efficiency in general produce inefficiency in specific instances." He asserts further that they "also lead to an overconcern with strict adherence to regulations which induces timidity, conservatism, and technicism." Morstein (1957) for his part argues that "the bureaucratic type of organization gives rise to certain tendencies that pervert its purpose. Some of its strength

\footnotetext{
${ }^{48}$ Blau, P. M. and Marshall W. Meyer. 1987. Op Cit, p. 4.

${ }^{49}$ See Friedrich, C. J. 1963. Man and his Government. New York: McGraw-Hill Book Company. See also Eisenstadt, S. N. 1959. "Bureaucracy, Bueaucratization and Debureaucratization." Administrative Science Quarterly Vol.4, No.4, pp. 302-320.

${ }^{50}$ See Merton, R. 1949. "Bureaucratic Structure and Personality.” In Social Theory and Social Structure. New York: Free Press Inc.
} 
- and in extreme cases all of it - is drained off constantly by vices that paradoxically spring from virtues. ${ }^{.51}$

Yet, in spite of the critical analysis it has received, the bureaucratic organization persists in all modern public service systems. Heady (2001) put it succinctly when he asserted that "there seems to be little doubt that a viable polity in the world today must have a public service that meets these criteria for a bureaucracy. The necessities of government operation require large-scale organization of a bureaucratic type, with a definite internal hierarchical arrangement, well-developed functional specialization, and qualification standards for membership in the bureaucracy." ${ }^{, 52}$ While this assertion carries heavy weight, however, bureaucratic dysfunctions have necessitated tremendous efforts at reversing the initially hailed bureaucratic characteristics like hierarchical structures for horizontal ones and deregulation for regulation among others.

\subsubsection{The Role of the Bureaucracy in Administrative Reform}

Most contemporary countries, developed and developing alike, rely on bureaucratically organized public service systems. The rampant reliance on bureaucratic administrative systems is attributed to the fact that modern-day nations are enormous in organizational set-up, size, and functions, hence the problems posed by large-scale administration tend to lead to bureaucratization. In much of the West, bureaucratic ideals

\footnotetext{
${ }^{51}$ Morstein, M. F. 1957. The Administrative State: An Introduction to Bureaucracy. Chicago: University of Chicago Press, pp.25-28; and Crozier, M. 1964. The Bureaucratic Phenomena. Chicago: University of Chicago Press.

${ }^{52}$ Heady, F. 2001. Ibid, p. 77.
} 
were embraced in the late $16^{\text {th }}$ through the $19^{\text {th }}$ centuries. In Western Europe, the drive towards bureaucratization was engineered by the need to administer armies and national government. In France for instance, the quest for the autonomous power led the Monarchy to create a 'dependent body' of 'functionaries' to carry out specific duties and responsibilities. ${ }^{53}$ With the collapse of feudalism, the monarchical king instituted administrative specialization with officers in charge of financial, legal and military matters.

Another example of western European bureaucratic development is the Prussian bureaucracy. Just like the French monarchy succession of feudal lords, war commissioners succeeded the traditional autonomous provincial governments in Prussia by the end of the $17^{\text {th }}$ century. A standing army necessitated administrative and financial viability with the latter only possible through an institutionalized system of taxation. It should however be noted that in both France and Prussia, monarchical control of the nascent bureaucracy generated favoritism and patronage as the monarchy relied more on landed aristocrats than on administrative bureaucrats.

In contrast, in the United States, the bureaucracy emerged to stamp out patrimonialism and patronage. According to Blau and Meyer (1987), "Bureaucratization, when it occurred, was intended to achieve more centralized control over special interests and corrupt bosses to effect political reforms, that is 'good government."' They assert further that "this meant, in practice, the reduction of the influence of big business and the

\footnotetext{
${ }^{53}$ Jacoby, H. 1973. The Bureaucratization of the World. Berkeley, CA: University of California Press, p.
} 14. 
defeat of old-fashioned bosses and of the "spoils system' that rewarded friends.",54 Bureaucratization in the U.S public service was geared towards the strict separation of public administration from politics. As shall be seen in chapter five, the lack of the politics/administration dichotomy is one of the reasons for administrative failure in Uganda and Tanzania. In his famous essay "The Study of Administration",55, Woodrow Wilson called for a public administrative system separated from politics. In his view, politics corrupts bureaucracy and impedes the process of democratic governance. The same point was reiterated by Goodnow (1900). ${ }^{56}$ Yet, for others, the demarcation between public administration and politics is a fallacy. According to Waldo (1948), "administration is politics" 57 and hence accordingly, all administrative actions are inherently political. Waldo's assertion about the fusion of politics and administration is highly applicable in developing countries like Uganda and Tanzania. Indeed, as shall be seen, it is this politics/administration fusion that led to many of the problems of bureaucratic degeneration and civil service decay.

In the U.S., bureaucratization of the administrative system emerged with the institutionalization of the merit system in the civil service administration heralded by the Pendleton Act of 1883. It is at this point that the first major administrative reforms were

\footnotetext{
${ }^{54}$ Blau P. M. and Marshall, W. Meyer. 1987. Op cit, p. 32.

${ }^{55}$ Woodrow, W. 1887. "The Study of Public Administration.” In Political Science Quarterly, Vol. 2 Reproduced in Shafritz, J. M. and Hyde, A. C. and Sandra J. Parkes. 2004. Classics of Public Administration. $5^{\text {th }}$ ed. Belmont, CA: Thomson Wadsworth.

${ }^{56}$ Goodnow, F. J. 1900. Politics and Administration: A Study in Government. In Shafritz, J. M., Albert C. Hyde, and Sandra J. Parkes. 2004. Classics of Public Administration (5 ${ }^{\text {th }}$ ed.) London: ThomsonWadsworth.

${ }^{57}$ Waldo, D. 1948. The Administrative State: A Study of the Political Theory of American Public Administration. New York: Holmes and Meier.
} 
instituted. The goal was to rationalize the government, curb the excesses of the already bureaucratized large corporations like railroads and put an end to the patronage-based spoils system in the civil service. The administrative reformers of this era not only aimed at efficiency and morality in civil service, but they also aimed at generating political change. To eliminate patronage administrative appointments, open competitive examinations were introduced as the basis of selection of public employees. In addition, efforts were made to depoliticize the public service. The Pendleton Act of 1883 aimed to create a public service system organized like a business with minimal political interference, assessment and coercion. It was urged that public servants' authority and legitimacy ought to flow from their professional and technical competence rather than their partisan affiliations. ${ }^{58}$

Patronage in politics and administration was not unique to the U.S, France, and Prussia or any country. Eighteenth century Britain suffered its fair share of the same. Prior to the $19^{\text {th }}$ century, politicians that occupied and carried out responsibilities of high offices were appointed by the monarchy. According to Jennings (1954), "They in turn appointed the inferior officers, secretaries, assistant secretaries, clerks, writers, excisemen, dockyard officials, and so on." He asserts further that "They could, if they pleased, appoint their relatives, friends, and political supporters. What is more, a new Minister could make a clean sweep by using the crown's power of dismissal and filling

\footnotetext{
${ }^{58}$ Rosenbloom, D. H. and Robert, S. Kravchuk. 2004. Public Administration: Understanding Management, Politics, and Law in the Public Sector. $6^{\text {th }}$ ed. New York: McGraw-Hill.
} 
the vacancies with his own men." 59 It was not until 1855 when the first British Civil Service Commission was established that merit was introduced in the administrative system. According to Jennings, the Commission "was authorized to grant certificates of competence to candidates for junior posts and to hold examinations for persons nominated by the department. ${ }^{, 60}$ Indeed, in much of the post 1900 West, bureaucratic appointments have been based on professional merit criteria like education, training, and expertise instead of patronage. In a bureaucratic civil service, employees are compensated for their services by way of a monthly salary rather than in the form of prebends while service delivery is based on impartiality, impersonality and unbiased provision. The bureaucracy in its rational form in addition, is supposed to ensure honesty and accountability. According to Max Weber, public resources and equipment must be separated from the private property of the individual officer.

Max Weber's rational bureaucracy calls on public officers to be loyal to their offices and the 'impersonal and functional purposes', rather than to patrons. In return, such officers enjoy security of tenure. In much of the post $19^{\text {th }}$ century West, and in many developing countries as well, tenure is based on the competence of public employees and not subject to political or partisan consideration. According to Weber, "where legal guarantees against arbitrary dismissal or transfer are developed, they merely serve to guarantee a strictly objective discharge of specific office duties from all personal

\footnotetext{
${ }^{59}$ Jennings, I. 1971. "The achievement of British Bureaucracy” In Dalby, M. T. and Michael S. Werthman. Bureaucracy in Historical Perspective. London: Scott, Foresman and Company, pp. 24-25.

${ }^{60}$ Jennings, I. 1971. Ibid, p. 25.
} 
considerations. ${ }^{.61}$ It can therefore be argued that the $19^{\text {th }}$ century administrative reforms aimed at shaping a public service bureaucracy based on professionalism and autonomy from partisan politics. At this point, bureaucratization of the public service was the goal of administrative reform.

In much of the developing world, a semblance of bureaucratic ideals was planted by the colonial masters during colonialism. Notably, the post $19^{\text {th }}$ century western bureaucratic system was introduced in most of the colonies, and Uganda and Tanzania were no exceptions. Yet, because of differing contexts political, economic, and cultural, civil service systems in neither country adhered to western weberian bureaucratic ideals as shall be illustrated further in due course. Indeed, in most of Africa, the dichotomy between the civil service and politics has been lacking thereby fostering rampant patronage with public officials serving their own interests and those of their kin rather than those of the public, and utilizing public monies and equipment as personal property. It is partly because of this state of affairs that African states have had their development goals derailed. The current drive for administrative reform holds that replacing patronage systems for state officials by a professional, well trained and well paid bureaucracy is critical for African states to pursue development.

It should however be noted that Uganda and Tanzania do have entrenched centralized rules and procedures. Polidano (2001) points out quite correctly that "The problem in many developing countries is not absence of centralized rules and procedures. Rules and procedures are there aplenty, with all the disadvantages that adherents of the

\footnotetext{
${ }^{61}$ Weber, M. "Bureaucracy" Reprinted in Shafritz et al, 2004. Classics of Public Administration. Belmont, CA: Thomson Wadsworth.
} 
new public management would point to - rigidity, delays, duplication, bottlenecks, and so on....Centralization is no panacea for governments in developing countries." ${ }^{\circ 2}$ Indeed, while bureaucratic centralization and formal rules and regulations abound in both countries, those who are keen to get around the rules for wrong and often self-interest reasons are able to somehow do so, while committed and ardent managers find themselves snarled in red tape. The cultural and political practices in both countries and in Africa generally are not conducive to the fruitful usage of the Weberian bureaucratic model because rules and regulations are easily "bent" in a patrimonial manner. Commenting on bureaucratic management in Africa, Leonard (1987) asserted that "Africans are unusual among the world's elites in the extent of their patronage obligation to the poorer people and the strength of the moral pressures they fulfill. For these reasons, and for selfish ones that are far more universal, state organizations in Africa are extensively used to pursue informal, personal goals of their managers rather than collectives ones that are formally proclaimed." ${ }^{, 63}$ In Leonard's view, Africa's managerial values are at crossroads with those of the Western countries and the problem that most afflicts African bureaucracies is "bureaucratic hygiene."64

\footnotetext{
${ }^{62}$ Polidano, C. 2001. "Administrative Reform in Core Civil Services: Application and Applicability of the New Public Management." In McCourt W. and Martin Minogue. The Internationalization of Public Management: Reinventing the Third World State. Cheltnham, UK: Edward Elgar.

${ }^{63}$ Leonard, D. K. 1987. “The Political Realities of African Management.” In World Development, Vol. 15, No. 7, p. 901.

${ }^{64}$ Leonard (1987) asserts that lack of "bureaucratic hygiene" entails failures of systems of accounting, auditing, procurement, contract compliance, and personnel management. He asserts further that while such elements were introduced in African in the colonial and post-colonial era, they were not entrenched but rather have been on the decline.
} 
It can be argued that the relationship between bureaucracy and administrative reform is a paradoxical one. On one hand, the $19^{\text {th }}$ century public administration reformers relied on the introduction of bureaucratic ideals as a way of engendering efficiency, professionalism and better civil service performance. Yet, the twentieth century reformers and NPM agitators, believe that the bureaucracy has outlived its usefulness and is at odds with human needs, societal needs and even organizational performance needs, and aim at altering most of its basic ideals like strict adherence to rules, hierarchy, and formalism. Most of these called-for changes are enshrined in what is has come to be known as New Public Management (NPM). Yet, while western bureaucracies are searching for ways to become more entrepreneurial and less constrained by bureaucratic red tape, many governments in developing countries like Uganda and Tanzania face a more complicated challenge. One of the major problems is how to create the Weberian legal-rational directed bureaucracy while at the same time embracing the demands for good governance that call for debureaucratization. Indeed, the calls for bureaucratic change in Uganda and Tanzania seem to be an oxymoron. On one hand, evidence shows an existence of bureaucratic rules and regulations but further evidence shows that they are disregarded with impunity hence the calls for their abandonment since they do not serve any useful purpose. On the other hand, the CS reform program aims at strengthening those rules and regulations so that they may not be "bent".

Before proceeding with an analysis of NPM and administrative reform, it is important to discuss how bureaucracy relates to governance. In a somewhat similar 
paradoxical way discussed above, bureaucracy was supposed to generate good governance, yet it has also hindered its progress.

\subsubsection{Administrative Reform and Governance}

The term "governance" is relevant to this study because Uganda and Tanzania view civil service reform within the broader context of governance. Efficient, effective, responsive, and accountable services are viewed as prerequisites for good governance. The term governance gained unprecedented momentum in both its quest and usage in the nineteenth and twentieth centuries. Towards the end of the twentieth century however, the term governance more than ever gained prominent attention of donor agencies, social scientists, philanthropists, and civil society. Its popularity stems from the fact that it can be applied to a wide range of issues, relationships, and institutions involved in the process of governing and administration because it enlarges and better illustrates what actual governments should be focusing on. In addition, the demise of the cold war revitalized the usage of the term as donor agencies notably the WB and IMF and Western countries urged the countries of the former Soviet Union and the rest of the developing world to practice good governance in the form of economic and political reforms. However, the conceptualization of the term does not seem to be consistent. In a highly dynamic environment - politically, socially, economically, and culturally, the term means different things in different contexts thereby generating various definitions and meanings shown below. 
According to Jon Pierre (2000), "governance refers to sustaining co-ordination and coherence among a wide variety of actors with different purposes and objectives." Such actors may include political actors and institutions, interest groups, civil society, nongovernmental and transnational organizations. Jon Pierre's definition illustrates on one hand that the traditional state government has to cope with internal challenges and external challenges from the above actors, while on the other it illustrates that some of the functions previously the preserve of government maybe taken over by some of the above actors. The definition gives credence to the assertion made earlier that governance is broader than government. While Pierre's definition of governance is society-centric, Peters and Pierre (2000) offer a definition of the term that is more state-centric. Even as they concede that "governance relates to changing relationships between state and society and a growing reliance on less coercive policy instruments" they assert that "the state is still the centre of considerable political power" They therefore perceive governance as "processes in which the state plays a leading role, making priorities and defining objectives. ${ }^{\prime 66}$ This is in line with the notion of the role of the state as that of 'steering' society and the economy. Indeed, in Tanzania, attempts are being made to confine the civil service to the role of steering; contracting out of non-core functions is under way, and various executive agencies have been formed to perform the traditional roles of government.

\footnotetext{
${ }^{65}$ Pierre, J. 2000. Debating Governance: Authority, Steering, and Democracy. Oxford: Oxford University Press, pp. 3-4.

${ }^{66}$ Pierre, J. and Guy B. Peters. 2000. Governance, Politics, and the State. New York: St. Martin's Press, p. 12.
} 
Yet governance can be viewed as a response to the decline in state capabilities, notably its financial and service resources. It is the economic crisis that has forced the state to become less self-reliant and more inclined to operate through networks and other forms of public-private partnerships. In this context, the state aims at coordinating these public and private endeavors (negotiated social governance) and keeping them congruent. Hirst (2000) offers a more general definition of the term. He asserts that "governance can be generally defined as the means by which an activity or ensemble of activities is controlled or directed, such that it delivers an acceptable range of outcomes according to some established standard.",67

The World Bank (1993) defines governance as the method through which power is exercised in the management of a country's political, economic, and social resources for development. ${ }^{68}$ While the WB has for a long time focused on stabilization and state reforms that overwhelmingly focused on civil service retrenchment and privatization, the early 1990s saw a change of focus. The Bank came to realize that most of the crises in developing countries are of a governance nature. Hence, the contemporary adjustment package emphasizes issues like transparency, accountability and judicial reform, issues that are believed to enhance governance and civil service performance. In this context, the WB introduced a new way of looking at governance; good governance.

According to the World Bank (1993), there are three major categories of good governance; systemic, political, and administrative. Systemic governance is broader than

\footnotetext{
${ }^{67}$ Hirst, P. 2000. "Democracy and Governance" in Pierre, J. (Ed.) Debating Governance: Authority, Steering, and Democracy. Oxford: Oxford University Press, p. 24.

${ }^{68}$ World Bank. 1993. Governance. Washington DC: The World Bank.
} 
government and entails the distribution of both internal and external political and economic power. Political governance is attained when a state enjoys both legitimacy and authority derived from a democratic mandate. Administrative governance refers to efficiency, openness, accountability and audited public service. ${ }^{69}$ In the context of most developing countries, good governance signifies a governmental framework that functions in a responsible, accountable, and transparent manner. This governmental framework should also be based upon the principles of efficiency, legitimacy, and consensus. The CS reform programs being implemented in Uganda and Tanzania are being pursued under the broader pursuit of good governance.

The term governance has gained great usage in the contemporary administrative reform field. Many public administration theorists believe that the term governance is an organizing concept that guides administrators as administrative practices shift from the bureaucratic state to what Milward and Provan (1993) call the "hollow state"70 and what Osborne and Gaebler (1993) call "third-party government.",71 This view of government makes the connection between bureaucracy, administrative reform and governance. As civil service systems embark on administrative reforms geared at freeing the former of the pathologies of bureaucracy, governance becomes paramount as an avenue through which structures and practices that achieve accountability and equity, while at the same

\footnotetext{
${ }^{69}$ World Bank 1993. Ibid.

${ }^{70}$ For a more elaborate discussion see Milward, H. B. and Provan, K. G. 1993. "The Hollow State: Private Provision of Public Service." In Ingraham, H. and Smith, R. S. (Eds.). Public Policy for Democracy. Washington, D. C.: Brookings Institution Press.

${ }^{71}$ Osborne, D and Ted Gaebler 1993. Reinventing Government. Reading, Mass: Addison-Wesley Publishing Company.
} 
time providing government flexibility, responsiveness and participation can be created and harnessed. According to Minogue (2001), good governance reinforces the calls of NPM. In his view, "Good governance and new public management are regarded as mutually supportive reforms, with greater political and social accountability contributing to the realization of more efficient government.",72

Frederickson and Smith (2003), have a similar conception of the term. In their view, "Governance refers to the lateral and inter-institutional relations in administration in the context of the decline of sovereignty, the decreasing importance of jurisdictional borders, and a general institutional fragmentation."73 Frederickson and Smith assert further that with more emphasis on governance, "the administrative state is now less bureaucratic, less hierarchical, and less reliant on central authority to mandate action. Accountability for conducting the public's business is increasingly about performance rather than discharging a specific policy goal within the confines of the law."74 Frederickson and Smith make the relationship between bureaucracy, administrative reform and governance even more explicit. In their view, the quest for civil service reform is geared towards righting bureaucratic wrongs and governance helps achieve that goal.

\footnotetext{
${ }^{72}$ Minogue, M. 2001. "The Internationalization of New Public Management." In McCourt, W. and Martin Minogue. The Internationalization of New Public Management: Reinventing the Third world State. Cheltenham, UK: Edward Elgar, p. 6.

${ }^{73}$ Frederickson, H. G. and Kevin B. Smith. 2003. The Public Administration Theory Primer. Boulder, CO: Westview Press, p. 222.

${ }^{74}$ Frederickson, H. G. and Kevin B. Smith. 2003, Ibid, p. 208.
} 
In developing countries like Uganda and Tanzania, the relationship between governance and the civil service reform is very important given the donor pressure on public bureaucratic agencies to become leaner, more efficient, and responsive. In both countries, as part of the donor-driven structural adjustment programs, there have been attempts to reduce the role of the state in relation to the market, cut back the size of the civil service in both personnel numbers and real wages, enhance accountability, and improve managerial efficiency. The WB and IMF have pressured both countries to pursue good governance asserting that good governance entails sound public sector management (efficiency, effectiveness, and economy), accountability, exchange and free flow of information (transparency), and a legal framework for development (justice, respect for human rights and liberties). ${ }^{75}$ The 1989 World Bank report also called for similar changes. It asserts that "better governance requires political renewal. This means a concerted attack on corruption from the highest to the lowest level... strengthening accountability... ${ }^{76}$ Indeed, the CSRP in the two countries aim at strengthening accountability. However, in Uganda, attack on corruption at the highest level is lukewarm while in Tanzania, the highest level of political leadership is championing the fight against corruption.

Other donor agencies carry the same stance. The Department for International Development (1993), formerly the UK Overseas Development Administration (ODA) for instance also defines good governance by focusing on four major components namely

\footnotetext{
${ }^{75}$ World Bank. 1993. Governance. Ibid.

${ }^{76}$ World Bank. 1989. Sub-Saharan Africa: From Crisis to Sustainable Growth. Washington, D.C: The World Bank, p. 6.
} 
legitimacy (government should have the consent of the governed); accountability (ensuring transparency, being answerable for actions and media freedom); competence (effective policy making, implementation and service delivery); and respect for law and protection of human rights. ${ }^{77}$ In this context, governance goes hand in hand with administrative reforms focusing on bureaucratic performance including government efficacy, responsiveness, and ethics. Indeed the major goal of the civil service reform programs in both Uganda and Tanzania is to create a service that is small, motivated, accountable, efficient, effective, productive, and responsive.

It is the contention of my dissertation that governance in Uganda and Tanzania goes further to focus on poverty eradication. Recent literature has not made that connection. In both Uganda and Tanzania, the Poverty Eradication Action Plans (PEAP) emphasize that a functional public service system is critical to combating poverty and strengthening the access of the poor to public services. The study does indeed show that administrative reforms in Uganda and Tanzania focus on revamping, reinvigorating, and revitalizing the public service, so that performance can be enhanced and service delivery improved.

\subsection{NEW PUBLIC MANAGEMENT AND ADMINISTRATIVE REFORM}

New Public Management (NPM) is seen as a paradigm shift in public administration and has been in existence for approximately the last two decades. It is generally perceived as a global public management reform movement that redefines the

\footnotetext{
${ }^{77}$ ODA. 1993. Taking Account of Good Government. London: Overseas Development Administration.
} 
relationship between government and society. New public management is a general move away from traditional public administration to what has come to be known as the "new managerialism", "market-based public administration", and "entrepreneurial government." It is thought to have originated from Australia, New Zealand and the United Kingdom. Spurred by citizen dissatisfaction with government performance, bureaucratic red tape, endemic fiscal problems and seemingly successful restructuring in the private arena, calls for public sector reform, the abandonment of traditional public administration and reinventing government, became rampant. According to Hughes (1994), there are four major reasons why governments have questioned the viability of the traditional system to manage public services effectively;

1. In the late 1970s tax revenues declined and governments faced severe resource constraints and at the same time politically could not reduce services provided to the public. This meant the public service was asked to provide the same or increased services with reduced finance and fewer staff.

2. New governments such as those in Britain, Canada, New Zealand and Australia in the late 1970s and 1980s had their own detailed ideas on how to change the management of the public service and these ideas were generally similar.

3. There is an explicit link between restructuring economies and improving public sector management. Governments could not be seen to be asking the business community to improve competitively without being seen to improve its own apparatus, and

4. There was an intellectual climate conducive to a reduction in the public sector and/or to make it more efficient. ${ }^{78}$

Like other theorists disparaging the traditional administrative systems, Hughes is of the view that it was rigid and bureaucratic, myopic, and preoccupied with formalism.

\footnotetext{
${ }^{78}$ Hughes, O. E. 1994. Public Management and Administration: An Introduction. New York: St. Martin's Press, pp. 65-66.
} 
Many scholars and theorists as earlier illustrated have argued that the $19^{\text {th }}$ century traditional civil service is out of tune with the contemporary needs. In their popular book "Reinventing Government," Osborne and Gaebler (1993) assert that "the kind of governments that developed in the industrial era, with their sluggish centralized bureaucracies, their preoccupation with rules and regulations and their hierarchical chains of command, no longer work very well... Hierarchical, centralized bureaucracies ..... simply do not function well in the rapidly changing, information-rich knowledgeintensive society and economy of the 1990s." ${ }^{, 79}$ In their view, the solutions lie in NPM, which calls on government to focus on achieving results rather than primarily conforming to procedures. It also calls on government to adopt market-like competition, innovations and entrepreneurial strategies. In order to be market-like, government and public administration generally is called upon to be customer-driven and rely on market-based mechanisms to deliver public services.

It can therefore be argued that NPM is inspired by economic and market theories and values that call for efficiency, effectiveness, economy, productivity, doing more with less, and focusing on the customer. According to Poladino (2001), the key components of NPM include "the deregulation of line management; the conversion of civil service departments into free-standing agencies or enterprises; performance-based accountability...; and competitive mechanisms such as contracting out and internal markets." $" 80$

\footnotetext{
${ }^{79}$ Osborne, D and Ted Gaebler 1993. Reinventing Government. Reading, Mass: Addison-Wesley Publishing Company, p. xix.

${ }^{80}$ Polidano, C. 2001, Op Cit, p. 44.
} 
According to Rosenbloom and Kravchuk, NPM calls on public administration to change its culture, and be "flexible, innovative, problem solving, entrepreneurial, and enterprising as opposed to rule-bound, process-oriented, and focused on inputs rather than results. ${ }^{\prime 81}$ New public management advocates charge that civil service has become so legalistic that it is too rigid to be effective and that political executives lack the flexibility to handle personnel in a productive way. Indeed the NPM views civil service bureaucracies as obsessed with procedure but relatively uninterested in achieving results. The major argument is that public service bureaucracies are tied up in red tape that they cannot respond efficiently to customers. Yet if the US case is considered, this is exactly what the $19^{\text {th }}$ century reformers sought. At the time, it was argued that fixed rules, however imperfect, are better than arbitrary power. New public management's contention that public administrators should be conceived as entrepreneurs, seeking opportunities to create private partnerships and serve customers has come under criticism. Denhardt and Denhardt argue that "this perspective of the public administrator is narrow, and is poorly suited to achieve democratic principles such as fairness, justice, participation, and the articulation of shared interest." $" 82$

In general how ever, many of the current administrative reforms, especially in the developed world are part of NPM. These include privatization, marketization and contracting out in which quasi markets are introduced in government agencies with independent providers encouraged to compete for contracts, deregulation,

\footnotetext{
${ }^{81}$ Rosenbloom, D. H. and Robert, S. kravchuk. 2004. Public Administration, Op cit, p. 24.

${ }^{82}$ Denhardt, J. V. and Denhardt, R. B. 2003. The New Public Service: Serving, not Steering. New York: M. E. Sharpe, p. 133.
} 
decentralization, and employee empowerment and performance measurement. It should however be noted that NPM has not been universally applied and even in the Western countries its benefits have not been easy to identify. According to Poladino et al. (1998), in Britain, Australia and New Zealand, countries with many years of successful NPMdriven reform, "much evidence on outcomes remains anecdotal and difficult to verify." While citing Walsh (1995), they argue that even though contracting out of public services to private operators has yielded savings in direct costs, it is not clear whether savings are sustainable in the long run, and if transaction costs are included in the savings reports.

Minogue et al. (1998) argue that its application is less so in the developing countries. McCourt et al. (2001) have similar views. Minogue (2001) argues that while examples of introduction of NPM reforms in developing and transitional countries abound, "empirical evaluations are thin on the ground." He asserts further that "Even where the reforms appear to be unmistakable, as in Malaysia, for example, we still need evidence of whether real changes in managerial practice have taken place, as opposed to the adoption of a few fashionable but meaningless labels." ${ }^{84}$ Indeed while many developing countries have attempted to initiate "western' administrative reforms like privatization, decentralization and contracting out, very few if any, have strictly abided by NPM ideals. Yet, it is also acknowledged that other non-NPM administrative reforms have not attained their goals and objectives either. Minogue (2001) puts it succinctly

\footnotetext{
${ }^{83}$ Poladino, C. David Hulme and Martin Minogue. 1998. "Conclusions: Looking Beyond the New Public Management." In Minogue, M., Charles Polidano, and David Hulme. Beyond the New Public Management: Changing Ideas and Practices in Governance. Chelterham, UK: Edward Elgar, p. 280.

${ }^{84}$ Minogue, M. 2001. 2001. “The Internationalization of New Public Management” Ibid, p. 9.
} 
when he asserts that "the problems of NPM reforms are not more serious than those of the non-NPM reforms." ${ }^{85}$ This study attempts to show whether Uganda and Tanzania have embraced the NPM ideals and what benefits if any, have arisen, while also critically assessing the outcomes of the mainstream CS reforms like capacity building and anticorruption measures.

\subsection{SUMMARY}

Chapter two has provided a review of the current literature on administrative reforms in both the developed and developing countries and shown how it is relevant to the study. A definition of the term 'administrative reform' was offered and the numerous efforts at administrative reform initiated by both the developed and the developing world, and the different forms these efforts take addressed. The chapter has offered an analysis of the development of the bureaucratic paradigm and illustrated the linkages between the bureaucracy and administrative reform. A review of the linkage between administrative reform and governance, and the linkage between the New Public Management and administrative reform was offered. The review in the present study contributes to current literature by situating the reforms in Uganda and Tanzania within the governance paradigm. It has been shown that the reforms are not only geared towards efficiency in performance, but good governance and poverty eradication.

\footnotetext{
${ }^{85}$ Ibid, p. 11.
} 


\section{CHAPTER 3: RESEARCH METHODOLOGY}

\subsection{INTRODUCTION}

In chapter three, a discussion of the methods and procedures that were utilized in gathering and analyzing data for the study is provided. I conducted primary data collection (the field work) for this study in Uganda and Tanzania in the summer of 2006 from May to August. Chapter three is divided into seven sections. The next section describes the objectives of the study and states the questions that guided the study. The third section describes the research design and shows that the qualitative methodology was utilized in collecting, analyzing, and interpreting the data. The fourth section focuses on data collection techniques, and shows that primary data were collected through face to face interviews with subjects who were selected purposively and augmented by snowball sampling, and presents other sources of data among them official documents, government reports, news papers, and on-line sources. Section five describes the data analysis processes, section six illustrates how validity and reliability were ensured, and section seven is the chapter summary.

\subsection{THE OBJECTIVES OF THE STUDY}

The major objective of this study was to critically analyze the development and outcomes of the civil service reform programs instituted in Uganda and Tanzania since the 1991 and 1993 respectively, so that knowledge about the performance of the programs can be further enhanced. The objective was attained by exploring the civil servants' perceptions of the reform program. The study aimed at qualitatively getting 
their understanding, interpretation, and subjective experiences of the reform. The specific objectives of the study were:

1. to assess whether the size of the civil service systems in both countries have been reduced and the pay structures reformed

2. to assess whether capacity has been built in both countries' civil service systems

3. to analyze whether ethics and accountability have been enhanced since the reform programs were initiated

4. to determine what accounts for the differences and similarities between the CS reform programs in Uganda and Tanzania and;

5. to suggest ways in which the civil service reform programs may be streamlined to keep them on course.

Over all, the study aimed at making a theoretical and empirical contribution to better understand the linkage between civil service reform, new public management, and governance.

In order to attain the above objectives, the study examined the following major question and sub-questions:

Have the civil service reform programs implemented in Uganda and Tanzania generated a small, motivated, efficient, effective, and accountable civil service as originally envisaged?

Sub-questions

1. What explains the inability of the Ugandan and Tanzanian civil service to comply with western bureaucratic standards that were supposedly left in place at independence? 
2. How have the sizes of the civil service systems in the two countries changed since the program was initiated? What explains the changes?

3. Has the salary structure changed? How and in what areas are the changes manifest?

4. What capabilities have been developed or diminished since the reform was initiated?

5. Have the reform programs led to enhanced ethics and accountability?

6. Compared to the context before the reform programs were initiated, are the Uganda and Tanzanian civil services better performers? What are the indicators? and finally,

7. How can both the similarities and the differences between what has happened in Uganda as compared with what happened in Tanzania be explained?

The above questions were selected in order to get an in-depth description of what the civil servants felt about the reform program, hear them describe what it is like to be working during the reform and what changes they have seen.

\subsection{RESEARCH DESIGN}

The current research study was conducted through a non-experimental, summative case study. According to Patton (2002), summative evaluation determines a program's effectiveness. He asserts that "Summative evaluations serve the purpose of rendering an overall judgment about the effectiveness of a program, policy, or product for 
the purpose of saying that the evaluand ${ }^{86}$ (thing being evaluated) is or is not effective and, therefore, should or should not be continued, and has or does not have the potential to being generalizable to other situations." ${ }^{87}$ Summative evaluations are typically undertaken on programs that have stabilized. The Civil Service Reform programs in Uganda and Tanzania have been in place for over ten years and so are ideal for evaluation.

The research employed a case study method focusing on an in-depth analysis of four ministries in each country namely the MPS, the MOE, the MOF, and the MOLG. According to Neuman (2000), in a case study, a researcher might intensively investigate one or two cases or compare a limited set of cases by focusing on several factors. Case studies aim at generating detailed, varied, and extensive descriptions of a program or policy. He asserts that the "researcher carefully selects one or a few key cases to illustrate an issue and analytically study it (or them) in detail." He agrees with Walton (1992) that "The logic of the case study is to demonstrate a causal argument about how general social forces shape and produce results in particular settings." ${ }^{\prime 88}$ According to Berg (2004), case studies "involve systematically gathering enough information about a particular person, social setting, event, or group to permit the researcher to effectively understand how the subject operates or functions." 89

\footnotetext{
${ }^{86}$ Emphasis in the original text.

${ }^{87}$ Patton, M. Q. 2002. Qualitative Research and Evaluation Methods. $3^{\text {rd }}$ ed. Thousand Oaks, CA: Sage Publications, Inc. p. 218.

${ }^{88}$ Neman, W. L. 2000. Social Research Methods: Qualitative and Quantitative Approaches. $4^{\text {th }}$ ed. Boston, MA: Allyn and Bacon, pp. 32-33.
} 
The case study methodological approach therefore is the most viable at gaining an in-depth understanding of the performance of the CSRP in Uganda and Tanzania. Berg (2004) asserts further that the use of case studies enables the researcher "to capture various nuances, patterns, and more latent elements that other research approaches might overlook." In his view, "Extremely rich, detailed and in-depth information characterize the type of information gathered in a case study." ${ }^{, 90}$ In reference to administrative reforms, Rosenbloom (1995) puts it succinctly when he asserts that, "Case studies of the implementation of reforms can potentially tell public managers what to do and what to avoid; what works and what does not in specific circumstances. They can improve understanding of the changes that are under way. Cases may also help the field to frame concepts, theories and research in ways that advance systematic knowledge about public administration." ${ }^{91}$ Schramm (1971) makes a similar point when he asserts that case studies "illuminate a decision or set of decisions: why they were taken, how they were implemented, and with what result.. ${ }^{, 92}$ In a naturalistic and context sensitive study, a case method helps in understanding the complexities of the reform program by gathering comprehensive, systematic, and in-depth information about the reform processes in the two countries. The present study provides a rich and detailed description and analysis of

\footnotetext{
${ }^{89}$ Berg, B. L. 2004. Qualitative Research Methods for the Social Sciences. Boston: Pearson Education Inc. p. 251.

${ }^{90}$ Berg, B. L. 2004. Ibid, p. 251.

${ }^{91}$ Rosenbloom, D. H. 1995. "The Use of Case Studies in Public Administration Education in the USA." Journal of Management History, Vol. 1, No. 1, pp. 33-46.

${ }^{92}$ Schramm, W. 1971. "Notes on Case Studies of Instructional Media Projects." Working Paper for the Academy of Educational Development. Washington, D.C, p. 6.
} 
the reform programs initiated in Uganda and Tanzania based on the perceptions of the civil servants in the two countries.

The research design employed qualitative methods of data collection. A qualitative methodology was used because the study sought to provide an in-depth description of the CSRP in Uganda and Tanzania, specifically implementation of four major aspects; staff reduction, pay reform and salary enhancement, capacity building, and ethics and accountability enhancement using the above mentioned ministries as case studies. Most studies that examine administrative reforms tend to be quantitative and statistical and not based on the perceptions of those involved in the reform process. Because so little is known about the perceptions of the staff and workers of the reform, it is appropriate to use a qualitative approach to explore the perceptions that the Ugandan and Tanzanian civil servants have about the reform program. Qualitative research is useful for examining the experience of participants without making judgments in advance as to what results one might find.

According to Strauss and Corbin (1998), qualitative research is "research that produces findings not arrived at by statistical procedures or other means of quantifications. It can refer to research about persons' lives, lived experiences, behaviors, emotions, and feelings as well as about organizational functioning, social movements, cultural phenomena, and interactions between nations." 93 In agreement with Strauss and Corbin, the present study offers a nonmathematical process of data analysis and interpretation, carried out for the purpose of discovering themes in raw data which

\footnotetext{
${ }^{93}$ Strauss, A. and Juliet Corbin. 1998. Basics of Qualitative Research: Techniques and Procedures for Developing Grounded Theory. Thousand Oaks, CA: Sage Publications, p. 11.
} 
themes are in turn used to offer a thick description and analysis of the civil service reform programs. Berg (2004) asserts that "qualitative procedures provide a means of accessing unquantifiable facts about the actual people researchers observe and talk to or people represented by their personal traces... As a result, qualitative techniques allow researchers to share in the understandings and perceptions of others and to explore how people structure and give meaning to their daily lives." ${ }^{94}$ A qualitative approach was favored because it permits a great in-depth inquiry into a selected issue with careful attention to detail, context, and nuance. Qualitative research is not constrained by predetermined analytical categories and so has the potential to generate a wealth of detailed data about a small number of cases. According to Patton (2002), "qualitative data in summative evaluations typically add depth, detail, ....and render insights from illuminative cases studies... "95 Ragin (1994) cautions that qualitative and case study research are not identical but adds that "almost all qualitative research seeks to construct representations based on in-depth, detailed knowledge of cases." 96

Neuman (2000) asserts that "Qualitative researchers emphasize the importance of social context for understanding the social world." He asserts further that such researchers "hold that the meaning of a social action or statement depends, in an important way, on the context in which it appears. ${ }^{.97}$ Indeed, the current study pays special attention to the context of the reform program implementation by critically

\footnotetext{
${ }^{94}$ Berg, B. L. 2004. Ibid, p. 7.

${ }^{95}$ Patton, M. Q. 2002. Ibid, p. 220.

${ }^{96}$ Ragin, C. 1994. Constructing Social Research. Thousand Oaks, CA: Pine Forge Press, p. 92.

${ }^{97}$ Neuman, W. L. 2000. Ibid, p. 146.
} 
analyzing the political, economic and administrative contexts prior to the reforms and the current context. The context under which a program is executed has great influence on the implementation and outcome of a program. As noted earlier, the CS systems in both countries took, over time, differing paths and were affected by differing political, economic and social issues and hence evolved differently. A qualitative study helps to shed light on the impact of the contexts on the reform program.

The current qualitative study was based on the interpretive/constructivist paradigm. The basic assumptions guiding the interpretive/constructivist paradigm are that knowledge is socially constructed by people active in the research process, and that researchers should attempt to understand the "complex world of lived experience from the point of view of those who live it" ${ }^{\prime 98}$ Therefore, the qualitative research perspective utilized in the study is phenomenology. Phenomenological research emphasizes the individual's subjective experience. According to Patton (2002), "the term phenomenography (emphasis his) was coined by Ulrich Sonnemann (1954) to emphasize "a descriptive recording of immediate subjective experience as reported."',99

In Patton's view, phenomenology explores "how human beings make sense of experience and transform experience into consciousness, both individually and as shared meaning. This requires methodologically, carefully, and thoroughly capturing and describing how people experience some phenomenon - how they perceive it, describe it,

\footnotetext{
${ }^{98}$ Schwandt, T. A. 1994. "Constructivist, Interpretivist Approaches to Human Inquiry” In Denzin, N. K. and Yvonna S. Lincoln (eds) Handbook of Qualitative Research. Thousand Oaks, CA: Sage Publications, p. 118.

${ }^{99}$ Patton, M. Q. 2002. Op Cit, p. 104.
} 
feel about it, judge it, remember it, make sense of it, and talk about it with others." In his view, to obtain such information, "one must undertake in-depth interviews with people who have directly (his emphasis) experienced the phenomenon of interest; that is, they have "lived experience" as opposed to secondhand experience."100 The phenomenological strategy was therefore the best way to generate the respondents' subjective experiences, perceptions of, and understanding of the reform program. The respondents' subjective experiences were at the center of the research.

\section{Study Sample:}

It was important to interview people who were involved in the reform process and who have been working in the Ugandan and Tanzanian public services prior to and during the reform processes. The study therefore used purposive sampling to maximize variation and to identify information-rich subjects that would provide in-depth data to facilitate inquiry into, and understanding of the CSRP. Patton (2002) asserts that in purposive sampling "cases for study are selected because they are "information rich" and illuminative, that is, they offer useful manifestations of the phenomenon of interest; sampling, then, is aimed at insight about the phenomenon, not empirical generalization from a sample to a population.",101

Key subjects, who were purposefully selected, were asked to recommend other people to talk to, based on their perception of who would have rich knowledge about the reform process. Snowball sampling worked well here because a good number of the

\footnotetext{
${ }^{100}$ Patton, M. Q. 2002. Ibid, p.104

${ }^{101}$ Patton, M. Q. 2002. Op Cit, p. 40.
} 
respondents were recommended to me. As a result, although interviews started with a short list of informants, the list grew (like a snowball) as names were added through the referral of informants. However, not all the people agreed to be interviewed. In the end, after reaching theoretical saturation, the study subjects were thirty five respondents comprising Commissioners, senior officers and administrators, and departmental heads in the three ministries, and the members of the PSRRC. Twenty respondents were Ugandan while fifteen were from Tanzania. Because qualitative research "typically focuses in

depth on relatively small samples, even single cases purposefully," ${ }^{\prime 102}$ the study sample is acceptable. The goal of the study is not to make empirical generalizations, rather, to get insight into, and an in-depth understanding of, the performance of the CSRP in the two countries based on the perception of the civil servants. Table 3.1 summarizes the demographic information for the subjects of my study.

\subsection{DATA COLLECTION TECHNIQUES}

The study relied on qualitative data collection techniques as are commonly used in case study research. Generating data via qualitative methods was preferred because the objectives of the study demanded very specific information that could be best generated from interviews with specific, albeit many, categories of respondents and personalities. The major sources of data for the study entail primary data generated from face to face interviews and content analysis of official documents and publications, news papers, and online sources.

\footnotetext{
${ }^{102}$ Patton, M. Q. 2002. Ibid. p. 230.
} 
Table 3.1 Demographic Characteristics of the Study Sample.

\begin{tabular}{|c|c|c|c|c|}
\hline \multirow[b]{2}{*}{ CHARACTERISTIC } & \multirow{2}{*}{$\begin{array}{l}\text { NUMBER } \\
\text { UGANDA } \\
\end{array}$} & \multirow{2}{*}{$\begin{array}{c}\text { NUMBER } \\
\text { TANZANIA }\end{array}$} & \multicolumn{2}{|c|}{ PERCENTAGE } \\
\hline & & & UGANDA & TANZANIA \\
\hline \multicolumn{5}{|l|}{ Gender } \\
\hline Male & 12 & 11 & 60 & 73 \\
\hline Female & 8 & 4 & 40 & 27 \\
\hline TOTAL & 20 & 15 & 100 & 100 \\
\hline \multicolumn{5}{|l|}{ Rank } \\
\hline Chief Technical Advisor ${ }^{1}$ & 0 & 1 & 0 & 7 \\
\hline Permanent Secretary & 0 & 1 & 0 & 7 \\
\hline Under Secretary & 1 & 0 & 5 & 0 \\
\hline Director $^{2}$ & 1 & 1 & 5 & 7 \\
\hline Assistant Director & 0 & 1 & 0 & 7 \\
\hline Commissioner & 4 & 1 & 20 & 7 \\
\hline Assistant Commissioner & 4 & 1 & 20 & 7 \\
\hline Head of Department & 2 & 3 & 10 & 20 \\
\hline Middle Level Officers & 8 & 6 & 40 & 40 \\
\hline TOTAL & 20 & 15 & 100 & 100 \\
\hline \multicolumn{5}{|l|}{$\begin{array}{l}\text { Years in the Public } \\
\text { Service }\end{array}$} \\
\hline Above 20 & 12 & 9 & 60 & 60 \\
\hline $10-20$ & 6 & 3 & 30 & 20 \\
\hline Below 10 & 2 & 3 & 10 & 20 \\
\hline TOTAL & 20 & 15 & 100 & 100 \\
\hline \multicolumn{5}{|l|}{ Engaged in the PSRRC } \\
\hline Yes & 4 & 2 & 20 & 13 \\
\hline No & 16 & 13 & 80 & 87 \\
\hline TOTAL & 20 & 15 & 100 & 100 \\
\hline
\end{tabular}

The Chief Technical Advisor, Public Service Reform Program, President's Office-Public Service Management, Government of Tanzania.

${ }^{2}$ Director Administrative Reform Program, Ministry of Public Service, Government of Uganda. 
Secondary information from scholarly journals, books, and other publications was also utilized. The use of a variety of data sources in a study is what Denzin (1978) called data triangulation. ${ }^{103}$ Triangulation strengthens the study because no single source of data can be trusted to generate a complete perspective. According to Patton (2002), "studies that use only one method are more vulnerable to errors linked to that particular method (e.g., loaded interview questions, biased or untrue responses) than studies that use multiple methods in which different types of data provide cross-data validity checks." 104 Interviews:

Berg (2004) defines interviews as "a conversation with a purpose" and that purpose is "to gather information." ${ }^{105}$ Babbie (2004) offers a similar view when he asserts that an interview undertaken in a qualitative study is "essentially a conversation in which the interviewer establishes a general direction for the conversation and pursues specific topics raised by the respondent." ${ }^{, 106}$ Interviews are a favored data generating mechanism because they enable the researcher to find out from subjects those things that cannot be directly observed. Patton (2002) asserts that interviews "allow us to enter the other person's perspective." In his view, "Qualitative interviewing begins with the assumption that the perspective of others is meaningful, knowable, and able to be made explicit." ${ }^{\prime 107}$ Interviews for my study were held in the quest for not only the experience of those in

${ }^{103}$ Denzin, N. K. 1978. The Research Act: A Theoretical Introduction to Sociological Methods. New York: McGraw-Hill.

${ }^{104}$ Patton, M. Q. 2002. Ibid, p .248.

${ }^{105}$ Berg, B. L. 2004. Ibid, p. 75.

${ }^{106}$ Babbie, E. 2005. The Basics of Social Research. Belmont, CA: Thomson Wadsworth, p. 336.

${ }^{107}$ Patton, M. Q. 2002. Ibid, p. 341. 
leadership positions, but also the experience of ministry personnel, especially their views about the size, salary structure, capacity building, and ethics accountability of the Ugandan and Tanzanian civil services. The goal was to qualitatively get their understanding, interpretation, and subjective experiences of the reform.

The interviews were based on open-ended questions inquiring about the civil servants' perceptions of the reform program, their experiences with the reform, and what changes they have seen since the reform started. Questions were in a semi-standardized format (semi-structured format) because I had a number of predetermined open-ended questions which I asked all my participants in a fairly systematic and consistent order (see appendix 1 for the general interview schedule), but I also digressed, probed, and asked some exclusive questions to those subjects that occupied unique positions in the reform process. It was rewarding to have flexibility in wording the questions because this maximized my goal of generating diverse views from subjects especially bearing in mind that many of them played different roles in the reform process. All my subjects signed a consent form and were interviewed individually in their offices at their ministry headquarters in Kampala and Dar es Salaam. It was anticipated that some of the study participants might find the study politically sensitive and thus fail to freely express their views. Hence at the start of the interview, participants were assured that the ethical principle of subject confidentiality would be strictly observed. According to Babbie (2004), "the clearest concern in guarding subjects' interests and well-being is the protection of their identity." ${ }^{108}$ Ensuring subject confidentiality relaxed their fears and

${ }^{108}$ Babbie, E. 2005 Op Cit, p. 69. 
resulted in candid responses. The request of those respondents that asked for their identities not to be revealed has been honored in the text - only code numbers of the interviews are used. I am the only person with the key to the code numbers.

The interview process proceeded as follows: I initiated the conversation with a few words of appreciation for allowing me time to talk to the subject and then delved into the major questions. Some of the interviews with the permission of the interviewees were recorded using a digital recorder while others were not. While most interviews lasted 90 minutes (one and a half hours), the shortest was 40 minutes and the longest 120 minutes. All respondents were asked to detail their experiences and perceptions of the reform program, but some were asked specific and unique questions because of their roles in the reform process. It was important to listen to their answers attentively and where necessary, probe for clarification and more detail. Nonetheless, I was mindful of the fact that my presence and form of involvement, for instance how I listened, interrupted, digressed, probed, and initiated topics were all crucial to the respondents' responses. I therefore did my best to listen attentively, guide the interview by showing interest in responses, and by encouraging elaboration without being overbearing and interrupting often.

According to Patton (2002), "No matter what style of interviewing you use and no matter how carefully you word questions, it all comes to naught if you fail to capture the actual words of the person being interviewed. The raw data of interviews are the actual quotations given by interviewees. Nothing can substitute for these data: the actual things 
said by real people. That is the prize sought by the qualitative inquirer." ${ }^{\prime 109}$ In order for me to capture the said prize, responses of the respondents were audio recorded and recorded by hand as the interview was going on. Responses were abbreviated and written down in an informal shorthand that would make it easy for me to remember what the main and actual points were. Patton (2002) advises that the "use of the tape recorder does not eliminate the need for taking notes, but does allow you to concentrate on taking strategic and focused notes, rather than attempting verbatim notes."

The field notes were later within 15 hours of the interview rewritten and typed into a coherent format. It took approximately 4 hours to rewrite each interview. The digitally recorded interviews were transcribed within one week of the interview. All interviews were transcribed verbatim including respondents' nonverbal expressions like laughter, sighs, and long pauses. All typed field notes were edited to check for grammatical errors, repetitions, and data that could break the confidentiality of those participants that requested to remain confidential.

To verify the credibility of the data, I availed the edited versions of the interviews to my respondents so that they could ascertain that I did not misrepresent their views. Of the thirty five respondents, twenty-seven responded in the affirmative thereby approving the interviews while the remaining eight did not respond. I nonetheless used the interviews of the latter group as well.

\footnotetext{
${ }^{109}$ Patton, M. Q. 2002. Ibid, p. 380.

${ }^{110}$ Patton, M. Q. 2002. Ibid, p. 383.
} 
Documents and Records:

The present study placed a great amount of focus on documentary sources of data like newspapers, government documents, and other official documents through qualitative content analysis. According to Neuman (2000), "content analysis is a technique for examining information or content, in written or symbolic material (e.g., pictures, movies, song lyrics, etc)." $\mathrm{He}$ asserts further that in content analysis, "a researcher first identifies a body of material to analyze (e.g., books, newspapers, films, etc.) and then creates a system for recording specific aspects of it." ${ }^{, 11}$ Patton (2002) on the other hand, asserts that "content analysis usually refers to analyzing text (interview transcripts, diaries, or documents)." In my study, content analysis is used to make sense of qualitative data generated from personal interviews, documents, and records in order to identify core consistencies and meanings.

Patton (2002) asserts that "qualitative data consists of quotations, observations, and excerpts from documents. ${ }^{, 12}$ Indeed, documents and records constitute a rich source of information that serves to augment data collected via interviews. Documents for this study entail official government documents, reports, and publications, the WB and the IMF documents and publications, archival material, and newspapers. The resource centers and the libraries of the Ministries of Public Service, and other government archives in both countries were of utmost help. Many of the study participants generously provided their ministerial periodic reports, surveys, development plans, and written

\footnotetext{
${ }^{111}$ Neuman W. L. 2000. Op Cit, p. 34.

${ }^{112}$ Patton, M. Q. 2004. Op Cit, p. 47.
} 
speeches of ministers and other high level public service officials. Documents particularly provided a wealth of numerical data in the form of tables, figures, and graphs that I would not have generated through face to face interviews. The various government documents were instrumental in providing background and behind-the scenes data about the reform programs progression overtime.

The Ugandan and Tanzanian current daily newspapers accessed from Makerere University in Kampala, Uganda, and University of Dar es Salaam in Tanzania while undertaking field work were continually studied online when I returned to USA. Both universities have strong newspaper archives dating as far back as the colonial period so I got access to old newspapers. Old newspapers provided a great historical account of the economical, political, and institutional developments of the two countries. The current newspapers especially The Daily Monitor and The New Vision in Uganda, and The Daily News and The Guardian in Tanzania and The East African that covers news of the great lakes region provided a great deal of data not captured in official records. The newspapers were also instrumental in providing information regarding the ethical improprieties of the public servants. The use of two sets of newspapers for each country served as a checking mechanism to verify the accuracy of the stories carried in each especially in the Uganda case where the New Vision is deemed to be pro-government and the Monitor anti-government.

\section{The Internet:}

Online data was continually sought by researching the various websites of the Ministries covered in the study. The official websites of the IMF and WB, and Transparency International were also utilized and provided great data. Use of online 
sources came in very handy during the dissertation write up since they could be accessed anytime for more current information.

\subsection{DATA ANALYSIS}

According to Berg (2004), qualitative data analysis "makes sense of the information accessed during the getting-in stage."113 $\mathrm{He}$ asserts further that "analysis involves creating categories or themes and then sorting answers to questions or statements from the fieldwork into these categories."114 Patton (2002) offers similar views but also reveals that analyzing qualitative data is a daunting task: "The challenge of qualitative analysis lies in making sense of massive amounts of data. This involves reducing the volume of raw information, sifting trivia from significance, identifying significant patterns, and constructing a framework for communicating the essence of what the data reveal." ${ }^{115}$ In analyzing the data I collected, I did not divert from Berg's and Patton's approach. I utilized an inductive approach to thematic analysis and had a prolonged and substantial engagement with the field notes and the documents. Trochim (2005) defines the thematic analysis of text as "The identification of themes or major ideas in a document or set of documents. The documents can be any kind of text, including field notes, newspaper articles, technical papers, or organizational memos."

\footnotetext{
${ }^{113}$ Berg, B. L. 2004. Ibid, p. 76.

${ }^{114}$ Berg, B. L. 2004. Ibid, p. 200.

${ }^{115}$ Patton, M. Q. 2002. Ibid, p. 432.

116 Trochim, W. M. K. 2005. Research Methods: The Concise Knowledge Base. Cincinnati, OH: Atomic Dog Publishing, p. 128.
} 
Boyatzis (1998) asserts that "a theme is a pattern found in the information that at minimum describes and organizes the possible observations and at maximum interprets aspects of the phenomenon."117 In his view, there are five steps in developing inductive thematic codes namely; a) reducing the raw information, b) identifying themes within subsamples, c) comparing themes across subsamples, d) creating a code, e) determining the reliability of the code. ${ }^{118}$ It is the themes developed in this study that provided insight and interpretation of the data generated.

To undertake thematic development and analytical categorization, I reduced the data to manageable levels by use of coding. Neuman (2006) asserts that "coding data is the hard work of reducing large mountains of raw data into small, manageable piles." He asserts further that "in addition to making the data manageable, coding allows a researcher to quickly retrieve relevant parts of it." ${ }^{\prime 19}$ It was through coding that themes emerged from deep inside the raw data to the surface. Themes derived from coding are also known as codes. According to Miles and Huberman (1994), "codes are tags or labels for assigning units of meaning to the descriptive or inferential information compiled during a study. Codes are usually attached to "chunks" of varying size - words, phrases, sentences or whole paragraphs, connected or unconnected to a specific setting." ${ }^{\prime 20}$ As I read and re-read the field notes, major categories developed and certain specific salient

\footnotetext{
${ }^{117}$ Boyatzis, R. E. 1998. Transforming Qualitative Information. Thousand Oaks, CA: Sage, p. 4.

${ }^{118}$ Boyatzis, R. E. 1998 Ibid, p. 45.

${ }^{119}$ Neuman, L. W. 2006. $6^{\text {th }}$ ed. p. 460.

${ }^{120}$ Miles, M. B. and Michael, A. Huberman. 1994. Qualitative Data Analysis. Thousand Oaks, CA: Sage Publications, p. 56.
} 
and similar issues started emerging. The similar issues were grouped together and continuously studied until certain patterns and themes emerged. Caution was taken to sort and sift through the data to identify similar views, phrases, themes, and differences and commonalities between the responses of the different respondents so that credibility is ensured. Strauss and Corbin (1998) call this type of data analysis microanalysis. They assert that "Microanalysis involves very careful, often minute examination and interpretation of data." ${ }^{121}$ In their view, undertaking microanalysis enables the researcher to "examine the specifics of the data" and to study intently "what the interviewees are saying and how they are saying it." Micro analysis therefore is both a detailed descriptive and analytical mechanism for interpreting qualitative data. Strauss and Corbin put it well when the asserted that microanalysis helps in "making comparisons along the level of properties and dimensions and in ways that allow the analyst to break the data apart and reconstruct them to form an interpretive scheme."122

The analysis focused on developing patterns and themes that indicate changes witnessed as a result of the reform, problems encountered, and future prospects and recommendations for positive change. Since mine is a comparative study, focus was also placed on those patterns and themes that illustrated similarities and differences between the reform programs of the two countries. The overall themes that emerged from the respondents' perceptions of the reform programs were categorized under the following; views about the size of the civil service, views about salary structure, views about

\footnotetext{
${ }^{121}$ Strauss, A. and Juliet Corbin. 1998. Ibid, p. 58, (emphasis theirs).

${ }^{122}$ Strauss, A. and Juliet Corbin. 1998. Ibid, p. 65.
} 
capacity development, and views about ethics and accountability. The themes that emerged from my respondents' perception of the reform program are: doing more with less; improving remuneration; human resources development and capacity building; economic recovery and poverty reduction; and enhancing ethics and accountability. These themes reveal the study subjects' perceptions of the reform programs and are substantiated by raw data in chapters 6 and 7, the results analysis sections.

\subsection{RELIABILITY AND VALIDITY}

According to Neuman (2006), reliability means "dependability or consistency." He asserts further that reliability in research suggests that "the same thing is repeated or recurs under the identical or very similar conditions." Neuman propounds that validity "suggests truthfulness." In his view, "The absence of validity occurs if there is a poor fit between the constructs a researcher uses to describe, theorize, or analyze the social world and what actually occurs in the social world." ${ }^{123}$ Qualitative and quantitative researchers view and operationalize the terms reliability and validity differently. In fact, the two concepts are most commonly associated with quantitative measurement and research but this does not mean that qualitative research does not pay attention to them. Qualitative research deploys many data collections techniques in order to "record their observations

consistently" ${ }^{\prime 24}$ thereby maximizing reliability. When it comes to validity in qualitative research, Neuman asserts that qualitative researchers "are more interested in authenticity

\footnotetext{
${ }^{123}$ Neuman, L. W. 2006. Ibid, p. 188.

${ }^{124}$ Neuman, L. W. 2006. Ibid, p. 196.
} 
than in the idea of a single version of truth." In his view, "authenticity means giving a fair, honest, and balanced account of social life from the viewpoint of someone who lives it every day." He asserts further that those who undertake qualitative research "are less concerned with matching an abstract construct to empirical data and more concerned with giving a candid portrayal of social life that is true to the experiences of people being studied." 125 The portrayal of validity fits quite well with my study because I concentrated on capturing the public servants' views and on providing a detailed account of how they understand and perceive the reform programs.

Lincoln and Guba (1985) are in agreement with Newman when they assert that qualitative research is not geared towards generalizable truths but rather aims at generating meaningful conclusions, deeper understanding, and useful results. They proposed four criteria for judging the quality of qualitative research, criteria that compares well with that used in judging quality of quantitative work. In the latter, according to Cook and Campbell (1979), focus is normally placed on internal and external validity, reliability, and objectivity. ${ }^{126}$ Lincoln and Guba assert that in qualitative research credibility is analogous to internal validity, transferability analogous to external validity, dependability analogous to reliability, and confirmability analogous to objectivity. ${ }^{127}$ Table 3.2 offers the criteria for judging research quality in qualitative and

\footnotetext{
${ }^{125}$ Neuman, L. W. 2006. Ibid.

${ }^{126}$ Cook, T. D. and Donald T. Campbell. 1979. Quasi-experimentation: Design and Analysis Issues for Field Settings. Chicago, Ill: Rand McNally College Publishing Company.

${ }^{127}$ Lincoln, Y. S. and E.G. Guba. 1985. Naturalistic Inquiry. Berverly Hills, CA: Sage Publications.
} 
quantitative studies as advanced by Lincoln and Guba (1985) and Cook and Campbell (1979) respectively.

Table 3.2 Criteria for Judging Research Quality in Qualitative and Quantitative Studies

\begin{tabular}{|l|l|}
\hline $\begin{array}{l}\text { Criteria for Judging Quality of } \\
\text { Qualitative Research }\end{array}$ & $\begin{array}{l}\text { Criteria for Judging Quality of Quantitative } \\
\text { Research }\end{array}$ \\
\hline Credibility & Internal Validity \\
\hline Transferability & External Validity \\
\hline Dependability & Reliability \\
\hline Confirmability & Objectivity \\
\hline
\end{tabular}

Source: Lincoln, Y. S. and Egon G. Guba. 1985. Naturalistic Inquiry. Berverly Hills, CA: Sage Publications; and Cook, T. D. and Donald T. Campbell. 1979. Quasi-experimentation: Design and Analysis Issues for Field Settings. Chicago, Ill: Rand McNally College Publishing Company.

Credibility in qualitative research means that findings of the study are plausible from the viewpoint of the research participants. Trochim (2005) asserts that "since from this perspective the purpose of qualitative research is to describe or understand the phenomena of interest from the participants' eyes, the participants are the only ones who can judge credibility of results."128 I sought to enhance credibility of my results by offering my research subjects opportunity to vet the interview data and they agreed that the themes I developed adequately presented their views and perceptions. The feedback did not call for any changes. This process, commonly known as member checks, is encouraged by Lincoln and Guba (1985) who are of the view that such a process ascertains credibility because the researcher's depictions of reality are acknowledged as valid by the study subjects. To further enhance the credibility of my research, I made sure to carefully reflect upon and sort out my own biases and points of view regarding the

${ }^{128}$ Trochim, W. M. K. 2005. Ibid, p. 126. 
reform programs in the two countries so that I do not contaminate the findings with my biases.

Quantitative researchers focus on external validity - generalization - of findings more than qualitative researchers. According to Lincoln and Guba (1985), "the trouble with generalizations is that they don't apply to particulars"129 and therefore, qualitative researchers when dealing with findings are better off focusing on "transferability" and "fitness." According to Trochim (2005), transferability is the "degree to which the results of qualitative research can be generalized or transferred to other contexts or settings." In his view, in qualitative studies, "transferability is primarily the responsibility of the one doing the generalizing." This however does not mean that the researcher undertaking the study and reporting findings does not carry any responsibility. Indeed he adds that "The qualitative researcher can enhance transferability by doing a thorough job of describing the research context and the assumptions that were central to the research" 130 so that the one interested in making the transfer can make a knowledgeable decision to do so or not to.

Lincoln and Guba (1985) offer the same views by asserting that it is the role of the researcher to offer a thick description with the "widest possible range of information."131 They warn against seeking generalizations and emphasize that the context of the study limits such generalization. In the current study, I acknowledge that

\footnotetext{
${ }^{129}$ Lincoln, Y. S. and E.G. Guba. 1985, p. 110.

${ }^{130}$ Trochim, W. M. K. 2005. Ibid.

${ }^{131}$ Lincoln, Y. S. and Egon G. Guba. 1985. Naturalistic Inquiry. Beverly Hills, CA: Sage Publications, p. 316.
} 
"the degree of transferability is a direct function of the similarity between the two contexts. ${ }^{" 132}$ Because the contexts in Uganda and Tanzania are unique, transferability can only be made to countries with similar contexts, a very rare occurrence. Moreover, it is important to keep in mind that the findings are based on the perceptions of those public servants that I interviewed which perceptions cannot be ably generalized to those that were not interviewed. In essence attempts at transferability or generalization of the findings of this study can only be tentative rather than definitive, opening the way for future studies.

Dependability is another criteria used in assessing the quality of qualitative research and findings. Substituted for reliability by Lincoln and Guba (1985), dependability "emphasizes the researcher's responsibility do describe the ever-changing research context"133 instead of focusing on replicability of findings. My research has taken place in a dynamic economic and political context. Uganda held presidential and parliamentary elections in February 2006 while Tanzania held her own in December 2005. These elections had a great impact on the government programs including the civil service reform program. In the conclusions offered in chapter nine, effort is taken to reiterate the changes in the contexts and to illustrate how these changes affected the conclusions drawn.

The final criterion for the judging worth of qualitative research is confirmability. Confirmability is the degree to which research findings can be corroborated and be

\footnotetext{
${ }^{132}$ Lincoln, Y. S. and Egon G. Guba. 1985.

${ }^{133}$ Trochim, W. M. K. 2005. Ibid.
} 
shown to be unbiased. According to Trochim (2005), one of the strategies for enhancing this criterion is to "search for and describe negative instances that contradict prior observations." 134 For Lincoln and Guba (1985), confirmability is enhanced by triangulation. In this study, the use of triangulation of data sources served to enhance the confirmability of the results. It is important to note that my dissertation committee played a critical role in examining my data collection and analysis procedures and assessing the presence of bias in the study.

The above analysis shows that the study followed systematic data collection procedures, used multiple data sources, and utilized member checks. It has also been shown that a systematic search for alternative themes, divergent patterns, and rival explanations was engaged. It can confidently be asserted that this qualitative study is high quality, credible and trustworthy; and it offers a balanced view of the reform programs.

\subsection{SUMMARY}

Chapter three has described the qualitative methodology utilized in collecting, analyzing, and interpreting data in the study. Data were collected through face to face interviews undertaken purposively and augmented by network sampling. Content analysis was also undertaken to supplement the data collected via interviews. Data were analyzed inductively by developing themes that reveal the perceptions of the various respondents about the civil service reform programs in Uganda and Tanzania.

\footnotetext{
${ }^{134}$ Trochim, W. M. K. 2005. Ibid.
} 


\section{CHAPTER 4: COLONIAL HERITAGE AND BUREAUCRATIC DEVELOPMENT IN UGANDA AND TANZANIA: A HISTORICAL OVERVIEW}

\subsection{INTRODUCTION}

Colonialism and its effects on the colonized be they in Africa, Asia, or Latin America, have for long captured the attention of political scientists, economists, historians, social anthropologists, and other scholars. Controversy abounds the analysis of the colonial impact with various scholars emphasizing the destruction unleashed and left behind by the colonialists while others focus on the enlightening role that was played. When it comes to the administrative and bureaucratic impact, agreement remains elusive still, as conflicting schools of thought advance the merits and demerits of the colonial bureaucracy. In Africa, the colonialists were confronted with numerous alternatives in fashioning local administrative bureaucracies that could ably exercise authority over the indigenous peoples and function efficiently by western bureaucratic standards. This was basically because different African societies were uniquely organized administratively, culturally, politically, and socio-economically in a manner that could lend them to colonial adaptation and manipulation.

In chapter four, I examine the historical development of bureaucracy in Uganda and Tanzania. Specifically, the chapter offers a historical background to bureaucratic institutionalization in the two countries by focusing on the native systems of administration, the colonial impact, and post-colonial developments. It is shown that Uganda had a relatively developed traditional system of administration that the British used to institute indirect rule. It is also shown that because Tanzania lacked traditional institutions, the colonial administrations created tribes which were subsequently used to 
administer the colony. The discussion addressed the colonial administrative and bureaucratic manifestations in the countries. The chapter shows that the British introduced a western style system of administration and laid the foundation for efficient civil services albeit to only meet the needs of the colonial power.

It was also shown that the post-independence bureaucracies retained the colonial features and in some cases entrenched them. Administrative centralization for instance was deepened in both countries. However, Tanzania attempted to break away from the colonial legacy by instituting African socialism and a single party system. It should be noted that because the two countries were at different stages of development prior to colonialism and their indigenous set up was not uniform, the analysis hinges on the unique characteristics of each country and how they facilitated/hindered the colonial administrative system and subsequent post-colonial bureaucratic development.

\subsection{ADMINISTRATION IN INDIGENOUS TERRITORIES IN PRE-COLONIAL UGANDA}

Traditional societies in pre-colonial Uganda were organized administratively, culturally, politically, and socio-economically, and were at varying stages of development prior to colonial penetration. Numerous writers, European explorers, missionaries, and colonial administrators acknowledged that there was a well established and intricate indigenous system of administration in native territories of pre-colonial Uganda. ${ }^{135}$ Indeed much of pre-colonial Africa was characterized by complex traditional

\footnotetext{
${ }^{135}$ See Lord Hailey, W. 1950. Native Administration in the British African Territories. London: His Majesty's Stationery Office; Kenneth Ingham. 1962. A History of East Africa. London: Longmans; Barber, William. 1961. The Economy of British Central Africa. London: Oxford University Press. Fleming,
} 
societies with high levels of development; for instance, Kingdoms like the Ashanti in Ghana, Oyo (Yoruba) in Nigeria in present day Western Africa, and the Southern African Kingdoms of Zulu and Monamotapa to mention a few, are examples of traditional African societies that had coherent systems of organization that facilitated activities like trade, collection of taxes, and the exercise of political authority and leadership.

Pre-colonial Uganda in contrast to pre-colonial Tanzania had numerous traditional kingdoms with clearly articulated administrative and political roles. Among them are the Ankole Kingdom, the Buganda Kingdom, Bunyoro Kingdom, Busoga Kingdom, and the Toro Kingdom. However, the most notable traditional territories were the Buganda Kingdom, found in central Uganda, and Bunyoro Kingdom in western Uganda. According to Fleming (1966), "the East African interlacustrine kingdoms and chiefly societies possessed a political structure with well-articulated authority roles with varying degrees of differentiation from the kinship system." He adds further that "there is some evidence which suggests that in at least two of the Uganda Kingdoms (Buganda and Bunyoro) a type of civil service had existed before British intervention."

The Buganda Kingdom is located in the south-central region of Uganda and includes most of the area surrounding the northern shores of Lake Victoria. It is estimated that the ruling dynasty of kings was established in the mid-14th century AD. The people

\footnotetext{
William, G. 1966. "Authority, Efficiency, and Role Stress: Problems in the Development of East African Bureaucracies”, In Administrative Science Quarterly, Vol. 11, No. 3, pp. 386-404. Mair Lucy. 1977. Primitive Government: A Study of Traditional Political Systems in Eastern Africa. Bloomington: Indiana University Press.

${ }^{136}$ Fleming, W. G. 1966. "Authority, Efficiency, and Role Stress: Problems in the Development of East African Bureaucracies.” Administrative Science Quarterly, Vol. 11, No. 3, p. 389.
} 
of Buganda are known as Baganda (Muganda - singular) and their language is Luganda. When the early missionaries and later the British colonialists arrived in the Kingdom, they found it highly developed with a viable government system centered around the king known traditionally as the Kabaka. The kingdom had royal tax collectors, armies, and an organized civil society that carried out the King's directives. The administrative structure spanned from the King to the County (Saza) chief, downwards to a Sub-county (Gombolola) chief, and further down to a Parish (Muluka) chief. Because the colonial officers were few, Buganda system made it easy for the British to manipulate it and use it to enforce their administration and hegemony through out the Protectorate. ${ }^{137}$ According to Burke (1964), "British influence and administration in Uganda were first established in the Kingdom of Buganda. There the early English explorers, administrators and missionaries found a sophisticated political system replete with king, court, and hierarchy of chiefs which resembled that with which they were already familiar." ${ }^{, 138}$ Hailey (1950) holds a similar view when he asserts that the Kingdom of Buganda "constituted a well established organization of rule which could with advantage be permitted to continue in the administration of local affairs under the guidance and control of the Protectorate Government." ${ }^{\prime 139}$ Kenneth Ingham (1962) acknowledges the same point when he asserts that "the leading part played by the Buganda Kingdom in the affairs of the Protectorate

\footnotetext{
${ }^{137}$ Uganda was brought under Britain's influence in 1890 but the British government gained direct responsibility for its administration in 1893.

${ }^{138}$ Burke, F. G. 1964. Local Government and Politics in Uganda. Syracuse: Syracuse University Press, p. 33.

${ }^{139}$ Lord Hailey, W. 1950. Native Administration in the British African Territories. London: His Majesty's Stationery Office, p. 1.
} 
was also due to its indigenous system of centralized, autocratic, and bureaucratic government."140

It is therefore not surprising that Buganda served as the launch pad for the entrenchment of British colonial rule and the expansion of this rule to other territories outside Buganda. Moreover, the kingdom availed a considerable portion of its military and other materials as it vied for a favored and privileged position. Indeed, the Buganda Kingdom was viewed as a junior partner of the British in the subjugation of the rest of the country. It should be noted that the colonial administrators could not make themselves directly responsible to every citizen under their authority hence it was expedient to entrust responsibility to African subordinates. This is the essence of indirect rule. ${ }^{141}$ The policy of indirect rule is credited to Sir Frederick Lugard who devised it as an expedient method of governing Nigeria. Iliffe (1979) asserts that "Its essence was the complete integration of indigenous political systems into the colonial administration so that there are not two sets of ruler - British and Native - working either separately or in co-

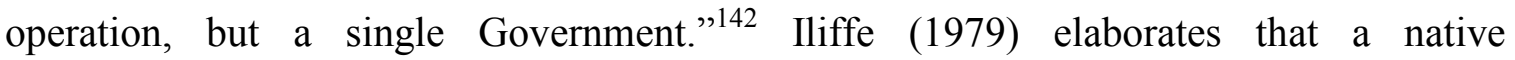
administration under indirect rule consisted of three parts: " a native authority - chief, council, or some combination of these - with legislative and executive powers; native courts; and a native treasury, which collected all taxes, remitting a percentage to the

\footnotetext{
${ }^{140}$ Ingham, K. 1962. A History of East Africa. London: Longmans, p. 239.

${ }^{141}$ Indirect rule is a system of colonial administration that was utilized by the British in their colonial territories. Under this system, existing indigenous political machineries are utilized to administer colonial rule. Hence in Uganda, native Ugandans were relied upon for the implementation of colonial policies.

${ }^{142}$ Iliffe, J. 1979. A Modern History of Tanganyika. Cambridge: Cambridge University Press, p. 319.
} 
central government and retaining the rest to pay the native authority and finance local works and services."143

Sir Donald Cameroon, the governor responsible for the implementation of indirect rule in Tanzania (then known as Tanganyika) from 1925-1931, asserted that "The policy of Native Administration of the indirect character ....is therefore in the first instance a measure of expediency. It is impossible for the Administrative Officer to get in touch with the whole of a primitive people, and it is impossible for financial reasons.",144 Therefore, where the colonialists found persons that already commanded authority as in Buganda, and who were willing to exercise it in furtherance of the colonial masters' government ideals, the colonial administration naturally chose them as assistants. According to Burke (1964), "wherever the British flag was raised in Uganda an administrative system patterned on that which the British had first observed and learned to admire in Buganda was super-imposed over the traditional polities." He asserts further that "chieftainship posts in these newly subjugated areas were often filled by Baganda, and to them went the spoils of domination." "145 The Buganda-imperial British colonial rule relationship epitomizes indirect rule at this best. It should be kept in mind that this special status enjoyed by the Buganda kingdom not only shaped the system of administrative development in Uganda, but also generated a significant effect on the country's political stance. Buganda's advantageous position complicated political

\footnotetext{
${ }^{143}$ Iliffe, J. 1979. Ibid p. 319-120.

${ }^{144}$ Donald Cameroon. 1939. My Tanganyika Service and Some Nigeria. London: George Allen and Unwin, p. 81 .

${ }^{145}$ Burke, F. G. 1964. Local Government and Politics in Uganda. Syracuse: Syracuse University Press, p. 13.
} 
integration and some of the political chaos that has plagued the country in the postindependence era has it roots in this colonial context. Burke (1964) reiterates the same point when he asserts that "the use of Baganda mercenaries and the export of the Buganda system of government through out Uganda is in part responsible for the general suspicion and distrust with which the Baganda are more or less held by most of their neighbors." He adds that, "the implementation of the Baganda system of chieftainship led to the institutionalization of a universal system of administration which in northern and eastern Uganda was in sharp contrast to the traditional local political systems." ${ }^{146}$

It should however be noted that the Buganda Kingdom was not very powerful at its founding and during its early years. It is has been documented that at its founding, it had a small territory and was considerably smaller and weaker than its rival Kingdom of Bunyoro. ${ }^{147}$ The Kingdom of Bunyoro previously known as Bunyoro-Kitara is what is traditionally known as the Babito dynasty. This kingdom is believed to have been the dominant political power among the pre-colonial societies in Uganda for several centuries. The kingdom's website asserts that its ancestors are "credited with the introduction of the unique, long horned Ankole cattle, coffee growing, iron smelting, and the first semblance of organized and centralized government under a king." ${ }^{\text {"148 }}$ It has also been asserted that by 1800 , the Kingdom's strength was at its zenith as most of present day Uganda, Kenya, the Democratic Republic Congo, Tanzania, and Sudan were under

\footnotetext{
${ }^{146}$ Burke, F. G. 1964. Ibid, p. 14.

${ }^{147}$ For a more detailed discussion of the historical origins of the Buganda Kingdom visit www.buganda.com, the official website of the Buganda Kingdom.

${ }^{148}$ The Origins of Bunyoro-Kitara Kings. http://www.bunyoro-kitara.com Accessed on April 6, 2007.
} 
its control. According to Wrigley Christopher (1996), there was immense rivalry between the Buganda and Bunyoro kingdoms characterized by constant fighting over territory but gradually and with the help of the British, Buganda was able to appropriate large chunks of territory from Bunyoro and ultimately grew in strength both economically and militarily. ${ }^{149}$

Prior to colonialism, authority in Bunyoro Kingdom was held by the Omukama (King). He ruled over many clans and tribes and held the power of life and death over his subjects. He among other things appointed as he pleased, the chiefs, who presided over the various divisions within the Kingdom, and granted land rights to subordinate chiefs who leased it to the masses for tribute. The Kingdom had a sophisticated system of justice based on a commonly shared and accepted knowledge of a set of sanctioned norms (native and custom laws) and coercion procedures when needed to ensure compliance. The Bunyoro traditional administrative system was hierarchically organized and the masses had recourse to appeal to the various stages of the hierarchy and in some cases to the King himself. Unlike the Buganda Kingdom which did not offer resistance to the British colonizers, the Bunyoro Kingdom under the leadership of King Kabalega fiercely resisted colonial domination. According to Ugandan historian Semakula Kiwanuka, "For nearly ten years, 1891-1899, Kabalega resisted British rule, hounded from one part of his kingdom to another, until he was overcome by armed violence in

\footnotetext{
${ }^{149}$ Wrigley, C. 1996. Kingship and the State: The Buganda Dynasty. New York: Cambridge University Press.
} 
1899 and deported to the Indian Ocean islands.. ${ }^{150}$ But it was in 1893, with the help of the Buganda Kingdom, that Kabalega was effectively deposed from the throne though it was not until 1896 that the British extended the Ugandan Protectorate to include Bunyoro and transferred two big counties from the Bunyoro to Buganda as a gesture of appreciation for Buganda's collaboration and support. ${ }^{151}$ Britain's alliance with the Buganda Kingdom was concretized in the Agreement of 1900 in which Great Britain legalized Buganda's political institutions and practices. Moreover, when conflict arose between the colonial government and Buganda, Buganda's laws seem to have been given the liberty to take precedence over Her Majesty's laws. The following paragraph from the 1900 Agreements illustrates:

"The laws made for the general governance of the Uganda Protectorate by Her Majesty's Government will be equally applicable to the Kingdom of Buganda except insofar as they may in any particular conflict with the terms of this Agreement, in which case the terms of this Agreement, will constitute a special exception in regard to the Kingdom of Buganda."

It is because of such actions that British imperial rule has been characterized as one that deployed a policy of divide and rule. From 1896, Bunyoro Kingdom was reduced to a "toothless bull dog" with subsequent kings enthroned by the British ruling as titular heads over what was to all intents and purposes a conquered and occupied kingdom. The local chiefs were replaced by Baganda chiefs, all important decisions were made by the British colonial administrators and even the most minute functions, had to be

\footnotetext{
${ }^{150}$ Semakula Kiwanuka M. 1970. "Colonial Policies and Administration in Africa: The Myths of the Contrasts." African Historical Studies, Vol. 3, No. 2, pp. 295-315.

${ }^{151}$ The two counties namely Bugangaizzi and Buyaga, reverted back to Bunyoro Kingdom following a referendum held in the same counties in 1964 two years after the country gained independence.

${ }^{152}$ The Uganda Protectorate. 1936. The Uganda Agreement - 1900. Laws of Uganda, Vol. VI, p. 1373.
} 
approved by the District Commissioner. It was not until 1933, that the British deemed it appropriate to grant the Omukama (King) Tito Winyi IV and the people of Bunyoro an agreement almost similar to the ones granted more than thirty years earlier to other kingdoms. Even then, the agreement was not as liberal as the one offered the Buganda Kingdom. While the Omukama was granted back some of his powers, he was required to obtain the approval of the central government before he could exercise authority. For instance he had to seek permission from the colonial administration before he could appoint or discharge major chiefs and officials. In effect, the Bunyoro King was rendered a powerless monarch. According to Semakula Kiwanuka (1970), "the aftermath of the imposition of colonial rule led to the emergence of two types of Africans: first, were the defeated who resigned themselves to the rule of the imperial conquerors; second, were the collaborators. The latter ..... were the men who read the signs of the times correctly and willingly jumped on the colonial bandwagon, thereby reaping the fruits of collaboration."153 The Baganda clearly fit the latter group while the Banyoro belong in the first group.

The British Colonial government therefore realized that it was prudent to appropriate and establish local native authorities to act as extensions of the colonial service bureaucracy and used brute force to do so in some instances. In the kingdom areas, various agreements, ${ }^{154}$ ordinances, and regulations were enacted establishing roles, responsibilities, and scope of authority for the appointed chiefs. In such areas, the

\footnotetext{
${ }^{153}$ Semakula Kiwanuka, M. 1970. Ibid, p. 297.

${ }^{154}$ In Uganda, the British colonial government signed agreements with the Buganda Kingdom in 1900, Toro Kingdom in 1900, Ankole Kingdom in 1901 and with the Bunyoro Agreement in 1933.
} 
colonialist' dilemma was how to increase the bureaucratic efficiency of the chiefs while at the same time allowing them means of retaining traditional authority. Cameroon, the firm believer in indirect rule warned that: "Experience has shown so often that to turn a chief into a placement of the government, a servant of the government, .... is to destroy his natural authority over his people.... If the chief is ignored or if he becomes a servant of the government, ... his people rapidly lose their respect for him and all he represents in their life founded on their own institutions handed down to them through the ages; his authority gradually dwindles and ultimately perishes." ${ }^{, 155}$ In such instances, Fleming (1960) asserts that the District Commissioner's role "approached the 'indirect rule' ideal. He would be concerned with a close supervision of the chief's work with his poll tax receipts, and with his judicial records, i.e., with improving his efficiency as a bureaucratic administrator." 156 According to Spear (2005), "The colonial administration was thus forced to rely on African auxiliaries to implement its rule, which it then claimed was based on the 'free choice of the people', the 'natural authority' of the chiefs, and the established customs of the people."157

Prior to British penetration, the non-kingdom parts of traditional Uganda had some form of administrative order organized around the indigenous clans, lineages, agesets, headsmen, and chieftainship system as well. Indeed the societies in northern and

\footnotetext{
${ }^{155}$ Donald Cameroon. 1939. My Tanganyika Service and Some Nigeria. London: George Allen and Unwin, p.93.

${ }^{156}$ Fleming, W. G. 1966. "Authority, Efficiency, and Role Stress: Problems in the Development of East African Bureaucracies." Administrative Science Quarterly, Vol. 11, No. 3, p. 397

${ }^{157}$ Spear, T. 2005. "Indirect Rule, the Politics of Neo-Traditionalism and the Limits of Invention in Tanzania." In Maddox, G. H. and James L. Giblin. In Serach of a Nation: Histories of Authority and Dissidence in Tanzania. Oxford: James Currey.
} 
eastern Uganda while lacking in traditional kingdomship replete with king, had viable clan systems and local consensual decision making mechanisms loaded with traditional authority. It is in these areas that the British found the greatest difficulty in superimposing their authority because such diffusely organized indigenous systems did not lend themselves to indirect rule. It is not surprising therefore that colonial occupation and extension of its authority to the northern and eastern parts of Uganda was not swift but gradual and it is in such instances that the Baganda were called upon. Fleming (1966) asserts that "The British mistakenly believed that all of the tribes in Uganda had chiefs, so at first organized administration throughout the Protectorate on the pattern of Buganda. This practice had deleterious consequences in the northern and eastern part of the country where few of the indigenous societies possessed clearly articulated political systems." ${ }^{158}$ Indeed, it was not until 1921 for instance, that civil administration was introduced to the Karimojong in northeastern Uganda.

According to Burke (1964), "when the colonial administration was extended into areas where an indigenous political system capable of providing a basis for indirect rule did not exist or could not be determined, the principle ran into considerable difficulty." He cites the Ugandan Nilotic north and Nilo-Hamitic northeast as areas lacking in Buganda-like hierarchy of chiefs. He reveals that what the British found in such areas was "either a confusing array of clan leaders, some of whom appeared to hold sway over considerable areas and lesser clan leaders, or a system of political authority built about institutionalized age-grades. Who were they to recognize as the indigenous authority and

\footnotetext{
${ }^{158}$ Fleming, W. G. 1966. "Authority, Efficiency, and Role Stress: Problems in the Development of East African Bureaucracies.” Administrative Science Quarterly, Vol. 11, No. 3, p. 392.
} 
subsequently to hold responsible for law and order and for the collection of taxes?" Burke answers his own question by observing that "As the Baganda already had an admirable system in operation, it followed that the solution to the impasse of ruling territories characterized by political anarchy was to superimpose a similar chiefly hierarchy over Buganda's "unorganized" neighbours. Thus "indirect rule" in its original sense was replaced by an indirect style of indirect rule. ${ }^{, 159}$ Fleming (1966) is in agreement when he contends that "in the northern areas of Uganda, the development of a chiefly bureaucracy had little basis in indigenous systems and the British used Buganda African agents as rulers there. ${ }^{, 160}$ It should however be noted that a combination of Baganda administrative chiefs, agents, and mercenaries were recruited to subdue the areas in addition to localized military forces and agreements with petty chiefs and clan leaders. An area was considered to be under British rule when levy and collection of taxes was successfully enforced.

It is apparent that the above mentioned colonial coping strategies altered the local social structures of the so called 'unorganized' societies in the northern and eastern parts of Uganda. British colonialism radically transformed the local cultural, social, and political structures by implanting an alien system of hierarchical chiefs to preside over all decision making in those areas. The chiefs were equipped with wide ranging powers and their authority was unquestionable. Lange (2004) asserts that "The chiefs were given executive, legislative, and judicial powers to regulate social relations in their chiefdoms, vast authority which was supposed to be grounded in preexisting tradition or custom, not

\footnotetext{
${ }^{159}$ Burke, F. G. 1964. Ibid, p. 34.

${ }^{160}$ Fleming, W. G. 1966. Ibid, p. 394.
} 
bureaucratic rules. ${ }^{\not 161}$ However, according to Fleming (1966), the chiefs were trapped between conflicting roles and responsibilities. "Each chief or headman endowed with "legal" power by the colonial administration was frequently faced with a difficult dilemma. In any given task - collecting taxes, growing cash crops, repairing roads, enforcing local laws and others - the African leader was often forced to choose between distasteful and incompatible courses of action." ${ }^{.162}$ In his view, the chief was placed between the proverbial rock and hard place any time he enforced directives from the district officer regardless of their basis in tribal tradition because by doing so, he lost "respect of his tribesmen and diminished his own customary authority" while if he refused to do so, whether through "subterfuge or outright insubordination", he would be labeled "inefficient and unreliable" or be dismissed from the service.

In the diffused traditional societies of northern and eastern Uganda, the colonially instituted officers and chiefs and the roles they played were in stark contrast with their clan-elder-based consensual decision making systems. Moreover, in the traditional norms, a chief was part of the society and not above it, his powers defined by tradition and not by the dictates of foreign superiors. For Ugandan historian Samwiri Karugire (1980), the colonial administrators introduced into those societies a "one-man rule"163 which was met with resentment and resistance. Yet for the colonizers, the chief's role was very critical not only for ensuring law and order and the collection of taxes, but for

\footnotetext{
${ }^{161}$ Lange, M. K. 2004. "British Colonial Legacies and Political Development." World Development. Vol. 32, No. 6, p. 907.

${ }^{162}$ Fleming, W. G. 1966. "Authority, Efficiency, and Role Stress: Problems in the Development of East African Bureaucracies." Administrative Science Quarterly, Vol. 11, No. 3, p. 390.

${ }^{163}$ Karugire, S. R. 1980. A Political History of Uganda. Nairobi: Heinemann Educational Books, p. 124.
} 
offering a buffer against native insurrection thereby ensuring the overall maintenance of the colonial system of political control. "While the colonial officer could use the chief for implementing unpopular policy, he was himself shielded from the opposition which might be aroused." 164

It can therefore be asserted that the system of indirect rule that was applied to the Ugandan Protectorate was not consistent. The colonial administration expeditiously utilized traditional processes, laws, and procedures when they served the colonial purposes and relied on expediency and coercion to exact obedience when the traditional norms became cumbersome or irrelevant. Although indirect rule supposedly worked through only pre-colonial systems and channels, the local institutions used by the British were to varying extents colonial constructs themselves as the domination efforts pursued in the northern and eastern parts of the country illustrate and in so far as native systems were manipulated to primarily serve the colonial government's interests. It should also be kept in mind that indirect rule was not pursued in order to keep the local Ugandans involved in the administrative process, but rather, it was adopted as an administrative convenience. Indeed, the colonial administration did not do much to preserve native authority, values, and norms. If anything, traditional authority was surrendered to the British Crown. Fleming (1966) is in agreement when he asserts that "The system of 'indirect rule' was devised, not so much out of philosophical concern for the maintenance of African tribal structure as out of practical necessity."

\footnotetext{
${ }^{164}$ Fleming, W. G. 1966. Ibid, p. 391.
} 
The colonial coping strategies not only altered the local social structures but also sowed the seeds that eventually germinated into some of the current problems afflicting Uganda. For instance, "the establishment of districts based wherever possible on tribal residence has contributed to a sense of district nationalism and separatism that in many cases did not exist prior to the arrival of the British and subsequent amalgamation of the parochial segments into districts. ${ }^{" 165}$ More so, in the kingdom societies, nationalism and feelings of separatism run high as these societies still strive for federal status, especially in Buganda. Such factors have not facilitated the quest for peaceful national integration.

From the above discussion, it is clear that traditional indigenous Ugandan societies were organized administratively, culturally, politically, and socio-economically, and were at varying stages of development prior to colonial penetration. It is partly because of this context that the British colonial administration pursued the policy of indirect rule by exercising power through the various traditional institutions and structures. Where such institutions were not viable, the context was radically altered by introduction of the chieftainship. Yet, the Ugandan traditional systems should not be romanticized. While they served the purposes of the time, they lacked the capacity and attributes necessary for the functioning of a modern state. Nonetheless, the colonial masters were not interested in modernizing the country and equipping it with the critical capacities beyond what was necessary for their operations. Rather, they realized that to reach their goals they had to manipulate or do away with the traditional systems, and replace them with bureaucratic organizations styled after the systems in their own

${ }^{165}$ Burke, F. G. 1964. Op Cit, p. 14. 
countries. British imperial rule therefore shaped the political, economic, and sociocultural structures as well as the administrative institutions of the country. Indeed, colonialism heavily influenced and fashioned state institutions and developmental trajectories of the post independence era. Before delving deeper into the legacy of colonialism on Uganda's bureaucratic development, it is crucial to take a historical look at Tanzania's indigenous administrative set up. The historical analysis is crucial for the eventual comparison of the bureaucratic functioning in the two countries.

\subsection{ADMINISTRATION IN INDIGENOUS TERRITORIES IN PRE-COLONIAL TANZANIA}

In Tanzania, the traditional administrative and political systems were not articulated as well as they were in Uganda. According to Illife (1979), "Tanganyika was not composed of tribes. Its groups and identities were formed in other ways... identification was totally relative to the spatial position of the speaker. By moving his home and adapting to a new environment a man changed his identity."166 In his view, identity categorizations developed as people moved around and adapted to specific environments in their search of pasture, cultivatable land, and other forms of livelihood.

He asserts further that, "In pre-colonial Tanganyika, each individual had belonged to several social groups: nuclear family and extended family, lineage and chiefdom, and perhaps clan and tribe. Circumstances had led some to emphasize one identity." ${ }^{167}$ It can therefore be said that, both political and administrative authority were scattered, and there

\footnotetext{
${ }^{166}$ Iliffe. J. 1979. A Modern History of Tanganyika. Cambridge: Cambridge University Press, p. 9-10

${ }^{167}$ Iliffe. J. 1979.Ibid, p. 318.
} 
were few power centers that could ably make binding decisions for the community. Even though different kinship groups were in existence, "what political power did exist in these tribes was neither concentrated nor highly visible, and limited powers of decision making were variously distributed between lineage and clan heads, village elders, and religious leaders." ${ }^{168}$ It is therefore not surprising that tribal rivalry was not as pervasive in precolonial Tanganyika as it was in pre-colonial Uganda and even "where contrasting environments and cultures were juxtaposed, antagonism co-existed with a lively exchange of goods."169 But after colonial penetration, identities and loyalties became more complex and tribal divisions rigidified as people identified themselves as "Muslims, Christians, Protestants, Catholics, clerks or workers, Africans, or even Tanganyikans...Men devoted as much energy to consolidating and advancing tribes as their children would later devote to creating a nation." ${ }^{170}$ In Iliffe's view, the people in Tanganyika gained tribal consciousness as a result of socio-economic change and colonial government policies.

Colonial interest in Tanganyika was first developed by Germany prior to the 1884 Berlin Conference on the partition of Africa and it is a state of semi-statelessness that the German colonialists encountered upon arrival. While it might be easy to conquer stateless societies, in the case of Tanganyika, being stateless did not mean that it was a walk-over for the Germans and even after conquest, reigning over stateless societies can be quite a

\footnotetext{
${ }^{168}$ Fleming, W. G. 1966. Op Cit, p. 389.

${ }^{169}$ Iliffe, J. 1979. Op Cit, p. 19-20.

${ }^{170}$ Iliffe, J. 1979. Ibid, p. 318.
} 
daunting task as the Germans discovered. They met great resistance from the Arabs at the Indian Ocean coast, and from the clan heads in the grassland interior. It has been asserted that African responses to colonial invasion fall into three major categories namely armed resistance, negotiation, and collaboration. ${ }^{171}$ But according to Iliffe (1979), the situation was different in Tanganyika:

"Many peoples reacted in different ways at different times. Machemba, most persistent of opponents, negotiated at intervals. Sina began by fighting and ended as a reliable ally. Armed resistance was not especially common among the most militarized societies. The Masai were in no position to fight. Unyanyembe had a less warlike past than Urambo. Nor was it less enlightened peoples who fought....Rather, armed resistance, negotiation, and collaboration were tactical choices, alternative means of achieving the same end: the greatest possible independence and power." 172

It can therefore be asserted that the German experience was quite different from the one the British encountered in Uganda. Clearly, in the Ugandan case, the Baganda were outright ardent collaborators through out the colonial period while the Banyoro and other areas remained colonial adversaries or reluctantly subservient at best.

In 1891, the German government took over direct administration of the Tanganyika territory with the appointment of a governor in Dar es Salaam but it was not until 1898 that the Germans claimed control over most of Tanganyika. Because of Tanganyika's large size, diverse terrain, population distribution, and poor communication networks, it was difficult to reach remote villages. According to Iliffe (1979), "to the end of their occupation, German rule was spread most unevenly over Tanganyika. Many

\footnotetext{
${ }^{171}$ Ranger, T. O. 1969. "African Reactions to the Imposition of Colonial Rule in East and Central Africa”, in Gann, L. H. and Peter Duignan (ed) Colonialism in Africa 1870-1960. Cited by Iliffe J. 1979.

${ }^{172}$ Iliffe, J. 1979. Op Cit, pp. 105-106.
} 
Grenzwildnisse $e^{173}$ remained almost entirely ungoverned." ${ }^{174}$ In his view, early German rule over Tanganyika "used its bands of gunmen to maintain authority over compliant local leaders ... and its 'conquest' was often an extension of tribal war in which the Germans shared the plunder."175

The Germans endeavored to extend and entrench their authority and control over the territory by establishing administrative systems in areas that were densely populated and economically viable. Administrative districts were established, each headed by a district officer; by 1914 there were 22 administrative districts. ${ }^{176}$ Like his British counterpart in Uganda, a German administrative officer wielded a lot of power and authority. But because of the size of the Tanganyikan territory and poor communication, districts officers enjoyed more autonomy and decision making powers and were more authoritarian than their Ugandan counterparts. "No provincial commissioners supervised district officers. A remote station could expect a visit from a senior official only once a decade.... In 1914 seven of the twenty district officers had held their posts for seven years or more. Their rule was openly based on force and few traveled without armed escorts.... With their brutal soldiers and police, German officials inspired great terror."177 Unlike Uganda therefore, Tanganyika under Germany experienced an overwhelmingly direct rule with elements of indirect rule.

${ }^{173}$ Grenzwildnisse is a German word for Tanganyikan wilderness, generally tsetse-fly infested woodland.

${ }^{174}$ Iliffe, J. 1979. Ibid, p. 118.

${ }^{175}$ Iliffe, J. 1979. Op Cit, p. 117.

${ }^{176}$ For a detailed description of the consolidation of German rule in Tanzania, see Iliffe (1979) chapter 3 , "German Conquest".

${ }^{177}$ Iliffe, J. 1979. Ibid, p. 119. 
In spite of the brute force used by the Germans, some economic development was realized, an administrative system was established, and many natives were offered education. It has been argued that "Despite some British propaganda to the contrary, the Germans had not in fact deliberately set about the destruction of all forms of indigenous authority, and had in places incorporated cooperative local chiefs into the administration." 178 The local bureaucracy was administered through agents known as 'akidas' and 'jumbes'. The 'jumbes' were headmen or leaders of clans or small groups of people and a number of them would be under the authority of an 'akida'. ${ }^{179}$ 'Akidas' were "government-appointed agents whose duty was to assist the European officials with the collection of the tax and the enforcement of the law on a day-to-day basis." ${ }^{180}$ Frequently, the 'akidas' were coastal Arabs and people of Arabic descent that spoke Swahili. They were not particularly well liked by the inland natives because of their eagerness to harass and intimidate the local natives ${ }^{181}$. But it has been argued that not all ‘akidas' were "foreign". According to Willis (1993), "Some of the akidas appointed by the Germans were local village headmen, and others were coastal people who through trade and raiding had succeeded in building a position for themselves as local patrons in the pre-colonial period." 182

\footnotetext{
${ }^{178}$ Willis, J. 1993. "The Administration of Bonde, 1920-60: A Study of the Implementation of Indirect Rule in Tanganyika." African Affairs, Vol. 92, p. 55.

${ }^{179}$ Were, G. S. and Derek A. Wilson. 1984. East Africa through a Thousand Years: A History of the Years $A D 1000$ to the Present Day. New York: Africana Publishing Company.

${ }^{180}$ Willis, J. 1993. Ibid, p. 55.

${ }^{181}$ Were, G. S. and Derek A. Wilson. 1984.

${ }^{182}$ Willis, J. 1993. Ibid, p. 56.
} 
It has been asserted that there were two major phases of district administration under the German colonial government. The first phase was initiated in the 1880 s and its focus was military security and political control of the colony. In this phase, there was heavy reliance on coercive means and coalition with cooperative natives. Peoples with out recognized chiefs (stateless peoples) had headmen forced upon them, while some chiefdoms were altered and reconstructed. The colonial demands included "recognition of Germany paramountcy, provision of labor and building materials, and use of diplomacy rather than force in settling disputes." In turn, the Germans would provide "political and military support for their allies." ${ }^{, 183}$ The second phase was characterized by "the collapse of the local compromises established in the $1880 \mathrm{~s}$ " 184 mainly because of the imposition of the hut tax in 1898 , a policy that was not palatable to the natives. According to Iliffe (1979), another reason for the collapse of the local compromises was the "tension between the needs for political control and the needs for efficient administration. Control required powerful allies with obedient followings. Administration required efficient agents who could impose uncongenial innovations. Only rarely could one man fulfill both functions successfully as the Germans began to make more extensive demand on their subjects." ${ }^{\text {185 }}$ As the collaboration buckled and as administrative demands imposed intensified, the natives increasingly felt disenfranchised and began agitating against colonial rule.

\footnotetext{
${ }^{183}$ Iliffe, J. 1979. Ibid, pp. 119-120.

${ }^{184}$ Iliffe, J. 1979. Ibid, p. 120.

${ }^{185}$ Iliffe, J. 1979. Ibid, p. 121.
} 
The 'akidas' administrative system functioned fairly efficiently for some time but gradually became a barrier between the natives and the colonialists. The Germans were unable to make real contact with, and to understand the native peoples, but rather hastened to establish their authority and reshape the economy by introducing extensive agricultural developments. It should be kept in mind that the main reason for German interest in Africa just like all other colonialists was to generate economic wealth. The natives however were not keen to embrace sudden changes in their livelihoods and railed against the changes forced upon them. Such disgruntlement resulted in what came to be known as the Maji Maji rebellion of 1905-1907 in which the natives in the southeast of Tanganyika refused to abide by the government's directive to grow cotton. What ensued was a bloody and tumultuous period in which the Germans ruthlessly used brute force to quell the wide-spreading African rebellion. According to Were and Wilson (1984), the government had to call in reinforcements and once they arrived, the Africans were defeated. "Their leaders were "executed, crops destroyed, houses burned, and many people were imprisoned or hanged....The number of Africans killed is not known but it could have been between 75,000 and 120,000."186 The Maji Maji uprising has been depicted as "a unique and exceptional primary response to colonial oppression. The unprecedented unity of different ethnic groups attributed to the maji ideology has become an icon of anti-colonial protest in Africa." 187 Iliffe (1979) asserts that the Maji Maji rebellion "was an explosion of African hatred of European rule. It was a final attempt by

\footnotetext{
${ }^{186}$ Were, G. S. and Derek A. Wilson. 1984. p. 136.

${ }^{187}$ Monson, J. 1998. "Relocating Maji Maji: The Politics of Alliance and Authority in the Southern Highlands of Tanzania, 1870-1918. Journal of African History, Vol. 39, p. 97.
} 
Tanganyika's old societies to destroy the colonial order by force, and its failure made the passing of the old societies inevitable."188

After the rebellion was defeated, the Germans attempted to reform the administrative system by incorporating more native Tanganyikans in the bureaucracy and by fashioning the system on traditional patterns of African society. However, as they attempted to put their colonial house in order, an international crisis that culminated into the First World War (1914-1918) was brewing. Germany and her allies were defeated and the victorious European powers usurped her colonies. Under the Mandate system put in place by the League of Nations, Tanganyika became a British territory in 1920 . The Mandate accorded Britain full powers of administration over Tanganyika.

Upon assuming control over Tanganyika, the British initially retained German established administrative structures. Iliffe (1979) asserts that "Until 1925 Governor Byatt preserved the German administrative structure, with 22 district officers reporting to the secretariat in Dar es Salaam and using chiefs or akidas as agents."189 This administrative system, dysfunctional under German rule, did not improve under British rule. It was therefore soon decided that in order to have administrative efficiency, some form of decentralization to the native authorities had to be effected so that local areas gain some administrative autonomy to make laws, collect taxes, and have local leaders. A Governor that was very familiar with the functioning of indirect rule, having exercised it in Nigeria for seventeen years, was brought into Tanganyika to straighten the system. The

\footnotetext{
${ }^{188}$ Iliffe, J.1979. p. 168.

${ }^{189}$ Iliffe, J. 1979. Ibid, p. 319.
} 
new governor, Sir Donald Cameron is said to have been 'appalled by the lack of administrative policy'. Iliffe cites him lamenting to his superior Lugard thus; "I found each District Officer doing just as he pleased. There are no general instructions on any question of native policy... Administrative Officers are engaged in every task except Political work which is neglected.... Indirect rule is a fiction.... The people are out of hand because the Chiefs can no longer punish them."190 The British therefore decided that just like Uganda, and Nigeria, the territory must be "primarily a Black man's country" and hence hastened to introduce indirect rule.

According to Mair (1977), British colonial theory held the principle that "the indigenous political system, whatever it was, must be utilized as the starting-point for any development." She asserts further that "In Uganda the organization of the Ganda kingdom so much impressed the early Protectorate officials that after streamlining it a little they made it a model for the whole of the territory."191 However, the situation was drastically different in predominantly stateless Tanganyikan societies which rendered the establishment of indirect rule complicated. According to Mamdani (1996) Cameron sought to overcome the obstacle of stateless societies through three alternatives. "One option, as pursued with the Sagara, was to subordinate them to a neighboring chiefdom. A second option was to convert religious leaders into administrative chiefs, as was indeed done with the Masai. A third option, almost always disastrous, as with the Makonde, was

\footnotetext{
${ }^{190}$ Cameron to Lugard, 12 September 1925, in Bates, 'British administration', p. 62 n. 2. Cited in Iliffe, J. 1979, p. 320.

${ }^{191}$ Mair, L. 1977. Primitive Government: A Study of Traditional Political Systems in Eastern Africa. Bloomington, IN: Indiana University Press, p. 214.
} 
to elevate one of several village headmen into a chief. In the process, however, several successes were registered in creating tribes where none had existed before, the most outstanding being the case of the Nyakyusa around Lake Victoria."192 The British therefore invented chiefs in most of the stateless societies in Tanzania as they did in the non-kingdom areas in Uganda. Spear (2005) asserts that "Chiefs were inventions in two senses: first, the men colonial authorities appointed lacked traditional legitimacy, and secondly, the positions to which they were appointed were either creations of the colonial administration or had been so corrupted by their incorporation into the colonial administrative hierarchy, with its unpopular demands to collect tax, raise labor, ...that they no longer represented established patterns of authority at all.",193

It can therefore be argued that, in their quest to establish an efficient bureaucracy that is based on indirect rule, the British set about to not only "discover the tribal authority structures and endow them with legal powers as local "native authorities"',194 but to manufacture some where none existed. Iliffe (1979) asserts that the indirect rule policy as was implemented in Tanganyika "Although conservative in origin it was radical in effect because it rested on historical misunderstanding. The British wrongly believed that Tanganyikans belonged to tribes; Tanganyikans created tribes to function within the colonial framework." In his view, "Europeans believed Africans belonged to tribes;

\footnotetext{
${ }^{192}$ Mamdani, M. 1996. Citizen and Subject: Contemporary Africa and the Legacy of Late Colonialism. Princeton: Princeton University Press, p. 81.

${ }^{193}$ Spear, T. 2005. "Indirect Rule and Politics of Neo-Traditionalism and the Limits of Invention in Tanzania." In In Search of a Nation: Histories of Authority and Dissidence in Tanzania. Gregory, H. Maddox. and James L. Giblin eds. Oxford: James Currey.

${ }^{194}$ Fleming, W. G. 1966. p. 395.
} 
Africans built tribes to belong to." 195 The implementation of indirect rule and the creation of Native Authorities in colonial Tanganyika provide what may be viewed as the most prominent example of the "creation of tribes ${ }^{, 196}$ in Africa. Nonetheless, indirect rule did not become the norm across all the societies in Tanganyika. Willis (1993) asserts that "In Bonde the introduction of indirect rule, and the creation of tribal authorities, was for many years resisted by local officials."197 Just like in the non-kingdom areas in northern Uganda, local circumstances dictated whether or not, and how, indirect rule was implemented.

While in the Ugandan case, the situational constraints did not deter the British from crafting the system, in Tanganyika it was not only the context that mitigated against the policy, but local British officers too, seemed not too keen to adopt it. In Willis's view, British officials at the local level "were extremely skeptical of the efficiency of indirect rule" and viewed the "direct control of the local administration as the only way to ensure local law-enforcement and the collection of tax." ${ }^{, 198}$ In his view, they were more concerned with efficient direct rule than with the restoration or invention of an incompetent indigenous authority. In his study of the administration of Bonde, an area located at the north east coast of Tanzania, he found that introduction of indirect rule and the creation of tribal authorities was resisted for many years by local colonial officials.

\footnotetext{
${ }^{195}$ Iliffe, J.1979. Ibid, p. 319

${ }^{196}$ In one of the best books on the History of Tanzania, John Iliffe (1979) devoted a chapter to the adoption of indirect rule that he titled "The Creation of Tribes."

${ }^{197}$ Willis, J. 1993. "The Administration of Bonde, 1920-60: A Study of the Implementation of Indirect rule in Tanganyika." African Affairs, Vol. 92, p. 53.

${ }^{198}$ Willis, J 1993, Ibid, p. 55.
} 
He asserts that "The history of indirect rule in Bonde would suggest ....the invention of chiefs and the creation of tribes were not considered by the local administration to be effective or efficient adjuncts to the colonial government... the district administration was able for a number of years to avoid not only the invention of a chief for the area, but also the implementation of any meaningful degree of indirect rule."199

In the areas where it was successfully implemented however, indirect rule gave rise to the position of the chief, an intermediary authority that was used as means of social control over the masses. As in Uganda, these chiefs acquired extensive administrative, economic, and legal powers. They collected taxes, recruited labor, presided over and adjudicated disputes, while at the same time catering to their self interest by accumulating wealth in the form of land, cattle, and even wives. In their bid to attain administrative effectiveness and legitimacy, they had to adhere to the colonial directives while at the same time being sensitive to the interests of 'their' people. This was a difficult balance to attain.

It is therefore evident that pre-colonial and colonial contexts in Tanzania are significantly different from Uganda's. The differences played a significant role in shaping the contemporary states' administrative, economic, and political functioning. The next section focuses on the colonial heritage and bureaucratic manifestations in both countries.

\footnotetext{
${ }^{199}$ Willis, J 1993, Ibid, p. 67.
} 


\subsection{COLONIAL HERITAGE AND BUREAUCRATIC DEVELOPMENT IN UGANDA AND TANZANIA}

Recent research indicates that colonialism reversed levels of development in most of the colonies whether in the western world or in Africa, Asia, and Latin America. In some colonies, the reversal was progressive while in others, it was regressive. In particular, the developmental legacies of British colonial rule have come under great scrutiny. ${ }^{200}$ Many of the studies focus on the effects of colonialism on economic development, democratization, and general political development but the major focus of this section will be the colonial legacy and it effects on the post-independence bureaucracy in Uganda and Tanzania.

It has been asserted that the type of colonial system imposed on the colony settlement or extractive, direct or indirect, had a profound effect on the post-colonial developments. According to Acemoglu, Johnson, and Robinson (2001), the different types of colonization policies generated different sets of institutions. On one side are the extractive institutions set up in states like Congo under Belgian rule. They assert that such institutions "did not introduce much protection for private property, nor did they provide checks and balances against government expropriation. In fact, the main purpose

\footnotetext{
${ }^{200}$ See for instance Lange, M., Mahoney J., and Maththias vom Hau. 2006. "Colonialism and Development: A Comparative Analysis of Spanish and British Colonies." The American Journal of Sociology, Vol. 111, No. 5, pp1412-1462; Lange, M. K. 2004. "British Colonial Legacies and Political Development." World Development, Vol. 32, No. 6, pp.905-922; Acemoglu, D., Johnson, S., and James A. Robinson. 2002. "Reversal of Fortune: Geography and Institutions in the Making of the Modern World Income Distribution." The Quarterly Journal of Economics, Vol. 117, No. 4, pp 1231-1294; Acemoglu, D., Johnson, S., and James A. Robinson. 2001. "Colonial Origins of Comparative Development: An Empirical Investigation." American Economic Review, Vol. 91, No. 5, pp 1369-1401; Mamdani, M. 1996. Citizen and Subject: Contemporary Africa and the Legacy of Late Colonialism. Princeton, NJ: Princeton University Press. and Young, C. 1994. The African Colonial State in Comparative Perspective. New Haven, CT: Yale University Press.
} 
of the extractive state was to transfer as much the resources of the colony to the colonizer." 201 On the other side are the settlement institutions set up in states where big numbers of Europeans migrated, settled, and attempted to establish their 'home institutions' in the colonies "with strong emphasis on private property and checks against government power."202 According to Acemoglu et al. (2001), such colonies include Australia, New Zealand, Canada and the USA. In their view, such colonial states and institutions endured through the post-independence period.

Researchers have also argued that the conditions within the colonized country necessitated the establishment of particular institutions. Sokoloff and Engerman (2000) assert that the types of climate, soil, and traditional societies associated with pre-colonial wealth often led the colonialists to establish extractive institutions that in turn led to inequality that persisted to the post-independence era, while those societies that were not as well endowed often escaped the extractive colonial tendencies hence prospered after independence. ${ }^{203}$ Acemoglu et al. (2001) while also focusing on the pre-colonial context, argue that population density and disease prevalence affected colonial policies. In the areas that were sparsely populated and not heavily infested with diseases, the colonialists settled in large numbers and established viable and developmental policies and institutions that upheld the rule of law and encouraged investment, and strong institutions that still prevail. In areas that were densely populated and largely infested with diseases,

\footnotetext{
${ }^{201}$ Acemoglu, D., Johnson, S., and James A. Robinson. 2001. "Colonial Origins of Comparative Development: An Empirical Investigation.” The American Economic Review, Vol. 91, No. 5, p. 1370.

${ }^{202}$ Acemoglu, D., Johnson, S., and James A. Robinson. 2001. Ibid.

203 Sokoloff, K. L. and Stanley, L. Engerman. 2000. "Institutions, Factor Endowments, and Paths of Development in the New World." The Journal of Economic Perspectives, Vol 14, No. 3, pp. $217-232$.
} 
the colonialists "set up extractive states with the intention of transferring resources rapidly to the metropole. These institutions were detrimental to investment and economic progress through the post-independence era. ${ }^{204}$

When analyzed with in the perspective of the above settlement or extractive, direct or indirect dichotomies, and the contexts under which either of them was found to be more favorable and feasible over the other, pre-colonial Uganda and Tanzania easily fall in the category of extractive and indirectly ruled colonial states. Uganda had a high level of pre-colonial political and administrative development and a high population density, while Tanzania had a considerably diseased environment that did not favor European settlement. Indeed at the time of independence the European population in Uganda was less than .1 percent of the national population while in Tanzania it was approximately .3 percent. Table 4.1 below offers a comparative view of the population statistics of the East African countries at the time of colonial penetration.

The numbers indicate that while Uganda had a smaller territory in comparison to its neighboring countries, it had the highest population density and the least number of European settlers.

Scholars contend that there is a relationship between the level of pre-colonial development, the level of colonialism, the population density, and colonial settlement. Table 4.2 offers those variables in three Eastern African countries and three Western former British colonies.

\footnotetext{
${ }^{204}$ Acemoglu, D., Johnson, S., and James A. Robinson. 2001. Ibid, p. 1395.
} 
Table 4.1 Population Statistics of the Three Eastern African Countries at the onset of British Colonialism

\begin{tabular}{|c|c|c|c|c|c|c|c|c|c|}
\hline TERRITORY & STATUS & $\begin{array}{c}\text { YEAR OF } \\
\text { ACQUISITION }\end{array}$ & $\begin{array}{c}\text { SIZE IN } \\
\text { SQUARE } \\
\text { MILES }\end{array}$ & $\begin{array}{c}\text { NATIVE } \\
\text { POPULATION }\end{array}$ & $\begin{array}{c}\text { EUROPEAN } \\
\text { POPULATION }\end{array}$ & $\begin{array}{c}\text { PERCENTAGE } \\
\text { OF } \\
\text { EUROPEANS }\end{array}$ & $\begin{array}{c}\text { ASIAN } \\
\text { POPULATION }\end{array}$ & $\begin{array}{c}\text { TOTAL } \\
\text { POPULATION }\end{array}$ & DENSITY \\
\hline Kenya & $\begin{array}{l}\text { Colony and } \\
\text { Protectorate }\end{array}$ & $\begin{array}{c}(1895) \\
1920\end{array}$ & 219,730 & $3,253,689$ & 16,812 & 0.51 & 57,135 & $3,327,636$ & 15.1 \\
\hline Uganda & Protectorate & 1894 & 93,981 & $3,536,267$ & 2,100 & 0.06 & 18,800 & $3,557,167$ & 37.8 \\
\hline Tanzania & Mandate & 1922 & 360,000 & $5,214,800$ & 9,345 & 0.17 & 33,784 & $5,257,929$ & 14.5 \\
\hline
\end{tabular}

Source: Adapted and modified with small changes from Wieschhoff, H. A. 1972. Colonial Policies in Africa. Westport, CONN:

Negro University Press, p. 10.

Table 4.2 Levels of Pre-colonial Development and Colonialism in a few British Colonies

\begin{tabular}{|l|c|c|c|c|}
\hline COUNTRY & $\begin{array}{c}\text { LEVEL OF } \\
\text { PRE-COLONIAL } \\
\text { DEVELOPMENT }\end{array}$ & $\begin{array}{c}\text { LEVEL OF } \\
\text { COLONIALISM }\end{array}$ & $\begin{array}{c}\text { PRE-COLONIAL POPULATION } \\
\text { DENSITY (PERSONS PER Km) }\end{array}$ & $\begin{array}{c}\text { EUROPEAN POPULATION AT THE } \\
\text { END OF COLONIALISM (\% TOTAL) }\end{array}$ \\
\hline Australia & Low & High & 0.03 & 9.02 \\
\hline Canada & Low & High & 5.71 & 0.7 \\
\hline Kenya & Low & Low-Intermediate & 4.53 & 0.3 \\
\hline Tanzania & Intermediate & Low & 15.22 & $<$ \\
\hline Uganda & High & Low & 0.09 & 81.2 \\
\hline United States & Low & High & & 0.1 \\
\hline
\end{tabular}

Source: Adapted and modified with small changes from Lange, M., Mahoney J., and Maththias vom Hau. 2006. "Colonialism and Development: A

Comparative Analysis of Spanish and British Colonies." The American Journal of Sociology, Vol. 111, No. 5, p. 1434. 
The data in table 4.2 clearly indicate that the population density at the time of colonial penetration in the three East African countries was much higher than that in the Western territories and European settlement much less in the African territories. It is also apparent that of the six countries, Uganda had the highest level of pre-colonial development, a point that reinforces the arguments pointed out earlier. The data also illustrate that the areas which were sparsely populated experienced a higher level of colonialism and hence more settlement which necessitated the application of the rights, privileges, and protection of the metropole, critical elements that were starkly lacking in the African territories. It is evident from table 4.2 that the British tended to pursue higher levels of colonialism and settled more extensively in the sparsely populated pre-colonial societies that also had low levels of pre-colonial development.

Uganda and Tanzania therefore fit quite well in the category of colonies that were ruled indirectly and in which extractive institutions were built by the colonialists as described by Lange et al. and by Acemoglu et al. Moreover, both countries are still poor and developing, a fact that lends credence to the argument raised by Acemoglu et al. that “colonies where Europeans faced higher mortality rates are today substantially poorer than colonies that were healthy for Europeans." 205 The colonialists deemed it expedient that Uganda and Tanzania remain African countries with very minimal foreign settlement. The colonial policies favored a peasant-dominated agricultural economy, minimal investment opportunities, and skeletal institutional development only necessary for the pursuance of colonial ideals.

\footnotetext{
205 Acemoglu, D., Johnson, S., and James A. Robinson. 2001. "Colonial Origins of Comparative Development: An Empirical Investigation.” The American Economic Review, Vol. 91, No. 5, p. 1370.
} 
In spite of the fact that the two East African countries were not extensively colonized in terms of colonial settlement with subsequent replication of European institutions with strong emphasis on private property and checks against governmental power, the British did manage to entrench a considerable number of institutions, economic and political policies, and legal procedures that were to endure into the postindependence period. Indeed, the administrative institutions that were inherited when Uganda and Tanzania attained independence on October 9, 1962 and December 9, 1961 respectively, were in many respects replicas and extensions of the ones utilized previously as instruments of coercion by the British colonial masters. Therefore, the origins of the contemporary Ugandan and Tanzanian administrative systems can be traced to the British colonial service. Moreover, some of the maladies that have affected the civil service performance have their roots in the colonial civil service and its operation.

The British Colonial Service bureaucracy, later named Her Majesty's Overseas Service, administered the East African territories with a highly elaborate and hierarchical structure of roles. Procedures for dealing with local masses, with Europeans, and with Asians were specified, as were processes of recruitment into the bureaucracy. The colonial civil service, an instrument of the British imperial policy of indirect rule, was mainly concerned with the maintenance of law and order, the collection of taxes, and the provision of the necessary framework for trade in the colony. It was not required to deal with complex issues of the present day administration like formulation of developmental economic and political policies, because such functions were not the immediate rational reasons for acquiring the colony. 
The British established a highly stratified civil service system in which they occupied all the administrative and professional positions, the Asians most of the executive and a few professional positions, and the natives the clerical, secretarial, and generally other subordinate positions. The entire administrative system was designed by the British to serve their own interests and its main task was to extract as much wealth as possible by enforcing law and order and by collection of taxes. According to Rweyemamu and Hyden (1975), "the public administration system was neither responsible nor responsive to the will of the people." ${ }^{206}$ Boahen (1987) while assessing the nature of colonialism in Africa, states the goal of the colonial administration in stronger terms when he asserts that "Its main raison d'être ${ }^{207}$ was the ruthless exploitation of human and material resources of the African continent to the advantage of the owners and shareholders of expatriate companies and the metropolitan governments and their manufacturing and industrial firms." 208

Administratively, Uganda was divided into four provinces namely the Eastern, Northern, Western, and Buganda all headed by a Provincial Commissioner. The provinces were further divided into districts headed by the District Commissioner aided by an assistant district commissioner and some clerical staff. The districts were themselves divided into counties (Sazas) and sub-county units (Gombololas) and parishes (Mulukas) presided over by the "native" civil service chiefs. All civil servants were

\footnotetext{
${ }^{206}$ Rweyemamu, A. and Hyden, G. 1975. A Decade of Public Administration in Africa. Nairobi: East African Literature Bureau p. 32.

${ }^{207}$ Emphasis his own.

${ }^{208}$ Boahen, A. A. 1987. African Perspectives on Colonialism. Baltimore: The Johns Hopkins University Press, p. 62.
} 
directly answerable to the Governor who was appointed in England. Below him were the Provincial Commissioner and District Commissioner both Crown appointees and it was the District Commissioner that supervised the chiefs and whose supervisory role extended "to the conduct of every minor official down to the village clerk or constable. ${ }^{209}$ The colonial civil service therefore was highly centralized with very few elements of deconcentration. According to Burke (1967), "The colonial bureaucracy possessed a near monopoly of power in the African territories. Broadly defined directives emanated from the Colonial Office in London (or its equivalent in Paris, Brussels or Lisbon), but the administrative hierarchy, with Governor at the apex and the native chiefs, headmen or functionaries at the base, formulated and executed actual administrative policy. ${ }^{210}$ Since the major role of the civil service was the maintenance of law and order and collection of taxes, the administrative system that was instituted was highly legalistic, emphasized loyalty, processes, procedures, and precedents. ${ }^{211}$ The colonial civil service therefore was highly conservative and hierarchical. It repressed lower-level participation in decision making, was unresponsive, and not geared towards the development of the country.

Prior to independence, in the period 1940-50, the colonial administration made efforts to alter the orientation of the civil service and hastened to train the natives on

\footnotetext{
${ }^{209}$ Uganda Protectorate. (1939). Native Administration: Note by the Governor. Entebbe: Government Printer, p. 5.

${ }^{210}$ Burke, F. G. 1967. "Public Administration in Africa: The Legacy of Inherited Colonial Institutions" Paper presented at the World Congress of International Political Science Association, Brussels, Sept. 18-23, p.1.

${ }^{211}$ Mutahaba, G. and Baguma, R. and Halfani, M.1993. Vitalizing African Public Administration for Recovery and Development. West Hartford, CONN: Kumarian Press, Inc., p. 7.
} 
matters of administration. According to Burke (1967), the colonial bureaucrats "conceived of their task as one of passing on an established body of knowledge concerning those routines, procedures, and rules which they had successfully employed to rule Africans who were about to take over the reins of the state."212 What the colonialists seem to have forgotten however is the fact the above mentioned body of knowledge was used to subjugate and exploit the natives, functions that would not favor the pursuit of national welfare and development in the post-independence era. The onus was therefore on the newly independent natives to modify or do away with those rules, routines, and procedures. But as illustrated in the pages ahead especially in the case of Uganda, no fundamental change occurred. Rather, the post-independence political leadership not only operated an inherited colonial system of government and administration but also unwittingly embraced it even as it propelled them along a course quite contrary to the demands of nation building.

The British, also, made efforts to upgrade and change the terms and conditions of the civil service by setting up commissions like the 1947 Holmes Commission in Uganda whose task was to review the structure, appointment, and pay systems of the civil service. Among others, the commission recommended that all positions with in the civil service be opened to all qualified persons from all races in order to have equity. ${ }^{213}$ In 1955 , the Public Service Commission was established to advise the Governor on the civil service

\footnotetext{
${ }^{212}$ Burke, F. G. 1967. "Public Administration in Africa: The Legacy of Inherited Colonial Institutions." Paper presented at the World Congress of International Political Science Association, Brussels, September $18-23$, p. 6.

${ }^{213}$ Rweyemamu, A. and Hyden, G. 1975. A Decade of Public Administration in Africa. Nairobi: East African Literature Bureau.
} 
matters and to oversee the appointment into and promotion in the civil service. Therefore, civil service positions were opened up to the educated elite based on the principle of meritocracy. According to Karugire (1996):

"It was through the medium of the Public Service Commission that a strong and reasonably impartial Civil Service was built in Uganda. This was self-evident at the time of independence, when the Public Service Commission's advisory role to the Governor was changed and it was made an independent executive body in the discharge of its functions...... After independence, the Ugandan civil service was able to attract and retain the country's best trained manpower." 214

In Tanzania, an efficient civil service of African administrators and clerks emerged but resulted in divisions within the society as identities and loyalties shifted. It has been argued that colonial policies in Tanzania generated parochial tendencies that were not existent in the pre-colonial period. According to Iliffe (1979) it is during the colonial period that Tanzanians began to think of themselves as being "Muslim or Christian, Protestants or Catholics, clerks or workers, African or even Tanganyikans.”215 Moreover, socio-economic change generated by colonial rule exacerbated the situation as circumstances determined which identity was emphasized for instance "men deeply involved in colonial society formed the Tanganyika Territory African Civil Services Association, while the deprived often stressed parochial identities."216

At independence, the Ugandan civil service was considered one of the best in Sub-Saharan Africa. ${ }^{217}$ It was small, well paid, efficient, motivated, quite neutral and

\footnotetext{
${ }^{214}$ Karugire, S. R. 1996. Roots of Instability in Uganda. Kampala: Fountain Publishers, p. 32.

${ }^{215}$ Iliffe, J.1979. Op Cit, p. 318.

${ }^{216}$ Iliffe, J.1979. Ibid, p. 318.

${ }^{217}$ See Karugire, S. R. 1996. Ibid.
} 
ethical. Others have argued that at independence, Uganda had "a lively and free press (soon eliminated), a good university (which became embattled), and an excellent civil service cum political administration (slowly undermined), which linked the central government with provincial, district, county, and other more local jurisdictions.."218 However, it has been argued that despite such great attributes, the civil service "was devoid of cultural attributes, shared values, and historical traditions which were inherent in the Westminster model. It was an artificial institution which did not have any solid social foundations." ${ }^{219}$ It was therefore not long before the Weberian ideals of loyalty, cohesion, and dedication to duty were abandoned falling prey to the inexperience of the native civil servants and cultural context that fostered nepotism and patronage instead of meritocracy.

After independence, the Africanization ${ }^{220}$ policy was introduced in most of Africa. Native Ugandans and Tanzanians replaced the Europeans and other foreigners. Even when there was a desperate lack of suitable local replacement, the trained foreign personnel were relieved of their duties. Africanization policy was implemented in most former British colonies. Heady cites a Nigerian as giving the understandable reasons for such a policy:

The decision was taken by our leaders that the British officials should be replaced, not because they hated or distrusted them, but because they felt that political independence was a sham unless you had also a great measure of administrative

\footnotetext{
${ }^{218}$ Apter, D. E. 1995. “Democracy for Uganda: A Case for Comparison.” Daedalus, Vol. 124, No. 3, p.160.

${ }^{219}$ Langseth, P. and Justus Mugaju. 1996. Post-Conflict Uganda: Towards an Effective Civil Service. Kampala: Fountain Publishers, p. 3

${ }^{32}$ Africanization is a term used to refer to the process of indigenization of the civil service and other sectors of government.
} 
independence. You just could not be politically independent and remain administratively dependent, over a long period, without misunderstanding and tensions arising between the expatriate administrator and his indigenous political master. ${ }^{221}$

It is fair to say then, that replacing the British with the natives soon after independence was a political requisite albeit dysfunctional from an administrative and economic point of view. Interesting to note however is the fact that the civil service structures were left fundamentally unaltered. The beneficiaries of the "Africanization" policy saw no shame in arguing for the retention of the privileges and characteristics associated with the colonial structure for instance the criteria for selection to higher civil service positions placed a major emphasis on the command of English and on a modern western education. According to Burke (1967), "Africanization did not normally entail significant alteration in role definition, but rather that indigenous Africans were substituted for expatriate Europeans in roles already well-defined and already possessed of an established status and a highly routinized set of procedures." He reinforces what has been pointed out above when he argues further that "these inherited roles, procedures and rules were not designed to achieve the goals of the newly-established polity, but rather worked to perpetuate a pre-existing distribution of values." ${ }^{, 22}$ It can therefore be asserted that the post-independence civil service 'started on the wrong footing' since the colonial administrative system was a static structure aimed at the maintenance of law and order and collection of taxes. The post-independence bureaucracy envisaged by native elite and

${ }^{221}$ Heady, F. 2001. Public Administration: A Comparative Perspective. New York: Marcel Dekker, Inc, p. 301.

${ }^{222}$ Burke, F. G. 1967. "Public Administration in Africa: The Legacy of Inherited Colonial Institutions." Paper presented at the World Congress of International Political Science Association, Brussels, September 18-23, p. 22. 
politicians was a dynamic system of administration charged with managing rapid economic, political, and social change while at the same time evolving new forms of bureaucratic processes and procedures. Yet, partly because the institutional fiber was still colonial in nature and especially because of authoritarian politics, the post-independence efforts faltered and fell short of realizing the independence ideals.

Another major legacy of the colonial administration is the politicization of the civil service. Under colonial rule, administrative positions were highly politicized, and this trend carried on after independence. The power structure during the colonial era was hierarchical, centralized, and controlled from above right from England, to the Governor, the Provincial Commissioner, District Commissioner, and finally to the local chief. Within the colony, the governor, provincial and district commissioners, monopolized the powers of hire and fire, allocated roles and responsibilities, and functioned in the framework directed to them from the colonial office in London. For instance, The Administrative Instructions issued by the Protectorate Government in 1940 directed that: "The Provincial Commissioner is, within the limits of his province, the principal executive officer of government and is personally and directly responsible to the Governor for the peace and good order of the his province and for the efficient conduct of all public business therein."223 It was further instructed that the Provincial Commissioner had power to issues orders and directives to any officer serving in the province "preferably by word of mouth." "224 If an emergence arose, the Provincial Commissioner

\footnotetext{
${ }^{223}$ Uganda Protectorate. 1940. Administrative Instructions. Entebbe: Government Printer, p. 1.

${ }^{224}$ Uganda Protectorate 1940. Ibid, p. 1.
} 
had powers to act as "the sole judge" and to issue orders "which must be carried out by the recipients without delay." 225 The District Commissioners enjoyed similar powers, authority, and general control over the functioning of district matters. Instructions of this nature illustrate that the level centralization in the administrative structure was very high. Central control greatly constricted the local administration, leaving little room for local participation and initiative.

According to Burke (1967), "It is important to keep this fusion of the administrative and political functions in mind when considering the tendency of contemporary African politics to 'politicize their administration.' For this trend should be viewed less as a departure from the metropolitan model than as a return to familiar system."226 Indeed, the post-independence civil service retained the highly centralized and hierarchical structure. The power structure started from Kampala and Dar es Salaam the capital cities for Uganda and Tanzania respectively where rules, regulations, roles, and responsibilities were allocated downwards. All government departments (ministries) had their headquarters in the two cities and were headed by ministers that were politically appointed. Districts and other lower levels of administration got directives from the center. The minister, based in Kampala/Dar es Salaam, had powers to hire and fire anyone at the local levels of the administration, and had the powers to determine the membership, constitution, and regulations of the local appointments board. The centralizing tendencies were entrenched in the political and administrative fiber of the

\footnotetext{
${ }^{225}$ Uganda Protectorate 1940. Ibid, p.1.

${ }^{226}$ Burke, F. G. 1967. Ibid. p. 22.
} 
new state via various official documents. For instance, the post-independence Local Administrations Ordinance enacted in Uganda in 1962 clearly placed the powers of recruitment and regulation of local government staff in the hands of the central government. $^{227}$ Burke (1964), amazed at the level of post-colonial centralization in Uganda commented that "The powers of the central government over local staff appointment, tenure, and functions is greater than at any time since the introduction of modern local government.",228

Native authority also became highly politicized with the introduction of the position of the chief into the colonial bureaucracy. Where as the colonial administration personnel was generally recruited and employed along bureaucratic lines, the positions held by the chiefs were rooted largely in patrimonialism for they were accorded administrative positions based on their lineage in the traditional kingdom areas, and most importantly they were appointed principally based on their willingness to collaborate with the colonial officials. The Ugandan 1919 Native Authority Ordinance enumerated the powers and duties of the African Chiefs and the manner in which they could enforce authority. The duty of the chiefs was specified as that of maintaining "order in the areas within which he has jurisdiction." ${ }^{229}$ Under this ordinance, the chiefs were accorded powers to prevent crimes, to arrest offenders, to prohibit natives from carrying arms, and to ensure that the natives provide compulsory and free labor for public ventures. These

\footnotetext{
${ }^{227}$ Uganda Government. Local Administration Ordinance 1962. Entebbe: Government Printer.

${ }^{228}$ Burke F. G. 1964. Local Government and Politics in Uganda. Syracuse: Syracuse University Press, p. 47.

${ }^{229}$ Uganda Protectorate. 1936. An ordinance to Make Provision for the Powers of and Duties of African Chiefs and for the Enforcement of African Authority. Laws of Uganda, Chapter 72.
} 
chiefs were granted wide-ranging powers over the native Ugandans and their authority and orders prevailed over the native laws and customs except in Buganda where the 1900 Agreement ensured that the Kingdom retained some form of independence. Mair (1977) argues that the colonial administration had to limit the native chiefs' authority and impose strict rules for its exercise. Hence the chiefs became responsible to a government above and beyond their own traditional ruler, and were expected to interfere in all kinds of ways in the lives of the natives. Inevitably, their relations with the native population changed in numerous ways. ${ }^{230}$

It should also be noted that the chiefs were accountable only to the British District Commissioner. According to Burke (1964), the 1919 Native Authority Ordinance "gave the chiefs of Uganda - both those possessed of traditional authority and those superimposed over clan or age-group societies - a degree of authority which greatly exceeded anything they held traditionally. Backed by the power of the colonial government in the guise of the District Commissioner, the chief's powers of arrest and seizure, and control over the allocation and use of property were nearly unlimited."231 The worst case of politicization of the chieftainship was in the non-kingdom areas of northern and eastern Uganda. In those places, the chiefs were not restrained by the accountability of traditional societies' norms and values found in the Kingdom areas hence the chiefs became highly autocratic with a fusion of powers of arrest, judgment, and punishment. Mamdani (1996) however argues that even in the kingdom areas,

\footnotetext{
${ }^{230}$ Mair, L. 1977. Primitive Government: A Study of Traditional Political Systems in Eastern Africa. Bloomington, IND: Indiana University Press.

${ }^{231}$ Burke, F. G. 1964. Ibid, p. 34.
} 
traditional constraints on the chiefs were eroded by colonialism. He asserts that "By undermining both popular (clan) checks on state authority and traditional constraints as embodied in traditional chiefs, the colonial state really liberated administrative chiefs from all institutionalized constraint, of peers or people, and laid the basis of a decentralized despotism.",232

According to Lange (2004), indirect rule in African British colonies bestowed on the chiefs great institutional powers - customary law powers, executive, judicial, and legislative powers. Such powers, in his view, "were augmented by their intermediary positions, which enabled them to control information and resource flows between the colonial administration and the local populations and avoid colonial supervision... Their intermediary position allowed chiefs to be rent-seekers extraordinaire whenever exchanges between the administration and local population occurred."233 Indeed by independence, chiefs were in complete isolation from 'their' people and were generally perceived as servants of an external government. In Tanzania, the scenario was not much different. According to Spear (2005), "chiefs grew in wealth, influence and powers as they became wealthy in cattle, rich in land, and patriarchs of large families. Sambegye had ten wives and Sabaya fourteen. Able to distribute cattle and wives to others, they also became powerful patrons with expanding numbers of clients."234

\footnotetext{
${ }^{232}$ Mamdani, M. 1996. Op Cit, p. 43.

${ }^{233}$ Lange, M. K. 2004. "British Colonial Legacies and Political Development." World Development. Vol. 32, No. 6, p. 907.

${ }^{234}$ Spear, T. 2005. Ibid, p. 76.
} 
A few years to independence, the colonial government initiated deliberate policy changes and reforms to increase native participation in both the political and administrative processes. These reforms were enshrined in a confidential dispatch from the British Secretary of State for the Colonies Mr. Creech-Jones of February 251947 to the Governors of the African Territories. In that dispatch, he underscored the need to develop a "local", "efficient", and "democratic" system of administration by asserting that "Local because the system of government must be close to the common people and their problems, efficient because it must be capable of managing the local services in a way which will help to raise the standard of living, democratic because it must not only find a place for the growing class of educated men, but at the same time command the respect and support of the mass of the people. ${ }^{235}$ This appears to be a call for radical alterations in the colonial policies. Indeed, reforms were put in place among them, the Local Government Ordinance of 1949 that legalized and granted corporate powers and responsibilities to local district councils and the District Administration Ordinance of 1955 that was subsequently amended in 1959 . The ordinances however did not attain much in the way of administrative reform and did not meet the call made by the Secretary's dispatch. For instance, although local councils were authorized, their laws and functions were subject to the approval of the Governor. The chiefs continued to be instruments of colonial rule, appointed and accountable to the Governor, they retained legislative, executive, and judicial powers; the district commissioner powers were not

\footnotetext{
${ }^{235}$ Emphasis mine. Cited from Burke, F. G. 1964. Ibid p. 38.
} 
pruned, and the general bureaucratic structure remained intact in spite of the 1955 and 1959 amendments.

Mair (1977) asserts that "In the Uganda kingdoms, the bureaucratic system of territorial administration, with its pyramid of chiefs ... was maintained after independence. It was they, therefore, and not the kings, who bore the brunt of such unpopularity as new requirements might provoke." 236 At independence, the powers of the chief were slightly reduced and he was made accountable to both the central government and local governments. However, the Local Administration Act of 1967 revived and entrenched the powers of chief. The chiefs were used to tighten the hold of the central government on the ordinary people as their powers enumerated in the Act Section 40 illustrate: “... to detect and bring offenders to justice and to apprehend all persons whom he is legally authorized to apprehend... he may without warrant, enter at any hour of the day or night any place in which he has reasonable grounds to suspect that illegal drinking or gambling is taking place, or to which dissolute or disorderly behavior are resorting.",237 It is evident that the powers given to the post-independence chief far exceeded those of his colonial predecessor as he appears to have become a law unto himself. Indeed the chief's powers far exceeded any law governing the bureaucracy because no other law authorized any public officer to act in a similar manner without check. Just like in the colonial period, the chief was used by the Local Government Minister to implement unpopular policy and suppress the masses. Mamdani (1996) makes the same point when

\footnotetext{
${ }^{236}$ Mair, L. 1977. Primitive Government: A Study of Traditional Political Systems in Eastern Africa. Bloomington, IND: Indiana University Press, p. 232.

${ }^{237}$ Uganda Local Administration Act 1967. Entebbe: Government Printer.
} 
he asserts that the independence reforms did not weaken the chiefs but entrenched the colonial system of "decentralized despotism" which undermined administrative efficiency and development goals. ${ }^{238}$

In Post-independence Tanzania, politicization of the civil service and native authorities was enhanced further by the adoption of the single political party system. The upper echelon of the bureaucracy was largely filled by persons long on party service and loyalty but frequently short on education and experience. It was also not uncommon for skilled and experienced bureaucrats to be brought into the political arena when appointed into political positions as junior ministers or party branch chairmen. According to Burke (1967), "It was not long after independence that many in the civil service realized that bureaucratic advancement "is often as difficult as it was before independence. The major positions to which the bureaucrat's education, experience, and energy led him to aspire are more and more filled by young, non-educated, inexperienced, and often corrupt revolutionary leaders." 239 Yet in adopting a single party system, Tanzania was trying to break away from the colonial shackles and trying to unify the country. For instance while in Uganda the hierarchy of local state apparatus from the district commissioner to chiefs and headmen was retained, in Tanzania the reverse occurred. The district commissioner was replaced by a politically appointed official from the party cadres, the position of the chief was abolished, and a single customary law surpassing tribal boundaries was

\footnotetext{
${ }^{238}$ Mamdani, M. 1996. Citizen and Subject: Contemporary Africa and the Legacy of Late Colonialism. Princeton, NJ: Princeton University Press.

${ }^{239}$ Burke, F. G. 1967. "Public Administration in Africa: The Legacy of Inherited Colonial Institutions." Paper presented at the World Congress of the International Political Science Association, Brussels, Sept. $18-23$, p. 31
} 
adopted. Most notable, in Tanzania, the new office bearers did not enjoy a fusion of power as they predecessors had. Unlike the colonial chiefs, they did not have power to enact laws or to adjudicate legal matters. Mamdani (1996) however is not impressed by the reforms. In his view, post independence Tanzania's quest to reform the decentralized despotism left in place by the British "reorganized decentralized power so as to unify the "nation" through a reform that attended to centralization. The antidote to a decentralized despotism turned out to be a centralized despotism.",240

Generally, when compared to Uganda, Tanzania seems to have appreciated the absence of a 'fit' between inherited administrative and political systems and the newly formulated independence goals and ideals. It proceeded to dismantle the colonial administrative structure and build a new one based on what came to be known as African socialism, ${ }^{241}$ a system that emphasized equality, mass participation, national integration, and development; and to adopt a one party political system. Yet, both political leaders and civil servants emulated and perpetuated the colonial life style. Burke (1967) illustrates this heavy contradiction by asserting that in Tanzania

"where every attempt has been made to build the new nation on a bedrock of a revived African culture, and according to the tenets of African socialism, the head of state has inherited the Governor's palace, his upcountry lodges and other physical amenities symbolic of authority and status. In greater need of powerful symbols of authority for along-suppressed self-esteem and for purposes of acquiring mass legitimacy, the new elite is inclined towards greater ostentatiousness than its predecessor.", 242

\footnotetext{
${ }^{240}$ Mamdani, M. 1996. Op Cit, p. 25.

${ }^{241}$ African Socialism is discussed in depth in chapter 6 ahead.

${ }^{242}$ Burke, F. G. 1967. Ibid, p. 40.
} 


\subsection{SUMMARY}

Chapter four has illustrated that precolonial Uganda had an intricate administrative system based on the traditional tribes and kingdoms and that the colonial governments utilized the pre-existing structures to administer the colony. In places where such were missing as in northern Uganda and much of Tanzania, they were created. It has been shown that the colonial legacy has had great influence on the functioning of the post-independence administrative institutions in Uganda and Tanzania. The new leaders faced the arduous task of establishing national unity and advancing socioeconomic development, but with little precedent to aid them, opted to uphold the colonial institutions in Uganda, and attempted to reform them in Tanzania. Burke (1967) argues the same point when he asserts that "It was problematically evident that the leaders of the new African states faced the difficult task of establishing a sense of unity and identification and, in the process, re-legitimizing old, and legitimizing new sets of political and administrative institutions, with little precedent to assist them. Nation building, of course also meant employing these new institutions to systematically and rapidly bring about radical social and economic change." 243 Yet, in reality, neither did manage to effectively sustain the colonial structure and institutions, nor imaginatively frame administrative models capable of absorbing and facilitating the new expectations of the Ugandan and Tanzanian populace after independence.

The fact that the British colonial legacies affected the post-colonial bureaucracy cannot be denied. Indeed, the inherited colonial bureaucratic structures strongly

\footnotetext{
${ }^{243}$ Burke, F. G. 1967. Op Cit p.2.
} 
influenced the pursuit of newly defined goals. The major challenge of the neophyte Ugandan and Tanzanian administrative elite therefore was to adjust an already hybrid model to cope with new and additional demands, a challenge that was met only abysmally as chapter five ahead illustrates. Burke (1967) put it succinctly when he wrote thus;

"what alternatives are available to the African bureaucrat faced with the omnipresence of inherited political and administrative institutions powerfully reinforced by an inherited ecology? Three alternatives pertain: one "is corruption and other forms of deviation so that the demands of the system can be met - so that the new role carriers can secure the resources necessary to maintain the establishment in a style to which it is accustomed", second, is "the general acceptance of most elements in the system and its ecology, including status and class distinctions." Third, "requires the formulation of a new ideology, demanding vigorous redistribution of existing values and even at great sacrifice and risk to the regime, the radical transformation or dismantlement of the system and its supporting ecology.",244

The discussion presented has made it clear that Uganda opted for the first and second options while Tanzania adopted for the third. Chapter five ahead assesses the impact of those choices on the political economy and administrative stance of the countries. It is important to assess the effect of political and economic choices made because they greatly impacted the functioning of the administrative system.

${ }^{244}$ Burke, F. G. 1967. Op Cit, p. 44. 


\section{CHAPTER 5: STATE COLLPSE IN UGANDA AND ECONOMIC STAGNATION IN TANZANIA}

\subsection{INTRODUCTION}

Historical and contemporary analysis of the administrative, socio-economic, and political developments in Uganda reveal what Low (1991) termed as a "dislocated polity." ${ }^{245}$ The development of Uganda's political history has been a volatile one and the main cause of the administrative, economic, and social maladies that the country has endured overtime is political instability. Whereas British colonial rule created a mixture of direct oppression and a semblance of administrative and political order under the policy of indirect rule as illustrated in chapter four, the post-colonial state in Uganda for the most part, has been characterized by brutality, chaos, dictatorship, economic upheaval, social disorder, and collapse of the administrative, economic, social, and political institutions.

In contrast to post-independence Uganda which has suffered great political strife and economic decay, post-independence Tanzania has overall enjoyed political stability. According to Kithingi Kiragu (1999), the country is considered to be one of the most stable nations in Africa. ${ }^{246}$ Tanzania's stability is largely credited to the country's first president, Julius K. Nyerere, who encouraged and nurtured ethnic cohesion, a homogeneous language, and smooth political leadership transitions. However, to say Tanzania is Africa's peace nest would be to stretch the reality. Tension between the

\footnotetext{
${ }^{245}$ Low, D. A. 1991 “A Dislocated Polity: Uganda 1960-86” in Low, D. A. Eclipse of Empire, Cambridge: Cambridge University Press. Low argues that the prospect of building a united and integrated Ugandan nation since colonial times through the post-colonial period has eluded the country's leaders.

${ }^{246}$ Kiragu, K. 1999. “Tanzania” in Public Administration in Africa: Main Issues and Selected Country studies. Ladipo Adamolekun ed. Boulder, Co: Westview Press.
} 
mainland and the Zanzibar islands has been building and the last few elections have seen it escalate to near chaos. Most importantly though, the country has suffered one of the most biting economic stagnation resulting from socialist economic ideology and policies enshrined in what is commonly known as "African Socialism."

Chapter five offers a historical account of the national political malaise that affected the development and functioning of post-independence Uganda. It addresses the effect of the colonial legacy on post-independence politics, and illustrates how political decay, and economic stagnation engineered by the Obote and Idi Amin regimes had profound effects on the functioning of the civil service. A discussion of reforms attempted to reverse the conditions is offered, and the contextual description of the civil service reform program is addressed. In addition, it offers a retrospective look at the political-economic developments in post-independence Tanzania. Focus is placed on the factors that led to economic stagnation namely Ujamaa socialism, villagization, and the quest for self-reliance. A discussion of how the ensuing crisis affected the civil service is offered, and the ways that were adopted to rectify the situation are discussed. The chapter shows that the CSRP is part of the wider SAPs reform efforts that were undertaken to revamp the dire economic state of affairs.

\subsection{UGANDA'S POLITICAL HISTORY: FROM INDEPENDENCE TO STATE COLLAPSE}

When Uganda attained independence on October 9, 1962, the government was guided by a written constitution drafted during the pre-independence negotiations between the British colonial masters and members of Ugandan political parties and other elite. Like the administrative structures, the political structures were also molded against 
those of the British with the head of government designated Prime Minister and the head of state (president) the Kabaka who was the king of the Buganda Kingdom. Whereas this arrangement works quite well for the British, it would not work for the new Uganda. Many reasons account for this discordance. Uganda was an artificially created country without a shared language or a shared historical growth. At independence, the lack of national cohesion was manifest in the different political societal entities that made up the country - kingdoms, non-kingdoms, and districts and the political fissures that manifested along religious and tribal lines. To complicate matters further, the country opted for a federal constitution which accorded one regional kingdom, Buganda, separate and significant powers. The Kingdom controlled its own public services and local government, had powers of taxation, had its own police force, and elected its representatives to the National Assembly through its own mini parliament (the Lukiiko) rather than through a popular vote.

While Buganda enjoyed her considerable autonomy, the other kingdoms in the southwest and eastern parts of the country were accorded semi-federal status and the rest of the non-kingdom areas fell under the central government rule. It should be kept in mind that at independence, Buganda was not only the seat of the government, but also the economic hub of the country. Consequently, the kingdom viewed its officious status as warranted. Apter (1995) illustrates that "the Baganda were not willing to settle for less than a dominant place in the political system. Buganda...... was home to most of the country's elites. It was economically the most prosperous part of the country, the most educated, with the best university in Africa, the capital (Kampala), and its own 
parliament." 247 As a result, it was not politically and economically expedient to antagonize it, rather, effort was made to indulge its uniqueness by offering it great autonomy.

The effect of the independence set up was the emergence of two states in one country - Buganda and rest of Uganda. The former because its federal status accorded it privileges that are tantamount to those of a nation-state, and its leader assumed a nationwide leadership position and the latter by encompassing all of Uganda. This political configuration proved untenable. The Buganda King and his people did not embrace the concept of a ceremonial president subordinate to the Prime Minister especially when the latter belonged to the people who during colonial rule were regarded as subordinate. Calls for Buganda to secede grew louder and louder while outside Buganda, the rest of the country was disenfranchised by the unequal status enjoyed by the kingdom and ultimately came to detest its selfishness and parochialism. The Prime Minister (Apollo Obote) too, found it increasingly difficult to govern as power struggles between him and the Buganda kingdom heightened.

Prior to independence, various political parties were formed to 'champion' the independence movement. According to Mamdani (1976), "not one of these parties was able to emerge and capture the leadership of the independence movement: nationalist parties vied for support against parties that were tribal or religious in their ideological

\footnotetext{
247 Apter, D. E. 1995. "Democracy of Uganda: A Case for Comparison.” Daedalus, Vol. 124, No.3, pp. 156-157.
} 
orientation. ${ }^{248}$ It can be argued that it was not only because the parties were based on tribal and religious affinities that they failed to capture the national independence movement, but because there were no real national issues on which to build a uniform national agenda. Each of the different parts of the country had its own unique issues that it sought to attain and the parties went about advocating whatever issues were of concern to whichever area they sought support in. Four major political parties are worthy of mention here; the Uganda National Congress (UNC), the Uganda People's Congress (UPC), the Democratic Party (DP), and the Kabbaka Yekka - King Only (KY).

Uganda National Congress, the oldest Ugandan political party, was formed in March 1952 and it was predominantly Protestant and heavily made up of the Baganda from Buganda kingdom. The DP was formed in 1956 and its membership was comprised of Catholics and many Baganda as well. The UPC, formed in March 1960, was made of up of renegades from the UNC and while dominated by protestants, was essentially an anti-Buganda/Kabaka, political party. According to Kasozi (1994) its goal was to "address the challenges of Buganda subnationlism and Baganda dominance in an independent Uganda." 249 Karugire (1996) concurs by asserting that, "the UPC was specifically an anti-Buganda party right from its inception and this was to remain throughout its history." 250 The KY was formed in June 1961 "in Buganda to protect the

\footnotetext{
${ }^{248}$ Mamdani, M. 1976. Politics and Class Formation in Uganda. New York: Monthly Review Press, p. 205 .

${ }^{249}$ Kasozi, A. B. K. 1994. The Social Origins of Violence in Uganda, 1964-1985. Montreal: McGillQueen's University Press, p. 60.

${ }^{250}$ Karugire, S. R. 1996. Roots of Instability in Uganda. Kampala: Fountain Publishers, p. 45
} 
Kabaka's and Buganda's position in an independent Uganda. ${ }^{251}$ It can therefore be concluded from the above that Uganda's political parties were not formed to advocate and advance a specific national ideology, but rather, were formed based on narrow tribal and religious loyalties. This was the first hint of the political factionalism that would plague the country for years to come.

When the first national direct elections were held in 1961, they were won by the DP notably because the majority of the Baganda boycotted them in protest against what they considered anti-Buganda sentiments, but the DP managed to mobilize the Catholics from all over the country and some Baganda to hand it a majority in the preindependence Legislative Council. Consequently, the first Ugandan native Prime Minister was to be a Catholic. The UPC and Buganda kingdom did not take kindly to the turn of events and started scheming for ways to change the status quo. According to Ugandan historian Karugire, a Ugandan Prime Minister of the Catholic faith "was a stunning shock to the Kabaka's government and the entire Protestant establishment in Uganda.....The Kabaka's government was the most enduring and visible part of the Protestant hegemony in Uganda but also was the UPC...the prospect of relinquishing power to a Catholic dominated party was an intolerable one to both the UPC and to the Kabaka's government. ${ }^{, 252}$ The British too, were not comfortable with a Catholic national leadership leading them to decide that another general election be held prior to granting self rule "on the seemingly reasonable grounds that Buganda had not meaningfully

\footnotetext{
${ }^{251}$ Karugire, S. R. 1996.Ibid, p. 47.

${ }^{252}$ Karugire, S. R. 1996. Op cit, p. 46
} 
participated in the elections of March 1961."253 It is at this critical juncture that the KY party was formed to advance the Buganda kingdom's interest.

To ensure the fruition of their common cause - defeating the Democratic Party the UPC and the newly formed KY entered what has come to be known as the "unholy alliance." The alliance entailed a plan to side with each other and take similar positions in the pre-independence conference that was to be held to frame the country's constitution. According to Karugire (1996), "the political party whose foundation was specifically an anti-Buganda was now entering into partnership with Buganda leadership just as the British were burning their files and packing their bags to depart." He adds, "the only explanation for this otherwise inexplicable partnership was the common denominator of the Protestant faith, so that beyond ousting the DP from office before granting of independence the UPC and the KY had nothing in common, the two parties being essentially antagonistic." 254 The DP was defeated winning only 3 votes out of 68 but its very existence was not totally shattered as was soon to happen to the Buganda kingdom. Indeed, soon after independence the alliance collapsed.

The unholy alliance that ushered in the Kabaka Presidency and the Milton Obote Premiership fell apart in 1964 when Obote in accordance with the new constitution called for a referendum that the British had tactfully postponed to the post-independence era. The goal was to decide whether the "lost counties" that the British had stolen from Bunyoro kingdom and given to Buganda kingdom, should stay in Buganda, or go back to

\footnotetext{
${ }^{253}$ Karugire, S. R. 1996. Ibid.

${ }^{254}$ Karugire, S. R. 1996. Ibid, p. 47.
} 
Bunyoro or join with the rest of the country as a district under the central government. Not surprisingly, Buganda was against the referendum and attempted influence peddling but ultimately, the counties opted to return to Bunyoro and in so doing, confirmed "that Ugandans did not regard themselves as a people of one country but as essentially belonging to their parochial and sometimes hostile local government units."255

From then onwards the unholy alliance quickly disintegrated and the situation evolved from bad to worse culminating in the 1966 crisis. It is then that Obote abrogated the independence constitution and enacted his own which gave him executive powers and turned Uganda into a unitary state. He abolished kingdoms and unleashed military force led by Idi Amin to oust the Kabaka of Buganda who was lucky to escape unhurt and flee to Britain. It was at this time in Uganda's political history that the military was directly placed into the post independence political arena. Like the colonialists, Obote used the military as a repressive and coercive instrument of the state charged with ensuring compliance with state directives. Once the precedent was set, the post-independence military of the subsequent regimes became heavily politicized, built around personalities with total disregard to democratic institutional development.

Uganda's post-independence military exhibited quite early divided loyalties and manipulative tendencies. While the colonial government army was predominantly composed of northerners - the Langi and Acholi, on assuming power, Obote enhanced the number of his kinsmen, the Langi, and promoted them to sensitive positions. After realizing his own worth after the 1966 crisis, Amin set about recruiting men from his own

\footnotetext{
${ }^{255}$ Karugire, S. R. 1996. Ibid, p. 52.
} 
tribe - the Kakwa - thereby creating a personal army within the national army. Karugire cites a Member of Parliament who expressed concern about the recruitment practices of the Ugandan army as follows:

"...when they (recruiting teams) go to the north, they spend there two or three months recruiting but when they come to Kampala, they spend here one day and they recruit mainly those whom they have directed to come to Kampala because they failed to recruit them in the north. When they go to Masaka, they spend half a day to recruit only about three people - two of them probably being those Northern people who are living in Buganda. When they go to Mbarara, they spend there half a day to recruit only three people. This sort of recruitment must be stopped. They must give us quotas." 256

Compared to armies in the neighboring countries, the Ugandan army at that nascent stage was already peculiar. According to Mamdani (1976) the 1964 army mutinies for higher pay and Africanization in the Kenya, Uganda, and Tanzania encountered different responses.

"In Tanzania, the state power responded by dismissing the leadership and attempting to establish immediate political control over the army by channeling recruits through the TANU Youth League (YTL) and giving each soldier a dose of political education to fill him with ethos of the ruling class. In Kenya, an entire corps of British officers was imported to keep the rank and file in check while a group was rushed off to Sandhurst for training. In Uganda, however, the state power responded to the mutinous soldiers by granting all their demands. Such a response can only be understood in the light of the fact that the army mutiny coincided with a serious split within the ruling petty bourgeois coalition., ${ }^{257}$

Ibingira Grace, a Member of the Uganda Parliament at the time found the Ugandan government reaction to the munity telling. The Parliamentarian revealed that whereas the

\footnotetext{
${ }^{256}$ Ibingira, G. S. K. 1980. African Upheavals Since Independence. Westview Press, p. 84, Cited in Karugire S. R. 1996, Ibid, p. 67.

${ }^{257}$ Mamdani, M. 1976. Ibid, p. 242.
} 
military mutineers in Kenya and Tanzania were held accountable and even expelled from the army, those in Uganda "were publicly dismissed and privately retained because nearly all of them came from Obote's region and their demands were met.. ${ }^{, 258} \mathrm{He}$ asserted that, "Assured of such treatment, discipline steadily went downhill as soldiers felt that they could get anything they wanted however unreasonable."259 It is not surprising therefore that immediately after independence the military took on an increasingly significant role in running the country and in the course of being used by the politicians, it attempted to fashion operational space in the political arena for itself. Karugire put it succinctly when he asserted that that army "increasingly saw that the government was in office largely because of its support. It did not take a great deal of imagination on the part of the army to conclude that instead of propping up quarrelsome politicians who clearly had no support of the populace, it could supplant them." ${ }^{260}$ It is no wonder that postindependence Uganda has been characterized by coups and counter coups for it did not take long for the army to put its stake on state leadership.

\subsection{FROM OBOTE TO AMIN AND BACK TO OBOTE: MILITARISM AND STATE COLLAPSE}

Upon assuming total executive power in 1966, President Obote attempted to rally the country behind him by appealing to different ethnicities while portraying Buganda as a feudal oddity in a country that ought to be unified under one leader - himself. To

\footnotetext{
${ }^{258}$ Karugire, S. R. 1996. Ibid, p. 67.

${ }^{259}$ Ibingira, G. S. K. 1980. African Upheavals Since Independence. Westview Press, p. 84, Cited in Karugire S. R. 1996, Ibid, p. 67.

${ }^{260}$ Karugire, S. R. 1996. Ibid, p. 67.
} 
ingratiate himself with the members of Parliament and the populace, he promulgated another constitution - the 1967 Constitution - and unlike the 1966 constitution, which was inserted in parliamentarian's pigeon boxes, he this time encouraged members of parliament to debate it and even make some amendments. In addition, he tried to fight tribalism and ethnic factionalism by introducing a new method of electing members of Parliament and declared that general elections would be held in 1971. He deprecated the evils of tribal and ethnic divisions thus;

"If the pull of the tribal force is allowed to develop, the unity of the country will be endangered. To reduce it to its crudest from, the pull of the tribal force does not accept Uganda as one country, does not accept the people of Uganda as belonging to one country, does not accept the National Assembly as a national institution but as an Assembly of peace conference delegates and tribal diplomatic and legislative functionaries, and looks at the Government of Uganda as a body of umpires or referees in some curious game of "Tribal Development Monopoly."261

To undercut such tribal forces, he proposed that the contending candidates for parliament instead of contesting for election in one constituency should do so in four constituencies, each in a different region of the country i.e. North, South, East and West. Under this format each candidate's 'home' constituency would be his/her basic constituency and the other three would be his/her national constituency. The assumption here was that such a process would encourage the election of people that are familiar with the problems and

\footnotetext{
${ }^{261}$ Milton Obote Foundation. 1970. Proposals for New Methods of Election of Representatives of the People to Parliament: Document No. 5 on Move to the Left. Kampala, pp.6-7. In Kasfir, N. 1976. The Shrinking Political Arena: Participation and Ethnicity in African Politics, with a Case Study of Uganda. Berkeley: University of California Press, p. 207.
} 
issues affecting different areas of the country, and it could possibly "deter ethnic politics and promote the success of candidates with a national orientation." 262

Ironically, as Obote orchestrated a public anti-tribalism and anti-ethnic factionalism crusade, covertly, he was surrounding himself with his kinsmen, appointing to higher offices only those that kowtowed his policies. This is because in spite of his public rhetoric, he did not gain much popularity in the country. By 1969, his presidency was fraught with assassination attempts which heightened his paranoia and need to be surrounded by people he could 'trust'. His reliance on the military increased even more drastically as it became apparent that both his political career and life were in peril. According to Mamdani (1976), "the importance of the armed forces increased as the ruling bureaucracy, ideologically and organizationally bereft, increasingly relied on the repressive state apparatus."263

Yet, the military was not cohesively behind him and the support he craved began to falter as cleavages within became ever more pronounced. By 1970, he had fallen out of sync with Amin and shifted his trust unto his kinsmen from Lango and Acholi. He relieved Amin of his duties of chief of the army, demoted or reassigned his loyalists to non-strategic positions, and promoted his own kinsmen and trusted officers to sensitive posts. Mamdani offers a similar view when he asserts that "Obote proceeded to manipulate ethnic divisions within the army in order to control it...Acholi and Langi

\footnotetext{
${ }^{262}$ Kasfir, N. 1976. The Shrinking Political Arena: Participation and Ethnicity in African Politics, with a Case Study of Uganda. Berkeley: University of California Press, p. 208.

${ }^{263}$ Mamdani, M. 1976. Ibid, p. 290.
} 
officers were given promotions while other northerners were excluded." ${ }^{264}$ Unfortunately, Obote's ploy did not work as he had hoped it would.

Administratively, President Obote abandoned the meritocracy system and opted for ethnic, regional, and religious concerns in the process of recruitment into and promotion within the civil service. The Public Service Commission, left in place at independence, was rendered useless as the president took it upon himself to appoint, promote, and dismiss civil servants at will. Political interference and strife were the major undoing of the civil service once hailed as the best in Sub-Saharan Africa. In the period 1966-1971, the whole administrative system good standing was eroded. Political calculations spearheaded all administrative actions; members of the UPC were rewarded with promotions without regard to their skills and capabilities; to the rest, morale plummeted as those protected by patronage with impunity started abusing public office and embezzling public funds.

Economically, Obote, attempted to establish a semblance of African Socialism as that in Tanzania under Julius Nyerere and in Ghana under Kwame Nkrumah, by putting in place several programs most notable among them "the Move to the Left" and the "Common Man's Charter." He nationalized the major commercial enterprises and established agricultural cooperatives and other government parastatal organizations, and called for compulsory national service. The policies did not endear him to the Western European countries opposed to any socialist/communistic tendencies rather they further alienated him from both within and without. At this point, conditions both internally and

\footnotetext{
${ }^{264}$ Mamdani, M. 1976. Ibid, p. 291.
} 
externally were ripe for his political leadership to implode and so his policies never saw light of day.

Idi Amin deposed Obote from power on January 25, 1971 while the latter was attending a Commonwealth Conference in Singapore, and a government, more anarchical, brutal, and arbitrary ensued. At first, Ugandans and the international community hailed Amin's assumption of power. He promised to return the country to civilian rule via free and fair general elections and denounced his predecessor's dictatorial tendencies, and sectarian politics. He reached out to the Baganda and even organized the repatriation of the body of the King he helped banish to Britain, visited with the Bishops of both the Catholic and Protestant churches and most notably gave a generous donation to the Catholic church to construct the now famous Uganda Martyrs Shrine at Namugongo. He visited with the Muslim leaders, and even made effort to rehabilitate relations with foreign leaders that Obote had disaffected.

Administratively, he promised to re-establish rule of law, root out corruption, regenerate the civil service, and rekindle public trust in government. To this end, "the appointment of a cabinet of technocrats (there were only two soldiers including Amin in the first military cabinet) who were conversant with the problems of the civil service appeared to mark the beginning of a more competent public administration. ${ }^{265}$ Alas, very few of the promises were honored and before long, he began to shirk expert opinion,

\footnotetext{
${ }^{265}$ Langseth, P. and Justus Mugaju. 1996. Op Cit, p. 9.
} 
abandoned cabinet meetings, "ruled by personal decree and brought about the ossification of political structures. ${ }^{266}$ Heady notes that:

"originally, General Idi Amin adopted a conciliatory stance, engaged in wellpublicized efforts to consult with representatives of divergent groups, encouraged political participation by civilians, retained a largely civilian cabinet, seemed to rely heavily on the professional bureaucracy, and in other ways seemed intent to follow a course of moderation aimed at his own version of a military-intellectual coalition. This indicated partnership between the military and intelligentsia soon dissipated, however, with military dominance becoming more and more evident and being expressed through the personal actions of General Idi Amin.,"267

Under Idi Amin, Uganda became a personal fiefdom of a brutal tyrant, within which there was no semblance of law and order, adherence to established administration, or set policy guidelines. Personal impulses dictated policy, expertise played no role in government and administration, and the economy was reduced to a source of plunder for those in power. As the whole body politic lost all sense of governance, the country spiraled into an abyss of poverty, disease, corruption, theft, looting, murder, and total destruction and collapse. $^{268}$

${ }^{266}$ Decalo, S. 1985. "African Personal Dictatorships.” The Journal of Modern African Studies, Vol. 23, No. 2, p. 225 .

${ }^{267}$ Heady, F. 2001. Public Administration: A Comparative Perspective. New York: Marcel Dekker, Inc., p. 326.

${ }^{268}$ Much has been written about the Amin's regime. See for instance: Patel, H. H. 1972. "General Amin and the Indian exodus from Uganda." A Journal of Opinion, Vol. 2. No. 4, pp12-22; Glentworth, G. and Ian Hancook. 1973. "Obote and Amin: Change and Continuity in Modern Uganda Politics." African Affairs, Vol. 72, No. 288, pp. 237-255; Southall, A. 1975. "General Amin and the Coup: Great Man or Historical Inevitability?" The Journal of Modern African Studies, Vol. 13, No. 1, pp.85-105; Woodward, P. 1978. "Ambiguous Amin." African Affairs, Viol. 77, No. 307, pp. 153-164; Gertzel, C. 1980. "Uganda After Amin: The Continuing Search for Leadership and Control." African Affairs, Vol. 79, No. 317, pp. 461-489; Martin, D. 1974. General Idi Amin. London: Faber and Faber; Mazrui, A. A. 1975. Soldiers and Kinsmen in Uganda: The Making of a Military Ethnocracy. London: Sage Publications; Mamdani, M. 1976. Politics and Class Formation in Uganda. New York: Monthly Review Press; Kasfir, N. 1976. The Shrinking Political Arena: Participation and Ethnicity in African Politics, with a Case Study of Uganda. Berkeley, University of California Press; Gwyn, M. 1977. Idi Amin: death-Light of Africa. Boston: Little, Brown and 
The reign of President Idi Amin (1971-1979), devastated the Uganda civil service. Not only did his reign compound the damage left by the Obote regime, it wrecked more havoc in ways no one could have anticipated. Like his predecessor he totally disregarded the Public Service Commission (PSC) hiring, promoting, and firing workers as he pleased. He went further and placed his administrative trust in the paramilitary groups he established, groups that lacked the skills, technical know-how, and knowledge and zeal to do any public good. The paramilitary groups that Mazrui (1975) called the lumpen militariat and technocrat, ${ }^{269}$ were only military sycophants incapable of grasping complex administrative issues. They simply expected civil servants to carry out their directives without question. Before long, life as a civil servant was intolerable. Those who could afford, fled the country, the ones that could not, abandoned their positions and went back home to till the land, while those that stayed resorted to subservience, scared for their very lives. The civil service became a worthless institution. Decalo (1985) notes that "The writ of the civil service probably did not extend more than 50 miles form the Kampala-Entebbe corridor, except when personally enforced by Amin and especially when accompanied by military force.,"270

The economy was not spared Amin's destruction and this exacerbated the civil service woes. “Amin's expulsion of the Asians was an attempt to win the support of the

Company; Saul, S. J. 1979. The State and Revolution in Eastern Africa. New York: Montly Review Press; Mamdani, M. 1983. Imperialism and Fascism in Uganda. London: Heinmman Educational Books; and Karugire, S. R. 1996. Roots of Instability in Uganda. Kampala, Fountain Publishers.

${ }^{269}$ See Mazrui, A. A. 1975. Soldiers and Kinsmen in Uganda: The Making of a Military Ethnocracy. London: Sage Publications.

${ }^{270}$ Decalo, S. 1985. Ibid, p. 228. 
national bourgeoisie, but the Asians' African successors were inexperienced and the economy declined still further under their management." ${ }^{271}$ Like the majority of the Ugandans, civil servants became economically impoverished. Their salaries, depleted of value, were paid intermittently if at all. Before long, those without state patronage resorted to moonlighting, bribes, theft, and the creation of ghost workers. At this point, the mentality of "everybody for him/herself and God for us all" pervaded the country. Langseth and Mugaju (1996) summarize the effect on Amin's on Uganda's civil service thus:

"For all practical purposes, the civil service ceased to be viable, confident, secure and effective public institution. Performance standards, morale and the integrity system collapsed almost beyond repair. Offices were converted into business premises and points of contact rather than places of official work. Diversion, embezzlement, false claims and outright plunder of public resources were institutionalized. Public resources were used to build private businesses or property (houses and farms). Record keeping and accountability ceased to exist. Many civil servants engaged in conflict of interest activities without any compunction. Moreover, corruption became an open and pervasive integral part of virtually all official transactions.,272

Amin's reign of terror was finally brought to an end on April 11, 1979 by a combined force of Tanzanian soldiers and soldiers of the Uganda National Liberation Front. A rapid succession of short-lived governments followed. Yusuf Lule, a former prominent civil servant in the colonial government, a former Chairman of the PSC, and former Vice Chancellor of Makerere University became president on April 13, 1979 amid great jubilation by the masses. Gertzel (1980) asserts that when Amin was overthrown, the administrative system was in ruins. "Death and exile had depleted the ranks of the

\footnotetext{
${ }^{271}$ Woodward, P. 1978. “Ambiguous Amin. African Affairs, Vol. 77, No. 307, p. 159.

${ }^{272}$ Langseth, P. and Justus Magaju, 1996. Ibid, p. 12.
} 
civil service and the lack of resources had by the end of 1978 ground government almost to a halt, so that at liberation, Uganda was in some respects a country without a bureaucracy." ${ }^{273}$ Unfortunately, the new president, installed by the National Consultative Council (NCC) did not have much time to rectify the situation. Just two months after coming to power the NCC passed a vote of no confidence against him. He fled the country and went to Britain.

President Lule was replaced by Godfrey Binaisa on June 21, 1979 on the recommendation of the NCC. However, on May 11, 1980, the intricate ethnic, religious, and political divisions that characterized the politics of the Obote and Amin regime reared their ugly head. A military commission buttressed by military support staged a coup and dismissed the president and his cabinet ministers, and paved the way for Obote's return. Addressing how the change of leadership from Amin did not generate any fundamental change, Gertzel indicates that: "Within a matter of weeks, the new rulers were submerged in a political debate that produced total paralysis of administration and a struggle for power within their ranks which severely constrained decision-making at the centre....The inability to achieve a new consensus gave greater encouragement to old political divisions.....Their failure was demonstrated by the further intervention of the army in May 1980."274

It should be noted that the military council that deposed Godfrey Binaisa from the presidency was chaired by Obote's long time friend and confidant, Paulo Muwanga. The

\footnotetext{
${ }^{273}$ Gertzel, C. 1980. "Uganda After Amin: The Continuing Search for Leadership and Control." African Affairs, Vol. 79, No. 317, p. 469.

${ }^{274}$ Gertzel. C. 1980. Ibid, p. 462.
} 
latter did not waste time and paved way for Obote's return on May 27, 1980. In December 1980 the now known as controversial elections were held and Milton Obote came back into power. ${ }^{275}$ The controversy was sparked by the general fraudulent way in which they were organized and tallied. Both the Democratic Party (DP) and Uganda People's Movement (UPM) publicly proclaimed that the elections were rigged. Obote II therefore stood no chance of uniting the country or rectifying the ills that had built up through the previous years. Instead, conditions worsened. A guerrila war broke out as Yoweri Musevini leader of the UPM took to the bush. The divisions within the army multiplied. The economy fell apart, the civil service no longer served the public. Obote's government got consumed with self preservation to the detriment of the administrative, economic, and institutional reconstruction badly needed after years of mismanagement. By 1984, Uganda had been reduced the Hobbesian state of nature.

The Oboter II regime was ousted on July 27, 1985 by a military coup organized by his kinsmen from Acholi led by Army Commander Tito Okello Lutwa and Brigadier Barjilio Olara Okello. The two victors did not have time to implement any changes however because Museveni's guerrilla movement which had been gaining ground was now operating in the outskirts of Kampala. A few months later, on January 26, 1986, Yoweri Museveni and his National Resistance Army (NRA) took over the government.

From the above discussion, it is evident that Uganda has since independence suffered what Brett has called 'accelerated regression' with military coup after another. It

\footnotetext{
${ }^{275}$ It is a widely held belief that the elections were rigged in Obote's favor. One of the contestants, Yoweri Museveni, whose party came third in the elections fled to the bush to wage war against the Obote government alleging that the elections were rigged. Obote's second presidency (1981-1985) is commonly referred to as Obote II. I address his second presidency in the same way in this study.
} 
is only since 1986 that the country has managed to experience a coup-less period. Table 5.1 below illustrates the chronology of military coups in post independence Uganda.

Table 5.1 Chronology of Military Coups and Armed take-over in Post-Independence Uganda

\begin{tabular}{|l|l|}
\hline Year Coup/Military Take-over Held & Description \\
\hline 1966 & $\begin{array}{l}\text { Prime Minister Milton Obote backed by the } \\
\text { military suspended the Independence } \\
\text { Constitution, took over the presidency, and } \\
\text { banished the Buganda King and president to } \\
\text { exile }\end{array}$ \\
\hline 1971 & $\begin{array}{l}\text { General Idi Amin overthrew President Obote } \\
\text { while the latter was in Singapore and declared } \\
\text { himself 'Life President' of Uganda }\end{array}$ \\
\hline 1979 & $\begin{array}{l}\text { President Amin was overthrown by a } \\
\text { combined military force from Tanzanian and } \\
\text { the Uganda National Liberation Front }\end{array}$ \\
\hline 1980 & $\begin{array}{l}\text { President Godfrey Binaisa was overthrown by } \\
\text { the Military Council headed by Paulo } \\
\text { Muwanga }\end{array}$ \\
\hline 1985 & $\begin{array}{l}\text { President Obote was overthrown by Army } \\
\text { Commander Tito Okello Lutwa and Brigadier } \\
\text { Barjilio Olara Okello }\end{array}$ \\
\hline 1986 & $\begin{array}{l}\text { Tito Okello Lutwa was despoed by a guerrilla } \\
\text { military force led by Yoweri Museveni }\end{array}$ \\
\hline
\end{tabular}

\subsection{ECONOMIC COLLAPSE IN POST-INDEPENDENCE UGANDA}

The Ugandan economic sector suffered the brunt of the political chaos and mismanagement that prevailed in the country from the 1970s through the 1980s. By the mid-1980s, the Ugandan economy was in a state of critical disequilibrium. Inflation was at an all time high, real Gross Domestic Product (GDP) had declined by $14 \%$ in comparison to the early 1970s. Agriculture, the mainstay of the country and major sector of the economy was weakened by gross distortions in the pricing and marketing systems, and a paucity of inputs, while farmers abandoned their land in war ravaged places. 
According to Tumusiime-Mutebile (1995), the country suffered severe macro economic imbalances as a result of "inflationary financing of successive budget deficits which generated a level of inflation of $161 \%$ in 1986." He asserts further that "an overvalued exchange rate discouraged exports, encouraged imports and reduced foreign exchange reserves."276

It should however be noted that at independence, Uganda's economy was relatively stable in comparison with other newly independent African countries. Even though the country's economy was peasantry and agricultural, and the government sought to implement a dirigisme policy, the economy enjoyed a good export growth and gross domestic savings were stable. Inflation was minimal at -6 at independence, while external debt was almost nonexistent. ${ }^{277}$ Shortly after Idi Amin assumed power on January 25, 1971, the economy suffered a major blow resultant from Amin's expulsion of the Asian business families in 1972. Although it can generally be asserted that the majority of native Ugandans resented the administrative and economic wealth and privilege enjoyed by Ugandan Asians, it cannot be argued that the expulsion redistributed income and wealth. If anything, the economy, especially the formal sector, was put in a precarious position. According to Bigsten and Kayizzi-Mugerwa (2001), "the expulsion put an end to Uganda's post independence prosperity. Investments dried up, exports declined, and

\footnotetext{
${ }^{276}$ Tumusiime-Mutebile, E. 1995. "Management of the Economic Reform Programme.” In Langseth, P., J. Katorobo, E. Brett, and J. Munene. Uganda: Landmarks in Rebuilding a Nation. Kampala, Fountain Publishers, p. 2.

${ }^{277}$ Bigsten, A. and Steve Kayizzi-Mugerwa. 2001. Is Uganda an Emerging Economy? A Report for the OECD Project "Emerging Africa."
} 
per capita incomes fell continuously from 1973."278 Bigsten and Kayizzi-Mugerwa offer three main effects of the Asian expulsion as follows:

- $\quad$ skilled managers were replaced by largely unskilled people, often drawn from the military and with little education

- the appropriation of the Asian properties earned the county a long-lived reputation for lawlessness and property confiscation

- the manner in which former Asian businesses were acquired created insecurity of tenure, leading to asset stripping. ${ }^{279}$

By the time Amin was deposed from power by a combined force of Tanzanian troops and Ugandan renegade army groups, the country's economic performance was a miserable shadow of the one that prevailed between 1962 to1970. GDP, exports, and domestic savings had declined, inflation had skyrocketed, and external debt had expanded. With a steady decrease in GDP, export earnings, and employment, and a high rate of inflation, the government found itself increasingly incapable of providing even the most basic needs. Items like salt, sugar, and soap disappeared from the market, schools lacked basic scholastic materials like chalk, and public hospitals barely operated.

With support from the WB and the IMF, the Obote II regime embarked on some economic reforms to bolster efficiency in the productive sectors, establish monetary controls to ensure frugal spending, and to create a conducive environment for both domestic and foreign investors. According to Bigsten and Kayizzi-Mugerwa (2001),

\footnotetext{
${ }^{278}$ Bigsten, A. and Steve Kayizzi-Mugerwa. 2001. Is Uganda an Emerging Economy? A Report for the OECD Project "Emerging Africa." p. 17.

${ }^{279}$ Bigsten, A. and Steve Kayizzi-Mugerwa. 2001. Ibid
} 
Obote floated the Uganda shilling, increased producer prices for export crops, removed price controls, rationalized tax structures, attempted to reign in government

expenditure. ${ }^{280}$ It should however be noted that these policies only generated measly changes mainly because the political context remained volatile. The Museveni-led guerrilla war took its toll that by 1984 , the government expenditure on the military surpassed all other forms of government expenses and left little or very meager resources for the operation of the other sectors of the government. When the Obote II regime was toppled in 1985 by renegade members of his military, the country was plunged into deeper anarchy. Looting, smuggling, insecurity, scarcity of both consumer and produce goods, and the total breakdown of the government institutional structures, coupled with the rampaging Museveni-led civil war, left the country on the precipice of economic and territorial collapse.

\subsection{FROM THE BRINK: THE NRM AND STATE RECONSTRUCTION IN UGANDA}

When the National Resistance Movement (NRM) took over power in 1986, it found the country traumatized by civil war, state terror and lawlessness, and the public service inefficient, demoralized, unresponsive, and corrupt. In addition, the economy was in disarray, having been thrust into a severe macroeconomic imbalance resultant from severe inflation, budgetary deficits, and a lack of foreign exchange reserves. The NRM government was therefore faced with a myriad of issues that needed immediate attention

\footnotetext{
${ }^{280}$ Bigsten, A. and Steve Kayizzi-Mugerwa. 2001. Is Uganda an Emerging Economy? A Report for the OECD Project "Emerging Africa." p. 19.
} 
before the country could be ably placed on the path to recovery and reconstruction. One of the contextual imperatives was the establishment of law and order. Before any fundamental reforms could be pursued, the government had to restore law and order and gain total control of the entire country so that political stability can be ensured. Establishing law and order proved a colossal task to accomplish because armed factions of the previous government were still at large and new rebellions were forming in the northern and eastern parts of the country. According to Langseth and Mugaju (1996), from 1987 to 1991 government concentrated its energies and resources on containing and defeating rebellions rather than embarking on post-war recovery and reconstruction. ${ }^{281}$ Another major contextual imperative that took precedence was stabilization of the economy. When he assumed political power, President Yoweri Museveni and his NRM government, faced with severe economic and fiscal problems and virtually no internal institutional capacity to address them, sought the intervention of multilateral organizations like the WB and the IMF to help in the design, funding, and implementation of an economic recovery program. The program began effectively in 1987 with the following objectives:

- to stabilize the economy

- to achieve economic growth of $5 \%$ per annum

- to reduce inflation to stable levels, and

- to achieve a viable balance of payments position and a sustainable financing of deficits.

\footnotetext{
${ }^{281}$ Langseth, P. and Justus Mugaju. 1996. Ibid, p. 18.
} 
The above objectives were to be achieved via a comprehensive economic reform program enshrined in what is commonly known as the Structural Adjustment Programs (SAPs). According to Van de Walle (2001), many African countries have with the assistance of international financial institutions notably the WB and IMF "attempted to implement stabilization and structural adjustment programs that seek to return to macroeconomic equilibrium in the short term and promote more rapid sustainable economic growth in the long term. ${ }^{282}$ Indeed, the late 1980s through the 1990s witnessed economic, institutional, political, and administrative changes in government functioning aimed at improving the socio-economic conditions of the people of Uganda.

The basic ingredients of the SAPs adapted in Uganda included among others: currency devaluation, raising interest rates to fight inflation, cuts in government spending, privatization of government enterprises, civil service reform, deregulation of prices of goods and services, and export promotion. Most of these programs involved a contraction in the scope of administration. They entailed the withdrawal of government from certain functions, reduction of the parastatal sector, and the delegation of power and responsibilities to the lower level administrative organs, local government, and to the private sector. A quest for financial viability called for more control in spending, improved budgeting, and enforcing accountability.

Notable changes have occurred under the NRM government (1986 to date) because it embraced the structural adjustment programs. However, it should be noted that positive change was not spontaneous. Indeed, inflation continued to soar in the first few

\footnotetext{
${ }^{282}$ Van de Walle, N. 2001. African Economies and the Politics of Permanent Crisis, 1979-1999. Cambridge, Cambridge University Press, p. 7.
} 
years of NRM rule that by the 1988 financial year, it peaked at 200 percent. In addition, the government external debt continued to grow and to date, it remains a very big hindrance to economic growth as debt servicing diverts the much needed resources from social sectors like education and health. In spite of these drawbacks, the ERP generated some key positive changes. For instance, the GDP growth was by the end of 1987 revitalized and it has since continued to grow. According to Tumusiime-Mutebile, the economic recovery program has been quite impressive. He asserts that "the objective of $5 \%$ real economic growth was exceeded in each year from 1987 to $1994, \ldots$ reflecting not only a recovery in agricultural production, but also strong growth in other sectors like manufacturing and infrastructure." He asserts further that "average growth in GDP for the years 1986 to 1994 was about 5.6\%." In his view, "prudent fiscal policy, avoiding recourse to inflationary financing of budget deficits, and prioritizing expenditure needs within accepted resource constraints has meant efforts to achieve price stability have largely been successful., ${ }^{283}$ Indeed by the 1990s, the economy had become relatively stable, inflation had been reduced and budget deficits were being dealt with in more economically appropriate ways and basic goods like sugar, soap, and salt were readily available, inflation had gone down, real economic growth was on the rise, and the market system had become operationally steady.

\footnotetext{
${ }^{283}$ Tumusiime-Mutebile, E. 1995. “Management of the Economic Reform Programme.” In Langseth, P., J. Katorobo, E. Brett, and J. Munene. Uganda: Landmarks in Rebuilding a Nation. Kampala, Fountain Publishers, p. 3.
} 
However, like many developing countries, Uganda has had to face the challenge of what Kautsy (1972) calls "modernization from without."284 Hence, although the structural adjustment programs aimed at paving the way for socio-economic change and reinvigoration, they were largely viewed with skepticism and reservation. TumusiimeMutebile, the Ugandan Permanent Secretary and Secretary to the Treasury, Ministry of Finance, for the first fifteen years of NRM rule, also acknowledged that the major reform efforts were driven by the requirements of conditionality and that the Ugandan government was quite defensive towards the IMF and WB conditionalities. ${ }^{285}$ Yet, because economic reform in Uganda was a necessity and the only viable way to raise the country from the doldrums of its miserable past, the conditionalities did not seem to be critical impediments. In fact, Uganda embraced the reforms and their conditionalities whole heartedly. As a result, Uganda has been hailed as model of the SAPs compliance and many critics are pleased with success of economic recovery reforms. ${ }^{286}$

The political and institutional contexts were also critical areas that needed to be streamlined so that structural and political weaknesses are removed before the government could embark on full-scale reform programs. As a result, government established a broad-based system of governance in which public participation was

\footnotetext{
${ }^{284}$ Kautsky, J. H. 1972. The Political Consequences of Modernization. New York: John Wiley and Sons, Inc. pp. 44-45.

${ }^{285}$ See Tumusiime-Mutebile, E. 1995. "Management of the Economic Reform Programme.” In Langseth, P., J. Katorobo, E. Brett, and J. Munene. Uganda: Landmarks in Rebuilding a Nation. Kampala, Fountain Publishers, p. 3.

${ }^{286}$ See Tripp, A. M. 2000. Women and Politics in Uganda. Madison: University of Wisconsin Press; Bigsten, A. and Kayizzi-Mugerwa, S. 2001. Is Uganda an Emerging Economy? Uppsala: Nordiska Afrikainstitutet; Hansen, B. H. and Michael Twaddle, eds. 1998. Developing Uganda. Oxford, James Currey; Van de Walle, N. 2001. African Economies and the Politics of Permanent Crisis, 1979-1999. Cambridge: Cambridge University Press.
} 
crucial. Public participation was practiced through the policy of decentralization and through Resistance Councils and Committees (RCs) ${ }^{287}$ to which the powers that come with devolutionary decentralization were given.

The Resistance Council (RC) system is a hierarchical structure of councils and committees that starts at the Village level (RC1), to the Parish level (RC2), the Subcounty level (RC3), the County level (RC4), and the District level (RC5). According to Tukahebwa (1998), "this kind of local government structure presents a break with the past in that it significantly undermined the hitherto authoritarian tendencies of the chiefs."288 The NRM passed the Resistance Council Committees Statute No.9 in 1987 which effectively conferred administrative powers and responsibilities on local communities while the legal framework for decentralization was provided by the Local Government and RCs Statute of 1993. To further enhance the political stability of the country and establish democratic norms, the government embarked on constitutional reforms that culminated in the enactment of the 1995 Uganda Constitution.

\subsection{THE CIVIL SERVICE REFORM PROGRAM IN UGANDA}

In 1989, the NRM government with the financial support of the United Nations Development Program (UNDP) set up the Public Service Review and Reorganization Commission (PSRRC) by Legal Notice No.2 of 1989, to examine the civil service

\footnotetext{
${ }^{287}$ It should be noted that with the ratification of the 1995 Uganda Constitution, RCs were turned into Local Councils (LCs).

${ }^{288}$ Tukahebwa, G. 1998. "Political and Administrative Relations in Decentralization.” In Nsibambi A. (Ed.) Decentralization and Civil Society in Uganda: The Quest for Good Governance. Kampala: Fountain Publishers, p.15.
} 
problems and make appropriate recommendations. According to Langseth and Mugaju, the main task of the PSRRC was to "carry out a comprehensive reform of the public service; to pinpoint its structural weaknesses; to identify the causes of its poor performance; and to recommend ways of restructuring and reorganizing the institution to make it cost effective, efficient, and responsive in the management of public affairs."289 Specifically, the Commission was to focus on four major issues namely; personnel management issues, organization structure, accountability/financial management, and conditions of service. ${ }^{290}$

The Commission found that the Uganda Public Service was bloated in structure, inefficient, and generally a poor performer. It identified the following as major issues afflicting the civil service system: a) inadequate pay and benefits b) poor management skills c) dysfunctional civil service organization d) inadequate personnel management and training. In the Commission's view, the latter led to abuse of office and government property, moonlighting and corruption, lack of discipline, an erosion of rules and regulations, obsolete procedures, lack of appropriate systems, thin managerial and technical skills, poor public attitudes, and massive bureaucratic red tape.

The PSRRC made numerous recommendations ${ }^{291}$ on how to revamp the Service namely: 1) Rationalization of Government Structures and Functions including

\footnotetext{
${ }^{289}$ Langseth, P. and Justus Mugaju. 1996. Ibid, p.19.

${ }^{290}$ Government of Uganda, Ministry of Public Service. 1994. Management of Change: Content, Vision, Objectives, strategy and Plan. Kampala: Uganda Printing and Publishing Corporation, p. 3.

${ }^{291}$ A total of 255 recommendations were made, but for strategic reasons and the need to prioritize and focus on the most critical areas, government focused on the above seven components. See appendix 2 for the entire list of the recommendations.
} 
Decentralization of power to districts; 2) Reduction of the size of the Public Service; 3)

Pay Reform through salary enhancement and monetization of non-cash benefits; 4)

Personnel and Establishment control; 5) Improvement of Records Management; 6)

Introduction of Results Oriented Management; and 7) Capacity Building. ${ }^{292}$ These recommendations which were accepted by Government and endorsed by the National Resistance Council (NRC) $)^{293}$ in Sessional Paper No. 1 of 1991 formed the basis of the Civil Service Reform Program (CSRP). The overall objective of the program was to create a service that is small, motivated, accountable, efficient, effective, productive, and responsive. According to the ministry of Public Service, the above objectives were to be realized through a number of measures that include the following:

- Clear demarcation of the respective roles and responsibilities in general and functional allocations, and lines of authority between central ministries and field staff working under local authorities

- Revitalization of decentralized selection, promotion, and disciplining of professional staff

- Management by results operational system incorporating success indicators which allow performance to be judged and appropriately rewarded/sanctioned

\footnotetext{
${ }^{292}$ The Public Service Review and Reorganization Report, 1989, Kampala: Uganda Printing and Publishing Corporation.

${ }^{293}$ The national Resistance Council (NRC) was the legislative body (equivalent to the Parliament) of government from 1987-1996. It was abandoned after the ratification of the 1995 Constitution and in 1996, new parliamentary representatives were elected into office
} 
- A salary and incentive system which provides a 'living wage' on the basis of appropriate levels of staffing and comparability with similar tasks in the private sector, and which contains strong performance-based incentives

- A systematic capacity and skills development process which relates training to function at all levels of the civil service. ${ }^{294}$

Although the above discussion indicates that initiative for civil service reform was the brainchild of the NRM government, external influence cannot be under estimated. Indeed, external initiatives for reform were paramount in providing both the technical and financial resources for both the reform program formulation and implementation. Donor influence in Uganda has arguably been at its highest during the NRM regime. The IMF and WB have notably been at the forefront of pushing the government to reform. The government embraced the SAPs as a conditionality for aid. In exchange for financial support, the NRM government agreed to establish recommended reforms like market liberalization, deregulation, privatization, civil service reform, constitutional reform, and judicial reform among others. As shall be illustrated in the pages ahead, donor funding has been instrumental in facilitating the different aspects of the civil service reform program in Uganda.

The civil service reform program in Uganda therefore has not been implemented in isolation. There have been numerous economic, institutional, and political reforms implemented since the NRM assumed power in 1986. In fact, there is a strong linkage

\footnotetext{
${ }^{294}$ Government of Uganda, Ministry of Public Service. 1994. Management of Change: Content, Vision, Objectives, strategy and Plan. Kampala: Uganda Printing and Publishing Corporation, p. 24.
} 
between the various reform efforts and their success depends on effective coordination. Although it took the government three years into power to turn its change efforts to civil service reform, it was mindful of the fact that the revamping and reorganization of the civil service is paramount for long term post-war reconstruction and general revitalization of the economic, political, and institutional capabilities of the country. In Figure 5.1 below I illustrate the contextual framework of the reform programs undertaken by the NRM regime soon after attaining political power. It should be noted that these reforms work together and their synergy is critical in engendering the administrative, economic, and political transformation of the country.

Figure 5.1 A contextual Framework of the Reforms undertaken by the NRM in the early 1990s

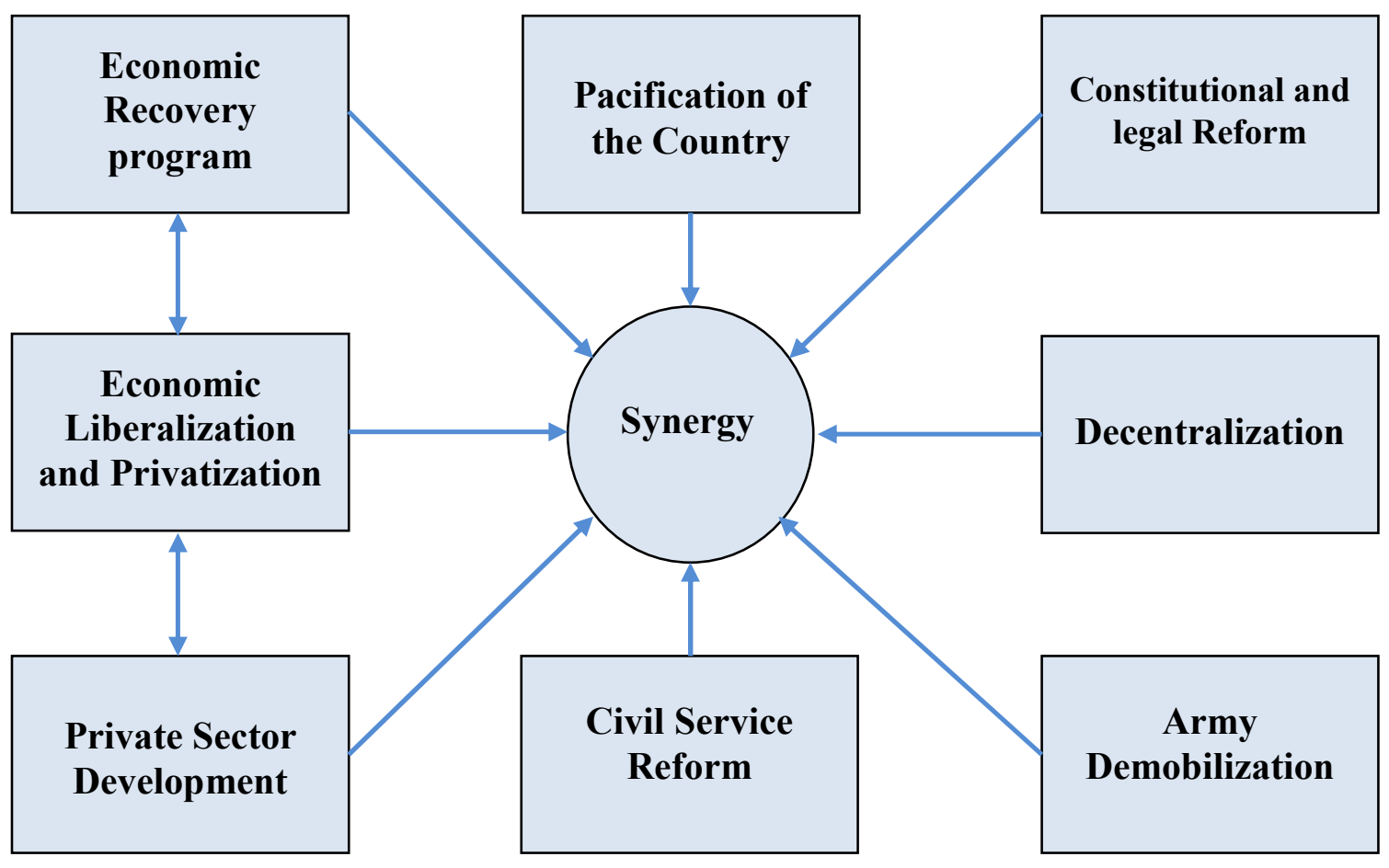




\subsection{SUMMARY}

The discussion above has addressed the political and economic chaos that plagued Uganda soon after independence through the 1970s, 1980s and much of the 1990s. Throughout that period, the country was characterized by immense political turmoil and economic collapse that negatively affected the performance, service delivery, management, and financial viability of the civil service. Idi Amin's military dictatorship coupled with Milton Obote's subsequent authoritarian rule destroyed all mechanisms of administrative, political, and financial accountability, thereby eliminating effective management, monitoring, and control within the civil service. It has been shown that it is only under the NRM government that more serious reform programs have been undertaken among them structural adjustment programs comprising administrative reforms, economic reforms, and political reforms in an attempt to rectify the situation. The Uganda civil service found in a state of disrepair was viewed as a problem rather than a solution to the country's socio-economic and political collapse hence effort was made to build it into a better and more professional service. Chapter six is focused on that effort.

\subsection{ECONOMIC STAGNATION IN TANZANIA}

\subsubsection{Introduction}

In contrast to post-independence Uganda which has experienced great political strife, post-independence Tanzania has overall enjoyed political stability. According to Kithingi Kiragu (1999), the country is considered to be one of the most stable nations in 
Africa. ${ }^{295}$ Tanzania's stability is largely credited to the country's first president, Julius K. Nyerere, who encouraged and nurtured ethnic cohesion, a homogeneous language, and smooth political leadership transitions. However, to say Tanzania is Africa's peace nest would be to stretch the reality. Tension between the mainland and the Zanzibar islands has been building and the last few elections have seen it escalate to near chaos. Most important though, the country has suffered one of the most biting economic stagnation resulting from the socialist economic ideology and policies enshrined in what is commonly known as "African Socialism".

The remainder of this chapter provides a historical look at the political-economic developments in post-independence Tanzania. Focus is placed on the factors that led to economic stagnation namely; Ujamaa socialism, villagization, and the quest for selfreliance. A discussion of how the ensuing crisis affected the civil service is offered. The discussion shows that the CSRP is part of the wider SAPs reform efforts that were undertaken to revamp the dire economic state of affairs in Tanzania.

\subsection{FROM COLONIALISM TO UJAMAA AFRICAN SOCIALISM}

Tanzania attained independence on December $9,1961^{296}$ under the umbrella of a popular political party, the Tanganyika African National Union (TANU). It championed the interests of the masses in the rural areas, the intellectuals and the city dwellers, and

\footnotetext{
${ }^{295}$ Kiragu, K. 1999. "Tanzania" in Public Administration in Africa: Main Issues and Selected Country studies. Ladipo Adamolekun ed. Boulder, Co: Westview Press.

296 At independence, the country was known as Tanganyika. It was renamed the Republic of Tanzania in 1962 after uniting with the Island of Zanzibar.
} 
Muslims and Christians alike. Unlike Uganda and most other African countries, Tanzania did not experience post-independence leadership conflicts between personalities, religions, or tribes. This unique scenario can be explained by a number of factors. Historically dating as far back as the pre-colonial period, the country had various small scattered tribal units without overriding power centers that could have vied for national dominance. Further, a common language Swahili, helped to unite the populace by bridging the gap between the political leadership, the educated and urban dwellers, and the masses. Another notable factor is the strong and dynamic post-independence leadership. The country's first President, Julius Nyerere, who was also TANU's first chairman, is known as the father of the nation precisely because he was able to fashion and maintain a united nationhood.

The attainment of independence did not usher in a complete detachment from colonial tenets however. British administrative and economic institutions and structures remained in place. The Africanization program ensured more African representation in government and the civil service, but bureaucratic structures and norms did not alter much. Even the political institutions like the cabinet and legislature were molded against those in Britain. Whereas the colonial political and administrative systems were more or less maintained, the new leadership found it hard to espouse the colonial economic ideals. This is because the colonial economic set up created small pockets of growth in a few towns and areas that were endowed with fertile soils, and left the rest of the country underdeveloped. Moreover, the fruits of economic growth were reaped by the colonialists and other foreigners like Indians while the majority of the natives languished in poverty and scarcity. Social services like education, health centers, roads, and processing plants 
were confined to the productive parts of the country. President Nyerere therefore was adamant that inequality and class formation be cut in the bud. Yet, during the immediate post-independence period 1961-1966, the economy remained steady with per capita income growing by $2 \%$ per year. ${ }^{297}$ Table 5.2 depicts trends in select economic indicators for the period 1961 to 1967.

Table 5.2 Data for the Pre-Arusha Declaration Period 1961-1967

\begin{tabular}{|l|c|c|c|c|c|c|c|}
\hline & $\mathbf{1 9 6 1}$ & $\mathbf{1 9 6 2}$ & $\mathbf{1 9 6 3}$ & $\mathbf{1 9 6 4}$ & $\mathbf{1 9 6 5}$ & $\mathbf{1 9 6 6}$ & $\mathbf{1 9 6 7}$ \\
\hline $\begin{array}{l}\text { Per Capita } \\
\text { Income Growth (\%) }\end{array}$ & -7.1 & 4.3 & 1.2 & 3.6 & -0.2 & 9.9 & 1.8 \\
\hline $\begin{array}{l}\text { Population } \\
\text { Growth (\%) }\end{array}$ & 2.8 & 2.8 & 2.9 & 2.9 & 2.9 & 3.0 & 3.0 \\
\hline Urbanization (\%) & 0.8 & 4.9 & 5.1 & 5.2 & 5.3 & 5.6 & 5.9 \\
\hline Terms of Trade & 130 & 124 & 137 & 142 & 137 & 137 & 126 \\
\hline $\begin{array}{l}\text { \% of Labor Force } \\
\text { in Agriculture }\end{array}$ & 92.4 & 92.1 & 91.9 & 91.7 & 91.4 & 91.2 & 90.9 \\
\hline Monetary Growth (\%) & - & 21.7 & 25.6 & -15.2 & 31.8 & 476.7 & 13.1 \\
\hline Inflation (\%) & 7.8 & 0.6 & 4.9 & 2.8 & -2.4 & 9.3 & 11.5 \\
\hline $\begin{array}{l}\text { Gross Investment } \\
\text { \% of GDP }\end{array}$ & 13.7 & 11.6 & 10.7 & 12.0 & 13.9 & 15.1 & 18.9 \\
\hline
\end{tabular}

Source: Bigsten, A. and Andres Danielson. 2001. Tanzania: Is the Ugly Duckling Finally Growing Up? A Report for the OECD Project "Emerging Africa, p. 15.

Table 5.2 shows that after independence, the country was characterized by economic stability. Inflation was generally low and investment was steadily on the increase. The table also shows that the majority of the workers found employment in the agricultural sector. It should be noted that not long after, the entire country would come to depend on the agricultural sector for economic development. Nonetheless, it was argued that the

\footnotetext{
${ }^{297}$ Bigsten, A. and Andres Danielson. 2001. Tanzania: Is the Ugly Duckling Finally Growing Up? A Report for the OECD Project "Emerging Africa." The authors assert that that is the highest rate of any period in the post-independence period.
} 
Tanzanian economy "developed as an off-shot of the economy of the colonial power,"298 which made it depend on the unpredictable international capitalist markets. Moreover, although the economy was developing steadily and Africanization was filling government positions with natives, it was perceived that the benefits accrued to only a privileged few, among them; political leaders, senior civil servants, and those in the commercial sector. It did not take long therefore, for the new leadership to draft fresh economic and social development programs.

The country's new economic development program was ushered in by President Nyerere when he released the Arusha Declaration National Development Policy Statement in February 1967. The policy aimed at making the country socialist and selfreliant, through the development of an economy based on local agricultural production. It was envisaged that an indigenous economy would generate structural changes, promote equity, and accelerate rural development. The Declaration asserted that the country was to commit itself to build socialism based on African values. In Nyerere's view, socialism meant Ujamaa - Swahili for familyhood - that is rooted in communal involvement of family members. He emphasized that this economic philosophy meant that all economic endeavors would be based on the traditional patterns of the African society in which the common good was valued higher than individual gain. He asserted that:

"The foundation, and the objective, of African Socialism is the extended family. The true African socialist does not look on one class of men as his brethren and another as his natural enemies....'Ujamaa,' then, or 'familyhood,' describes our Socialism. It is opposed to Capitalism, which seeks to build a happy society on the basis of the exploitation of man by man; and it is equally opposed to the

\footnotetext{
${ }^{298}$ Cliffe, L. 1969. "From Independence to Self-Reliance.” In Kimambo, I. N. and A. J. Temu (eds) $A$ History of Tanzania. Nairobi: East African Publishing House, p. 241.
} 
doctrinaire socialism which seeks to build its happy society on a philosophy of inevitable conflict between man and man."299

His socialist society was to be comprised of workers who would control the tools of production and mechanisms of exchange, and where each able member would contribute to the total wealth and welfare of the society, and benefit in proportion to his/her contribution. He viewed this society as drastically different from an aristocratic one that valued social class based on birth or the capitalist one in which individual wealth and competitiveness are glorified. He asserted that the virtues of the socialist society are unique because:

"First, both the organization and the teaching will emphasize man's cooperative spirit - his desire to work in harmony with his friends and neighbors - not his personal aggressiveness. Second, it will reserve its highest respect and its highest prizes for those whose life and work demonstrate the greatest service, not the greatest personal acquisitiveness....Success in a socialist society will imply that a man has earned the respect, admiration, and love of his fellow citizens, by his desire to serve, and by the contribution he has made to the well-being of the community.",300

His goal was to have the people mobilized into Ujamaa villages in which they would together cultivate communal land and share the produce together as a community. It should be noted that traditional communities lived in scattered family groups on small land holdings often in a nomadic manner as they searched for fertile land and water. Such settlement pattern made provision of services difficult and expensive. In Nyerere's view, if people were encouraged to live in proper village communities, access to services would

\footnotetext{
${ }^{299}$ Nyerere, K. J. 1964. "Ujamaa: The Basis of African Socialism.” In Friedland, W. H. and Carl G. Rosberg, Jr. (eds). African Socialism. Stanford, CA: Stanford University Press, p. 246.

${ }^{300}$ Nyerere, K. J. 1968. Uhuru na Ujamaa: Freedom and Socialism. Oxford University Press. In McDonald, D. A. and Eunice N. Sahle (eds). The Legacies of Julius Nyerere: Influences on Development Discourse and Practice in Africa. Trenton, NJ: Africa World Press, p. 119.
} 
be improved and development would be attained. Communal settlements therefore were perceived to be the avenues through which service provision and new agricultural extension services would be availed to the peasant farmers.

Embedded in Nyerere's philosophy were self-reliance and egalitarianism. He wanted the people to not wait for what the government could do for them, but to focus on what they could do for it and for one another. Self-reliance would be generated by the combined efforts of the people, proper utilization of land, implementation of good policies, and presence of good leadership to provide proper guidance. To this end, the contribution from government and other organizations to the development of Ujamaa villages would be confined to the following: education to explain as widely as possible the underlying principles of Ujamaa villages; promotion of good leadership among the farmers and commitment among government leaders and officials; and adequate planning. ${ }^{301}$

Local initiative and drive were considered paramount while official government leadership and bureaucratic involvement were supposed to be minimal so as to "avoid the danger of bureaucratic control, coercion and over-capitalization, which would negate the very principles of self-help and voluntary cooperation which the villages are intended to embody. ${ }^{302}$ Nonetheless, a Rural Development Fund (RDF) managed by the regional authorities was put in place to promote village development. It has been argued that contrary to prescription, the bureaucracy was coercive in its educational and politicization

\footnotetext{
${ }^{301}$ United Republic of Tanzania. 1969. Tanzania Second Five-Year Plan for Economic and Social Development, 1969-1974. Dar es Salaam: Government Printer, p. 28.

${ }^{302}$ United Republic of Tanzania. 1969. Ibid, p. 4.
} 
programs, and in urging people to move to new villages. By 1974, the aggressiveness had paid off for it was estimated that there were 5,000 villages with two and half million members (approximately $18 \%$ of the national population). ${ }^{303}$

In order to advance egalitarianism, President Nyerere promoted income distribution through the reduction of the salaries of the civil servants and politicians, including his, and directed that no government worker could own a private business or employ another person. In addition, free social services including health care and primary education were offered. He focused attention on rural development by channeling large amounts of the government resources to rural farming and agriculture. The education system too was changed to advance the ideals of socialism. The colonial curriculum was modified to give more courses in agricultural development, cooperation, self-reliance, and other areas that would advance socialism; and prepare the school leavers to build an appropriate existence for themselves and their communities in the rural area.

Self-reliance was supposed to induce a gradual detachment from the hold of the international capital markets. Therefore, a lot of resources were injected into developing the country's local industries. National Cooperatives were formed in nearly all sectors of the economy, while key industries in manufacturing, commerce, construction, and banking came under government control. It was believed that these measures would engender fast development without heavy reliance on external support.

For some time, Ujamaa socialism seemed to thrive. Agricultural production increased, health care and sanitation facilities multiplied even in the remotest villages,

\footnotetext{
${ }^{303}$ Lofchie, M. F. 1978. "Agrarian Crisis and Economic Liberalization in Tanzania.” The Journal of Modern African Studies, Vol. 16, No. 3, pp. 451-475.
} 
and school enrollment and adult education increased. It has been asserted that the most significant achievement of Ujamaa was increase in the country's literacy rate. Amani et al. (2006), note that the rate was $33 \%$ in 1970 and by 1980 it had risen to approximately $90 \% .{ }^{304}$ Further, as the country embraced the import substitution strategy, state patronage expanded investment and manufacturing. Not surprisingly, the scope and size of the government expanded rapidly. It has been asserted that parastatals increased from 43 in 1966 to 380 in 1979 , and by 1980 they were $425 .{ }^{305}$ Table 5.3 shows the economic performance during the first ten Ujamaa years.

\section{Table 5.3 Data for the Pre-Crisis Period 1968-1978}

\begin{tabular}{|l|c|c|c|c|c|c|c|c|c|c|c|}
\hline & $\mathbf{1 9 6 8}$ & $\mathbf{1 9 6 9}$ & $\mathbf{1 9 7 0}$ & $\mathbf{1 9 7 1}$ & $\mathbf{1 9 7 2}$ & $\mathbf{1 9 7 3}$ & $\mathbf{1 9 7 4}$ & $\mathbf{1 9 7 5}$ & $\mathbf{1 9 7 6}$ & $\mathbf{1 9 7 7}$ & $\mathbf{1 9 7 8}$ \\
\hline $\begin{array}{l}\text { Per Capita } \\
\text { Income Growth (\%) }\end{array}$ & 2.1 & -0.7 & 3.0 & 0.8 & 2.3 & 0.5 & -0.5 & 2.9 & 2.3 & -2.7 & -1.9 \\
\hline $\begin{array}{l}\text { Population } \\
\text { Growth (\%) }\end{array}$ & 3.0 & 3.0 & 3.0 & 3.0 & 3.0 & 3.0 & 3.0 & 3.0 & 3.1 & 3.1 & 3.1 \\
\hline Urbanization (\%) & 6.1 & 6.4 & 6.7 & 7.4 & 8.1 & 8.7 & 9.4 & 10.1 & 11.0 & 12.0 & 12.9 \\
\hline Terms of Trade & 126 & 126 & 137 & 123 & 128 & 146 & 174 & 142 & 152 & 182 & 152 \\
\hline $\begin{array}{l}\text { \% of Labor Force } \\
\text { in Agriculture }\end{array}$ & 90.6 & 90.3 & 90.1 & 89.7 & 89.3 & 88.5 & 88.1 & 87.7 & 87.2 & 87.2 & 86.7 \\
\hline $\begin{array}{l}\text { Monetary } \\
\text { Growth (\%) }\end{array}$ & 17.8 & 9.2 & 12.0 & 18.2 & 17.7 & 18.2 & 22.1 & 24.4 & 25.1 & 20.2 & 12.3 \\
\hline Inflation (\%) & 14.5 & 15.2 & 3.5 & 4.7 & 7.4 & 9.9 & 17.9 & 23.2 & 6.6 & 11.0 & 6.4 \\
\hline $\begin{array}{l}\text { Gross Investment } \\
\text { \% of GDP }\end{array}$ & 18.4 & 16.3 & 22.9 & 26.8 & 23.6 & 22.6 & 21.3 & 20.8 & 29.0 & 29.4 & 33.8 \\
\hline
\end{tabular}

Source: Bigsten, A. and Andres Danielson. 2001. Tanzania: Is the Ugly Duckling Finally Growing Up? A Report for the OECD Project "Emerging Africa", p. 16.

\footnotetext{
${ }^{304}$ Amani, H. K. R. et al 2006. "Understanding Economic and Political Reforms in Tanzania." In Mensah, J. (ed.) Understanding Economic Reforms in Africa. New York: Palgrave Macmillan.

${ }^{305}$ Bagachwa, M. S. D. and Limbu, F. 2006. In Amani, H. K. R. et al 2006. "Understanding Economic and Political Reforms in Tanzania." In Mensah, J. (ed.) Understanding Economic Reforms in Africa. New York: Palgrave Macmillan.
} 
Table 5.3 shows that not all aspects of the economy flourished. Per capita income declined and external debt started to accumulate. The rise in external debt is attributed to the high level of donor support for investment programs. Although the country's socialist policies were viewed with skepticism and some contempt by some western capitalist countries, a good number of them were intrigued and impressed by the Tanzania's boldness and motivation. The country's innovative programs through which it sought to provide social services and foster self-reliance and egalitarianism, excited some donors. Aid flowed from the USA, Canada, West Germany, and the UK among others; and from socialist countries namely China, the Scandinavian countries, and Russia. Indeed, the country's total aid per capita rose from 2.7 billion dollars in 1970 to 30.6 billion dollars in $1978 .^{306}$

In spite of the international support and domestic political enthusiasm however, by 1975 , gains from Ujamaa socialism had started to dwindle. It has been asserted that the "road to economic disaster in Tanzania had been paved with the best of intentions: the goal there was a conflict-free commonwealth of peasant villages working communally with their leaders, a long way from exploitation, big cities, and impersonal industrial modernism. ${ }^{, 307}$ What was attained however is far different from the goal. The peasant did not work communally among themselves and with their leaders, agricultural productivity plummeted, scarcity ensued, inflation rose, and the general economy stagnated. The next

\footnotetext{
${ }^{306}$ Bigsten, A. et al. 1999. Aid and Reform in Tanzania. Washington, D.C: The World Bank.

${ }^{307}$ Chege, M. 1994. "Swapping Development Strategies: Kenya and Tanzania After their Founding Presidents." In Political Development and the New Realism in Sub-Saharan Africa. Apter, D. E. and Carl, G. Rosberg (eds.) Charlottesville: University Press of Virginia, p. 266.
} 
section addresses the consequences of Ujamaa socialism on the Tanzanian economy and the effect on the administrative system.

\subsection{AFRICAN SOCIALISM UNREALIZED: THE TANZANIAN ECONOMIC CRISIS 1975 - 1985}

It has been argued that a number of factors undermined the functioning of Ujamaa socialism in Tanzania. ${ }^{308}$ Among them are faulty government policies and programs, vagaries of nature and an unstable international market system, and the Uganda war.

\section{Faulty Government Policies and Programs:}

The Ujamaa socialist economic policy was inherently faulty. At its core was the assumption that people would willingly embrace the villages and undertake farm work in communal harmony. In reality, voluntary formation of villages was sluggish and the government realized that incentives would have to be used to attract people into the communes. For instance, certain taxes were levied against those that did not move into the villages, those that moved were offered some land rights, and even social services like clean water, famine aid, and medical services were selectively offered to those in Ujamaa villages. However, resistance persisted and before long, three forms of communal villages emerged. According to Coulson (1982), the first form was composed of villages

\footnotetext{
${ }^{308}$ Numerous scholars have articulated reasons why Ujamaa failed to deliver its promises. See for instance Ergas, Z. 1980. "Why did the Ujamaa Village Policy Fail? Towards a Global Analysis." The Journal of Modern African Studies, Vol. 18, No. 3, pp. 387-410; Lofchie, M. F. 1978. "Agrarian Crisis and Economic Liberalisation in Tanzania." The Journal of Modern African Studies, Vol. 16, No. 3, pp. 451-475; Cline, W. R. and Sidney Weintraub (eds) 1981. Economic Stabilization in Developing Countries. Washington, D.C: The Brookings Institution; Coulson, A. 1982. Tanzana: A Political Economy. London: Clarendon Press; Hyden, G. 1983. No Shortcuts to Progress: African Development in Management Perspective. Berkeley: University of California Press; Maliyamkono, T. L. and Bagachwa, M. S. D. 1990. The Second Economy in Tanzania. London: James Currey; and Bukuku, E. S. 1993. The Tanzanian Economy: Income Distribution and Economic Growth. Westport, CONN: Praeger.
} 
that were formulated before the Arusha Declaration. They were small, politically aware, and dedicated to communal work. The second form was comprised of villages that emerged in order to enjoy government benefits like subsidies and fertilizers but that were not driven by the desire for communal work. The third type was composed of larger villages that were forcibly formed by government. ${ }^{309}$ Other than the first group, the other groups were not interested in communal farming. The incentive to do so was to gain access to amenities like schools, clinics, and sanitation services, but when it came to farming, no one wanted the government to take control of their harvest. In essence, communal farming never took hold and agricultural production never did significantly increase.

Between 1971 and 1972, agricultural production reduced because peasants neglected the call to communal farming. Moreover, during the same period, producer prices plummeted causing a fall in export earnings. By 1973, it became increasingly clear that not all farmers were interested in Ujamaa. Those in dry and famine-prone areas were keen to move into communal villages but those in fertile areas were not. The latter were more interested in private agricultural production. In the last quarter of 1973, the TANU leadership and President Nyerere announced mandatory villagization and made it clear that living in communal villages was no longer a voluntary undertaking. However, the call did not entail Ujamaa - communal farming. Rather, peasants would be availed blocks of land to grow similar crops but individually. In a bid to increase crop production, emphasis shifted from the form production (communal) to production (output). During

\footnotetext{
${ }^{309}$ Coulson, A. 1982. Tanzana: A Political Economy. London: Clarendon Press.
} 
the same time period, civil servants were decentralized to districts and regions to oversee villagization. It was at this juncture realized that political persuasion was not enough to get the peasants to move into villages hence the need for administrative and bureaucratic coercion. It has been argued that villagization without Ujamaa found favor with some civil servants because:

"It was more in line with bureaucratic thinking and with what a bureaucracy can effectively do: enforce movement of the peasants into new 'modern' settlements, i.e. settlements with the houses placed together, in straight lines, along the road, and with the fields outside the nucleated village, organized in blockfarms, each block containing the villagers' individual plots, but with only one type of crop, and readily accessible for control by the agricultural extension officer and eventual cultivation by government tractors." 310

In spite of the implemented changes, agricultural production continued to decline and general economic performance reduced. In 1975 inflation increased to $23 \%$ from $17 \%$ the previous year (see table 5.3 ), and total aid per capita rose from $12 \%$ to $19 \%$ in the same time period. ${ }^{311}$ It has been asserted that "Agriculture was beset by a disastrous combination of forced villagization, accelerated agricultural modernization and 'directives', which significantly reduced agricultural exports and led to major food shortages. ${ }^{312}$ Lofchie (1978) also asserts that reduction in agricultural production and general poor economic performance are attributable to Ujamaa and villagization drives. His research findings show that production of food crops like Maize reduced with

\footnotetext{
${ }^{310}$ Boesen, J. 1976. “Tanzania: From Ujamaa to Villagization.” Institute for Development Research, Copenhagen, Paper A76.7, p. 13. In Coulson, A. 1982. Tanzana: A Political Economy. London: Clarendon Press.

${ }^{311}$ Bigsten, A. et al 1999. Aid and Reform in Tanzania. Washington, D.C: The World Bank.

${ }^{312}$ Raikes, P. and Peter Gibbon. 1996. “Tanzania.” In Engberg-Pedersen, et al. Limits of Adjustment in Africa. Oxford: James Currey, p. 219.
} 
villagization, and food imports rose during the same period. ${ }^{313}$ In his view, the economic crisis is rooted in the "peasantry's unwillingness to produce under socialist conditions. ${ }^{.314}$

Indeed, the economic decline in the mid 1970s was a result of poor government policies and programs. For instance, import substitution programs oriented farming to food crop growing than production of export crops. Consequently, exports drastically reduced at the time that food crop production also reduced. Without any revenue, government found itself increasingly relying on donor aid to pay for imports, thereby increasing the fiscal deficit. It should also be noted that monopolistic parastatals had an adverse effect on crop production and exports. Parastatals especially the marketing cooperatives drained government of revenue. They generously offered grants and loans to Ujamaa villages but rarely got the money back. Moreover, the monopolization of the marketing and distribution of produce opened avenues for corruption, embezzlement of funds, and general ineffectiveness in the parastatals.

\section{Vagaries of Nature:}

Some scholars do not attribute economic failure to government policy. In their view, the economic crisis was caused by vagaries of nature. ${ }^{315}$ Between 1973 and 1975 , the country experienced a long drought that severely affected agricultural production. It

\footnotetext{
${ }^{313}$ For a detailed account see Lofchie, M. F. 1978. "Agrarian Crisis and Economic Liberalisation in Tanzania." The Journal of Modern African Studies, Vol. 16, No. 3, pp. 451-475

${ }^{314}$ Lofchie, M. F. 1978. "Agrarian Crisis and Economic Liberalisation in Tanzania.” The Journal of Modern African Studies, Vol. 16, No. 3, p. 475.

${ }^{315}$ See for instance Weaver, J. H. and Arne Anderson. 1981. "Stabilization and Development of the Tanzanian Economy in the 1970s." In Cline, W. R. and Sidney Weintraub (eds) 1981. Economic Stabilization in Developing Countries. Washington, D.C: The Brookings Institution.
} 
has been asserted that grain production reduced by approximately $30 \%$, and export crops like cotton were equally affected. ${ }^{316}$ However, Lofchie (1978) argues that although there was a drought between 1973 and 1974, there was sufficient rain to generate a good harvest in 1974 and 1975 and the fact that the reverse happened, means that the problem lies with the policies. Nonetheless, in order to encourage food production, and undercut the effects of the drought, the government increased producer prices for food crops. This proved untenable as cash crop production became marginalized. It has been asserted that the "drop in export production prevented the country from capitalizing on the booming export prices in 1976-1977. ${ }^{317}$ Higher import prices exacerbated the crisis because the government deficit increased further.

\section{The Uganda War:}

Tanzania accumulated a huge fiscal deficit because of the role the country played in ousting Idi Amin from power in 1979. It has been observed that in 1978, government spending on defense was $14.6 \%$ of the total budget, but in 1979 , the amount rose to $23.3 \%$. The increase raised the budget deficit from approximately 10\% of GDP in 1977 to $20 \%$ in $1979 .{ }^{318}$ It has been estimated that the total cost of the war was approximately 500 million U.S dollars. ${ }^{319}$ This expenditure depleted the government coffers. In addition, the oil shock of 1979 left the country with a severe foreign exchange shortage that

\footnotetext{
${ }^{316}$ Ibid.

${ }^{317}$ Ibid.

${ }^{318}$ Maliyamkono, T. L. and Bagachwa, M. S. D. 1990. The Second Economy in Tanzania. London: James Currey.

${ }^{319}$ Coulson, A. 1982. Tanzana: A Political Economy. London: Clarendon Press.
} 
adversely affected local manufacturing because the import substitution industries were highly dependent on oil supply. By 1985, the Tanzanian economy was in disarray. Agricultural production had stagnated, the manufacturing industries lacked raw materials, exports were almost non-existent, prices were distorted by faulty macro economic policies and bureaucratic control, and the fiscal deficit was extremely high. "GDP growth, which had averaged more than 5 percent a year from 1970 to 1978 , fell to around zero between 1978 and 1985.",320 Table 5.4 shows that from 1979 to 1985 , per capita income fell consistently, and external debt and inflation increased.

Table 5.4 Trends in Select Economic Indicators for the Period 1979-1985

\begin{tabular}{|l|c|c|c|c|c|c|c|}
\hline & $\mathbf{1 9 7 9}$ & $\mathbf{1 9 8 0}$ & $\mathbf{1 9 8 1}$ & $\mathbf{1 9 8 2}$ & $\mathbf{1 9 8 3}$ & $\mathbf{1 9 8 4}$ & $\mathbf{1 9 8 5}$ \\
\hline $\begin{array}{l}\text { Per Capita } \\
\text { Income Growth (\%) }\end{array}$ & 0.2 & -0.2 & -3.7 & -2.6 & -5.6 & 0.2 & 1.4 \\
\hline $\begin{array}{l}\text { Population } \\
\text { Growth (\%) }\end{array}$ & 3.1 & 3.2 & 3.2 & 3.2 & 3.2 & 3.2 & 3.2 \\
\hline Urbanization (\%) & 13.9 & 14.8 & 15.4 & 15.9 & 16.5 & 17.0 & 17.6 \\
\hline Terms of Trade & 139 & 142 & 129 & 127 & 128 & 131 & 126 \\
\hline $\begin{array}{l}\text { \% of Labor Force } \\
\text { in Agriculture }\end{array}$ & 86.3 & 85.6 & 85.6 & 85.5 & 85.4 & 85.2 & 85.1 \\
\hline Monetary Growth (\%) & 56.9 & 26.9 & 18.1 & 19.5 & 17.8 & 3.7 & 30.3 \\
\hline Inflation (\%) & 12.2 & 26.4 & 22.8 & 25.4 & 23.5 & 30.9 & 28.7 \\
\hline $\begin{array}{l}\text { Gross Investment } \\
\% \text { of GDP }\end{array}$ & 33.6 & 33.1 & 28.6 & 26.0 & 19.3 & 20.2 & 18.7 \\
\hline
\end{tabular}

Source: Bigsten, A. and Andres Danielson. 2001. Tanzania: Is the Ugly Duckling Finally Growing Up? A Report for the OECD Project "Emerging Africa", p. 18.

In spite of these problems, the civil service continued to grow. Without a viable private sector, there was only one source of employment, the government. In a bid to bring services closer to the people, several administrative offices were opened in the

\footnotetext{
${ }^{320}$ Stevens M. 1994. "Public Expenditure and Civil Service Reform in Tanzania." In Rehabilitating Government: Pay and Employment Reforms in Africa. Lindauer, D. and Barbara Nunberg (eds) Washington, D.C: World Bank, p. 63.
} 
districts and regions under the decentralization programs of 1972-1974. Personnel were needed to man the education and health sectors, and other government programs that aimed to advance self-reliance and development. Yeager (1989) asserted that Ujamaa expanded the size of civil service and the TANU bureaucracy and their involvement in the national economy. "Decentralization launched a decade of civil service job creation averaging about 11 percent per annum. ${ }^{321}$ As parastatals proliferated, government employment burgeoned even further. By 1984, parastatal employment alone accounted for 302,000 government workers. ${ }^{322}$ Moreover, the collapse of the East African Community in 1977 compelled the government to take in the displaced workers and to provide services that had until then been offered by the East African Community, further increasing the size of government.

Not surprisingly, as the economy collapsed, the administrative system experienced adverse effects. Salaries lost purchasing power because of run-away inflation, absenteeism increased, corruption emerged, and ultimately, civil service performance declined. Faced with mounting disappointments arising primarily from declining productivity, shortage of basic goods, poor public services, and high inflation, civil servants and large portions of the general population reverted to the clandestine and

\footnotetext{
${ }^{321}$ Yeager, R. 1989. Tanzania: An African Experiment. Boulder: Westview Press, p. 76.

${ }^{322}$ Stevens M. 1994. "Public Expenditure and Civil Service Reform in Tanzania." In Rehabilitating Government: Pay and Employment Reforms in Africa. Lindauer, D. and Barbara Nunberg (eds) Washington, D.C: World Bank.
} 
officially maligned "parallel markets" to carter to their individual subsistence needs and to raise personal incomes. ${ }^{323}$

It has been observed that capacity for administrative efficiency and sensitivity to local needs may have been enhanced through the civil service expansion and decentralization process, but democratic participation was marginalized. ${ }^{324}$ The center controlled and allocated development funds and technical expertise, and the local masses' input was rarely taken into consideration. When forced villagization was introduced, the bureaucracy took on a more coercive character in the quest to implement the policies from above. By 1985, the civil service was viewed as part of the problem; not only was it overextended, it was performing poorly, it was corrupt, and it was a financial drain on the government's limited resources. It is against this background that the country with the support of the WB embarked on an economic recovery program.

\subsection{EMBRACING THE MARKET: THE ECONOMIC RECOVERY PROGRAM IN TANZANIA}

Tanzania was forced to embrace the market because the economic failures caused by Ujamaa socialism and restricted personal accumulation of wealth were blatant. Reluctantly, the government reached an agreement with the IMF in 1986 (the Economic Recovery Plan -ERP) to enforce macroeconomic stabilization. Immediate attention was focused on liberalizing trade so that an appropriate and stable pricing system could be

\footnotetext{
${ }^{323}$ Chege, M. 1994. "Swapping Development Strategies: Kenya and Tanzania After their Founding Presidents." In Political Development and the New Realism in Sub-Saharan Africa. Apter, D. E. and Carl, G. Rosberg (eds) Charlottesville: University Press of Virginia.

${ }^{324}$ Yeager, R. 1989. Tanzania: An African Experiment. Boulder: Westview Press.
} 
attained. This would in turn induce an increase in production of goods. Focus was also placed on reducing inflation. Reducing inflation called for exchange rate adjustment and devaluation of the currency. Further, effort was put into increasing the country's foreign earnings. This was to be done by increasing agricultural production especially the production of export crops like coffee and cotton. Another immediate way to revive the economy was through the rehabilitation of social services. Ultimately, the IMF called on the Tanzanian government to adopt structural adjustment programs, limit expenditure, liberalize the economy, privatize parastatal agencies, and restore fiscal responsibility.

By 1990, winds of change had swept over the Tanzanian economic landscape. The currency had been devalued, foreign exchange bureaus were allowed to operate, and the private sector actively participated in the economy. However, concrete achievements of the economic recovery plan were minor. Increases in agricultural production manifested in the food crops, not the cash crops. Consequently, export revenues increased only marginally from US\$400 million to US\$430 million rather than the targeted US\$630 million $^{325}$, and dependence on donor aid did not diminish. In addition, per capita income increased slightly from $1.4 \%$ in 1985 to $3.1 \%$ in $1990 .{ }^{326}$

In order to keep the momentum, the government entered another agreement with the IMF under the Economic and Social Action Programme (ERPII). The new program proceeded with the former ERP reforms and urged the government to place more effort

\footnotetext{
${ }^{325}$ Raikes, P. and Peter Gibbon. 1996. "Tanzania.” In Engberg-Pedersen, et al. Limits of Adjustment in Africa. Oxford: James Currey.

${ }^{326}$ Bigsten, A. and Andres Danielson. 2001. Tanzania: Is the Ugly Duckling Finally Growing Up? A Report for the OECD Project "Emerging Africa. Uppsala.
} 
on controlling the fiscal deficit and domestic credit by reducing recurrent and development expenditures. However, more focus was placed on institutional and public sector reforms. These included reform of the civil service system, parastatals sector, banking system, and public financial management reform. In addition, while the first ERP had not paid attention to the costs of adjustment, the second one did include measures to protect the rural poor who previously depended on the state for all social services but now had to deal with the market. By 1996, more positive changes began to emerge. Real GDP started to grow and inflation started to fall. The establishment of an independent revenue authority helped in rejuvenating the tax administration system and enhancing revenue collection. Table 5.5 shows trends in some indictors for the years 1996-2003. Table 5.5 shows a consistent increase in real GDP from 4.2 in 1996 to 5.6 in 2003. Inflation that was $21 \%$ in 1996 had been reduced to $4.4 \%$ in 2003 . It can therefore be asserted that by 2003 , the economic reforms had started generating positive changes and the economy was on the way to steady recovery.

It should be noted that in addition to the economic reforms, the country undertook major political reforms. The latter entailed a transition from a single party political system to political pluralism. In 1995 the first multiparty elections were held and won by CCM (Chama cha Mapinduzi) the party that emerged from TANU. It should however be noted that although elections have been held every five years since 1995, CCM is yet to be defeated (nonetheless free and fair). The challenge that the country now faces is how to entrench pluralism and dilute the one party heritage. 
Table 5.5 Trends in Selected Macroeconomic Indicators: 1996-2003

\begin{tabular}{|c|c|c|c|c|c|c|c|c|}
\hline & 1996 & 1997 & 1998 & 1999 & 2000 & 2001 & 2002 & 2003 \\
\hline $\begin{array}{l}\text { Real GDP } \\
\text { Growth \% }\end{array}$ & 4.2 & 3.3 & 4.0 & 4.7 & 4.9 & 5.7 & 6.2 & 5.6 \\
\hline $\begin{array}{c}\text { Inflation - } \\
\text { annual } \\
\text { average \% }\end{array}$ & 21.0 & 16.1 & 12.9 & 7.8 & 6.0 & 5.2 & 4.5 & 4.4 \\
\hline $\begin{array}{c}\text { Export } \\
\text { (US\$ } \\
\text { millions) }\end{array}$ & 763.8 & 752.6 & 588.5 & 543.3 & 663.3 & 776.4 & 902.5 & 1142.4 \\
\hline $\begin{array}{l}\text { Imports } \\
\text { (US\$ } \\
\text { millions) }\end{array}$ & 1212.6 & 1148.0 & 1382.2 & 1415.4 & 1367.6 & 1560.3 & 1511.3 & 1973.0 \\
\hline $\begin{array}{c}\text { Investment } \\
\text { /GDP Ratio } \\
\%\end{array}$ & 16.5 & 14.7 & 16.0 & 15.4 & 17.6 & 17.0 & 18.9 & 18.5 \\
\hline $\begin{array}{c}\text { Foreign } \\
\text { Direct } \\
\text { Investment } \\
\text { (US\$) }\end{array}$ & 148.5 & 157.8 & 72.2 & 516.7 & 463.4 & 327.2 & 240.4 & 247.8 \\
\hline $\begin{array}{c}\text { Foreign } \\
\text { Reserves } \\
\text { (months of } \\
\text { imports) }\end{array}$ & 2.4 & 3.8 & 3.0 & 4.1 & 5.8 & 6.3 & 8.3 & 8.9 \\
\hline & $96 / 97$ & $97 / 98$ & $98 / 99$ & 99/00 & $00 / 01$ & $01 / 02$ & $02 / 03$ & $03 / 04$ \\
\hline $\begin{array}{c}\text { Govt } \\
\text { Domestic } \\
\text { Revenue } \\
\text { (\%of GDP) }\end{array}$ & 13.5 & 12.6 & 12.5 & 11.3 & 12.2 & 12.1 & 12.8 & 13.4 \\
\hline $\begin{array}{l}\text { Total Govt } \\
\text { Expenditure } \\
\text { (\% of GDP) }\end{array}$ & 17.3 & 17.4 & 17.6 & 18.3 & 20.6 & 19.1 & 23.4 & 24.9 \\
\hline $\begin{array}{l}\text { Total Debt } \\
\text { (US\$ } \\
\text { millions) }\end{array}$ & 7578.5 & 7384.6 & 7669.7 & 7624.8 & 7482.1 & 7464.0 & 7268.2 & 7890.7 \\
\hline
\end{tabular}

Source: Rwekaza M. et al 2005. The Political Economy of Tanzania. Dar es Salaam, p. 27.

\subsection{THE PUBLIC SECTOR REFORMS IN TANZANIA}

The ERP reforms opened the way for other major reforms including the public sector reforms. These reforms include macro-economic reform, public finance management reform, sectoral reforms, local government reform, and civil service reform. The macro-economic reforms entail every thing that has so far been done to stabilize the economy as discussed in the sections above. The public finance management reform was 
initiated in order to introduce accountability, transparency, and financial discipline in the management of the country's budget. Its major objectives are to attain efficient allocation of resources, to generate incentives for performance, and to maximize resource allocation. The sectoral reforms aim at generating defined priorities and affordable levels of service provision. In addition, these reforms aim at generating strategies for enhanced private sector participation. Local government reforms are being undertaken within the civil service reform program. They aim at generating efficiency and effectiveness in the delivery of services at the local level through decentralization by devolution. The civil service reform program was implemented in order to "achieve a smaller, affordable, well compensated, efficient, and effective service. ${ }^{327}$ It is not only aimed at revitalizing the bureaucracy, but also to make it capable of implementing all the above reforms.

It should be noted that Tanzanian CSRP has been implemented in phases. Phase 1 focused on cost containment and covered the years 1991-1995 although its implementation spilled over into 1996. Phase 2 focused on institutional and performance management and covered the years 1996 to 2000. Phase 3, implemented under the public service reform program (PSRP) focused on instituting performance management systems and was originally supposed to be undertaken in the period 2000 to 2005 , but implementation continued into 2007. Phase 2 of the PSRP focused on enhancing performance and accountability. It was supposed to cover the period 2005-2007 but implementation only began in 2007. The third phase of the PSRP focuses on instituting

\footnotetext{
${ }^{327}$ United Republic of Tanzania. President's Office-Civil Service Department. 1999. Civil Service Reform Program Implementation Status Report (1993 - 1999). Dar es Salaam, p. 5.
} 
quality improvement cycles and its implementation began in 2008. Figure 5.2 shows the phases.

Figure 5.2 The Phases of the CSRP/PSRP in Tanzania

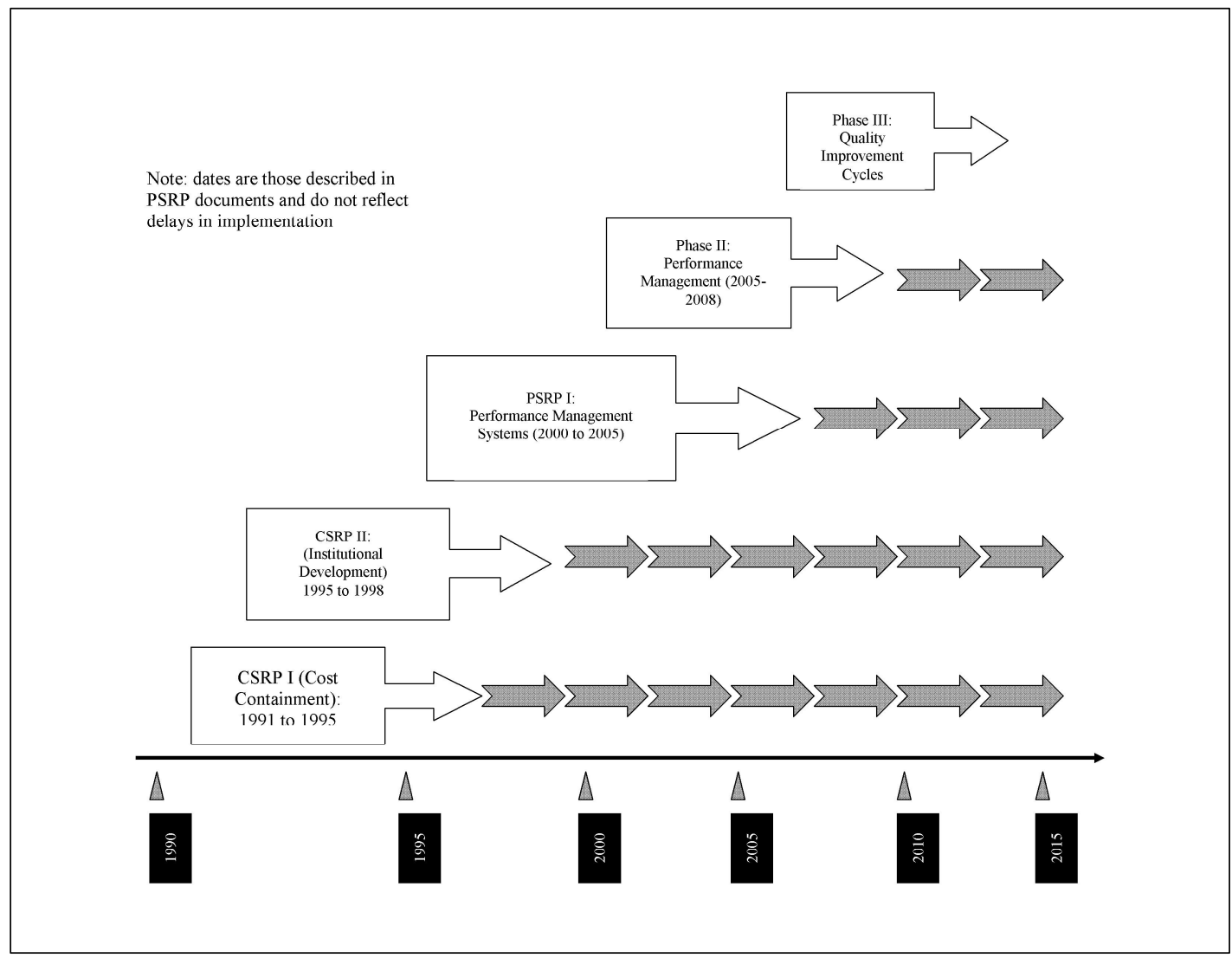

Source: United Republic of Tanzania, President's Office-Public Service Management. 2000. The PSRP 1 Medium Term Strategy. Dar es Salaam.

\subsection{SUMMARY}

The discussion presented above has shown that the adoption of Ujamaa socialism was not conducive to economic growth in Tanzania. This is partly because the policy was built on a factually untenable premise that traditional African societies were inherently socialist. While it is true the traditional African societies communally shared land, and in some instances farmed together (for instance offering one's services in times of harvest), 
they did not practice communal farming and communal sharing of produce. It is no wonder that agricultural production deteriorated and an economic crisis ensued as shown above. It is also not surprising that fast development and self-reliance were never attained. Ultimately, by the time SAPs were initiated, the country was neither socialist nor egalitarian although when compared to Uganda and Kenya, the country was and still is, hailed for being more egalitarian and peaceful. Compared with Uganda, Tanzania's political system has been stable and economic failure was not a result of political chaos.

It has been shown that under SAPs, the economy has been reformed, liberalized, and put on a path to better performance. In addition, other reforms have been undertaken to revitalize service delivery and put the country on a development path. Among them is the civil service reform program. In chapter seven, a detailed analysis of the performance of the Tanzanian CSRP is offered. 


\section{CHAPTER 6: THE CIVIL SERVICE REFORM PROGRAM IN UGANDA: AN ANALYSIS OF THE FINDINGS}

\subsection{INTRODUCTION}

The discussion in chapter five addressed the political and economic turmoil Uganda experienced soon after independence and through the 1970s, 80 s and much of the 1990s. It also discussed the various reform programs including structural adjustment programs comprising administrative reforms, economic reform programs, and political reforms that have been pursued in an attempt to rectify the situation. The Uganda civil service was viewed as a problem rather than a solution to the country's socio-economic and political collapse hence effort was made to build a better and more professional service. The Ugandan government, as in many others in Africa, embarked on various reforms to change the image and functioning of the civil service from an inefficient, bloated, corrupt, and unresponsive one, to a smaller, motivated, accountable, efficient, effective, and responsive one. More than ten years after the Ugandan civil service reform program implementation began, it is useful to assess the impact of the reforms and determine whether they are attaining their goals and objectives.

Chapter six presents the results and analyzes the Ugandan civil service reform program based on the data generated from interviews held with officials from the Ministries of Public Service, Education, Finance, and Local Government and data from official government documents and various websites. The study focused its analysis on four major aspects of the reform program namely; (i) the reduction of the size of the civil service, (ii) pay reform, (iii) capacity building, and (iv) ethics and accountability. The following questions guided this analysis; 1) has the size of the civil service been reduced? 
to what levels? 2) Are the civil servants well paid and motivated? 3) Is capacity being built? In what areas/ways? 4) Are ethics and accountability improving? What are the indicators? Chapter six attempts to answer these questions based on realities on the ground derived from the interviews held with senior government officials and data from the various government documents, published work and the internet. The analysis is based on a case study of four ministries; the Ministry of Public Service (MPS), the Ministry of Education (MOE), the Ministry of Finance (MOF) and the Ministry of Local Government (MOLG). The discussion offered in chapter three indicated that after careful review of the field notes, certain specific salient and similar issues started emerging. The issues that emerged were grouped together and continuously studied until themes and patterns emerged.

The overall themes that emerged from my respondents' perception of the reform program are: doing more with less; improving remuneration; human resources development and capacity building; enhancing ethics and accountability and economic recovery and poverty eradication. These themes are the basis of the analytical discussion of results offered below. The discussion is provided in four major sections and each deals with one of the four aspects of the reform program. Under each section, subsections covering the context before the reform, the goals of the reform, the implementation, and the results of the reforms are provided.

It should be noted that the Civil Service Reform Program in Uganda was undertaken in a phased approach. The first phase was implemented from 1991 to 1997 and it focused primarily on reducing the size of the civil service and improving the salary of the retained civil servants. The second phase guided by the Public Service Reform 
Strategy and called the Public Service Reform Programme (PSRP) covered the years 1997-2002. The program name changed to Public Service Reform in order to be consistent with chapter 10 (ten) article 257 (i) of the Uganda Constitution which defines the Public Service as the service offered in a civil capacity at national government level or at the local government. The second phase focused on reducing further the size of the service by restructuring ministries and departments, pay reform, capacity building, and introduced Results Oriented Management (ROM) system. The third phase still under way, was effected in 2002 to run till 2007. Known as the Public Service Reform Strategy 2002-2007, it focuses on performance management for sustained implementation of Government Programmes especially the Poverty Eradication Action Plan (PEAP).

\subsection{DOING MORE WITH LESS: THE REDUCTION OF THE SIZE OF THE UGANDAN CIVIL SERVICE}

The reduction in the size of the Ugandan civil was one of the comprehensive administrative reform endeavors advocated for by the PSRRC. At independence, Uganda had a very small civil service with minimal responsibilities, a small cabinet, and virtually no parastatal agencies. By the the late 1980s however, the Ugandan civil service was overwhelmed by responsibilities, was extremely bloated, and dysfunctional both in operation and structurally. The 1991 CSRP program therefore sought to reverse this trend. The reduction of the size of the civil service aspect of the reform program focuses on the organizational structure and scope of government. This is in line with the NPM ideals. Four focal areas are common to NPM reforms; (1) restructuring and reengineering of the internal administrative structures, (2) the development of market 
oriented strategies within the public sector, (3) the emphasis of doing more with less, and (4) the emphasis on mechanisms guaranteeing customer service. In Uganda, efforts to reduce the size of the civil service have been focused on rationalizing and restructuring the cabinet or ministries and districts, and on down sizing the service through retrenchment and voluntary retirement.

\subsubsection{Rationalization and Restructuring of Ministries and Districts}

In 1990, the Ugandan civil service was comprised of 38 ministries and employed approximately 320,000 people. The Director of Administrative Reform at the Ministry of Public Service was of the view that this high number of employees was a result of at least three major reasons:

"first, the tradition of providing public sector jobs as a means of safeguarding employment; second, the growth of the state sector into areas of activities which are beyond the government's traditional domain; and third, the nature of the coalition regime put in place by the NRM and the need to provide a role in government for various political allies. ${ }^{, 328}$

Because of the above reasons, she added, the civil service became extremely large and expensive to run, duplication and overlap of functions and responsibilities increased to the extent that in some instances it became very difficult to ascertain where responsibility lay. She was of the view that such ambiguity also led to poor coordination, communication and information flow. According to the Ministry of Public Service, rationalization of ministries and departments and districts was to be undertaken "through

\footnotetext{
${ }^{328}$ Interview held with Ms. Deborah Katuramu, the Director, Administrative Reform, Ministry of Public Service, Uganda, held July 21, 2006. Ms Katuramu has been Director of Administration Reform for the last 10 years.
} 
ministerial and district reviews to streamline the structures and the staffing levels to enable greater efficiency and effectiveness to be achieved in the Service. ${ }^{.329}$ Nolan (2001) asserts that rationalization and down-sizing aim at reduction of the pay rolls of public sector organizations and entail moves to flatter organizational structures buttressed by staff reductions at both upper and lower tiers of organizations. ${ }^{330}$ Indeed, the rationalization processes was initiated in order to reduce the number of ministries to only that necessary to carry out the core functions of government so that financial resources can be saved and used for better remuneration of the staff. According to the Director, Administrative Reform at the Uganda Public Service Ministry,

"When the public service reform started in 1991, the size was over bloated, we were about 320, 000 workforce across the service. By 1997, it had reduced to about 150,000 this was made possible through the various reforms which included down sizing and by down sizing we had to remove the personnel that had entered the service illegally what we call the illegal entrants ...We cleaned the payroll which had ghosts particularly in the teachers payroll........Ministries were reduced from 38 to 22 in July 1991, and eventually to 17 as of today.",331

The views provided by Director, Administrative Reform were further supported by the Commissioner and acting director for Human Resources and Capacity Building at the Ministry of Public Service when she revealed that;

"There has been a fundamental review of the mission, strategic objectives, structure and staffing levels of all ministries and departments of central government as well as district administrations. As a result of these reviews, several ministries were merged, and the number of established posts in the public

\footnotetext{
${ }^{329}$ Government of Uganda, Ministry of Public Service. 1994. Management of Change: Content, Vision, Objectives, strategy and Plan. Kampala: Uganda Printing and Publishing Corporation, p. 25.

${ }^{330}$ Nolan, B. 2001. International Public Sector Reform: An International Perspective. New York: Palgrave.

${ }^{331}$ Interview held with Ms. Deborah Katuramu, the Director, Administrative Reform, Ministry of Public Service, Uganda, held July 21, 2006.
} 
service was substantially reduced. The public service is now oriented to do more with less people and less expenditure, to work better but cost less.",332

The above view is in line with the NPM prescriptions to public administrative systems to adopt management techniques and practices that are prevalent in the private sector, practices that aim at resource conservation while maintaining high standards of service. According to Hood (1991), NPM puts a stress on greater discipline and parsimony in resource use. This means cutting direct costs, raising labor discipline, resisting union demands, limiting 'compliance costs' to business and it is typically justified by the need to check the resource demands of the public sector to 'do more with less., 333

An Implementation and Monitoring Board (TIMB) ${ }^{334}$ was charged with the responsibility of rationalizing and streamlining staffing levels and the review of retrenchment decisions in order to harmonize them with the new ministerial structures and target establishment numbers. ${ }^{335}$ These tasks were undertaken by conducting interviews in the 22 central ministries where personnel was categorized as follows:

- those recommended to stay in the approved positions

- those that are good and suitable but lack approved positions in the reviewed ministries but could be deployed in other ministries or departments and

\footnotetext{
${ }^{332}$ Interview held with Ms.Ada Kabalokele, Commissioner and Acting Director for Human Resources and Capacity Building, Ministry of Public Service, held July 19, 2006.

${ }^{333}$ Hood C. 1991. “A Public Management for all Seasons?” Public Administration. Vol. 69, p. 5.

334 This Board was appointed by the President.

${ }^{335}$ Government of Uganda, Ministry of Public Service. 1994. Management of Change: Content, Vision, Objectives, strategy and Plan. Kampala: Uganda Printing and Publishing Corporation, p. 26.
} 
- those declared redundant and no longer required for employment in government. $^{336}$

According to the Ministry of Public Service, the objective of the ministerial restructuring component of the CSRP was "to develop new efficient and effective structures and establishments for 28 Government bodies including 21 ministries, 5 agencies and 2 institutions, to fill positions and to remove surplus staff." It is asserted further that, "an important element of the ministerial restructuring is to update structures to reflect decentralization." 337 The restructuring of senior positions in the ministries led to the compulsory retirement of ten permanent secretaries. ${ }^{338}$ Table 6.1 indicates the actual and target civil service staffing levels for the years 1990 to 1995.

From table 6.1 , it can be seen that the education sector was to be gradually reduced but it should be noted that the above numbers do not include the institutions of higher learning staff. The target for the size of the teaching service was based on the primary classroom capacity of Ugandan schools which was estimated to be one classroom (approximately 50 students) per teacher. The target size for the police and prisons staff indicates an increase in the size. It was asserted that a police service of

\footnotetext{
${ }^{336}$ Ministry of Public Service. 1994. Ibid, p. 27.

${ }^{337}$ Ministry Of Public Service. 1996. Uganda Civil Service Reform Programme Status Report 8, January 1 - March 3,1 1996, Kampala, pp. 3-4.

${ }^{338}$ Ministry of Public Service. 1994. Civil Service reform Program Status Report 2 October-February 1994. Kampala, p. 6.
} 
25,000 implies a police population ratio of 1 to 700 , a number considered necessary in the current Ugandan circumstances. ${ }^{339}$

Table 6.1 Actual and Target Civil Service Staffing Levels 1990 - 1995.

\begin{tabular}{|l|c|c|c|c|c|c|c|}
\hline & \multicolumn{2}{|l|}{ ACTUAL } & \multicolumn{2}{l|}{ TARGET } \\
\cline { 2 - 8 } & Jul - 90 & Jul - 91 & Jul - 92 & Jul - 93 & Sept - 93 & Jul - 94 & Jul - 95 \\
\hline $\begin{array}{l}\text { Education/ } \\
\text { Teaching } \\
\text { Service }\end{array}$ & 120,000 & 120,000 & 120,000 & 118,000 & 100,000 & 90,000 & 90,000 \\
\hline $\begin{array}{l}\text { Traditional } \\
\text { Civil } \\
\text { Service }\end{array}$ & 70,000 & 40,000 & 36,000 & 32,943 & 29,475 & 30,000 & 30,000 \\
\hline $\begin{array}{l}\text { Police and } \\
\text { Prisons }\end{array}$ & 20,000 & 23,000 & 23,000 & 21,000 & 21,000 & 25,000 & 25,000 \\
\hline $\begin{array}{l}\text { Group } \\
\text { Employees }\end{array}$ & 110,000 & 86,000 & 50,000 & 43,000 & 26,661 & & \\
\hline \multicolumn{1}{r|}{ TOTAL } & 320,000 & 269,000 & 229,000 & 214,943 & 177,136 & 145,000 & 145,000 \\
\hline
\end{tabular}

Source: Government of Uganda, Ministry of Public Service. 1994. Management of Change: Content, Vision, Objectives, strategy and Plan. Kampala: Uganda Printing and Publishing Corporation, p.32.

${ }^{1}$ Group employees are casual workers who could be hired and fired by the line Ministries. They were not permanent or pensionable, although they did contribute to the Social Security Fund.

The Group Employees scheme was slated for complete removal and the table indicates it was going to be done drastically and quickly.

In addition to ministerial reviews, district reviews were also undertaken. According the Director of Administration Reform,

"The purpose of the district reviews was to prioritize objectives and core functions and rationalize organizational structures and staffing requirements of the system of local authorities in thirty nine districts that were to be created by the decentralization policy.", 340

\footnotetext{
${ }^{339}$ Government of Uganda, Ministry of Public Service. 1994. Management of Change: Content, Vision, Objectives, strategy and Plan. Kampala: Uganda Printing and Publishing Corporation, p. 31.

${ }^{340}$ Interview held with Ms. Deborah Katuramu, the Director, Administrative Reform, Ministry of Public Service, Uganda, held July 21, 2006.
} 
The District reviews were undertaken by a task force composed of representatives from the Decentralization Secretariat of the Ministry of Local government, Ministry of Public Service, Ministry of Finance, and Ministry of Education. The review process was divided into three phases where the first phase was to produce discussion drafts setting out the macro structure for each type of district and for Kampala City Council (Kampala is the only City with District Status), while phase two and three were to produce the detailed structure and staffing plans for each of the decentralized districts. As a lead up to phase one, in January 1994, the District Review Task Force (DRTF) organized four regional workshops for all District Executive Secretaries, the Resistance Council Five chairpersons and councilors (RC5s) and Resistance Council Four (RC4s)/Town Clerks and Councilors in Gulu (Northern Uganda), Mbale (Eastern Uganda), Mbarara (Western Uganda) and Mukono (Central Uganda). The aims of the workshops were to identify the key issues for decentralization; to propose the main functions, activities and structures for Districts; and to generate a framework to guide District reviews so similar structures and staffing levels could be evolved. ${ }^{341}$ By the end of the year, all 39 districts were reviewed. ${ }^{342}$

According to the Principal Personnel Officer in the Ministry of Local Government, the district reviews were integral parts of the reform program and were critical in preparing ground for the decentralization process. He asserted that the district

\footnotetext{
${ }^{341}$ Government of Uganda, Ministry of Public Service. 1994. Civil Service reform Program Status Report 2 October 1993-February 1994. Kampala, p. 3.

${ }^{342}$ Government of Uganda, Ministry of Public Service. 1994. Management of Change: Content, Vision, Objectives, strategy and Plan. Kampala: Uganda Printing and Publishing Corporation p. 27.
} 
reviews helped in clarifying the district responsibilities and their relationship with the central ministries for each function. ${ }^{343}$ Rationalization and downsizing in this case therefore entailed a split between a more strategic core, the ministry, and a large operational periphery, the district. The district reviews were a comprehensive and expensive exercise that cost approximately U.S. $\$ 326,940 .^{344}$

\subsubsection{Down Sizing the Civil Service through Retrenchment and Voluntary Retirement}

Retrenchment:

The PSRRC recommended a reduction of the Uganda civil service staff by 34,000 employees. ${ }^{345}$ Focus was to be placed on removal of "overdue leavers" such as who had reached the then mandatory retirement age of 55 years, those who entered the service irregularly, and the non performers who would otherwise have been long let go if the system had been functioning properly. In addition, more reductions were to be effected by removal of ghost workers, the abolition of the group employee ${ }^{346}$ scheme, compulsory retirement resultant from the ministerial reviews, and a voluntary retirement scheme. According to the Ministry of Public Service, the objective of the downsizing component of the CSRP was "to achieve a staffing level within the civil service which is consistent

\footnotetext{
${ }^{343}$ Views expressed by Mr. Ssonko, Principle Personnel Officer, Ministry of Local Government in an interview held on August 10, 2006.

${ }^{344}$ Government of Uganda, Ministry of Public Service. 1994. Civil Service reform Program Status Report 2 October 1993-February 1994. Kampala, p. 5.

${ }^{345}$ The Report of the Public Service Review and Organization Commission Report 1989-1990. Kampala, Government Printer.

${ }^{346}$ Group Employees are casual workers who could be hired and fired by the line ministries. They were not permanent or pensionable, although they did contribute to the Social Security Fund.
} 
with the service delivery objectives, the need for salary enhancement and financial

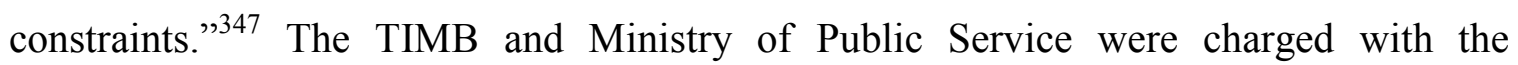
responsibility of sorting out the employees that would qualify for redeployment in the newly restructured ministries and departments. It was planned that between July 1992 and May 1994, a total reduction of 63,000 employees would be achieved ${ }^{348}$ under the categories outlined in Table $6.2^{349}$ below, which also provides the estimated cost of the exercise as well as the source of the funds.

Table 6.2, below indicates that by the end of 1993, 27,000 group employees had been let go. It was anticipated, however, that the abolition of the group employee scheme would result in the retirement of approximately 30,000-35,000 employees by the year 1994 and the non existence of such employees by the end of the same year. ${ }^{350}$ Another notable reduction is the removal of 15,000 ghosts from the teaching service payroll by the end of September 1993. The existence of ghosts on the payroll is indicative of the consequences of the total break down of accountability, institutional, and procedural mechanisms necessary for managing the civil service.

\footnotetext{
${ }^{347}$ Government of Uganda, Ministry of Public Service. 1996. Civil Service reform Program Status Report 8 January 1 - March 31 1996. Kampala, p. 7.

${ }^{348}$ Government of Uganda, Ministry of Public Service. 1994. Management of Change: Content, Vision, Objectives, strategy and Plan. Kampala: Uganda Printing and Publishing Corporation, p. 28

${ }^{349}$ The table has been reproduced with minor changes.

${ }^{350}$ Government of Uganda, Ministry of Public Service. 1994. Management of Change: Content, Vision, Objectives, strategy and Plan. Kampala: Uganda Printing and Publishing Corporation, p. 29
} 
Table 6.2 Planned Action for Fast Retrenchment

\begin{tabular}{|c|c|c|c|c|c|}
\hline CATEGORY & NUMBER & $\begin{array}{c}\text { COST } \\
\text { (USHS Billion) }\end{array}$ & $\begin{array}{c}\text { FUNDED } \\
\text { BY }\end{array}$ & DEADLINE & $\begin{array}{l}\text { STATUS** } \\
\text { FEB. } 94 \\
\end{array}$ \\
\hline $\begin{array}{l}\text { Group Employees } \\
\text { (First } 5 \text { reviewed ministries) }\end{array}$ & 15,000 & $\begin{array}{c}15,000 \\
* \text { Ushs } 0.12 \text { mill. }=1.8 \text { bill. }\end{array}$ & GOU & Sept. 1,93 & Done \\
\hline $\begin{array}{l}\text { Teaching Service } \\
\text { (Overdue Leavers } \\
\text { Approved by TIMB) }\end{array}$ & 3,000 & $\begin{array}{c}3,000 \\
* \text { Ushs } 0.6 \text { mill. }=1.8 \text { bill. }\end{array}$ & GOU & June 30,93 & Done \\
\hline $\begin{array}{l}\text { Group Employees } \\
\text { (First } 17 \text { remaining Ministries) }\end{array}$ & 15,000 & $\begin{array}{c}15,000 \\
* \text { Ushs } 0.2 \text { mill. }=1.8 \text { bill. } \\
\end{array}$ & GOU & Dec. 31,93 & $\begin{array}{c}12,000 \\
\text { Done }\end{array}$ \\
\hline $\begin{array}{l}\text { Voluntary Retirement } \\
\text { (Established Staff) }\end{array}$ & 5,000 & $\begin{array}{c}5,000 \\
* \text { Ushs } 1.6 \text { mill. }=12 \text { bill. }\end{array}$ & Donors & Feb. 31, 94 & In Progress \\
\hline $\begin{array}{l}\text { Remove Ghosts From Payroll } \\
\text { (From Teaching Service) }\end{array}$ & 15,000 & Nil & - & Sept. 31,93 & Done \\
\hline Terminate Licensed Teachers & 5,000 & $\begin{array}{c}5,000 \\
* \text { Ushs } 0.5 \text { mill. }=2.5 \text { bill. }\end{array}$ & Donors & Dec. 31,93 & Done \\
\hline $\begin{array}{l}\text { Retrenchment of Redundant } \\
\text { Established Staff }\end{array}$ & 5,000 & $\begin{array}{c}5,000 \\
* \text { Ushs } 1.5 \text { mill. }=7.5 \text { bill. }\end{array}$ & Donors & May 1994 & In Progress \\
\hline $\begin{array}{l}\text { Total Reduction } \\
\text { by May } 1,1994\end{array}$ & 63,000 & Ushs 17.9 Billion & - & - & $\begin{array}{c}\text { Reduction } \\
\text { Feb. } 1994 \\
45,000^{1} \\
\end{array}$ \\
\hline $\begin{array}{l}\text { Total to be funded } \\
\text { by Donors }\end{array}$ & - & US \$15.6 Million & - & - & - \\
\hline
\end{tabular}

Source: Government of Uganda, Ministry of Public Service. 1994. Management of Change: Content, Vision, Objectives, strategy and Plan. Kampala: Uganda Printing and Publishing Corporation p. 28

${ }^{1}$ The retrenchment strategy for the remaining 18,000 staff to be removed from the payroll by July 1, 1994 was as follow: 1) 4,000 - 5,000 through the Voluntary Retirement Scheme; 2) 5,000 - 9,000 group employees; 3) between 1,000 - 5,000 ghosts from the Teaching Service; and 4) between 1,000 - 5,000 established staff moved out on compulsory basis. ** By Dec. 94, all categories were completed.

Indeed the PSRRC found that whole structure of the civil service had 'ghost workers' but pointed out that the teaching service had the greatest number of them. An official in the Ministry of Education revealed that until recently, the teaching service was one of the most poorly paid government departments and that since prior to the reform program there was no centrally coordinated payroll system, it was easy for Headmasters to fabricate data. ${ }^{351}$

${ }^{351}$ Interview with Mr. J.B Ssemakula, Assistant Commissioner for Personnel, Ministry of Education held August 18, 2006. 
It is however not surprising that such non-existent "workers" were prevalent. It is general knowledge that as the country started to crumble both economically and politically, Ugandan civil servants endured unspeakable hardships resultant from very meager, erratic, and unequal salaries. While some resorted to peddling their skills by taking on three to four jobs - for instance, university lecturers started teaching in high schools, and selling food items like pancakes to university students - others sought for ways to steal from the system and hence the creation of ghost workers. Until the early 1990s, civil servants would take months without receiving their salaries sometimes because it took very long for the government to release the money, but mostly because some influential person was trading with the money or slicing away some chunk for himself or herself in the form of "ghost payment".

As a result of the reform initiatives, by the end of the year 1994, an estimated 42,000 ghost workers had been removed from the payroll and a payroll monitoring unit was established to verify the entry and exit from the payroll. The removal of ghost workers was particularly successful in the teaching service where the payroll was reduced from 120,000 in 1990 to 100,400 in September 1993 and cleaned further to 95,289 in 1994. ${ }^{352}$ However it has been observed by the World Bank that the payroll monitoring was not fully effective and the problem of ghost workers reemerged in 1996 prompting the MPS to conduct an ad hoc investigation that resulted in the removal of about 2,000 ghost workers from the payroll between October 1996 and February 1997. The World Bank asserts that "an improved monitoring system was established in January 1997 in

\footnotetext{
${ }^{352}$ Government of Uganda, Ministry of Public Service. 1994. Management of Change: Content, Vision, Objectives, strategy and Plan. Kampala: Uganda Printing and Publishing Corporation, p. 30.
} 
order to prevent the reoccurrence of ghost workers." ${ }^{353}$ The Assistant Commissioner for Personnel in the Ministry of Education had a similar view when he asserted that it is currently very hard for head teachers to create ghost workers because of the presence of restraint mechanisms. He mentioned the computerization of the payroll system as one of the measures used to monitor the personnel numbers. ${ }^{354}$

\section{Voluntary Retirement:}

Another major way through which the CSRP intended to reduce the numbers of the civil servants was through the voluntary retirement scheme. The voluntary retirement scheme targeted 5,000 employees as indicated in table 6.4 above, including those whose posts were declared redundant as a result of the ministerial reviews and the TIMB assessments. However, civil servants were free to apply for voluntary retirement so long as they were not on temporary employment terms or had not reached the mandatory retirement age of 60 years. $^{355}$ In addition, employees in departments that suffered desperate shortage of staff were not allowed to voluntarily retire for instance doctors and nurses, police and prisons officers, and some qualified primary school teachers were all denied a chance to retire early. The Ministry of Public Service advanced four major reasons to justify the introduction of the voluntary retirement scheme namely:

\footnotetext{
353 Source: Adapted with minor changes from the IMF Staff Country Report No. 98/61, International Monetary Fund. Uganda: Selected Issues and Statistical Appendix, p. 19.

${ }^{354}$ Interview with Mr. J.B Ssemakula, Assistant Commissioner for Personnel, Ministry of Education held August 18, 2006.

${ }^{355}$ The official retirement age used to be 55 years but it was raised to 60 by an Act of Parliament on December 19, 1993 when the NRC passed the Pensions Act.
} 
- it is a quick and equitable way of achieving rapid reductions in staff and maintaining the fast pace of civil service reform to enable the government to move quickly towards the payment of a living wage

- it provides a more humane way of removing staff and limits the level of resentment and grievance of those who leave the service

- as it is optional, those who leave may be more willing to explore opportunities elsewhere and to contribute towards private sector development

- a voluntary scheme should have a lower overall cost, as it avoids most the extensive process of review necessary for compulsory retirement and retrenchment. ${ }^{356}$

Civil servants that were retrenched and those that retired voluntarily enjoyed generous financial packages from the government. According to Director Administrative Reform, the retrenches and retirees were offered a standard safety net payment amounting to $1,000,000 /=$ (one million Uganda shillings - at that time the exchange rate was 1 US \$ to 400 Uganda shillings) as a "golden-hand shake" to assist them establish income generating activities. ${ }^{357}$ More than two thousand dollars was a fairly high amount to the civil servants who were used to earning as little as 30 dollars per month because of the long economic and political crisis the country endured. In addition, those who were

\footnotetext{
${ }^{356}$ Government of Uganda, Ministry of Public Service. 1994. Management of Change: Content, Vision, Objectives, strategy and Plan. Kampala: Uganda Printing and Publishing Corporation, p. 31.

${ }^{357}$ Interview with Ms. Deborah Katuramu, Director, Administrative Reform, Ministry of Public Service, Uganda, held July 21, 2006.
} 
let go were offered a one month basic salary in lieu of annual leave; a severance pay (for permanent and pensionable staff) equivalent to three months basic pay for every one completed year of service up to a maximum of twenty years; committed pensions, gratuity, and monthly pension to those 45 years old and above who were confirmed in the service and served continuously for the last ten years; and transportation (monetary equivalent) to their home districts; while those that used be contract staff were offered twenty five percent of gross emoluments. ${ }^{358}$ The retrenchment costs for both voluntary and mandatory retirement were largely financed by foreign donors, partly the reason why the package was generous especially in the first three years (1994-1996). Table 6.3 below indicates average retrenchment packages for the years 1995-97.

Because of the generous compensation package, the number of applicants for voluntary retirement far exceeded the number set by the reform program. For instance by July 1994, 152,718 applications had been received, yet the target number was approximately $7,000 .{ }^{359}$ Some analysts have asserted that the Ugandan "financial compensation appeared relatively good," ${ }^{360}$ while some have also argued that the package was well received by the retirees. Langseth and Mugaju (1996) assert that some civil

\footnotetext{
${ }^{358}$ Government of Uganda, Ministry of Public Service. 1994. Management of Change: Content, Vision, Objectives, strategy and Plan. Kampala: Uganda Printing and Publishing Corporation, pp. 33-34.

${ }^{359}$ Government of Uganda, Ministry of Public Service. 1994 Civil Service Reform Status Report 2, October 1993-February 1994. Kampala.

${ }^{360}$ See McCourt, W. 1998. "Civil Service Reform Equals Retrenchment? The experience of 'Right-sizing' and Retrenchment in Ghana, Uganda and the U.K." In Minogue, M et al Beyond New Public Management: Changing ideas and Practices in Governance. Cheltenham, UK: Edward Elgar, p. 178.
} 
servants when asked what they thought about the package revealed that "even if I had stayed in the service, I would never have handled that kind of money at a go."361

Table 6.3 Uganda Retrenchment Packages, 1995-1997.

\begin{tabular}{|c|c|c|c|}
\hline & 1995 & 1996 & $\begin{array}{c}1997 \\
\text { Jan. - June } \\
\end{array}$ \\
\hline $\begin{array}{l}\text { Established Employees } \\
\text { Number of retrenched employees }{ }^{1} \\
\text { Retrenchment cost (in millions of U.S. dollars } \\
\text { Package per employee (in U.S. dollars) }\end{array}$ & $\begin{aligned} & 950 \\
& 2.57 \\
2,705.26 & \end{aligned}$ & $\begin{array}{c}4,891 \\
5.46 \\
1,116.34 \\
\end{array}$ & $\begin{array}{c}1,968 \\
1.12 \\
569.11\end{array}$ \\
\hline $\begin{array}{l}\text { Central government } \\
\text { Number of retrenched employees }{ }^{1} \\
\text { Retrenchment cost (in millions of dollars) } \\
\text { Package per employees (in U.S. dollars) }\end{array}$ & $\begin{aligned} & 708 \\
& 2.24 \\
& 3,163.84 \\
&\end{aligned}$ & $\begin{array}{c}12 \\
0.02 \\
1,666.67 \\
\end{array}$ & $\begin{array}{c}0 \\
0.00 \\
0.00\end{array}$ \\
\hline $\begin{array}{l}\text { District Governments } \\
\text { Number of retrenched employees }{ }^{1} \\
\text { Retrenchment cost (in millions of dollars) } \\
\text { Package per employees (in U.S. dollars) }\end{array}$ & $\begin{array}{c}242 \\
0.33 \\
1,363.64\end{array}$ & $\begin{array}{c}4,879 \\
5.44 \\
1,114.98 \\
\end{array}$ & $\begin{array}{c}1,968 \\
1.12 \\
569.11\end{array}$ \\
\hline $\begin{array}{l}\text { Support employees } \\
\text { Number of retrenched employees }{ }^{2} \\
\text { Retrenchment cost (in millions of U.S. dollars } \\
\text { Package per employee (in U.S. dollars) }\end{array}$ & $\begin{array}{c}6,037 \\
0.98 \\
162.33\end{array}$ & $\begin{array}{c}6,840 \\
1.02 \\
149.12\end{array}$ & $\begin{array}{c}3,360 \\
0.50 \\
148.81\end{array}$ \\
\hline
\end{tabular}

Source: Adapted with minor changes from the IMF Staff Country Report No. 98/61, International Monetary Fund. Uganda: Selected Issues and Statistical Appendix, p. 19.

${ }^{1}$ Financed by donors.

${ }^{2}$ Financed by the government of Uganda.

It is partly because of the above generous compensation packages that retrenchment and down-sizing efforts did not generate any social turmoil in the country. Harvey and Robinson (1995) equally assert that retrenchment did not meet resistance because of the attractive severance packages. ${ }^{362}$ Brown et al. (1995) ${ }^{363}$ observe the "lack

${ }^{361}$ Langseth, P. and Justus Mugaju. 1996. Post-Conflict Uganda: Towards an Effective Civil Service. Kampala: Fountain Publishers, p. 72.

${ }^{362}$ See Harvey, C. and Robinson, M. 1995. Economic Reform and Political Liberalization in Uganda. IDS Research Report 29, Brighton: Sussex, p. 15.

${ }^{363}$ See Brown, K. Kithinji Kiragu, and S. Villadsen. 1995. Uganda Civil Service Reform Case Study: Final Report. UK-ODA and Danida. 
of popular uproar" against massive retrenchments in Uganda and it seems this situation is not unique to Uganda. Therkildsen $(2001)^{364}$ asserts that in five eastern and southern African countries, there was typically no protest against down-sizing efforts. Yet, while conducive retirement packages might have had a role to play in this seemingly docile reception towards retrenchment and other down-sizing efforts, it should be kept in mind that generally civil servants are not well organized in terms of collective bargaining efforts. In Uganda in particular, the trade unions are very weak, poorly organized, and not cohesive. It is therefore not surprising that a significant reduction was effected without protest in the CS from 1992-1996.

In July 1998, another special voluntary retirement scheme was launched. The applicants were 2,896 and of that number, 1,179 were approved for retirement. 560 received their due severance packages by December 31 of the same year and the rest in 1999. Table 6.4 below shows the cases that were handled in 1998. It is evident from the table above that more public servants preferred to leave their positions than those actually let go. From 2, 896 applicants, only 1, 879 were approved for early retirement. The generous package is again the reason offered for the "rush" to retire but it has been noted that the economic situation and private sector in the country were beginning to improve and many civil servants were eager to leave public service for the private sector employment. $^{365}$

\footnotetext{
${ }^{364}$ Therkildsen, O. 2001. "Efficiency, Accountability, and Implementation: Public Sector Reform in East and Southern Africa." Geneva: UNRISD Programme Paper 3.

${ }^{365}$ Interview with Mr. Paul Bogere, Assistant Commissioner Human Resources and Development, Ministry of Public Service, held July 19, 2006.
} 
Table 6.4 Summary of the Cases handled under the Special Voluntary Retirement Scheme - 1998.

\begin{tabular}{|c|c|c|c|}
\hline MINISTRY/ DEPARTMENT & $\begin{array}{c}\text { NUMBER } \\
\text { RECEIVED }\end{array}$ & $\begin{array}{c}\text { NUMBER } \\
\text { APPROVED }\end{array}$ & $\begin{array}{c}\text { NOT } \\
\text { APPROVED }\end{array}$ \\
\hline Office of the President & 187 & 40 & 147 \\
\hline Health & 113 & 49 & 64 \\
\hline Mulago Complex & 33 & - & 33 \\
\hline Foreign Affairs & 17 & 12 & 5 \\
\hline State House & 26 & 18 & 8 \\
\hline $\begin{array}{l}\text { Gender Labor and Social } \\
\text { Development }\end{array}$ & 140 & 41 & 99 \\
\hline $\begin{array}{l}\text { Finance Planning and } \\
\text { Economic Development }\end{array}$ & 79 & 33 & 46 \\
\hline $\begin{array}{l}\text { Works, Housing, and } \\
\text { Communications }\end{array}$ & 592 & 462 & 130 \\
\hline Water, Lands, and Environment & 349 & 117 & 232 \\
\hline $\begin{array}{l}\text { Agriculture, Animal Industry, } \\
\text { and Fisheries }\end{array}$ & 616 & 101 & 515 \\
\hline Education and Sports & 189 & 42 & 147 \\
\hline Judiciary & 77 & 20 & 57 \\
\hline Tourism, Trade, and Industry & 128 & 92 & 36 \\
\hline Audit & 6 & - & 6 \\
\hline Judicial Service Commission & 2 & 2 & 0 \\
\hline Local Government & 42 & 20 & 22 \\
\hline Internal Affairs & 20 & 11 & 9 \\
\hline Police & 57 & - & 57 \\
\hline Prisons & 6 & - & 6 \\
\hline Office of the Prime Minister & 64 & 45 & 19 \\
\hline Public Service & 37 & 21 & 16 \\
\hline Education Service Commission & 15 & 7 & 8 \\
\hline Public Service Commission & 7 & 4 & 3 \\
\hline Justice and Constitutional Affairs & 18 & 3 & 15 \\
\hline Energy and Mineral Development & 48 & 24 & 24 \\
\hline Defense & 28 & 15 & 13 \\
\hline TOTAL & 2,896 & 1,179 & 1,717 \\
\hline
\end{tabular}

Source: Government of Uganda, Public Service Reform Programme. Report for the Year 1998. Administrative Reform Secretariat, Ministry of Public Service, Kampala, Appendix E.

It has been asserted that "the applicants that were not approved were mainly persons whose services Government considered were still necessary."366

\footnotetext{
${ }^{366}$ Government of Uganda, Public Service Reform Programme. Report for the Year 1998. Administrative Reform Secretariat, Ministry of Public Service, Kampala, p. 6.
} 
The down-sizing efforts in the Ugandan CSRP generated a tremendous reduction in the staffing levels of the civil service especially between the years 1992-1996. By the end of 1998, the civil service which in 1990 had 350,000 was reduced to 165,724 persons. Table 6.5 and figure 6.1 show how the workforce was reduced.

Table 6.5 The Size of the Civil Service (old definition) for the Years 1990-1998

\begin{tabular}{|c|c|c|c|c|c|c|c|c|}
\hline & Jun - 90 & Jun - 92 & Jun - 94 & Jun - 95 & Jun - 96 & Jun - 97 & Jun - 98 & Dec - 98 \\
\hline $\begin{array}{l}\text { Police and } \\
\text { Prisons }\end{array}$ & 31,000 & 26,826 & 26,390 & 26,894 & 19,679 & 19,341 & 18,441 & 18,232 \\
\hline $\begin{array}{l}\text { Teaching } \\
\text { Services }\end{array}$ & 148,500 & 114,000 & 99,190 & 92,633 & 90,494 & 91,759 & 99,036 & 105,482 \\
\hline $\begin{array}{l}\text { Traditional } \\
\text { Civil Service }\end{array}$ & 140,500 & 94,800 & 51,675 & 37,276 & 48,796 & 46,089 & 43,379 & 42,010 \\
\hline TOTAL & 320,000 & 235,626 & 177,255 & 156,803 & 158,969 & 157,189 & 160,856 & 165,724 \\
\hline
\end{tabular}

Source: Government of Uganda, Public Service Reform Programme. Report for the Year 1998. Ministry of Public Service, Administrative Reform Secretariat, Kampala, Appendix F.

Note: The old definition of the civil service excludes districts' locally hired staff.

On the basis of table 6.5 and figure 6.1 offered below, it can be asserted that the first phase of the CSRP did indeed achieve its goal of reducing the size of the civil service. From 320,000 in 1990 to 165,724 in 1998 , the size of the service was reduced by almost 50 percent. Many scholars and analysts applauded the staff reduction efforts. Langseth (1995) asserted that "the achievements of the CSRP have been impressive." He asserted that the size of the civil service had been reduced dramatically in four years from 320,000 to 150,000 . In his view, the CS was streamlined by redefining the role of government and by reducing the number of ministries and departments from 38 to $21 .{ }^{367}$

\footnotetext{
${ }^{367}$ Langseth, P. 1995. "Civil Service Reform in Uganda: Lessons Learned.” In Public Administration and Development, Vol. 15, pp.365-390.
} 
Figure 6.1 The Size of the Civil Service for the Years 1990-1998

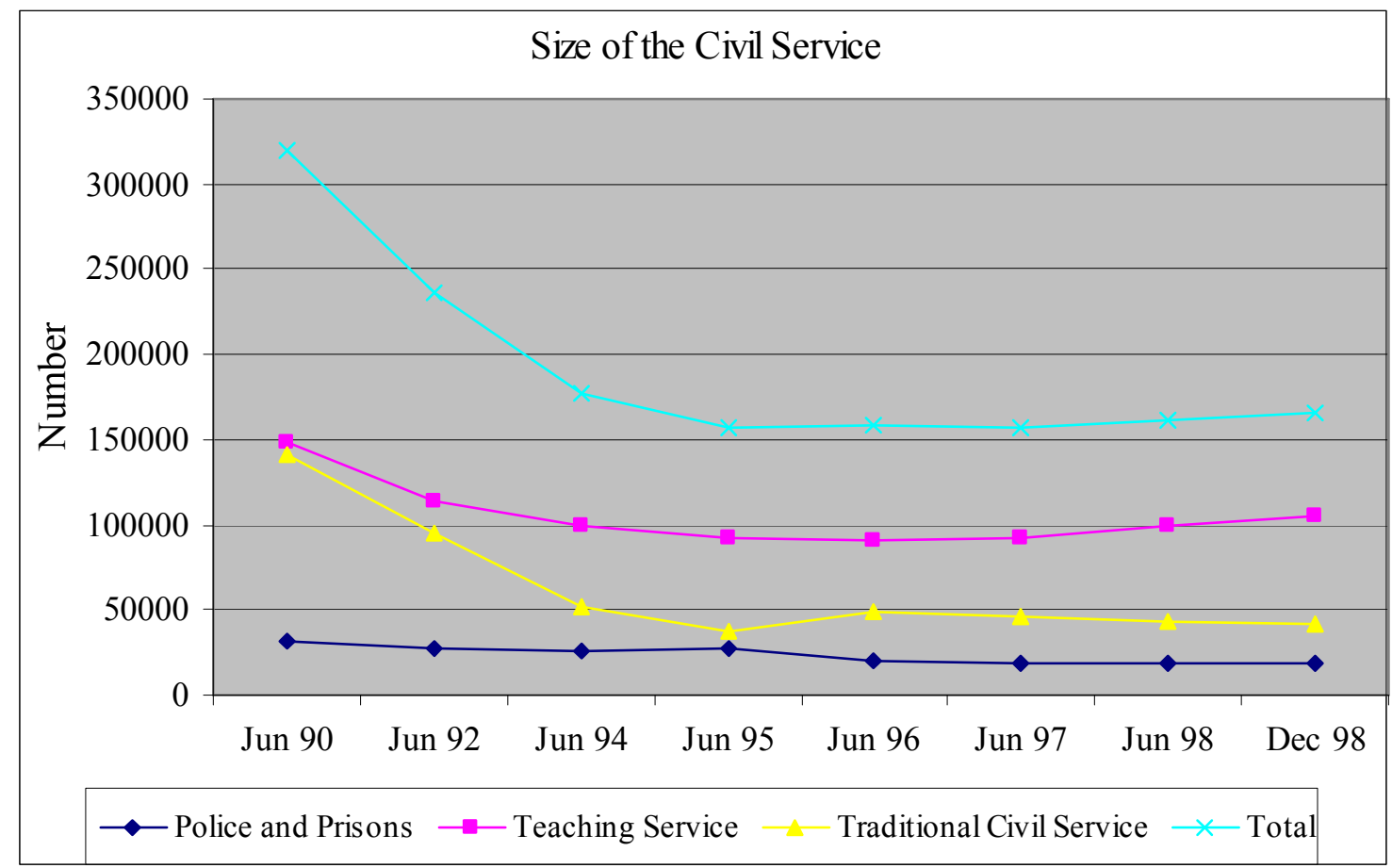

Source: Government of Uganda, Public Service Reform Programme. Report for the Year 1998. Ministry of Public Service, Administrative Reform Secretariat, Kampala, Appendix F.

McCourt (1998) also believes that Uganda has been a "right-sizing success" but questions whether civil service reform simply equals retrenchment. ${ }^{368}$ Clarke and Wood (2001) also applaud Uganda's efforts at staff reduction by asserting that the main achievement of the CSRP has been significant staff reductions. ${ }^{369}$ Kjaer (2004) added her voice to the many cheerleaders of the Uganda CSRP staff reduction efforts by asserting that "The Uganda government was able to cut its public service by half .... And most retrenches were well compensated with considerable retrenchment packages. ${ }^{\prime 370}$

\footnotetext{
${ }^{368}$ See McCourt, W. 1998 Ibid, pp. 172-187.

${ }^{369}$ Clarke, J. and David Wood. 2001. Ibid, pp. 70-89.

${ }^{370}$ Kjaer, A. M. 2004. “Old Brooms can Sweep too! An Overview of Rulers and Public Sector Reforms in Uganda, Tanzania and Kenya." In the Journal of Modern African Studies, Vol. 42, No. 3, pp. 389-413.
} 
The above positive appraisals of the first phase of Uganda CSRP are indeed credible because the size of the service did fall, but from table 6.5 and figure 6.1 above, it can be clearly seen that while the total number of the staff in the traditional civil service and police and prisons has declined consistently, the reverse has happened with the teaching service. Estimated at 148,500 in 1990, the teaching service was at its lowest level in June 1996 at 90,494. However, during the presidential election held the same year, the incumbent pledged during the campaign to offer free universal primary education (UPE) for all school going children six years old and above. The fulfillment of his pledge necessitated an increase in the number of primary school teachers and by the end of the year 1998 the number had risen to 105,482 .

\subsubsection{Challenges in the Reduction of the CS Size}

Many of the participants interviewed in the study were of the view that the gains generated by reducing the size of the CS in the first five years of reform implementation are gradually being eroded by the growth of the overall number of public servants. Some of the reasons identified as causing the increase in staff numbers include UPE, formation of agencies, establishment of new districts, and increase in the number of ministries. According to the Director Administrative Reform, Ministry of Public Service,

"In the middle of 1997, the number began to rise again as a result of other policy developments particularly by UPE which necessitated getting more primary teachers, the plan for modernization of agriculture which necessitated more extension workers, and other areas that came in as and when government made other policy changes. So those contributed to the increase in number. Then like two years ago, we had new districts coming on board which have also contributed to increasing the numbers and of course the costs, so the intentions which we had in 1991 we have had factors militating against them and therefore the number has gone up and certainly the cost has gone up especially the administrative cost." 
The UPE program is perceived as a major government mission to "eradicate illiteracy, while equipping every individual with the basic skills and knowledge with which to exploit the environment for both self and national development." ${ }^{\text {"371 }}$ The Assistant Commissioner Planning and Budgeting, Ministry of Education, viewed the UPE program as a great achievement for the country thus; "It is gratifying that since 1997, when UPE was launched, the total primary school pupil enrollment has risen from almost 3 million to a phenomenal 7.6 million as of 2003. Not surprisingly UPE has generated an equally big increase in the number of teachers required and in turn an increase in the government expenditure on education, something that the reform program had not anticipated. The number of teachers on the payroll increased from 81,564 in 1996 to 122,904 by June 2003." He added, "Out of the total education sector budget of 505.17 billion shillings for financial year 2002/2003, the primary education sub-sector alone was allocated 336.18 billion shillings, representing a share of the 66.5 percent of the total budget for recurrent expenditure. ${ }^{372}$ All the participants I interviewed appreciated the importance of the UPE program but they also indicated that it was introduced in haste, the administrative reform secretariat and Ministry of Finance Planning and Economic Development were not given enough time to prepare for the implications of the implementing such a big program on the over all reform process, and one person

\footnotetext{
${ }^{371}$ Government of Uganda, Ministry of Education and Sports. 2004. Enhancing UPE: A Stakeholders Handbook. Kampala, p. 3.

${ }^{372}$ Interview with Mr. Godfrey Arnold Dhatemwa, Assistant Commissioner Planning and Budgeting, Ministry of Education, Uganda. Held July 26, 2006.
} 
indicated that UPE had worked against the reform efforts geared towards pay increases, a point I elaborate further on under the pay reform section.

Because the education sector was notorious for "ghost workers" prior to the reform implementation, I was keen to know how massive recruitment of teachers was being handled. The Assistant Commissioner for Personnel in the Ministry of Education and Sports revealed that the number of teachers has indeed increased but systematically, based on total pupil enrollment. He said; "Before we were growing any how, currently we grow by formula. We utilize the student teacher ratio which is scientifically determined and as long as you have that, it becomes easy to monitor the teacher payroll and keep abreast with the numbers. Currently the teacher student ratio is one to fifty so a school with 500 pupils should have ten teachers and nothing less or nothing more..."373

The size of the Uganda CS has also increased because of the establishment of semi-autonomous public service agencies. The rationale for establishing the agencies was to that allowing them autonomy would foster efficiency, income generation, and better service delivery. International financial institutions and donor agencies have all advocated the establishment of agencies. Caulfield (2006) agrees when she asserts that "one widely held view among the donor community is that the executive agency is good for developing countries in that it can manage its affairs in a businesslike way, free from political interference in day-to-day operations." ${ }^{374}$ There are over one hundred

\footnotetext{
${ }^{373}$ Interview with Mr. J.B. Semakula, Assistant Commissioner for Personnel, Ministry of Education and Sports, Kampala. Held August 18, 2006.

${ }^{374}$ Caulfield, J. 2006. "The Politics of Bureau Reform in Sub-Saharan Africa." Public Administration and Development, Vol. 26, p. 22.
} 
autonomous and semi autonomous public bodies and public enterprises in Uganda - see Appendix 3 for the list as of 2006. Generally, these agencies have their own statutes, have their own boards, their own salary scales, but get funds from the government consolidated fund in addition to the ones they raise on their own. ${ }^{375}$ Although they are divested from the ministries, they operate under the framework of principle-agent relationship between the agency management board and the parent ministry.

While the government may have been optimistic in establishing the agencies, many of the participants I interviewed did not have a good perception about their establishment, functioning, and over all effect on the CSRP. They decried the manner in which the agencies instead of being self sustaining depend on government, recruit staff without regard to the CSRP ideals, and worsen salary disparity in government employment. ${ }^{376}$ The participants did not challenge the potential usefulness of the agencies but asserted that their set up was not properly done. It was indicated that issues pertaining to performance measurement were not accorded due attention, and that effort was not made to ensure that duplication of roles and responsibilities did not arise. ${ }^{377}$ Therefore, in the pursuit of other programs, the Uganda government has diverted from the original goals of the reform with various consequences some detrimental to staff reduction, pay reform, and even overall efficiency of the service. The views reinforce the fact that while

\footnotetext{
${ }^{375}$ Many of the study participants interviewed were of the view that most of the agencies do not have income generating activities to sustain themselves and so are a burden to the government.

${ }^{376}$ Interview with Ms. Deborah Katuramu, Director, Administrative Reform, Ministry of Public Service, Kampala, Uganda, held July 21, 2006.

${ }^{377}$ Interview with Mr. Kenneth Mugamba, Commissioner Budget Policy and Evaluation, Ministry of Finance, Planning and Economic Development, Kampala, Uganda, held July 17, 2006.
} 
initial success was realized in staff reductions in the first few years of the reform, intervening programs have gradually undermined that success and generated unforeseen problems.

Another reason that size has continued to grow is because of the establishment of more and more Districts at the local level. The Districts were established under the decentralization policy framework initiated in 1991. The policy aimed "to make local governments effective centers of local and democratic decision making for planning, implementation and management of development services." ${ }^{378}$ According to the Undersecretary, Finance and Administration, Ministry of Local Government, prior to decentralization, the Ministry of Local Government was the epitome of government centralization.

"It was a huge ministry which used to handle almost everything that used to take place in the local governments but then from the center for example they used to handle primary education, there was a department of primary education here, there was a department of feeder roads headed by an engineer, there was a department of primary healthcare, essentially all ministries' offices currently at the local level had offices here. When they decentralized, they left skeleton staff at the headquarters and also streamlined all the other services to the ministries where they belong.... They left primary healthcare to health, education went to education, so the ministry of local government remained with a skeleton staff to handle administration of local governments.",379

Although Districts under the decentralization program, are supposed to generate

their own funds, hire and fire their staff, and carry out their duties with reasonable central government support but free of its interference, in reality many of them rely on

\footnotetext{
${ }^{378}$ Government of Uganda, Joint Annual Review of Decentralization 2004. Ministry of Local Government, Kampala, p. 1.

${ }^{379}$ Interview with Mrs. Monica Kalemba, Undersecretary, Finance and Administration, Ministry of Local Government, Kampala, Uganda. Held July 25, 2006.
} 
government funding for their functioning. At the start of the CSRP Uganda had 39 districts, in 1997 they increased to 44, in 2000 twelve more were created raising the number to 56, in 2005 twenty two more were created to reach a total of 78 and as of July 2006, the number had risen to 80 Districts. At face value, one might think that the creation of districts is good for governance and service delivery since it means more services are brought closer to the people. Yet in administrative and economic terms, the creation of more Districts leads to expansion of the public service because a district bureaucracy has to be established.

In general, a district bureaucracy is composed of the District Service Commission headed by a Chairperson that hires the staff. The District is headed by the Chief Administrative Officer who works hand in hand with the various district heads of departments. Every ministry in Uganda has a department at the district level. In effect, every district established necessitates more fiscal expenditure, more staff, and even more politicians. In Uganda, every District is divided into a County, Sub-county, Parish and Village. All the five levels have elected politicians, and career public servants are found at the district level and county level. In addition as per the Uganda Constitution, every district has to have a woman member of Parliament and every county has a parliamentarian. An observer lamented in one of the daily newspapers in Uganda about the reckless establishment of districts. In his article "Can Uganda's Economy Support More Districts?" Denis Ocwich asserted that "in 2005, it costs government between sh685m and sh $1.031 \mathrm{~b}$ to pay wages of district civil servants (excluding teachers), 
annually depending on the size of a district." ${ }^{, 380}$ It was similarly revealed that in the year 2003/2004 the local government transfers constituted about 38.5 percent of the total national budget as compared with 18 percent for the years $1997 / 98 .^{381}$

The formation of districts has been criticized as a political ploy to garner popular support for the local masses. Indeed, all the new districts seem to be awarded just prior to national presidential elections - 1996, 2000, 2005. An officer from the Ministry of Local Government who spoke to me in confidence said that;

"The manner in which districts are being formed is simply ridiculous. Many of the new districts have been curved from mere counties without any income generating capabilities. What is the point of forming a district with a population of less than 30,000 people that has no property to boast of, even no trading center? The way I see it politicians create districts in order to appease their constituencies so that they can be reelected. They make empty promises of more health clinics, more schools etc... In reality, all that cannot be realized because these new districts have to start from scratch and rely on government grants which are often conditional. In my view, its time we started another reform to reform the current civil service reform." 382

The above discussion shows that there is back-tracking and politics is trumping the reform goals. It can therefore be asserted that political commitment to adhere to the original goals of the reforms has waned. Indeed both the UPE and establishment of districts are viewed by many civil servants as political tools used to popularize the Museveni government.

\footnotetext{
${ }^{380}$ Denis Ocwich. 2005. "Can Uganda's Economy Support More Districts?” In the New Vision, Monday, 8th August, 2005.

${ }^{381}$ Interview with Mrs. Monica Kalemba, Undersecretary, Finance and Administration, Ministry of Local Government, Kampala, Uganda. Held July 25, 2006.

${ }^{382}$ Interview No. DW 0010, held August 10, 2006.
} 
Efforts to keep the size of the service low have also been sabotaged by the establishment of new ministries and appointment of what has been termed a political bureaucracy. According to Robinson (2006) "There has been marked growth in recent years in what might be termed the political bureaucracy, comprising officials and advisors in the State House (Office of the President), the Office of the Prime Minister (OPM), the Movement Secretariat, central government ministers and district resident commissioners....There has been a large expansion in the number of presidential advisers, currently estimated to be $72^{, 383}$ In his view, it is no wonder that the overall number of the public servants has grown. Here again it is evident that political considerations are undermining the reform program.

\subsubsection{The Reduction of the Size of the Ugandan CS: Rhetoric or Reality?}

The analysis presented above shows that the CSRP was committed to reducing the size of the Uganda CS. It has been shown that the reduction was effected through various ways among them; rationalization and restructuring of ministries and districts, retrenchment, and voluntary retirement. It has been shown that from 1991 to 1995, the CSRP was rigorous, had great momentum, and managed to drastically reduce the size of the civil service. Ministries were reduced from 38 in 1991 to 17 in 2006, and the traditional CS which was 140,500 in 1990 was reduced to 41,730 in 2004 . These findings confirm Robinson's (2006) assertion that "success in the civil service reform resulted from downsizing and rationalizing the bureaucracy, reflected in a reduction in the number

\footnotetext{
${ }^{383}$ Robinson, M. 2006. "The Political Economy of Governance Reforms in Uganda.” IDS Discussion Paper 386, p. 18.
} 
of civil servants and ministries." ${ }^{384}$ However, after the introduction of the UPE program in 1996, the control over size loosened and the subsequent political machinations manifest in the creation of more districts and incessant hiring of political staff have made it even harder to sustain the positive trend set in the early 1990s. Table 6.6 below shows the growth trend in the size of the public service from 1999 to 2004.

Table 6.6 The Size of the Public Service June 1999 - June 2004.

\begin{tabular}{|l|c|c|c|c|c|c|}
\hline & Jun - 99 & Jun - 00 & Jun - 01 & Jun - 02 & Jun - 03 & Jun - 04 \\
\hline $\begin{array}{l}\text { Traditional } \\
\text { Civil Service }\end{array}$ & 42,557 & 41,176 & 41,260 & 41,282 & 40,328 & 41,730 \\
\hline $\begin{array}{l}\text { Teaching } \\
\text { Services }\end{array}$ & 106,396 & 108,438 & 122,530 & 139,947 & 146,848 & 150,534 \\
\hline $\begin{array}{l}\text { Local } \\
\text { Governments }\end{array}$ & 37,682 & 38,054 & 38,609 & 39,303 & 41,049 & 41,049 \\
\hline & 186,635 & 187,668 & 202,399 & 220,532 & 228,225 & 233,313 \\
\hline
\end{tabular}

Source: Government of Uganda, Ministry of Public Service. 2003. Public Service Reform Program Annual Report for the Financial Year 2002/03. Kampala, p. 59

Table 6.6 shows that while the traditional public service numbers have been relatively steady, those of the teaching service and local governments have been increasing. The study participants agreed that the increase in the number of teachers is justified and commended government efforts to increase literacy, but they perceived the increase in the local government staff as unnecessary. Figure 6.2 below shows the reduction and growth pattern of the civil service.

\footnotetext{
${ }^{384}$ Robinson, M. 2006, Ibid, p. 31.
} 
Figure 6.2 Size of the Ugandan Civil Service 1990 - 2004

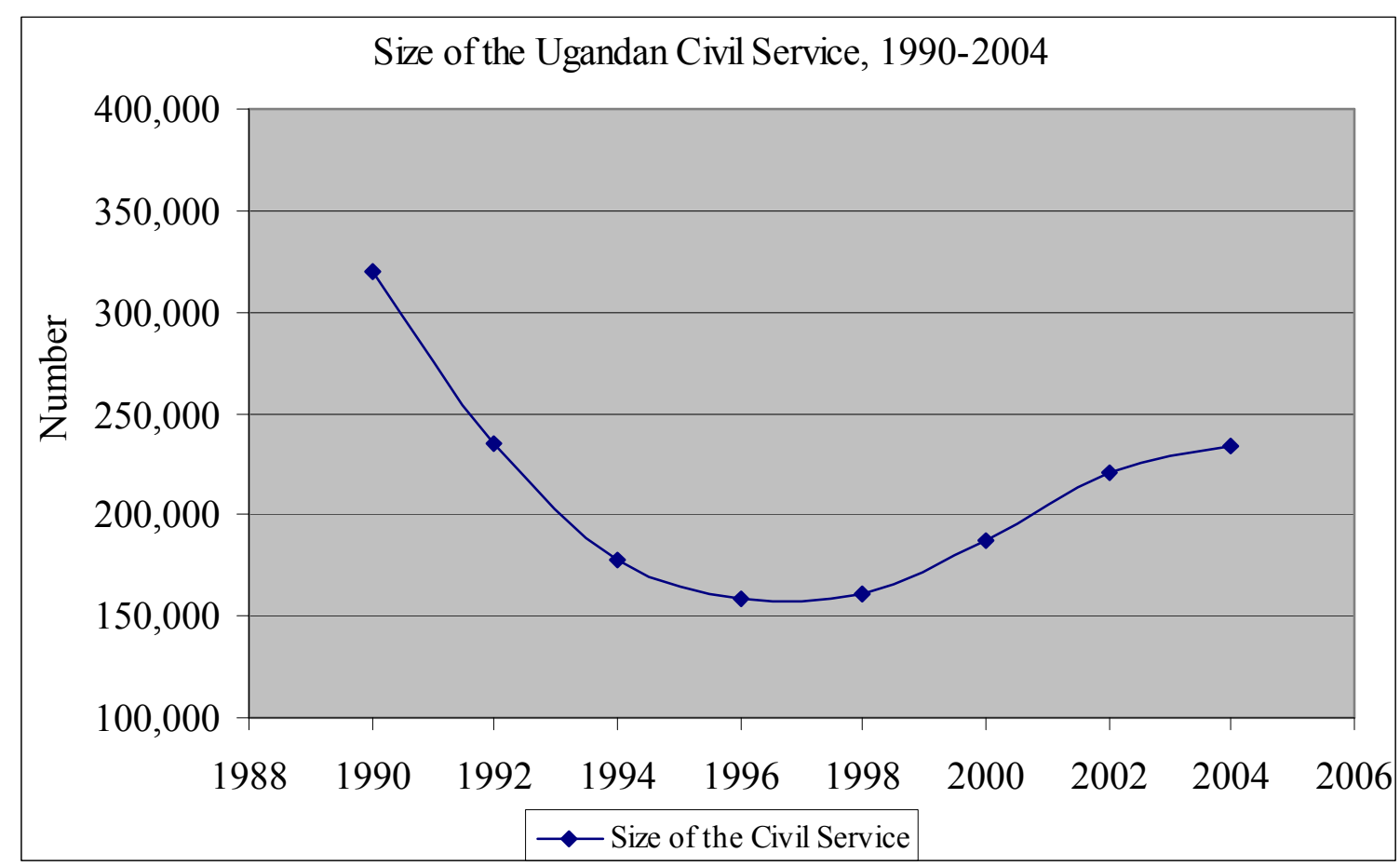

From the above figure the dramatic reduction and gradual increase of the total number of the civil servants is evident. It can therefore be asserted that the initial momentum of the reform has not been sustained and civil service is once again expanding. Yet, when compared to the one prior to the reform in 1990, the current size shows that the reduction has been successful. Indeed, the rhetoric has been turned to reality.

\subsection{IMPROVING REMUNERATION: THE POLITICS OF PAY REFORM IN THE UGANDA CSRP}

Salaries and wages are among the many terms and conditions of civil service employment under review in various countries. While pressure has been brought to bear on many developing countries to reduce the cost of administrative systems with emphasis 
placed on size and expenditure reduction, it is recognized that reducing government expenditure should not be at the expense of enticing qualified and experienced people to seek and retain government employment. In many developing countries, civil service salaries were high in the period immediately before and after independence. In Africa, an ILO study found that this trend was reversed between 1975 and 1985 during which period the average basic salary fell by about 30 to 40 percent. $^{385}$ The CS in Uganda which at independence was lean, efficient, well-paid and highly motivated, was by 1970 in total disarray as chapter 5 illustrated and had one of the poorest pay in Africa. In 1990, the PSRRC reiterated what was already common knowledge, that the civil service bureaucracy was extremely dysfunctional with "abysmally low salaries and wages." 386 It was recognized that improving worker incentives was critical for a more effective civil service.

The commission therefore recommended that government improve the salary and morale of government workers by following four reinforcing steps;

- Government should pay a Minimum Living Wage (MLW) to its employees to enable the worker to afford a basket of goods and services "needed to keep the body and soul together".

- Pay a Living wage that exceeds the MLW to enable the worker to produce such other basic needs as health, children's education, transport and appropriate clothing

\footnotetext{
${ }^{385}$ See Robinson, D. 1990. “Civil Service Remuneration in Africa.” International Labour Review, Vol. 129, No. 3, pp. 371-386.

${ }^{386}$ The Public Service Review and Reorganization Commission Report, 1990, Kampala, Uganda.
} 
- Pay an appropriate national wage that is commensurate to the qualifications, experience, job responsibilities, and performance of the employee. This wage would enable employees to save and invest; and

- Finally the entire service should be accorded at a regional (Africa-Wide Preferential Trade Area) appropriate wage that would place Ugandans at par with their counterparts in the region. ${ }^{387}$

However, the PSRRC found that there were many pertinent issues that needed to be streamlined in pay reform before a MLW could be offered. One of the issues was the pay and grading system. The entire CS pay and grading system consisted of 64 different grades, which made the grade range extremely narrow. As a result, the incentive scope of the structure was severely limited since progression through the pay points was almost worthless to salary increases. Second, progression through the salary scale at grades below U1 which is the highest grade in the CS was based on length of service which did not allow scope for rewarding those that performed above average. Third, the overall grade structure was too compressed with a ratio of 1:6. The compressed ratio prevented the system from adequately differentiating among the real value of the various service jobs such that even promotion could not improve prospects for better pay. Lastly, pay distortions were exacerbated by 76 different types of allowances paid to civil servants. Among them are housing allowances, transport allowances, lunch allowance and professional allowances. The multitude of allowances generated many problems ranging from when they should be paid, to whom, through which methods, administrative

\footnotetext{
${ }^{387}$ Ibid.
} 
intricacy and leeway for abuse. Pay reform therefore had to deal with all the above issues and proceed to implement the recommendations of the PSRRC.

According the Ministry of Public Service, the objective of pay reform within the CSRP was "to rationalize the pay structure of civil servants, reduce or eliminate the noncash elements of remuneration and achieve a living wage. In the longer term, when resources permit, the objective is to introduce a motivational, performance related “optimal" pay structure." 388 The pay reform component of the CSRP sought to attain a LW for the workers by dealing with the incongruent aspects of the salary structures and procedures. Particular focus was placed on elimination of distortions in the pay grading system and the elimination of allowances and benefits. Table 6.7 shows the major problems that pay reform was to address and the manner in which they were to be handled.

Table 6.7 Major Problems in the Civil Service Pay and Envisaged Solutions

\begin{tabular}{|l|l|}
\hline \multicolumn{1}{|c|}{ PROBLEM } & \multicolumn{1}{c|}{ HOW IT WAS ADDRESSED } \\
\hline Inadequate Pay Across the CS & Pay Enhancement Across the Board \\
\hline $\begin{array}{l}\text { Design Weakness in Pay and } \\
\text { Grading System }\end{array}$ & $\begin{array}{l}\text { Job Evaluation and Rationalization } \\
\text { of the System }\end{array}$ \\
\hline Compressed Salary Structure & Decompression and Pay Differentials \\
\hline Ad hoc Allowances & Monetization and Consolidation \\
\hline $\begin{array}{l}\text { Incongruence Between Pay } \\
\text { and Performance }\end{array}$ & Performance Related Pay \\
\hline
\end{tabular}

\footnotetext{
${ }^{388}$ Government of Uganda, Ministry of Public Service. 1993. Civil Service Reform Status Report 1. Kampala, Uganda, p. 16.
} 
Pay reform is a critical component of civil service reform program in Uganda and remains the most challenging. Little progress has been attained in improving the civil servants' salaries. Compared with the reduction of the size of the CS component, evidence shows that the success attained in reducing the CS size has not been as forthcoming in improving salaries and wages. When the reform was initiated in 1991, it was envisaged that the savings made from reducing the size of the service would be used to offer better remuneration packages. And for a while, salaries were enhanced as depicted below. However, the increases have not been consistent and the gains of size reduction have been reversed with the increase in the teaching primary school staff, an issue that has negatively impacted the pay reform program. Evidence generated from the interviews and government documents indicates that while some progress has been made, the major goal of pay reform, the payment of a living wage, has not been attained.

\subsubsection{Salary Enhancement: The Pursuit of the Minimum Living wage}

The Minimum Living Wage (MLW) recommended by the PSRRC was based on a cost of living survey undertaken in 1989-1990 (also known as the food basket survey that included food, shelter, transport, and school fees expenditures) which provided that the lowest grade junior civil servant (U7) should be paid 70,000 Uganda shillings per month (The Uganda shilling/dollar exchange rate was 800/1). According to the Director of Administrative Reform in the Ministry of Public Service, "the government accepted the PSRRC recommendations for improving the remuneration structure and is committed, as resources permit, to a phased progression towards a level of total emoluments that is commensurate with the qualifications, experience, and responsibilities of civil 
servants. ${ }^{389}$ Indeed, Government was keen to show commitment to enhance the salaries that in the financial year 1991/92 civil service salaries were increased by $43 \%$ across board, in the 1992/93 financial year an $85 \%$ increase on basic pay was awarded, and in the 1993/94 financial year, a $37 \%$ increase in the overall wage bill was approved. Government was able to offer such salary increments because of the savings of approximately ten billion Uganda shillings (UShs) saved as a result of retrenchment of group employees and the cleaning up of the payroll. ${ }^{390}$ In spite of such efforts, the salary levels remained very low and far from the recommended MLW. Langseth and Mugaju (1996) lamented that "after these salary increases, Uganda's wage bill was still only 1.2 percent of GDP - one of the lowest wage bills in Africa." ${ }^{391}$ During the period from 1990 to 1994 the national economy was steadily recovering with a growth rate of $10 \%$ per annum. Based on the revenue projections and further reductions in the size of the CS workforce, it was anticipated that the MLW would be attainable by July 1996. The anticipation was also based on the assumption that monetization of benefits and consolidation of all allowances would be incorporated into the wage bill. Table 6.8 below illustrates the projected take home salary for the lowest salary scale level from 1993 to 1996 when the MLW would be offered. The salary is predicated on the continued reduction of the number of CS workers. In 1996, the US dollar/Uganda shilling exchange

\footnotetext{
${ }^{389}$ Interview with the Director of Administrative Reform Secretariat, Ministry of Public Service, held July $21,2006$.

${ }^{390}$ Government of Uganda, Ministry of Public Service. 1994. Management of Change: Context, Vision, Objectives, Strategy and Plan. Kampala, Uganda.

${ }^{391}$ Langseth, P. and Justus Mugaju, 1996. Post-Conflict Uganda: Towards an Effective Civil Service. Kampala: Fountain Publishers, p. 73.
} 
rate was 1 to 1,000 , hence the junior officer would earn 70 dollars per month. The compression suggested was 10:1 and so the highest paid officer (U1) would earn 700 dollars per month (700,000 Uganda Shillings).

Table 6. 8 Projected Minimum Living Wage (Uganda Shillings)

\begin{tabular}{|l|c|c|c|c|c|}
\hline & Apr - 93 & July - 93 & July - 94 & July - 95 & July - 96 \\
\hline Minimum Wage & 19,000 & 27,000 & 45,000 & 60,000 & 70,000 \\
(Scale U7) Monthly & Ushs & Ushs & Ushs & Ushs & Ushs \\
\hline & 65 & 89 & 120 & 150 & 180 \\
Wage Bill & Billion & Billion & Billion & Billion & Billion \\
(Annual) & Ushs & Ushs & Ushs & Ushs & Ushs \\
\hline Staff in the & & & & & \\
Civil Service & 218,141 & 214,943 & 145,000 & 145,000 & 145,000 \\
\hline
\end{tabular}

Source: Government of Uganda, Ministry of Public Service, Personnel Monitoring Unit (PMU) in Ministry of Public Service. 1994. Management of Change: Context, Vision, Objectives, Strategy and Plan. Kampala, Uganda, p. 36.

In reality however, by 1996, salary did not increase as planned. While considerable pay increases were enjoyed by all civil servants and the MLW target was attained, those in the higher echelons of the civil service hierarchy benefitted the most. The junior officer at U8 received at 930 percentage salary increase by 1997, but the permanent secretary at U1 enjoyed a far higher 4,246\% increase in his/her salary. With this increase, the compression ration was approximately $22: 1$ pointing to the fact that although sweeping salary increases were advocated, an egalitarian pay structure was not yet attained and employees with scarce skills, especially in the middle level grades, were not getting the pay they deserved. Moreover, despite continued economic growth, Uganda's wage bill as a percentage of GDP still did not compare favorably with other countries in Sub-Saharan Africa. In 1996, the average wage bill for Sub-Saharan Africa 
was over $6.5 \%$ of GDP whereas the Ugandan wage bill was only $4.9 \%$ of GDP but noticeably, an increase from $1.2 \%$ in 1993. Indeed, the increase is quite remarkable even for the junior officers. Table 6.9 below shows the real salary increases for select categories of civil servants.

Table 6.9 Civil Service Salaries for the Years 1993 and 1997 (select civil servants) in US Dollars Equivalent.

\begin{tabular}{|l|c|c|c|}
\hline CIVIL SERVANT & $\begin{array}{c}\text { MONTHLY PAY } \\
\text { IN 1993 (US\$) }\end{array}$ & $\begin{array}{c}\text { MONTHLY PAY } \\
\text { IN 1997 (US\$) }\end{array}$ & $\begin{array}{c}\text { PERCENTAGE } \\
\text { INCREASE }\end{array}$ \\
\hline Primary Teacher (U7) & 7.41 & 68.90 & 930 \\
\hline Nurse & 7.41 & 87.05 & 1,175 \\
\hline Policeman (UP8) & 6.61 & 66.39 & 1,004 \\
\hline $\begin{array}{l}\text { Permanent } \\
\text { Secretary (U1) }\end{array}$ & 36.51 & $1,550.36$ & 4,246 \\
\hline
\end{tabular}

Source: Government of Uganda, Ministry of Public Service. 2002. Public Service Reform Programme 1997-2002. p. 3.

In their study of public service reform in Uganda and Tanzania, Clarke and Wood (2001) also found that there was a dramatic increase in pay levels in Uganda and they use the teachers' salaries to illustrate their point. "The monthly wage of a primary school teacher rose from US\$3 in 1990 to US\$66 in 1997. ${ }^{392}$ Indeed, all my interviewees agreed that salaries have since the initiation of the CSRP improved. One interviewee from the Ministry of Finance said that;

"Over all, I think salaries have improved.... Salary for me has improved and in fact actually to be frank in the traditional civil service we don't hear, we hear less and less people being desperate. Like the kind of situation that was there when I

\footnotetext{
${ }^{392}$ Clarke, J. and David Wood. 2001. "New Public Management and Development: The Case of Public Service Reform in Uganda and Tanzania." In The internationalization of Public Management: Reinventing the Third World State. McCourt, w. and Martin Minogue (eds), Cheltenham, UK: Edward Elgar, pp. 7172 .
} 
joined the public service in 1990 is not the same as it is today. We have in a way been consistent in increasing pay annually because on average we have been putting in an additional between ten to fifteen billion shillings on an annul basis specifically for pay reform. There is an improvement and from what I see, people are not as desperate. ${ }^{, 393}$

Others voiced similar sentiments. "Salaries are actually being enhanced for all public servants on an annual basis. We have come from far." Another; "Before the reforms, the pay was terribly low now it has been enhanced." An officer from the Ministry of Finance revealed her personal story; "Of course salary has improved. When I joined the ministry as a personnel officer at grade level U4 I was earning 180,000 per month. In five years it has gone up to 660,000 so it has more than tripled and since increments come every financial year then maybe in some time, in ten years we will be getting a good amount of money." ${ }^{394}$ Official documents convey similar views. In the Public Service Reform Strategy 2002-2007, it is asserted that "Although the feeling among public officers is that pay is still very low, the trend shows that there have been progressive efforts every year to increase pay. For Example, in the FY91/92 the minimum pay was Ug. Shs. 7,148 (then equivalent to about US \$8) per month for an office attendant and in the FY01/02 it is Ug. Shs. 70,585 (US\$40) per month. The pay for a Permanent Secretary was Ug. Shs. 39,027 (about US\$45) per month in the FY91/92 and is now Ug. Shs. 1,794,742 (US\$1,020)."395

Yet, in spite of the positive views and appreciation of the pay rise, all my interviewees had a caveat to their pay rise songs of praise. It was revealed that when

\footnotetext{
${ }^{393}$ Interview with Mr. Kenneth Mugamba, Commissioner Budget Policy and Evaluation Dept. MFPED, Held July 17, 06.

${ }^{394}$ Interview with Ms. Muhumuza Susan, Senior Personnel Officer, MFPED. Held July 18, 2006.

${ }^{395}$ Ministry of Public Service. 2002. Public Service Reform Strategy 2002-2007. Kampala, Uganda, p. 7
} 
looked at in terms of quantum, salary has indeed gone up, but when inflation and the general cost of living are factored in, the increases lose value. Indeed the general agreement was that the salary is still not enough to cater for their basic needs. There was also a general view that government is not abiding by the salary targets. It was asserted that the government has on a number of times diverted money for salary to other areas like defense and health. Other scholars have also argued that the pay reform is not meeting its objectives. Langseth and Mugaju (1996) are of the view that pay reform is moving slowly and civil servants are becoming impatient. They argue that "the civil service is getting restless" because reform measures such as retrenchment and ministerial restructuring have not generated savings that should improve pay conditions. From the above discussion, it is apparent that the while great strides have been made, the LW is still elusive for most of the civil servants.

\subsubsection{Elimination of Allowances and Monetization of Non-cash Benefits}

Allowances are commonly offered in many administrative systems depending on the nature of work and the expenses incurred in the course of duty. In the developing countries, they also play a role of supplementing low pay and are in some instances boldly called top-up allowances. In Uganda prior to the CSRP, many civil servants relied on allowances to augment their salaries and relied on government housing to offset costs of living. The multiplicity of allowances created numerous problems among them distortions and inconsistencies in pay, unclear guidelines on eligibility, when to be paid, and lack of uniformity in defining and honoring the pay in different ministries, agencies,

and even parts of the country. When the allowances are as many as 76 , the scope for 
abuse increases. Needless to say, those in the higher levels of the bureaucracy enjoyed most of the benefits and allowances. It was therefore decided that all allowances be consolidated into a single basic pay and all non-cash benefits be monetized.

The elimination of many of the allowances and monetization of non-cash benefits like housing was therefore intended to generate greater transparency and fairness in the pay structure, enhance equity for employees in same pay grades, reduce the possibility of abuse, and give employees opportunity to use their income as they desired. It was also envisaged that consolidation of allowances into basic pay, and monetization of benefits, would help government to better assess how much is spent on individual emoluments.

By the end of 1997, all allowances were consolidated into basic pay. Transport benefits and housing benefits were monetized, and government completely divested itself from providing houses (except for the army, prisons and police), and a consolidated salary package was offered to all civil servants. The consolidation enhanced the takehome salary for approximately $70 \%$ of the civil servants. Those who after consolidation had salaries higher than the minimum living wage level did not get further increases. This was mainly the case with senior civil servants who in prior years benefitted from various allowances. According to one study participant who gave his views in confidence, the monetization of non-cash benefits and elimination of allowances did not create equity. $\mathrm{He}$ asserted that "In my view, monetization advantaged certain grades of staff but disadvantaged others. The evidence is in the compression ratio that rose from 1:20 to almost 1:100. A midlevel officer that previously had government housing now has to find 
a house on market value when the salary is not enough to rent a decent house" ${ }^{396}$ Hence, although elimination of allowances and monetization of benefits are essentially good reforms, the fact that equity and egalitarian concerns were not paid attention to, raises serious concerns. However, pay reform was never intended to generate equity. If anything, the goal was to decompress the salary structure so that professional and technocrats can be better rewarded. The major problem therefore is not decompression, but rather, ensuring that mid-level officers get the necessary pay rises to motivate their stay in the civil service. Currently, salaries for personnel in the higher echelons of the civil service exceed the MLW targets whereas for the ones in the mid-levels they do not. Table 6.10 shows this disparity.

From table 6.10 , it is evident that after consolidation benefits and allowances, personnel in pay levels U5 through U1 did not attain a MLW. There is no doubt that their salaries went up, but their expectations were dashed. It has been acknowledged that "At the senior/middle level of the service, it was found necessary to increase pay to a level approximately $25 \%$ less than the living wage target, in order to meet other demands on the wage bill." 397 The biggest demands were salary increases for primary school teachers and military expenditure. In the period 1997-1999, the effort was shifted to rationalizing the structure in order to make it more transparent and easy to administer. Consequently, a rational basis for grading jobs to determine their relative worth was developed through a job evaluation exercise.

\footnotetext{
${ }^{396}$ Interview Number UG 0018, held August 18, 2006.

${ }^{397}$ Government of Uganda, Ministry of Public Service. 1996. Uganda Civil Service Reform Programme Status Report 9. Kampala, p. 33.
} 
Table 6.10 Consolidated Civil Service Pay (Ug. Shs. gross per month).

\begin{tabular}{|l|c|c|c|}
\hline GRADE & $\begin{array}{c}\text { BASIC PAY } \\
\mathbf{1 9 9 5 / 1 9 9 6} \\
\text { (Ushs) }\end{array}$ & $\begin{array}{c}\text { CONSOLIDATED } \\
\text { PAY 1996/1997 } \\
\text { (Ushs) }\end{array}$ & $\begin{array}{c}\text { MINIMUM LIVING } \\
\text { WAGE TARGET } \\
\text { (Ushs) }\end{array}$ \\
\hline $\begin{array}{l}\text { Permanent } \\
\text { Secretary }\end{array}$ & 162,029 & $1,627,884$ & $1,099,269$ \\
\hline Director & 152,441 & $1,095,197$ & 771,366 \\
\hline U1 & 162,092 & 617,244 & 771,366 \\
\hline U2 & 100,034 & 396,782 & 534,254 \\
\hline U3 & 96,458 & 265,440 & 361,194 \\
\hline U4 & 92,788 & 194,911 & 270,034 \\
\hline U5 & 78,928 & 142,034 & 155,527 \\
\hline U6 & 54,157 & 93,157 & 91,028 \\
\hline U7 & 49,788 & 75,204 & 70,515 \\
\hline U8 & 35,744 & 53,473 & 58,941 \\
\hline $\begin{array}{l}\text { Support } \\
\text { Staff }\end{array}$ & 23,292 & 46,138 & 48,711 \\
\hline
\end{tabular}

Source: Government of Uganda, Ministry of Public Service. Uganda Civil Service Reform Programme Status Repot 9, Kampala, Uganda, p. 34.

\subsubsection{Rationalization of the Pay and Grading System}

To streamline the pay and grading system, the Ministry of Public Service (MPS) undertook a job evaluation exercise. According to the Ministry of Public Service, the objective of the exercise was to "evaluate all jobs defined in the ministerial structures and allocate grades to these jobs, and to develop a new rational salary structure for the civil service taking into account restructuring. ${ }^{, 398}$ The exercise accomplished the following:

- Comparatively graded jobs across the various public service groups on the basis of qualifications, training, knowledge and weight of responsibilities

\footnotetext{
${ }^{398}$ Government of Uganda. Ministry of Public Service. 1996. Uganda Civil Service Reform Programme: Status Report 10. Kampala, p. 18.
} 
- Gauged the disparities in pay among the jobs of the same grade, and

- Objectively indicated what adjustments in pay among the various jobs grades and across staff are needed to ensure fair and transparent compensation for everyone in the service. ${ }^{399}$

The exercise has been hailed as a great effort in rationalizing and removing inconsistencies from the salary structure. One interviewee revealed that "the exercise was important in addressing pay disparity for comparable jobs and selective pay awards." 400 The exercise addressed distortions in what is commonly known as the traditional civil service which includes the ministries, teaching service, the medical staff, police and police and prisons, and culminated in what is known as the "single spine salary structure." The single spine salary structure is one where employees in the same pay grade are paid equally. It was asserted that job grading helped to establish incentives in the salary structure based on the contribution and performance of individuals, and helped to improve equity in pay for employees in the same salary grade.

The evaluation generated salary targets for both the medium term and long term. The medium term (approximately five years) target salaries under the single spine structure ranged from Ug. Shs. 103,000 for support staff grade to Ug. Shs. 2,225,199 for the Head of the Public Service. In the long term "Uganda market" (equivalent to market rates) rates were proposed with target salaries for the lowest and highest grades ranging

\footnotetext{
${ }^{399}$ Government of Uganda, Ministry Of Public Service. 2001. Medium Term Public Service Pay Reform Strategy. Kampala, p. 10

${ }^{400}$ Interview with Ms. Goretti Ssendiyona, Assistant Commissioner, Human Resources Department, Ministry of Public Service, held July 18, 2006.
} 
from Ug. Shs. 282,507 to $2,700,000$ respectively. ${ }^{401}$ Table 6.11 shows the target salaries for select jobs under the single spine structure. For the 2002/2003 financial year, personnel in managerial grades were to get an average salary increase of 18-23 percent. The transition to target pay levels over the years was to be accomplished by allocating the resources available for pay reform each year according to the shortfall between target pay and actual pay for each job grade.

In determining priorities for year to year increases, focus was to be placed on those jobs particularly in managerial/professional grades, where motivation and retention problems severely inhibit civil service performance. However, the low level workers were not ignored. Rather, it was envisaged that low level salary grades that have glaring gaps between the current pay and the job evaluation grade pay would be rationalized accordingly. All these changes were considered under the assumption that funds would be forthcoming from the Ministry of Finance.

If the approved changes in the table above were effected, civil servants would have benefited from a fairly generous remuneration boost. The reality of the implementation of the strategy however proved to be quite different from the aspirations. It has been reported that "The 2002 Strategy has achieved significant, but insufficient progress in enhancing pay levels for middle level professionals and managers." 402

\footnotetext{
${ }^{401}$ Government of Uganda, Ministry of Public Service. 2002. Public Service Reform Strategy 2002-2007. Kampala, p. 32.

${ }^{402}$ Government of Uganda, Ministry of Public Service. 2005. An Update of the Public Service Pay Reform Strategy. Kampala, Uganda, p. 3
} 
Table 6.11 Illustration of the Civil Service Median Pay, Job Evaluation Median Pay, and Market Median Pay Levels

\begin{tabular}{|c|c|c|c|c|c|}
\hline $\begin{array}{l}\text { BENCHMARK } \\
\text { JOB }\end{array}$ & $\begin{array}{c}\text { CIVIL } \\
\text { SERVICE } \\
\text { MEDIAN } \\
2001 / 2002 \\
\text { (UShs) }\end{array}$ & $\begin{array}{c}\text { JE } \\
\text { MEDIAN } \\
\text { SINGLE } \\
\text { SPINE } \\
\text { (UShs) }\end{array}$ & $\begin{array}{c}\text { DIFFERENCE } \\
\text { BETWEEN JE } \\
\text { AND } \\
\text { PS MEDIAN } \\
\text { 2001/2002(Ushs) }\end{array}$ & $\begin{array}{c}\text { MARKET } \\
\text { MEDIAN } \\
\text { (UShs) }\end{array}$ & $\begin{array}{c}\text { DIFFERENCE } \\
\text { BETWEEN MKT } \\
\text { AND } \\
\text { PS MEDIAN } \\
\text { (UShs) }\end{array}$ \\
\hline Managing Director & $1,794,740$ & $1,816,152$ & 21,412 & $2,700,888$ & 906,148 \\
\hline Personnel Manager & 925,130 & $1,462,387$ & 537,257 & $1,787,812$ & 862,682 \\
\hline Medical Doctor & 541,300 & 715,842 & 174,542 & 941,808 & 400,508 \\
\hline Lawyer & 530,250 & 560,112 & 29,862 & 991,397 & 461,147 \\
\hline $\begin{array}{l}\text { Senior Personal } \\
\text { Secretary }\end{array}$ & 371,850 & 391,787 & 19,937 & 581,033 & 209,183 \\
\hline Engineer & 370,040 & 560,112 & 190,072 & 851,689 & 481,649 \\
\hline Graduate Teacher & 370,040 & 560,112 & 190,072 & 397,084 & 27,044 \\
\hline Accountant & 370,040 & 560,112 & 190,072 & 721,246 & 351,206 \\
\hline Auditor & 370,040 & 560,112 & 190,072 & 741,382 & 371,342 \\
\hline Economist & 370,040 & 560,112 & 190,072 & 756,932 & 386,892 \\
\hline Systems Analyst & 279,500 & 560,112 & 280,612 & $1,056,121$ & 776,621 \\
\hline Clinical Officer & 275,580 & 391,787 & 116,207 & 392,625 & 117,045 \\
\hline Registered Nurse & 212,100 & 391,787 & 179,687 & 300,473 & 88,373 \\
\hline Teacher Grade 5 & 156,150 & 281,400 & 125,250 & 202,500 & 46,350 \\
\hline Accounts Assistant & 125,580 & 188,150 & 62,570 & 376,266 & 250,686 \\
\hline $\begin{array}{l}\text { Engineering } \\
\text { Assistant }\end{array}$ & 125,580 & 188,150 & 62,570 & 452,932 & 327,352 \\
\hline Teacher Grade 3 & 101,090 & 188,150 & 87,060 & 157,000 & 55,910 \\
\hline Driver & 65,345 & 139,942 & 74,597 & 282,507 & 217,162 \\
\hline
\end{tabular}

Source: Government of Uganda, MPS Payroll Monitoring Unit. In Public Service Reform Strategy 20022007, Ministry of Public Service. 2002 Kampala, p. 33.

Indeed only one pay grade met the strategy pay guide - U8. This is the lowest pay grades comprising of support staff. Table 6.12 below shows the target salary levels for 2003 and the actual pay. Table 6.12 shows that pay levels were higher in the 2003/04 financial year than those in the 2001/02 year. Nearly all grades got an increase except U1SE and U1E (Permanent Secretaries and their Deputies). It can therefore be said that progress was made. However, pay levels set by the pay strategy were not met. Indeed in 2004 , the reform is behind its target by between 3\% and $35 \%$. According to my respondents, they were still not met in 2006. 
Table 6.12 Performance of Pay Reform Strategy on Public Service Salary based on the Median Monthly Salary in Uganda Shillings

\begin{tabular}{|l|c|c|c|c|c|c|}
\hline GRADE & PLAN & PLAN & ACTUAL & SHORTFALL \\
YEAR 1 & YEAR 3 & $\mathbf{2 0 0 3 / 0 4}$ & Vs PLAN \\
$\mathbf{2 0 0 1 / 0 2}$ & $\mathbf{2 0 0 3 / 0 4}$ & & \% \\
(Ushs) & (Ushs) & (Ushs) & (Ushs) & \% TO REACH \\
THARGET \\
U1S & $1,965,707$ & $2,125,182$ & $1,965,760$ & 159,422 & 8 & 27 \\
\hline U1SE & $1,928,804$ & $2,025,244$ & $1,313,000$ & 712,244 & 35 & 49 \\
\hline U1E & $1,142,175$ & $1,294,466$ & $1,039,043$ & 255,423 & 20 & 45 \\
\hline U2 & 709,701 & 878,677 & 841,855 & 36,822 & 4 & 41 \\
\hline U3 & 557,118 & 689,765 & 650,675 & 39,090 & 6 & 42 \\
\hline U4 & 398,623 & 493,533 & 480,880 & 12,653 & 3 & 40 \\
\hline U5 & 233,707 & 289,352 & 252,160 & 37,192 & 13 & 47 \\
\hline U6 & 164,029 & 203,084 & 188,365 & 14,719 & 7 & 43 \\
\hline U7 & 122,707 & 151,923 & 113,565 & 38,358 & 25 & 54 \\
\hline U8 & 72,242 & 80,498 & 85,616 & $-5,118$ & -6 & 38 \\
\hline
\end{tabular}

Source: Government of Uganda, The law and Development Partnership Limited. 2004. "A Study on Remuneration and Pay Policies for Public Service Institutions and Government Agencies.” Kampala, p. 27.

The Assistant Commissioner Human Resources in the MPS noted that "the salary targets set by the job evaluation exercise have not been achieved to date."403

Participants decried the lack of government commitment to abide by the pay strategy. They asserted that they believe government no longer considers pay increase a priority. It was argued that government is quick to increase employment in some sectors like education and health without adequate planning for impacts on salary. Some laid the blame on the government's Medium Term Expenditure Framework (MTEF). It was asserted that the MTEF does not provide for adequate growth in the wage bill in comparison to other programs like defense. In addition, participants revealed that it has been difficult to abide by the single spine pay strategy because government had

\footnotetext{
${ }^{403}$ Interview with Ms. Goretti Ssendiyona, Assistant Commissioner, Human Resources Department, Ministry of Public Service. Held July 18, 2006.
} 
increasing resorted to non-institutionalized award of salary increases to certain segments of civil servants like judges, doctors and teachers. There therefore general consensus that in spite of the progress made, the rationalization and pay and the job grading exercises had not attained their goals. Ultimately, pay reform has stalled and failed to meet set targets.

\subsubsection{The Politics of Pay Reform in Uganda}

The first few years of the CSRP witnessed tremendous progress in both size reduction and pay increase because there was consensus between the bureaucratic leaders, government leaders, and especially the president, that the civil service crisis needed to be addressed. To motivate workers, encourage better performance, and curb corruption, pay reform was embraced by the government leadership. When the crisis eased, pay reform was relegated to a low priority by the political leadership. A number of reasons account for the shift in priorities. Politically, the country was witnessing an aggressive military insurgence in the northern part of the country that necessitated the president to refocus his attention in the military. It was not uncommon for resources budgeted for salary enhancement to be allocated to military force. For instance in the 1999/2000 financial year, "18 billion Uganda shillings was diverted from salaries to the military to combat the insurgence. In addition, the economy slumped during the same period. ${ }^{404}$

\footnotetext{
${ }^{404}$ Interview Number UG0018, held August 18, 2006.
} 
Public administration structures have been on the increase in Uganda since 1996. Numerous autonomous and semiautonomous agencies have been created and a number of districts have also been created (section 6.2). The introduction of UPE in 1996 also led to an increase in primary school teachers. All of the above increases have had an impact on the civil service wage bill. The creation of agencies has been on the rise in numerous administrative reform programs in both developed and developing countries because it is believed independent agencies perform better, generate revenue, and the autonomy they enjoy fosters innovativeness.

In Uganda, while some agencies have indeed improved performance and revenue generation for instance the Uganda Investment Authority (UIA) and Uganda Revenue Authority (URA), many have not done so. More over, even those doing well are riddled with internal managerial problems and corruption claims. ${ }^{405}$ With regard to pay reform, it has been argued that agencies were created "without a clear link to mainstream traditional civil service pay terms and conditions of service. ${ }^{, 406}$ Generally agencies are supposed to raise their own funds through user fees like sale of permits, and pay better salaries based on the funds raised, but according to one study participant, some agencies depend nearly completely on the government consolidated fund. "The problem is that there are quite a

\footnotetext{
${ }^{405}$ see for instance Odd-Helge Fjeldstad,. 2005. "Corruption in Tax Administration: Lessons from Institutional Reforms in Uganda." CMI Working Papers.

${ }^{406}$ Government of Uganda, Ministry of Public Service, 2005. An Update of the Public Service Pay Reform Strategy, Kampala, p. 17.
} 
number of agencies that still depend on government consolidated fund but they are paying better so they actually bring distortions in terms of public service pay reform." ${ }^{, 407}$ It was argued that since some agencies draw salaries from the consolidate fund, unless they are able to demonstrate the value they are adding, they should not get the money to offer better salaries.

Indeed, considerable disparity exists between the traditional civil service and the public autonomous agencies and such disparities are widest at the low pay grades with the traditional civil service paying significantly less. In a study on remuneration and pay policies for public service institutions and government agencies in Uganda commissioned by the MPS, it was found that "at the lowest end of the pay scale, i.e., at U8, the minimum salary offered with in the Service represents only $15 \%$ of that offered by the highest payer, to the same category of employee. The gap is narrowest at Permanent Secretary or Heads of Organization level, where the lowest pay stands at $25 \%$ of the highest on offer within this category." ${ }^{\text {408 }}$ Table 6.13 below illustrates the disparity in pay levels between the traditional public service and government agencies.

It is evident that some government agencies pay significantly higher salaries than the traditional civil service (Table 6.13). A Permanent Secretary in a Ministry earns more than three times less than the highest paid Head of Government Agency - 2,731,760 and $8,596,100$, respectively.

\footnotetext{
${ }^{407}$ Interview with Mr. Kenneth Mugamba, Commissioner Budget Policy and Evaluation, Ministry of Finance, held July 17, 2006.

${ }^{408}$ Government of Uganda, The law and Development Partnership Limited. 2004. "A Study on Remuneration and Pay Policies for Public Service Institutions and Government Agencies." Kampala, p. 16.
} 
Table 6.13 Pay Disparity within the Public Service (Gross Pay)

\begin{tabular}{|c|c|c|c|c|c|c|}
\hline GRADE & POSITION & $\begin{array}{l}\text { TYPICAL } \\
\text { TITLE }\end{array}$ & $\begin{array}{l}\text { TRADITIONAL } \\
\text { PUBLIC } \\
\text { SERVICE (Ushs) }\end{array}$ & $\begin{array}{l}\text { MINIMUM } \\
\text { (Ushs) }\end{array}$ & $\begin{array}{c}\text { MEDIAN } \\
\text { (Ushs) }\end{array}$ & $\begin{array}{l}\text { MAXIMUM } \\
\text { (Ushs) }\end{array}$ \\
\hline U1S & $\begin{array}{c}\text { Permanent } \\
\text { Secretary }\end{array}$ & $\begin{array}{c}\text { Heads of } \\
\text { Organizations }\end{array}$ & $2,731,760$ & $2,200,000$ & $3,797,680$ & $8,596,100$ \\
\hline U1SE & Directors & $\begin{array}{c}\text { Heads of } \\
\text { Functions } \\
\text { Deputy MDs } \\
\end{array}$ & $1,879,000$ & $1,320,000$ & $2,241,468$ & $7,000,000$ \\
\hline $\mathrm{U} 1 \mathrm{E}$ & Commissioners & $\begin{array}{c}\text { Heads of } \\
\text { Departments } \\
\end{array}$ & $1,230,043$ & $1,020,000$ & $1,939,985$ & $5,112,500$ \\
\hline $\mathrm{U} 2$ & $\begin{array}{c}\text { Principal } \\
\text { Officers }\end{array}$ & Heads of Sections & $1,032,855$ & 688,242 & $1,405,000$ & $3,131,120$ \\
\hline U3 & Senior Officers & $\begin{array}{c}\text { Assistant } \\
\text { Managers } \\
\end{array}$ & 841,675 & 555,946 & $1,200,000$ & $2,487,475$ \\
\hline U4 & Officers & Officers & 579,880 & 401,201 & 874,436 & $1,984,117$ \\
\hline U5 & $\begin{array}{l}\text { Technicians/ } \\
\text { Supervisors } \\
\end{array}$ & $\begin{array}{l}\text { Technicians/ } \\
\text { Supervisors }\end{array}$ & 351,160 & 238,694 & 685,000 & $1,465,367$ \\
\hline U6 & $\begin{array}{l}\text { Senior Clerks/ } \\
\text { Senior Nurses }\end{array}$ & $\begin{array}{c}\text { Senior Clerks/ } \\
\text { Secretaries }\end{array}$ & 287,365 & 205,078 & 562,051 & $1,159,070$ \\
\hline U7 & $\begin{array}{c}\text { Clerks, Nurses, } \\
\text { Teachers, and } \\
\text { Police Officers }\end{array}$ & $\begin{array}{l}\text { Clerks, Typist } \\
\text { Receptionist }\end{array}$ & 212,565 & 184,185 & 398,675 & 944,541 \\
\hline U8 & $\begin{array}{c}\text { Cleaners and } \\
\text { Drivers } \\
\end{array}$ & $\begin{array}{c}\text { Cleaners and } \\
\text { Drivers } \\
\end{array}$ & 184,615 & 112,500 & 317,506 & 736,596 \\
\hline
\end{tabular}

Source: Government of Uganda, The law and Development Partnership Limited. 2004. "A Study on Remuneration and Pay Policies for Public Service Institutions and Government Agencies.” Kampala. p. 16.

The incredibly large disparity in pay levels reinforces demands for unaffordable pay increases within the traditional public service and greatly inhibits motivation among the staff. In reality, there may be only a few people in the government agencies that earn such a higher salary, but that does not deter civil servants from using the highest pay for a specific job category as an indicator for "the appropriate" pay for that category in the traditional civil service. In their view, the gap between the top pay and their own is evidence of their underpayment. One officer that spoke to me in confidence said that; 
"If government is committed to paying public servants what they deserve, then a market-based single spine salary structure has to be implemented and abided by. You see these agencies pay market level salaries yet they depend on government funds to do so. So why should their workers earn more than us? In my view compulsory pay limits linked to the traditional public service pay structure should be set for these agencies. If any discrepancy is to pertain, then the salaries should reflect the ability of the agency to be self-financing such that the greater the extent to which they are capable of generating their own revenues, the more the freedom to set their pay levels. ${ }^{409}$

The gradual increase in the size of government has therefore had significant implications for pay reform. While the increasing the number of primary school teachers has increased the traditional civil service wage bill, the teachers' wage bill is very minimal compared to what autonomous agencies pay their staff. It can therefore be said that the creation of districts and autonomous agencies, and the increasing number of teachers have all had the effect of exerting more expenditure pressure on government to the detriment of salary enhancement. There is need to rationalize the number and functions of agencies and districts while guaranteeing their functionality so that due attention is paid to abiding by the recommendations of the pay reform strategy.

Ultimately, the increase in the size of the service is largely at the expense of increased pay. At stake therefore is how to deal with annual recruitment, salary enhancement and maintaining a balanced budget. There are those who are skeptical about that happening soon. Robinson (2006) asserts that "the slowing down of progress in pay reforms and the untrammeled growth in the political bureaucracy since the late 1990s is the product of a deliberate political strategy. Many of the appointees to statutory and ad hoc commissions and autonomous agencies are known supporters of the Movement with

\footnotetext{
${ }^{409}$ Interview Number UG 0018, held August 18, 2006.
} 
strong kinship ties to the president's family, and were placed in positions of authority with approval at the highest level. Such positions can thus be considered as sinecures for loyal followers, as a form of patronage dispensed in return for political support."410

Another major reason why pay reform has faltered is because of the inadequate wage bill releases from government. The financial resources for implementing the pay reform strategy have been declining while civil service numbers have been rising. In the 2002/2003 financial year, 17 billion Uganda shillings was availed. This is because effort was made to abide by the job evaluation pay strategy recommendations. Between the years 2003 through 2005 however, in spite of continued growth in staff numbers, the amount stagnated at 15 billion as presented in the table below.

Table 6.14 Pay Reform Wage Bill provision for the Period 2001/02 - 2005/06 (Billion Uganda Shillings)

\begin{tabular}{|l|c|c|c|c|c|}
\hline & $\mathbf{2 0 0 1} / \mathbf{0 2}$ & $\mathbf{2 0 0 2 / 0 3}$ & $\mathbf{2 0 0 3 / 0 4}$ & $\mathbf{2 0 0 4 / 0 5}$ & $\mathbf{2 0 0 5} / \mathbf{0 6}$ \\
\hline $\begin{array}{l}\text { Pay Enhancement } \\
\text { (Reform) Wage Bill }\end{array}$ & 15.6 & 17.0 & 15.0 & 15.0 & 15.0 \\
\hline
\end{tabular}

Source: Government of Uganda, Ministry of Finance, Planning and Economic Development.

The pay target levels set by the pay reform strategy are still a long way from being attained. If the issue of salary is not rectified, it will be difficult to recruit and retain adequate numbers of technical and professional workers. Trained professionals with essential skills are needed to advance public service. The Uganda government persistently claims that revenues are limited; overall government expenditures are on the increase, and therefore adequate resources to implement the living wage are scarce. Yet,

${ }^{410}$ Robinson, M. 2006, Ibid, p. 19. 
resources seem to be always available for military expenditure. In the 2000-2004 Uganda was involved in military altercation with the Democratic Republic of Congo at a very high financial cost. It therefore seems apparent that political priorities constitute a superseding factor in government allocation of resources and in determining the whether pay targets will be honored.

As the pay strategy flounders and the workers get restless about not getting a living wage, ministries have found themselves looking for ways and means of motivating their workers, alternatives that in reality work against the reform process. It is therefore not surprising that there has been recourse to non-salary benefits. Non-salary benefits cloud the actual remuneration levels and works against all the effort that was expended in consolidating benefits into one single salary. Some of the common allowances have mushroomed back into the public service include lunch allowance, entitlements, compassion benefits and honoraria. Lunch allowance in 2006 was four thousand shillings per day for officers in the grades U1-U7 (approximately 2.5 US dollars). The support staff those at U8 were paid three thousand Uganda shillings (approximately 1.8 US dollars). Lunch allowance is not an entitlement and hence cannot be claimed in arrears when not paid on time. Entitlements, generally enjoyed by political appointees and entitled officers include telephone allowances, fuel allowance, and entertainment allowance among others. These allowances can be claimed in arrears when funds are not released on time. Compassionate allowances are those funds given discretionally to officers to deal with personal needs like death in the family or illness, and honoraria is given to those workers that spend time beyond working hours on official duty. 
Allowances negate the goals of the pay reform strategy and work against equity, transparency, and sustainability. Allowances may prop up the salaries of workers hence motivate them but the workers that are not receiving them will be demoralized. According to MPS, this trend has created competition in the allocation of resources to either the wage bill or non-salary allowances. Since allowances benefit only a few people and no tax is paid against them, the resources would be better used in augmenting salaries which are taxed. It is been asserted on the other hand that "while allowances and nonsalary benefits introduce degrees of opaqueness and inequities, and may encourage tax avoidance, they may be preferred to salary increases in the short term due to pension constraint. ${ }^{, 411}$

No issue illustrates the politics of pay reform in Uganda as much as selective pay. When it became evident that progress towards the living wage had stalled, various professional groups started agitating for higher pay and threatened to "down" their tools. Among these groups are the judicial officers, the medical doctors, and university lecturers. Soon evening and night meetings were being held between the group's representatives and the president, and before long, higher pay award promises were being made. In 2005, the MPS complained that "Recent intervention by H.E the President in support of select salary enhancement for health workers epitomizes the potential and

\footnotetext{
${ }^{411}$ Government of Uganda, Ministry of Public Service. 2005. An Update of the Public Service Pay Reform Strategy. Kampala, p. 19
} 
significance of political interventions in pay policies implementation.. ${ }^{412}$ In the report of the pay reform update, the MPS asserts that;

"This selective pay award for health workers has contradicted the prevailing pay reform strategy in four particularly significant respects. First, it reintroduces the disparities and inequities in pay that the JE and "single spine salary structure" implementation had targeted to remove. Secondly, the public service pay level considerably exceeds that of most employees in the same grades in the NGO health sub-sector, which account for at least $30 \%$ service delivery in the sector. Thirdly, implementation of the selective pay award for health workers implied an annual increase of Ushs 38.6 billion (or some 5\%) in the annual Government wage bill just for one sector. Fourthly, other public sector groups including teachers and university staff have started agitating for Presidential pay award. This situation could result in spiral of selective salary awards and may not be politically tenable. The end result would be a reversal of most of the pay strategy reform gains." ${ }^{413}$

Indeed, university lecturers have gone on strikes numerous times; in 1989, 1994, and as recently as 2005 . In all instances, the government gave the lecturers an ultimatum and ordered them back to the lecture rooms or to vacate university premises, but in the end, it was the government that capitulated and negotiated pay increases. Their salaries have significantly increased although they have not reached the LW level and they do not compare favorably with those of the workers in the autonomous agencies.

Many of the study participants perceived selective pay to be unfair and arbitrary. The Assistant Commissioner, Human Resources in the MPS revealed that selective pay awards persist and present a big challenge to pay reform. "Here at the ministry we did all work and came up with a single spine salary structure for all civil servants but politics is

\footnotetext{
${ }^{412}$ Government of Uganda, Ministry of Public Service. 2005. An Update of the Public Service Pay Reform Strategy. Kampala, p. 19

${ }^{413}$ Government of Uganda, Ministry of Public Service. 2005.Ibid, p. 21.
} 
undermining it. Contrary to our suggestions, you find doctors, lawyers and university professors being politically awarded selective pay increases." ${ }^{, 414}$

Another participant observed that;

"We have had problems with the political directives saying you give the doctors, and now when you give those the others are somehow disadvantaged. When the president gives directives increasing salaries of specific career groups, it upsets the pay strategy we had set. This is one of the most challenging things under the pay reform." 415

Indeed the pay strategy that emerged from the job evaluation exercise recommended a single spine structure which if abided by, would have ensured that the pay targets for all civil servants are met. This would have taken place over a long time frame approximately ten years - but it would have ensured consistency and equity in pay raises. However, politics have been infused in the pay process rendering pay reform a failure. This is one of the major differences between Uganda's program and Tanzania's as shall be seen in the chapters ahead.

\subsubsection{Improving Remuneration in the Uganda CS: Rhetoric or Reality?}

The analysis in this chapter has illustrated how challenging pay reform in the Uganda CSRP has been. Pay reform as advocated by the PSRRC was intricate and elaborate. The reform process set out to enhance pay for all civil servants and at the outset impressive increases were offered across board. Further, salary decompression was

\footnotetext{
${ }^{414}$ Interview with Ms. Goretti Ssendiyona, Assistant Commissioner, Human Resources Department, Ministry of Public Service. Held July 18, 2006.

415 Interview with Director Administrative Reform, Ministry of Public Service, Ms. Deborah Katuramu, held July 21, 2006.
} 
attained, and allowances and benefits were monetized. In addition, a job grading and evaluation exercise was undertaken rationalize the pay structure. It is generally accepted that proper remuneration is essential for the attraction, retention, and motivation of qualified personnel in the civil service, but the mechanisms of attaining it have been derailed by the many factors discussed above.

It has been shown that there is a general view that despite the progress made, pay is still very low. The general view is that when at the start of the reform pay increase was viewed as an urgent matter - the need to enhance performance, reduce corruption, and attract skilled workers could not be denied. However, when the crisis eased, government priorities veered a way from pay reform. The wars in the northern and western parts of the country took precedence as did the war in Congo. The creation of more districts, the increase of employees in social sectors like education and health, and the increase in the 'shadow government' have all contributed to the strain on the government budget which has in turn adversely affected pay reform. Most important though, is the effect of political interference. Presidential directives have interfered with the pay strategy and made it difficult for the MPS and MOF to abide by the single spine pay structure. It is therefore contended here that in spite of initial progress, pay reform is generally still rhetoric.

The findings here reinforce the study undertaken by Kiragu and Mukandala (2005) who assert that "The post - 1996 period is marked by the abandonment by the Government of generous across-the-board salary increases. Instead, there has been: (a) pay rises for the lower grades of the public service, the so called frontline workers; (b) a 
generous increase for top civil servants, and (c) selective salary increases for those public servants serving in critical areas, including the judiciary and medical services." $" 416$

My study contends that civil service pay will not reach the living wage envisaged by the PSRRC for quite some time and CS will continue to be adversely affected. While enhanced pay is not commensurate with improved performance, it is undeniable that good pay is crucial to sustaining worker morale, motivation and zeal. It is therefore not a stretch to assert that inadequate pay is derailing civil service performance and this in turn, has negative consequences for service delivery. Poor pay and poor civil service performance negate the PEAP vision of enhancing performance and improving service delivery in order to reduce poverty, and produces corruption.

\section{4 CAPACITY BUILDING AND THE UGANDA CSRP}

In the Ugandan civil service, all ministries, departments, local governments, and public agencies have the responsibility to train and develop their staff. Each of them has the obligation to formulate training plans based on need and within the defined guidelines. Yet, in 1990, the PSRRC noted that the existing human resource base was characterized by shortages in technical, professional, and managerial fields, was too weak to perform in the effective reform efforts; and had low productivity levels. It was further noted that the low productivity levels were in part due to inadequate training. The PSRRC pointed out that training was not among the top national priorities and that if any training was undertaken, it was haphazard and not based on need and not guided by a

\footnotetext{
${ }^{416}$ Kiragu, K. and Rwekaza Mukundala. 2005. Politics and Tactics in Public Sector Reforms: The Dynamics of Public Service Pay in Africa. Dar es Salaam:Dar es Salaam University Press Ltd, p. 275.
} 
training policy. The Commission emphasized that if the civil service was to perform better, capacity had to be enhanced. It recommended that professional and technical inservice goal-oriented training be encouraged and enhanced to increase productivity, and advised that such productivity be the determinant of promotional possibilities of individual employees.

\subsubsection{Capacity Building: Training and Infrastructure Development}

The fourth component of the CSRP was capacity building, entailing training and retooling of personnel, and enhancing institutional and structural capacities. According to the Secretary Administrative Reform Commission, "capacity building is the creation of conditions in which technically informed labour can be deployed effectively for increased productivity." It was asserted further that capacity building "is a deliberate attempt to develop the existing pool of technical and managerial manpower by the provision of sound training interventions" $" 417$ that are necessary to meet the challenges of reform and development. As the MPS prepared to effect the recommendations of the PSRRC, it was recognized that the reform process calls for "civil servants with renewed energies, knowledge, skills, and commitment."418 Initial capacity building efforts focused on developing skills necessary to carry out the reform program through sensitization workshops and training. By June 1994, a number of workshops had been held with

\footnotetext{
${ }^{417}$ Wangolo, A. M. 1995. "Uganda Civil Service Reform Programme: Implementation of the Reform Measures and Lessons Learned.” In Langseth, P, Sandile Nogxina, Daan Prinsloo, and Roger Sullivan (eds) Civil Service Reform in Anglophone Africa. Washington D.C.: International Monetary Fund, p. 157.

${ }^{418}$ Ibid.
} 
Ministers and Permanent Secretaries, Heads of Departments and Commissioners, Chairpersons of District Service Committees, Senior Managers Health Personnel, Personnel Officers, Teaching Service Personnel, Accounting Personnel, and all District Education Officers and Headmasters. These workshops were crucial in generating enthusiasm and positive response to the reform program. Immediately after the district review, Action Planning and Implementation Workshops were also organized in the remaining 39 Districts. District officials were offered training necessary to work out district development plans, priorities, objectives, and other programs under a decentralized system of administration.

The Ministry of Public Service developed a training plan to provide skills in information technology, communication, office records management, staff and team performance appraisal, public relations, and results-oriented management By the end of 1993, new computers and other office equipment worth US $\$ 300,000$ were installed in the Ministry, senior staff were trained in records management and systems control, personnel management and information system, and other control systems. ${ }^{419}$

Although great effort was placed on undertaking training of the personnel at the MPS, capacity building in the first phase of the reform program - 1991-1997 fell short of addressing the human resource development needs of the entire civil service. Training in the different ministries remained erratic, underfunded and largely on an ad hoc basis. In 1997, with the initiation of the second phase of the reform program, now called the

\footnotetext{
${ }^{419}$ Langseth, P. 1995. "Civil Service Reform in Uganda: Lessons Learned.” In Langseth, P, Sandile Nogxina, Daan Prinsloo, and Roger Sullivan (eds) Civil Service Reform in Anglophone Africa. Washington D.C.: International Monetary Fund.
} 
Public Service Reform Programme (PSRP) 1997-2002, new emphasis was placed on enhancing the capacity of the human resources of the entire civil service.

To deal effectively with training and career development, the MPS mandated a British international consultancy firm - Crown Agents, to undertake a training needs assessment study of the entire civil service in October 1997. In September 1998, the firm released its findings in a document entitled "Report, Policy and Plan for the Development of Human Resources in the Public Service of Uganda.” The report revealed various issues that hampered training and development and made recommendations about how to best streamline training to make it congruent with the reform efforts. Table 6.15 details situation found during the study (current status) and the proposals that were recommended to re-orient training to make it useful to the reform and growth of the CS.

Many of the issues found to be derailing training efforts identified in the training needs assessment study were espoused by the civil servants I interviewed. The Director of Administrative Reforms in the MPS revealed that "the legitimate goals of training have for a long time been subverted." She added; "Training was perceived by some staff and even their superiors as a means of compensating for poor salaries rather than as an avenue to better ones performance. You see, whenever one went for a training program, they got allowances and in some cases good amounts of money especially on the donor funded training courses." ${ }^{, 420}$

\footnotetext{
${ }^{420}$ Interview with Director Administrative Reform, Ministry of Public Service, Ms. Deborah Katuramu, held July 21, 2006.
} 
Table 6.15 Issues in Training and Recommended Policy Shifts

\begin{tabular}{|c|c|}
\hline CURRENT STATUS & NEW POLICY PROPOSAL \\
\hline $\begin{array}{l}\text { Training provision on an ad hoc } \\
\text { basis }\end{array}$ & $\begin{array}{l}\text { Training provided to meet systematically } \\
\text { identified needs }\end{array}$ \\
\hline $\begin{array}{l}\text { Training to meet individual } \\
\text { wants }\end{array}$ & $\begin{array}{l}\text { Training to meet agreed organizational } \\
\text { performance improvement needs }\end{array}$ \\
\hline $\begin{array}{l}\text { The desired output of most } \\
\text { training has been to provide } \\
\text { qualifications }\end{array}$ & $\begin{array}{l}\text { Training to be provided to improve performance in } \\
\text { the job (even when it is through academic courses) }\end{array}$ \\
\hline $\begin{array}{l}\text { Training is often long-term } \\
\text { (sometimes abroad) }\end{array}$ & $\begin{array}{l}\text { Training more often short or modular and in- } \\
\text { country }\end{array}$ \\
\hline $\begin{array}{l}\text { Training awarded to those } \\
\text { already well trained/qualified }\end{array}$ & $\begin{array}{l}\text { Training awarded only to those most in need of } \\
\text { performance improvement }\end{array}$ \\
\hline $\begin{array}{l}\text { Training has mostly emphasized } \\
\text { theory }\end{array}$ & Emphasis to be on practice and performance \\
\hline $\begin{array}{l}\text { Training provided to isolated } \\
\text { individuals has not changed } \\
\text { procedures and practices back in } \\
\text { the work place }\end{array}$ & $\begin{array}{l}\text { Where possible, training to provided to teams of } \\
\text { people from the same organization, to achieve a } \\
\text { critical mass that can support the application of } \\
\text { learning in the workplace }\end{array}$ \\
\hline $\begin{array}{l}\text { Scholarships have been accepted } \\
\text { even where they do not meet the } \\
\text { needs of the Public Service }\end{array}$ & $\begin{array}{l}\text { Scholarships to be accepted only when they are } \\
\text { clearly relevant to identified needs, and then only } \\
\text { awarded to appropriate staff }\end{array}$ \\
\hline $\begin{array}{l}\text { Training has often been treated, } \\
\text { as a reward or supplement to } \\
\text { salary }\end{array}$ & $\begin{array}{l}\text { Training to be provided only when it is needed to } \\
\text { improve competence and performance }\end{array}$ \\
\hline $\begin{array}{l}\text { Formal training has often been } \\
\text { the first or only option }\end{array}$ & $\begin{array}{l}\text { Managers to be given training in developing } \\
\text { themselves and the staff they supervise, on the job }\end{array}$ \\
\hline $\begin{array}{l}\text { Training function in the public } \\
\text { service lacks co-ordination }\end{array}$ & $\begin{array}{l}\text { Clear division of roles and responsibilities and } \\
\text { regular liaison between Ministries and other organs } \\
\text { responsible for training in the Public Service }\end{array}$ \\
\hline $\begin{array}{l}\text { A few cadres have career } \\
\text { development milestones }\end{array}$ & $\begin{array}{l}\text { Cadre development committees to be formed to set } \\
\text { career milestones for all cadres }\end{array}$ \\
\hline $\begin{array}{l}\text { Emphasis has been put on } \\
\text { knowledge first, then skills }\end{array}$ & $\begin{array}{l}\text { Emphasis to be put on competence (i.e. knowledge, } \\
\text { skills and attitude) required to drive performance } \\
\text { improvements in the workplace }\end{array}$ \\
\hline $\begin{array}{l}\text { Training is often low down } \\
\text { on a Ministry's list of priorities } \\
\text { and therefore is underfunded }\end{array}$ & $\begin{array}{l}\text { Priority for training to be increased and sustained to } \\
\text { ensure continuous 'learning' and development in } \\
\text { the Public Service }\end{array}$ \\
\hline $\begin{array}{l}\text { Training budgets have often } \\
\text { been re-allocated }\end{array}$ & $\begin{array}{l}\text { Training budgets to be protected against re- } \\
\text { allocation }\end{array}$ \\
\hline Training is largely supply driven & Training to be driven by demand/need \\
\hline
\end{tabular}

Source: Government of Uganda. Report, Policy and Plan for the Development of Human Resources in the Public Service of Uganda, p. v. 
Another participant noted;

"Generally we have not been having a training policy, like training was ad hoc, that is, before we got a training policy in place, you found people chasing their own training, was driven by the person not by the department or the need of the ministry. Someone would just see something abroad not bothered whether it is beneficial to you or the ministry, you chase it as long as there is some money on it, you go train, come back and some how it will not be useful to the ministry",421

The training needs assessment study recommended a three year training plan for short courses for junior and middle level staff and some for senior personnel. However because of limited resources, only a handful of courses outside the training plan were offered for only 600 personnel. The courses offered in 1999 include the following: ${ }^{422}$

General Management Skills (Middle Managers)
Introduction to ROM
Project Management Skills
Facilities Management
Internal Consultancy Skills
Developing and Managing Information Systems
Skills Upgrading for Finance Staff
Career Planning, Job Analysis, Performance Appraisal
Organizational Skills for Personal Assistants
Human Resource Development
Induction Course for newly Appointed Permanent Secretaries

From 2000 to 2001, the First Year Training plan was implemented with a grant from the Netherlands Government, and all training was undertaken in Uganda using domestic training institutions. The courses covered include the following:

\footnotetext{
${ }^{421}$ Interview with Ms. Muhumuza Susan, Senior Personnel Officer, Ministry of Finance, held July 18 , 2006.

${ }^{422}$ Government of Uganda, Ministry of Public Service. 1999. Public Service Reform Programme: Report for the Year 1999. Kampala, p. 13.
} 


\begin{tabular}{|l|l|}
\hline Courses Covered in 2000 & Courses Covered in 2001 \\
& -Financial Management for supplies and \\
-Word Processing & stores staff \\
- Information Technology & -Corporate Values for Senior Managers \\
-Statistics and Surveys & -Records Management for Records Staff \\
-Operating a switchboard & -Strategic Leadership for Administrative \\
-Accounts & Officers \\
-Managing the Training Function & -Managing Human Resources for \\
-Policy Formulation and Implementation & -Achieving Results \\
-Managing for Results & \\
\hline
\end{tabular}

In 2002-2003, more training was provided to the civil service staff in Integrated

Financial Management System and Staff Appraisal System. A notable improvement in capacity building was "the introduction of Results Oriented Management (ROM) in 23 Urban Authorities, the National and Regional Referral Hospitals, the Service Commissions and other Constitutional Bodies and; provision of support for the implementation of ROM in the Ministries and Local Governments where it had already been introduced." $" 423$ In addition, "A total of 10, 708 public servants attended training/sensitization workshops on the new Staff Performance Appraisal Instrument, of whom 982 were from Central Ministries/Departments, 5,170 from Local Governments and 4,656 from the Education Sector. 168 Copy Typists also completed the skills upgrading course." ${ }^{424}$ It is only in 2003 that the implementation of the First Year Training Plan was completed.

\footnotetext{
${ }^{423}$ Government of Uganda, Ministry of Public Service. 2003. Public Service Reform Programme: Annual Report for the Financial Year 2002/2003. Kampala, p. iv.

${ }^{424}$ Government of Uganda, Ministry of Public Service. 2003. Public Service Reform Programme: Annual Report for the Financial Year 2002/2003. Kampala, Ibid, p. v.
} 


\subsubsection{The Uganda Public Service Training Policy}

The public service training policy was released in 2006. It provides guidelines for training civil servants and aims at "building and maintaining the Public Service as an efficient, effective, and professionally competent administrative machinery of Government, capable of originating and implementing Government programmes." ${ }^{, 25}$ Its specific objectives include providing a strategy to keep civil servants abreast with current professional knowledge and skills, ensuring that training funds are effectively utilized, to ensure fairness in the management and administration of training opportunities, and instill a learning culture with in the civil service among others. ${ }^{426}$

The policy provides for training committees in each of the above to approve training proposals and to oversee their implementation while ensuring strict adherence to the policy. The policy also requires every Ministry/Department/Local Government to designate one officer as "Training Liaison Officer", to coordinate the implementation of all training decisions. Many of the study participants were aware of the training policy and had positive perceptions about it. It was observed that the training policy provides a practical framework within which all government officials will acquire the necessary competencies to perform their duties with creativity, efficiency, effectiveness, and due diligence. $^{427}$ An officer from the Ministry of Education welcomed the training policy saying that the ministry for a long time did not have a training program. "The big

\footnotetext{
${ }^{425}$ Government of Uganda, Ministry of Public Service. 2006. The Republic of Uganda Public Service Training Policy. Kampala, p. ii.

${ }^{426}$ Ibid, p. 3.

${ }^{427}$ Interview with Ms. Ada Kabalokile, Commisssioner, and Acting Director Human Resources and Capacity Building, held July 19, 2006.
} 
challenge as far as skills development is concerned is that we did not have any skills needs assessment. People sought out training opportunities individually, those motivated to look got more chances, and in some cases those with the right connections also get chances to train. The whole thing was not streamlined. ${ }^{428}$ It was observed that training is currently the preserve of the personnel sections within Ministries a mechanism that ensures that training is undertaken in a systematic and coordinated manner. Therefore, while in the past, a relatively high percentage of staff would be away from duty for prolonged periods, pursuing training in an incoherent manner, the new training policy ensures that all comes to an end. ${ }^{429}$

Capacity building efforts in the Uganda public service reform program have predominantly focused on training personnel to acquire better skills, what one of the participants called "performance improvement courses." ${ }^{\text {430 }}$ A lot of training in information technology was offered to the majority of the public servants. In all the ministries covered by the study, it was revealed that almost all staff are computer literate. Different performance improvement courses have been offered in different ministries. For instance the Ministry of Education has offered training to Boards of Governors, School Management Committees, and school Head Teachers training in Education Planning and Administration, Management, Time Management. The Ministry of Finance

\footnotetext{
${ }^{428}$ Interview with Mr. Godfrey Arnold Dhatemwa, Assistant Commissioner, Planning and Budgeting, Ministry of Education, held July 28, 2006.

${ }^{429}$ Interview with Mr. J.B Ssonko, Principal Personnel Officer, Ministry of Local Government, held August $10,2006$.

${ }^{430}$ Interview with Mr. Paul Bogere, Assistant Commissioner Human Resources and Development, Ministry of Public Service, held July 19, 2006.
} 
has offered training to its personnel in diverse fields including planning, policy analysis, corruption and fraud detection, and integrated financial management system. There was a general perception that training has improved the capacity and performance within the civil service. Participants cited better performance in time management and report writing, in budget formulation and budget accounting, and in the in production of annual performance reports.

The above discussion illustrates that capacity building efforts in the public service reform program have been dominated by training. My study findings confirm views advanced by Cheema (2005) who also illustrates how capacity building efforts have focused on training by asserting that Ugandan public servants have received training in "information technology, communication, office record management, performance appraisal, and result-oriented management." ${ }^{, 431}$ The focus on training lends the reform program to some of the criticisms advanced by scholars like Cohen (1995) who notes that most capacity building efforts are limited to training. He goes further to say that in most developing countries capacity building tends to be synonymous with training, a tendency that ultimately leads to failure to address the various constraints to effective public sector performance in a holistic way. ${ }^{432}$ Yet when the Uganda CSRP is analyzed using Cohen's framework for capacity building, a good number of issues he focuses on appear to have been addressed. Salaries have been improved, organization structures have been

\footnotetext{
${ }^{431}$ Cheema, G. S. 2005. Building Democratic Institutions: Governance Reforms in Developing Countries. Bloomfield, CT: Kumarian Press, p. 158.

432 Cohen, J. M. 1995. "Capacity Building in the Public Sector: A focused Framework for Analysis and Action.” International Review of Administrative Sciences, Vol. 61, No. 3, pp. 407-422.
} 
modified, and training institutions have been upgraded. For instance the Uganda Management Institute which was upgraded from a small institute offering refresher courses and certificates to a full fledged higher education organization offering postgraduate diplomas, and masters degrees. ${ }^{433}$

Nonetheless, it is training that has received the bulk of the capacity enhancement resources and this tendency is not unique to Uganda. In their study of the public service reform in Uganda and Tanzania, Clarke and Wood (2001) found that "efforts to build capacity in Tanzanian and Ugandan civil services focused on conventional methods, including the provision of in-country training in a range of basic skills for middle managers and professionals."434 Similar findings are offered by Honadle and Hannah (1982) in the study of capacity building in Jamaica where they propose an action oriented and organization capacity development intervention rather than mere training ${ }^{435}$; and Grindle and Hilderbrand (1995) who found that opportunities for meaningful work, shared professional norms, teamwork, and promotion based on performance may be better at building capacity rather than training in specific skills. ${ }^{436}$ Healy (2001) also

\footnotetext{
${ }^{433}$ In the 2005/2006 financial year, the Uganda Management Institute conducted training for 144 masters students, 560 post graduate diploma students, 154 diploma participants, 294 certificate participants and 1241 short course participants.

${ }^{434}$ Clarke, J. and David, Wood. 2001. "New Public Management and Development: The Case of Public Service Reform in Tanzania and Uganda.” In McCourt, W. and Martin Minogue (eds) The Internationalization of Public Management: Reinventing the Third World State. Cheltenham, UK: Edward Elgar.

${ }^{435}$ Honadle, G. H. and John P. Hannah. 1982. "Management Performance for Rural Development: Packaged Training or Capacity building" Public Administration and Development, Vol. 2, No. 4, pp. 295307.

${ }^{436}$ Grindle, M. S. and Mary e. Hilderbrand. 1995. "Building Sustainable Capacity in the Public Sector: What Can be Done?" Public Administration and Development, Vol. 15, No. 5, pp. 441-463.
} 
advocates a holistic approach to capacity building ${ }^{437}$ while Wubneh (2003) asserts that capacity building should be multidimensional to include such things like value systems and beliefs, depoliticizing decision making, and a focus on institutional and resource factors. ${ }^{438}$

In spite of its seemingly narrow focus, capacity enhancement in the Uganda CSRP seems to be on the right path and some of the study participants revealed that capacity enhancement has not only focused on skills development but also on retooling and equipment development, and on hiring staff with the necessary skills. They revealed that most offices have the requisite equipment to carry out necessary functions especially computers and vehicles. However, it was also revealed that it is mainly Ministries that have donor sponsored projects that have had their equipment upgraded. Such Ministries include MPS, MOF, MOLG, Ministry of Agriculture, and Ministry of Health. Ministries without any projects like the Ministry of Labor lack modern amenities like computers and internet connection.

It can therefore be argued that currently, to acquire modern tools and equipment, a Ministry has to be proactive and come up with programs that have a retooling component; two, donor facilitation must be available; and three, government funds must be available and released in a timely fashion. The first two points imply that most of the infrastructure capacity development is hinged on donor-funded programs which have a

\footnotetext{
${ }^{437}$ Healy, P. 2001. "Training and Public Sector Reform: An Integrated Approach.” Public Administration and Development, Vol. 21, pp. 309-319.

${ }^{438}$ Wubneh, M. 2003. "Building Capacity in Africa: The Impact of Institutional, Policy and Resource Factors.” Africa Development Bank, Oxford: Blackwell Publishing Ltd, pp. 165-198.
} 
specific life span. In essence, once donor funding terminates, capacity may soon deteriorate and even be lost entirely. Such a predicament calls for mechanisms to institutionalize capacity development to make it sustainable.

One of the major challenges mentioned was the attraction and retention of workers with professional and technical skills. It was observed that efforts to enhance capacity through the hiring of staff who have the necessary skills have faltered mainly because of inadequate pay. However, a project initiated under the auspices of the WB is helping in meeting that need. In 2003, a Capacity and Performance Enhancement Project (CAPEP) was initiated under the World Bank's Poverty Reduction Support Credit (PRSC). The PRSC is for a public sector-wide capacity building intervention to assist programs and approaches geared towards poverty reduction. The major goal of this initiative is to ensure that the civil service has the capacity to support the realization of the PEAP goals. Emphasis is placed on increasing the number and quality of professional staff among other things. According to the Ministry of Finance, the CAPEP "also seeks to foster and reinforce linkages and complementarity between the ongoing public sector reform initiatives, primarily the PSRP, the sector development programs (SDPs) and other reforms embedded in the PEAP and supported by the PRSCs." ${ }^{439}$ CAPEP was aimed at strengthening the implementation of the reforms via the linkages depicted in the figure below. The figure below shows that capacity building is viewed as a critical component of the different reforms and ultimately is a vital prerequisite for the poverty alleviation action plan.

\footnotetext{
${ }^{439}$ Ibid, p. 9.
} 
Figure 6.3 Linkages between CAPEP and Ongoing Public Sector Reform Programs

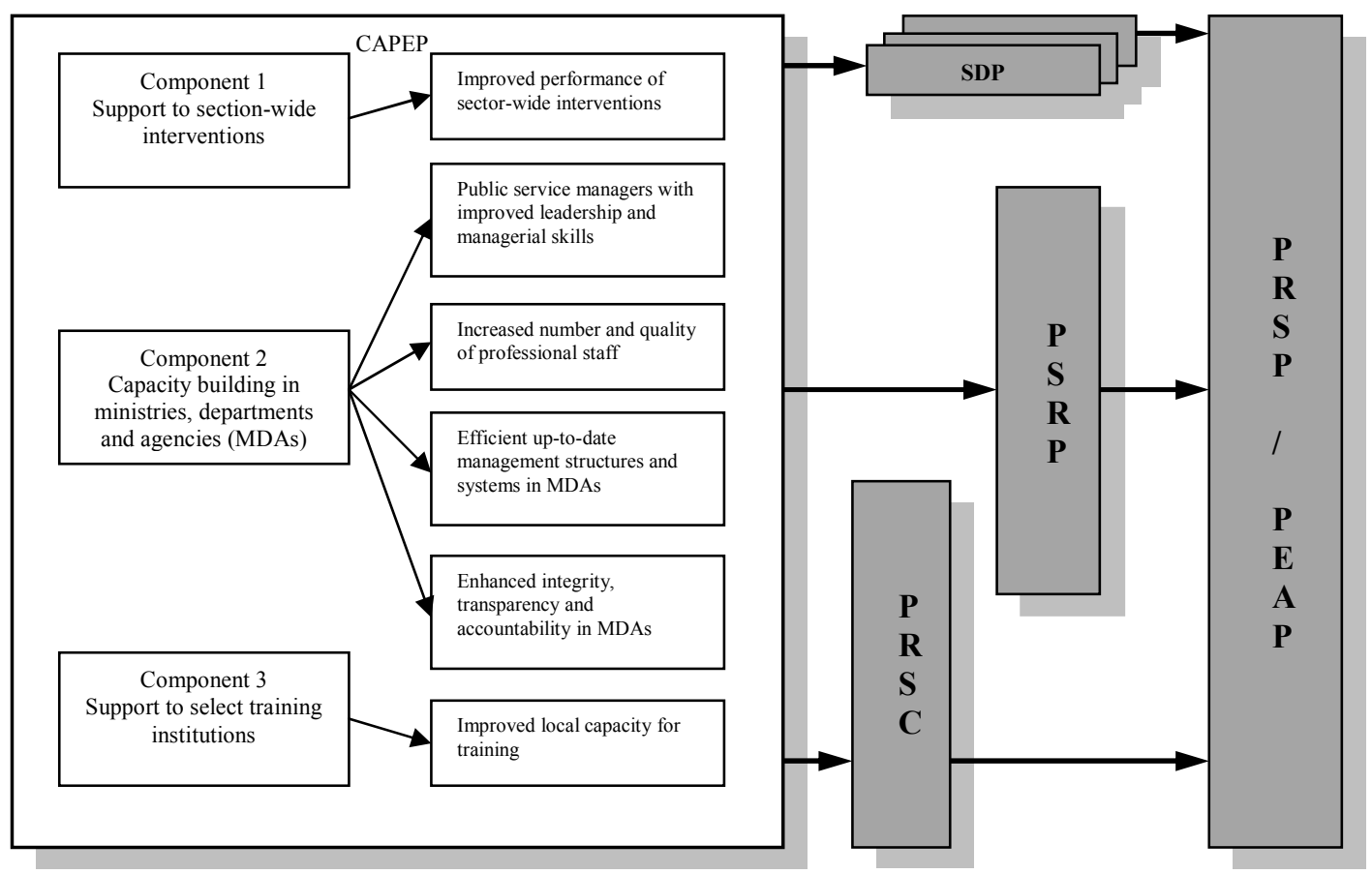

Source: Government of Uganda, Ministry of Finance. 2004. Uganda Capacity and Performance Enhancement Project (CAPEP). Kampala, p. 9

Key: SDP - Sector Development Programs, PRSC - Poverty Reduction Support Credit, PSRP - Public Service Reform Program, PRSP - Poverty Reduction Strategy Paper, PEAP - Poverty Reduction Action Plan.

\subsubsection{Challenges in Capacity Building}

Although great strides have been made to enhance the capacity of the Uganda civil service to effectively undertake the reform process and implement government programs, there are some challenges that the study participants identified as threats to the reform process and effective performance. The major challenge expressed by all participants was limited financial resources. Similar sentiments are evident in the Ministerial annual reports. In the report for financial year 2003/2004, it was revealed that all planned activities under training and staff development were not undertaken. "All planned staff development initiatives under this intervention could not be implemented as 
a result of the lack of resources. Since training enhances the skills of public servants, influences their attitudes and motivates them to perform, it is critical that resources are identified for training and staff development." ${ }^{440}$ Moreover, without adequate financial support, it will remain difficult to attract and retain qualified staff.

In spite of the having the training policy in place, it was found that civil servants still pursue individual training and skill development without regard for the organizational needs. This is because training is still viewed as an avenue to generate extra income. One participant said that "Another problem with training is that people feel that training is a way of either motivation or a way of getting some extra money. So you find some people want to train all the time whether it is relevant or not. When you don't approve it someone gets so angry with you." ${ }^{441}$ Not only do civil servants pursue any available opportunity to train, they seem to be more interested in training out side Uganda. It was observed that most people want to train abroad and not in-house because outside training offers a higher per diem and it is more prestigious. In such instances, training is more about visiting a foreign country than about acquiring new skills. This is what is commonly known as "training tourism." It is anticipated that the newly adopted training policy will rationalize training by striking a balance between time spent on training and on official duty, so that implementation of government programs is not undermined by training.

\footnotetext{
${ }^{440}$ Government of Uganda, Ministry of Public Service. 2004. Public Service Reform Programme: Annual Report for the Financial Year 2003/2004, Kampala, p. 13.

${ }^{441}$ Interview with Ms. Muhumuza Susan, Senior Personnel Officer, Ministry of Finance, held July 18, 2006.
} 
Finally, it can be asserted that much focus has been placed on staff development at the expense of the wider institutional context. Little attention has been paid to the organizational framework, and institutional environment. The latter include the incentive systems, rules and regulations, and accountability. It is contended here that developing skills while ignoring the operational context may negate the goals of reform, and even render the whole process futile.

Yet despite the above criticisms, capacity building efforts in the Uganda CSRP have generated some success. A training needs assessment was undertaken in the entire civil service and the findings helped Ministries to prioritize training opportunities. In general, Ministries attempt to organize training by focusing on the critical areas. Training has been undertaken in important areas like ICT, financial management, and records management to mention a few. In addition, a training policy was developed to guide training. Ministries have training committees and so training is better planned and aligned to Ministerial requirements. It should also be noted that most of the participants were of the view that performance has improved due to the capacity enhancement programs that have been undertaken. It can therefore be asserted that capacity building in the Uganda CSRP has generated considerable success and is becoming a reality.

\subsection{ETHICS AND ACCOUNTABILITY IN THE UGANDA CIVIL SERVICE REFORM PROGRAM}

Ethics and accountability are public service values that many administrative systems strive to integrate in their structures, processes, and systems because they are vital to democratic governance and efficient management of public service systems. In 
many countries, the lack of ethics and accountability manifest themselves in not only abuse of office for self aggrandizement and total disregard for rules and regulations, but also in failed governance at the national level. Such was Uganda's predicament from the 1970s through much of the 1980s.

The PSRRC found that the Ugandan public service was characterized by lack of accountability, embezzlement of public funds, nepotism, favoritism, and other vices that made service delivery impossible. The Commission observed that corruption was rampant and institutionalized. Scholars agree with this assessment for instance Flanary and Watt (1999) assert that "the NRM inherited a public service characterized by wholesale institutionalized corruption., ${ }^{442}$ The Commission recommended that supervisory, inspection and audit systems be strengthened, and that transparency be encouraged by the free flow of information. It advocated more stringent sanction and penalties against the corrupt, suggested that whistleblowers be protected and rewarded, and urged the government to increase remuneration.

In the Uganda civil service reform program long term vision, it is asserted among other issues that the goal of the reform is to create a civil service with "reduced level of corruption backed by an effective police and prosecution function", a civil service where the civil servants will "be fully accountable and responsible for the output of their jobs, and will be committed to achieving clearly identified individual objectives. ${ }^{, 443}$ Ethics and

\footnotetext{
${ }^{442}$ Flanary, R. and David Watt. 1999. "The State of Corruption: A Case Study of Uganda." Third World Quarterly, Vol. 20 No. 3, p. 521.

${ }^{443}$ Ministry of Public Service. 1994. Civil Service Reform: Context, Vision, Objectives, Strategy, and Plan. Kampala, p. 23.
} 
accountability barely manifest in the vision of the civil service reform program in spite of the emphasis accorded the issues by the PSRRC. Indeed the two cannot be categorically found in the major components of the reform program, but they are inherent and implied in some of them. For instance, the Results Oriented Management (ROM) system is viewed as necessary to ensure efficiency, effectiveness, accountability, and responsiveness.

However, neither does the Public Service Reform Programme 1997-2002 nor the Public Service Reform Strategy 2002-2007 specifically mention ethics and accountability. Indeed, one of the study participants confirmed that "The reform program does not directly focus on ethics," ${ }^{444}$ but she hastened to add that nonetheless the reform focuses on areas that can facilitate ethics and integrity. She mentioned ROM, the review of the code of conduct, and implementation of the performance appraisal instrument so as some of the ways ethics and accountability are being addressed. The influence of NPM is evident in the manner in which ethics and accountability are being handled in the Ugandan CSRP. New public management calls for strategic plans with a mission, vision, and measureable outputs. It calls for accountability for the financial resources used, the results achieved, and focuses on customer satisfaction. The following views illustrate;

"To enhance accountability, we are also focusing on clients as a priority so now the focus is on how can we handle our clients better? Client satisfaction has become an issue.... Also the introduction of results oriented management to make sure that we focus on the performance appraisal system. We are looking at

\footnotetext{
${ }^{444}$ Interview with Director Administrative Reform, Ministry of Public Service, Ms. Deborah Katuramu held, July 21, 2006.
} 
outputs. Can you account for what you have done? If you were given money, how have you used it?"445

While the public service reform program does not specifically address ethics and accountability, various government initiatives indicate that the issues were paramount on the government's reform agenda. Since 1986 when the NRM government assumed political power, effort was made to revamp the public service and rid it of the informal systems of behavior that buttressed unethical and corrupt tendencies. Point seven of the NRM Ten-Point Programme asserts that government would focus on "the elimination of corruption and misuse of power."446 Some of the major initiatives geared towards enhancing ethics, integrity and accountability in the public service included the strengthening of preexisting institutions among them the Office of the Auditor General, Directorate of Public Prosecutions, and Public Accounts Committee; the establishment of the Office of the Inspector General of Government, the establishment of the Directorate of Ethics and Integrity; and the encouragement of a free press. All my study participants were aware of the institutional frameworks put in place to enhance ethics and accountability in the public service.

Office of the Auditor General and Public Accounts Committee:

The 1995 Uganda Constitution Article 154 provides for the office of the Auditor General (AG) and Article 163 offers the functions of the office. The AG is responsible for overseeing withdrawals from public funds and auditing government public accounts.

\footnotetext{
${ }^{445}$ Interview with Ms. Monica Kalemba, Under Secretary Finance and Administration, Ministry of Local Government. Held July 25, 2006.

${ }^{446}$ The Ten-Point Programme is a small document detailing the goals that the NRM intended to achieve.
} 
Overseeing withdrawals involves ensuring that all government public funds are secured with parliament's approval and auditing public accounts entails writing a report about all public accounts of all public services and agencies. The report is then submitted to parliament for review by Parliament's Public Accounts Committee. The AG is appointed by the President and can be fired by the latter on grounds of misconduct or incompetence. The Public Accounts Committee (PAC) of the Ugandan Parliament just like the AG is charged with ensuring that all public revenues and expenditures are accounted for. The PAC is supposed to examine and discuss the AG's reports and where necessary order investigations or call for legal proceeding against culprits.

The efficacy of the AG and PAC in enhancing ethics and accountability was cast in doubt by the study participants. It was revealed that the AG for a long time lacked the equipment and human and financial resources to analyze public expenditures and produce reports. As a result, since the AG office was reconstituted in 1986, it has been overwhelmed by the work, and constrained by limited staff and resources. The PAC is experiencing similar problems. It was only after the first Presidential and Parliamentary elections of 1996 (sixth parliament) that a new PAC was instituted and found a huge backlog of reports from the AG's office to scrutinize. It was observed that the PAC was in 2006 reviewing documents submitted in 2003. Moreover, the office does not have the staff and resources commensurate to what needs to be accomplished. A discussion with many of the study participants gave the impression that despite the gains made, they felt that the AG and PAC will not be able to enhance ethics and accountability. Other than lack of personnel and financial resources, it was also revealed that both organs were 
susceptible to political manipulation, interference, and frustration which rendered them ineffective.

Office of the Inspector General of Government:

The establishment of the Office of the Inspector General of Government commonly known as the IGG is one of the most acknowledged achievements of the NRM government's push to enhance ethics, accountability and integrity in public service. An equivalent of the ombudsman, the IGG was established in 1987 and embedded in the 1995 Uganda Constitution (Chapter 13). Article 225 entrust the office with the following functions:

(a) to promote and foster strict adherence to the rule of law and principles of natural justice and administration;

(b) to eliminate and foster the elimination of corruption, abuse of authority and of public offices;

(c) to promote fair, efficient and good governance in public offices;

(d) subject to the provisions of this Constitution, to supervise the enforcement of the Leadership Code of conduct; ${ }^{447}$

(e) to investigate any act, omission, advice, decision/ recommendation by a public officer or any other authority to which this article applies, taken, made, given or done in exercise of administrative functions; and

\footnotetext{
${ }^{447}$ The Leadership Code requires political leaders and public officers to declare their wealth including assets, income, and liabilities. The code prohibits the public officers from engaging in unethical conduct.
} 
(f) to stimulate public awareness about the values of constitutionalism in general and the activities of its office, in particular, through any media and other means it considers appropriate. ${ }^{448}$

Although the IGG is responsible to parliament, he/she is appointed by the president but can only be removed from office by the president on the recommendation of a special parliamentary tribunal. IGGs office deals with a lot of cases among them the following:

- Bribery and extortion

- Mismanagement of public projects and public funds or property

- Neglect of duty

- Causing financial or property loss to the Government

- Making false claims

- Embezzlement

- Abuse of office or authority

- Influence peddling

- Theft or diversion of public funds or assets

- Fraud

- Forgery or uttering false documents

- False accounting

- Conflict of interest

- Victimization

- Delay in public service delivery

- Non-payment of entitlements e.g. salaries, benefits such as pension etc.

- Breach of the Leadership Code ${ }^{449}$

According to one participant, the Inspectorate of Government is one of the institutional mechanisms best placed to enhance accountability in government but like many of the reform efforts, it has not attained the goals it was set out to achieve. He lamented thus;

\footnotetext{
${ }^{448}$ Government of Uganda. 1995. The Uganda Constitution.

${ }^{449}$ Inspectorate of Government. "The Inspectorate of Government and the Fight against Corruption in Uganda" www.igg.go.ug accessed October 3, 2008.
} 
"The IGG was a good innovation but it has not been equipped with the requisite human, financial, technical or physical means to carry out its mandate. It has difficulty in retaining skilled personnel particularly professionals because of noncompetitive emoluments and many of its activities are not carried out due to insufficient funds." ${ }^{, 450}$

Moreover, the IGG lacks the capacity to enforce the leadership code especially if the culprits have high level political connections. The inability of the IGG is affirmed by other scholars. Larbi (2007), in his study of disclosure practices in African public services, found that Uganda's IGG suffered "weaknesses in the institutional and organizational arrangements and frameworks for declaration, monitoring and enforcement." Larbi states that the IGG has met challenges in the bid to enforce the Leadership Code - "in some cases officials have refused to file completely, thus challenging the authority of the IGG." He asserts further that the IGG has a "weak investigative capacity" which undermines capacity to collect ample evidence for prosecution. ${ }^{451}$ Tangri and Mwenda (2006) claim that the IGG has failed to exercise fully "its powers of investigation and prosecution." Flanary and Watt (1999) argue that the problems faced by the IGG are evident in the "apparent impotence when implementing the Leadership Code. $" 452$

In spite of the critical problems the IGG faces, many of the study participants were of the view that the IGG has made tremendous strides in publicizing the importance of ethics in the public service. Most of them mentioned the national integrity survey as a

\footnotetext{
${ }^{450}$ Interview with the Director of Ethics, Directorate of Ethics and Integrity, Mr. Ashaba Aheebwa, held July 27, 2006.

${ }^{451}$ Larbi, G. 2007. "Between Spin and Reality: Examining Disclosure Practices in Three African Countries." Public Administration and Development, Vol. 27, p. 212.

${ }^{452}$ Flanary, R. and David Watt. 1999, Ibid, p. 525.
} 
landmark undertaking that has involved the general public in the discussion of ethics, accountability and integrity. The IGG's office was instrumental in undertaking two major national integrity surveys in 1998 and 2002, and the third one implemented in 2007 is still underway. The surveys generated information based on household and institutional perceptions, and experiences of corruption in the public service. In the 1998 survey, it was found that only $32 \%$ of the household respondents were aware of the work of the IGG but in 2002, the number had increased to $70 \%$. In the 1998 , those identified as the most corrupt government institutions were the police, URA, Magistrate courts, and the local government administrations. The incidence of reported bribes for each of them was $63 \%, 40 \%, 50 \%$ and $39 \%$ respectively. In 2002 , there was significant reduction in the reported incidence of bribery in the same institutions to $46 \%, 31 \%, 29 \%$ and $16 \%$ respectively. The reduction was attributed to the vigilance of the IGG's office and general public awareness and increasing intolerance of corruption. ${ }^{453}$

\section{Directorate of Ethics and Integrity:}

The institutions mentioned previously work in close contact with the Directorate of Ethics and Integrity (DEI). Established in 1998, the Directorate is headed by a Minister of State in the Office of the President and is responsible for the formulation, coordination and the implementation of the national anti-corruption policy. It has the mandate to strengthen ethics, accountability and integrity in all sectors of public life. It is credited with drafting the Leadership Code and putting together the Anti-Corruption Bill that was enacted by Parliament in 2003. The Directorate has been instrumental in undertaking

\footnotetext{
${ }^{453}$ Government of Uganda, Inspectorate of Government. 2003. Final Report: Second National Integrity Survey. Kampla: K2-Consult Uganda Limited, p. 18.
} 
ethics training in Ministries, Agencies and Local Governments. According to the Director of Ethics at the Directorate, "Training of trainers workshops have been organized for government officials, and regional workshops have been held to sensitize District chairpersons, CAOs and District Planner on ethical decision making in the public office. ${ }^{, 454}$ Yet in spite of such efforts, it was revealed that public servants are not keen to attend training on ethics and accountability. It was observed that ethics and accountability are the least demanded training modules in the local governments. ${ }^{455}$

Discussions with various participants revealed that ethics and accountability are still highly elusive in the public service. Indeed, the majority of the study participants were of the view that in spite of the above institutional mechanisms, the area remains a big challenge and one the most difficult to deal with in the public service. ${ }^{456}$ Civil servants are guided by the standing orders of public service but there was a predominant perception that civil servants are not familiar with the code of ethics and conduct. One of the reasons for this state of affairs is because ethics and accountability are not viewed as "major issues." Ethical values like integrity, and accountability, are still looked upon as foreign and a hindrance to rapid personal development. Moreover, the culture that values quick wealth is still widely entrenched. It should also be noted that lack of political will to hold those found guilty of corruption accountable has made it difficult to

\footnotetext{
${ }^{454}$ Interview with the Director of Ethics, Directorate of Ethics and Integrity, Mr. Ashaba Aheebwa, held July 27, 2006.

${ }^{455}$ Interview with Ms. Monica Kalemba, Under Secretary, Ministry of Local Government, held July 25, 2006.

${ }^{456}$ Interview with Director Administrative Reform, Ministry of Public Service, Ms. Deborah Katuramu, held July 21, 2006.
} 
institutionalize ethical behavior. For instance, two ministers were recently censured by Parliament only to be reappointed to other Ministries by the President.

The study found that procurement and contract management are areas in which accountability remains a critical challenge. Currently, procurement is done in-house, ministry by ministry but there is weak capacity in procurement management, accounting, and auditing systems both at the central ministerial level and at local districts. Such phrases as "procurement is very problematic", "there is great need of training in management of tenders and contracts" were offered by many participants. Indeed, in 2005 , the WB observed that Uganda loses about US\$ 300 million through corruption and procurement malpractices per year. ${ }^{457}$ It was asserted that at the District and Regional Workshops held in different areas in preparation of the joint annual review of decentralization in 2004, long lists of different manifestations of corruption, ranging from influencing the operations of the district service commission, to irregularities with procurement, to embezzlement of funds, and forging of documents were yielded. ${ }^{458}$ Indeed it is safe to say that decentralization did not only devolve roles, functions, and resources to the local level, but devolved the maladies that afflicted the center as well.

There was a general consensus that despite the increase in government salaries, it was not enough to surmount the potential gains from unethical behavior like taking bribes, embezzlement, and corruption. Moreover, the decline in salary value as a result of increasing inflation did not make matters any easier. Even in the semi-autonomous

\footnotetext{
${ }^{457}$ The World Bank. 2005. Uganda: Country Report. Washington D.C.

${ }^{458}$ Interview DW - B0013.
} 
agencies, which when compared to the traditional public service earn higher salaries the situation is not any different. The case of the Uganda Revenue Authority (URA) is illustrative. Established in 1991 to oversee tax administration in the country, the URA depicts the internalization of the NPM ideals by the Ugandan government. Following NPM prescriptions, the URA was designed in such a way that management would have autonomy and would enjoy freedom over staffing and resource use. It was envisaged that highly skilled workers would be hired and paid very well to ensure hard work, motivation, discipline, and accountability. Indeed in the first few years following its establishment, URA performed well increasing revenue generation from 7 percent to 12 percent in five years but in 1998, the IGGs national integrity survey found that 40 percent of its respondents reported incidents of bribery with the URA officials. By 2000, there was widespread public outcry about corruption in the URA and in 2002, government put in place a commission of inquiry into corruption in the URA. ${ }^{459}$

The URA case shows that increasing salaries per se, may not be enough to ensure ethics and accountability. Corruption was not deterred by salary increases in the case of the URA. In their study of bureaucratic corruption, Rijckeghem and Weder (2001) found that despite a statistically significant relationship between civil service pay and corruption, it is not a given that corruption can be eradicated solely by raising wages. In

\footnotetext{
${ }^{459}$ For a detailed analysis of corruption in the URA see Tangri, R. and Andrew M. Mwenda. 2006. "Politics, Donors, and the Ineffectiveness of Anti-corruption Institutions in Uganda" Journal of Modern African Studies, Vol. 44, No. 1 pp. 101-124; Fjeldstad, Odd-Helge. 2005. "Corruption in Tax Administration: Lessons from Institutional Reforms in Uganda." CMI Working Paper; Therkildsen, O. 2004. "Autonomous Tax Administration in Sub-Saharan Africa: The Case of the Uganda Revenue Authority” Forum for Development Studies, Vol. 31, No. 1 pp. 59-88.
} 
their view, other mechanisms must be put in place, notably, "strengthening the rule of law., 460

Although high pay is generally considered as an incentive to not be vulnerable to corruption, in instances where corruption benefits are very high and the chance of being caught and held accountable are low, corruption will prevail. In the URA case, that seems to be the scenario. So far there are very few people that have been held accountable as a result of commissions of inquiry and other investigations into corruption in URA or the Uganda Police. This sends the wrong message to public servants and undermines any efforts towards ethics enhancement. As one participant observed;

"ethics and accountability also start from the leaders and the managers. If you have a ministry where the chief executive is not bothered about ethics and accountability, it will follow through, if you have political leaders who are not doing that, it will follow through. So it is a wider problem that you have to look at, at organization, you can work on your part but if the environment around you is not, it becomes difficult.",461

\subsection{CHALLENGES IN ENHANCING ETHICS AND ACCOUNTABILITY IN THE UGANDA CS}

The analysis offered above shows that ethics and accountability remain a challenge and the reform program has attained minimal success. In spite of government efforts to build and facilitate watchdog agencies, more needs to be done. Lack of financial and human resources have rendered the agencies ineffective in carrying out their mandates of monitoring, enforcement, and execution. Therefore the study contends that

\footnotetext{
${ }^{460}$ Rijckeghem, C. V. and Beatrice Weder. 2001. "Bureaucratic Corruption and the Rate of Temptation: Do Wages in the Civil Service affect Corruption, and by how much?" Journal of Development Economics, Vol. 65, pp. 307-331.

${ }^{461}$ Interview with Director Administrative Reform, Ministry of Public Service, Ms. Deborah Katuramu, held July 21, 2006.
} 
the reform initiatives to enhance ethics and accountability have had a limited impact in institutionalizing ethics and accountability in the civil service. Indeed, Uganda is rated among the most corrupt nations in the world by Transparency International. Table 6.16 below indicates Uganda's corruption perception index ranking for the years 1998-2008 by Transparency International.

Table 6.16 Uganda's Corruption Perception Index (CPI) Ranking, 1998-2008

\begin{tabular}{|c|c|c|c|}
\hline YEAR & FROM TOP & FROM BOTTOM & CPI SCORE \\
\hline 1998 & 73 out of 85 & $8^{\text {th }}$ & 2.6 \\
\hline 1999 & 87 out of 99 & $12^{\text {th }}$ & 2.2 \\
\hline 2000 & 80 out of 90 & $10^{\text {th }}$ & 2.3 \\
\hline 2001 & 88 out of 91 & $3^{\text {rd }}$ & 1.9 \\
\hline 2002 & 93 out of 102 & $9^{\text {th }}$ & 2.1 \\
\hline 2003 & 117 out of 133 & $19^{\text {th }}$ & 2.2 \\
\hline 2004 & 102 out of 145 & $43^{\text {rd }}$ & 2.6 \\
\hline 2005 & 117 out of 158 & $41^{\text {st }}$ & 2.5 \\
\hline 2006 & 105 out of 163 & $58^{\text {th }}$ & 2.7 \\
\hline 2007 & 111 out of 179 & $68^{\text {th }}$ & 2.8 \\
\hline 2008 & 126 out of 180 & $54^{\text {th }}$ & 2.6 \\
\hline
\end{tabular}

Source: Transparency International. www.transparency.org. Accessed November 3, 2008.

Table 6.16 indicates the degree to which corruption is perceived to exist among public officials and politicians in Uganda. The trend shows that the country has consistently scored poorly with the worst score attained in 2001 . The gradual improvement since then could be attributed to the various commissions of inquiry into corruption in the police and the Uganda revenue authority. The various institutions discussed above could also claim some of the credit. Nonetheless, ethics and accountability in the public service remain weak. The major problem in the CSRP and the quest for ethics and accountability is not a 
lack of institutional mechanisms to enhance ethics, but rather, it is the lack of monitoring, investigative, enforcement and prosecution capabilities by those institutions. Moreover, respect for the rule of law has not yet been entrenched, a fact manifested in the loud public outcries about corruption.

Yet, all is not lost. Some study participants were highly optimistic about the efforts being made to ensure ethics and accountability in the public service and some articulated what they perceive as real achievements that have been generated by the reform process. It was revealed that civil servants observe working hours better, and handle office equipment better. The revelation shows that even the smallest achievements that should be norm in any functional administrative system are in this case, applauded. It must be recalled that not too long ago, absenteeism and moonlighting, were the order of the day, public property and equipment were appropriated, and people reported for and left work anytime they pleased. Therefore, while it is evident that a lot still has to be done, it is important to not lose sight of the achievements so far attained however minor. Nonetheless, instituting ethics and accountability in the Uganda Civil Service are still predominantly rhetoric than reality.

\subsection{SUMMARY}

Chapter 6 described the major findings of the study. The government of Uganda has in the last 17 years sought to achieve major administrative, institutional, and structural reforms. The public service reform was geared towards not only revitalizing the public service, but also to engender good governance. Through a thick description based on the perceptions of Ugandan public servants, the chapter has demonstrated that a lot 
has been achieved. The size of public service was drastically reduced in an attempt to do more with less. The size of traditional civil service that was 140,500 in 1990 , was reduced drastically that in it was only 41,730 in 2004 . This reduction was attained through the removal of ghost workers, retrenchment of nonperformers and overdue leavers, and voluntary retirement. Government Ministries were also reduced from 38 in 1991 to the current number of 17 . Generally, the public sector structures were rationalized, modernized, and strengthened.

The results show that improvements were made through the pay reform. The pay structure and payroll were standardized and computerized, allowances and benefits were monetized and consolidated into basic salary, and salary was enhanced in real terms. The results also show that capacity building efforts have generated benefits. A training needs assessment was undertaken in all Ministries, and training policy was formulated to guide training of staff. Various training programs have been undertaken and personnel skills have been enhanced. In addition, efforts to recruit professional and technical workers with the necessary skills are being made.

The results also show that ethics and accountability are still lagging behind expectations. Where as government watchdog bodies have been instituted or reenergized, there is a strong perception that corruption and lack of accountability are still on the rise.

Despite the achievements attained, a number of problems were found to still beleaguer CSRP implementation. Although the traditional size of the civil service reduced, it is increasing again. The main cause is the hire of primary school teachers to cater to the increase in primary school enrollment. Although this increase is justified, the fact that it was not planned for in the reform strategy means that unforeseen problems 
have emerged. For instance the pay reform slowed down because of this increase. In addition, the number of districts has increased as has the "shadow government" in the form of presidential advisors.

Pay reform that initially generated impressive success has stagnated. Failure to abide by the single spine salary structure as prescribed by the pay strategy is one of the reasons for the stagnation. The major problem in this area however, is political influence. Presidential directives to increase salary for certain groups of civil servants has disrupted pay reform and caused inconsistencies. The gradual increase in the size of the civil service too, has negatively affected pay reform. There is evidence that political will to increase pay has over time waned. It is not uncommon for money budgeted for salaries to be reallocated to other areas like defense. Low salaries in turn make it difficult to attract and retain skilled workers. Inadequate remuneration and sometimes inappropriate incentives and work tools exacerbate the deficiencies in the public service capacity and performance.

Capacity building has also suffered some set backs, notably lack of financial resources. Civil servants are eager and willing to get better training and acquire modern and relevant skills, but are incapacitated by limited financial support. Ethics and accountability have also lagged behind because of lack of human and financial resources to enable watchdog agencies to carry out their mandates. Because so few public servants have been executed for unethical conduct, there is no urgency for change of behavior. Needless to say, corruption and lack of viable accountability and conduct rules enforcement mechanisms undermine performance and service delivery. 
It can therefore be asserted that as the reform process progressed, apparent loss of strategic focus and inertia in the implementation process began to emerge. The overall cause is lack of political legitimacy. Although elections are periodically held, there is a general view that they are not free and fair. As a result, civil wars have been raging in the eastern and northern parts of the country. Not surprisingly, political enthusiasm for civil service reform has overtime diminished. The political leadership is preoccupied with survive to the detriment of the reform program. For instance, the share of government expenditure on defense has consistently exceeded that of the other sectors; to garner political support, selective pay enhancement is offered; and corrupt officials from areas that provide critical votes are not punished and in some instances they are rewarded with ministerial positions. Such occurrences generate resentment in the civil service and open avenues for corruption.

My study contends that, lack of political legitimacy, reactive leadership, and poor reform strategies underlie the reform's weaknesses. The Uganda civil service remains weak and fragile to effectively discharge its mandates. Much remains to be done to have in place a workforce that is well-trained, competent, motivated, and able to efficiently deliver high quality services to the public.

It can therefore be concluded that the reform program has not yet rebuilt the public service to the level where it can champion sustained economic growth and development, and consistent poverty eradication. Until the goals and objectives of the reform program namely; the creation of a small, motivated, efficient, effective, and accountable civil service are fully attained and put on a steady path, good governance 
will remain a mirage and the reality of the civil service reform program in Uganda will remain in deep contrast with the rhetoric. 


\section{CHAPTER 7: THE CIVIL SERVICE REFORM PROGRAM IN TANZANIA: AN ANALYSIS OF THE FINDINGS}

\subsection{INTRODUCTION}

The discussion in chapter five addressed the nature of the political-economic systems adopted by the Tanzanian government soon after independence and showed that the single party system of government and the socialist economic orientation were not conducive strategies to national development. Contrary to expectations, economic decline ensued and generated adverse effects in all sectors of government. The civil service performance rapidly deteriorated as salaries plummeted and grim working conditions became the norm. Chapter five also addressed the various efforts that were undertaken to curtail the decline and noted that most of the reform focused on the economy. It was not until 1990 that direct attention was paid to the administrative system. In 1991, the government of Tanzania launched the Civil Service Reform Program (CSRP). The objective of the reform was to attain a "smaller, affordable, well-compensated, efficient and effectively performing civil service working to implement redefined policies and strategies for national economic development and delivery of public services.” ${ }^{„ 462}$

Chapter seven presents the results and analyzes the Tanzanian civil service reform based on the data generated from interviews held with officials from the President's Office - Public Service Management (PO-PSM), the Ministry of Education (MOE), the Ministry of Finance (MOF), the President's office - Regional Administration and Local Government (RALG) and data from official government documents and various

\footnotetext{
${ }^{462}$ United Republic of Tanzania, President's Office - Civil Service Department. 1999. Civil Service Reform Programme: Implementation Status Report (1993-1999). Dar es Salaam, p. 5.
} 
websites. The current study focused its analysis on four major aspects of the reform program namely; (i) the reduction of the size of the civil service, (ii) pay reform, (iii) capacity building, and (iv) ethics and accountability. The following questions guided this analysis; 1) has the size of the civil service been reduced? To what levels? 2) Are the civil servants well paid and motivated? 3) Is capacity being built? In what areas/ways? 4) Are ethics and accountability improving? What are the indicators? Chapter seven attempts to answer these questions based on the realities on the ground derived from the interviews held with senior government officials and data from the various government documents, published work and the internet.

The analysis of the findings is based on the themes that categorize the perceptions of the study participants about the four major aspects of the reform program that the study focuses on. The overall themes that emerged from my respondents' perception of the reform program are: doing more with less; improving remuneration; human resources development and capacity building; enhancing ethics and accountability; and economic recovery and poverty eradication. The themes are the basis of the analytical discussion of results offered below. The analysis is provided in four major sections and each deals with one of the four aspects of the reform program. Under each section, subsections detailing the context before the reform, the goals of the reform, the implementation, and the whether the goals were attained are offered.

\subsection{REDUCTION OF THE SIZE OF THE TANZANIAN CIVIL SERVICE}

At independence in 1961, the Tanzanian civil service was small and worked quite well until 1973 when the economy began a downward spiral as a result of the world-wide 
oil shocks, and poor domestic policies. The economic crisis had an adverse effect on all sectors of government but the CS in particular came under great financial strain; salaries deteriorated and overstaffing ensued as private sources of employment disappeared. In 1966 there were 65,708 established CS positions and in 1972 the number had increased to 101,181 . By 1976 , the number had increased to 191,046 , in 1980 it was 295,352 , and in 1992 , the number of civil servants was $354,612 .^{463}$

The rapid increase in the size of the CS was justified by government as a consequence of increased duties and responsibilities resultant from the Arusha Declaration of 1967. However, scholars attributed the increase to tribalism and nepotism. Mutahaba (1975) asserted that the rapid increase was due to recruitment of relatives by senior civil servants. "They cannot support them for too long on the incomes they are left with after taxes, so they do what seems the most logical thing to do, have them placed in

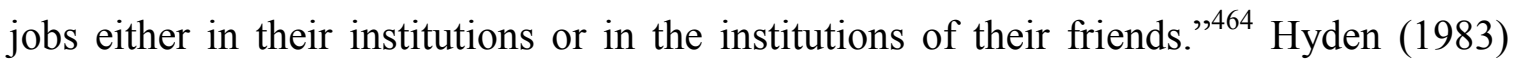
argues that it is "the economy of affection" 465 in which individuals invest in reciprocal relations with other individuals as a means of attaining goals that would otherwise be unattainable through formal channels that led to high growth rates of the civil service. Both arguments are quite valid. The control of the economy's commanding heights by the government and the creation of numerous parastatal agencies expanded government

\footnotetext{
${ }^{463}$ United Republic of Tanzania. President's Office - Civil Service Department. 1999. Civil Service Reform Programme Implementation Status Report (1993 - 1999). Dar es Salaam.

${ }^{464}$ Mutahaba, G. 1975. "The Effect of Changes in Tanzania Public Service System Upon Administrative Productivity, 1961-1972.” African Review, Vol. 5 No. 2, p. 206.

${ }^{465}$ Hyden, G. 1983. No shortcuts to Progress: African Development Management Perspective. Berkeley: University of California Press.
} 
services and activities and necessitated more staff. Mutahaba's and Hyden's arguments hold some truth as well because in most of Africa and many other countries, patronage obligations pervade the administrative system. It is the contention of this study however that it was not only the developmental state and primordial tendencies that led to the increase of the CS numbers. Rather, it was in addition, the failure to abide by the Weberian bureaucratic ideals left in place by the colonial administration at independence. Failure to abide by establishment and payroll controls, political interference in appointments, distortions and inequities in promotion and compensation, and corruption, led to overstaffing in the CS.

As the CS numbers were steadily increasing, the economy was quickly backsliding. Consequently, budgetary allocations dwindled, inflation skyrocketed, the debt burden increased, and civil service salaries lost value. These conditions created a negative chain reaction on administrative performance. Civil servants neglected their duties and took on other jobs to supplement their meager incomes, rules and regulations were ignored, accountability mechanisms collapsed, corruption blossomed, and the civil service became increasingly bloated with very many people doing very little work.

It is in response to this context that the CSRP was initiated. With assistance from the WB and IMF, Tanzania implemented stabilization and SAPs to return the country to macroeconomic equilibrium and economic growth. It was however quickly realized that a bloated, nonperforming civil service would be detrimental to the economic reform that was underway. The country therefore committed itself to reduce the size of the CS in response to fiscal deficits and donor pressure. 


\subsubsection{Doing More with Less: The Reduction of the Size of the Tanzanian Civil Service}

In 1989, a WB assessment of public expenditure in the country found that in the period 1970-1984, government employment grew twice as much as government revenues. Approximately $72 \%$ percent of all formal employment in the country was provided by the public service. ${ }^{466}$ The Tanzanian CSRP therefore was launched in 1991 and put into effect in 1993 with the assistance of the WB and IMF under the SAPs framework to rectify the situation. The Civil Service Department (CSD) in the office of the President was charged with the implementation and execution of the CSRP. It was envisaged that the reform program would cost US \$25.8 million and an additional US $\$ 15$ million would be required to cover the reform of local government. The major financial donors were the WB, the United Nations Development Programme (UNDP), the European Union (EU), and the British Overseas Development Agency (ODA).

During the first phase of the reform program, 1993-999, focus was placed on the reduction of the size of the service. The government realized that if it was to improve civil service performance and service delivery, the numbers had to be drastically reduced. According to the former Permanent Secretary for the PO-PSM, the civil service had to be reduced in size because the required budgetary expenditure was not feasible. "The budget crisis called for the redefinition of the role and function of government. Rationalization of government employment was pursued because vital functions and services were

\footnotetext{
${ }^{466}$ McCourt, W. and Nazar, Sola. 1999. "Using Training to Promote Civil Service Reform: A Tanzania Local Government Case Study.” Public Administration and Development, Vol. 19, pp. 63-75.
} 
underfunded."467 The goal here was to retain a small, affordable service that is skilled, well paid, and motivated. According to the former Permanent Secretary, PO-PSM, the vision of the reform was to "evolve a smaller but more efficient and effective civil service.....a service characterized by meritocracy, professionalism, high integrity, transparency, accountability, as well as impartiality and objectivity in decision making.",468

The quest to reduce the size of the service was undertaken through three major ways namely; organization and efficiency reviews, personnel control and management, and rationalization of government employment.

\subsubsection{Organization and Efficiency Reforms}

The objectives of the Organization and Efficiency (O\&E) reforms were to streamline the government structure and to rationalize its functions and systems in order to increase efficiency and effectiveness in service delivery. In addition, they were aimed at reducing government operations by relinquishing to private agencies those functions that did not form the core business of government but which were critical to the delivery of services. Organization and efficiency reforms were in line with the WB and IMF prescription that government divests from direct production and delivery of services that could be ably provided by the private sector so that it focuses on facilitation, regulation,

\footnotetext{
${ }^{467}$ Interview with Mr. Joseph Rugumyamheto, former Permanent Secretary, The President's Office-Public Service Management, held June 29, 2006.

${ }^{468}$ Interview with Mr. Joseph Rugumyamheto, former Permanent Secretary, The President's Office - Public Service Management, held June 29, 2006.
} 
and monitoring of private operations. The organization and efficiency reforms were undertaken in three phases by a Task Force that was comprised of the Deputy Principal Secretaries from the Treasury, the President's Office, the Prime Minister's Office, the Planning Commission, the Director of Management Services in the CSD, and the CSRP Secretariat. The Task Force reviewed the background information and previous reports, held interviews with high level management officers in each ministry, and came up with recommendations. Figure 7.1 shows the phases of the Ministerial Organization and Efficiency Review.

Figure 7.1 Phases of the Ministerial Organization and Efficiency Review

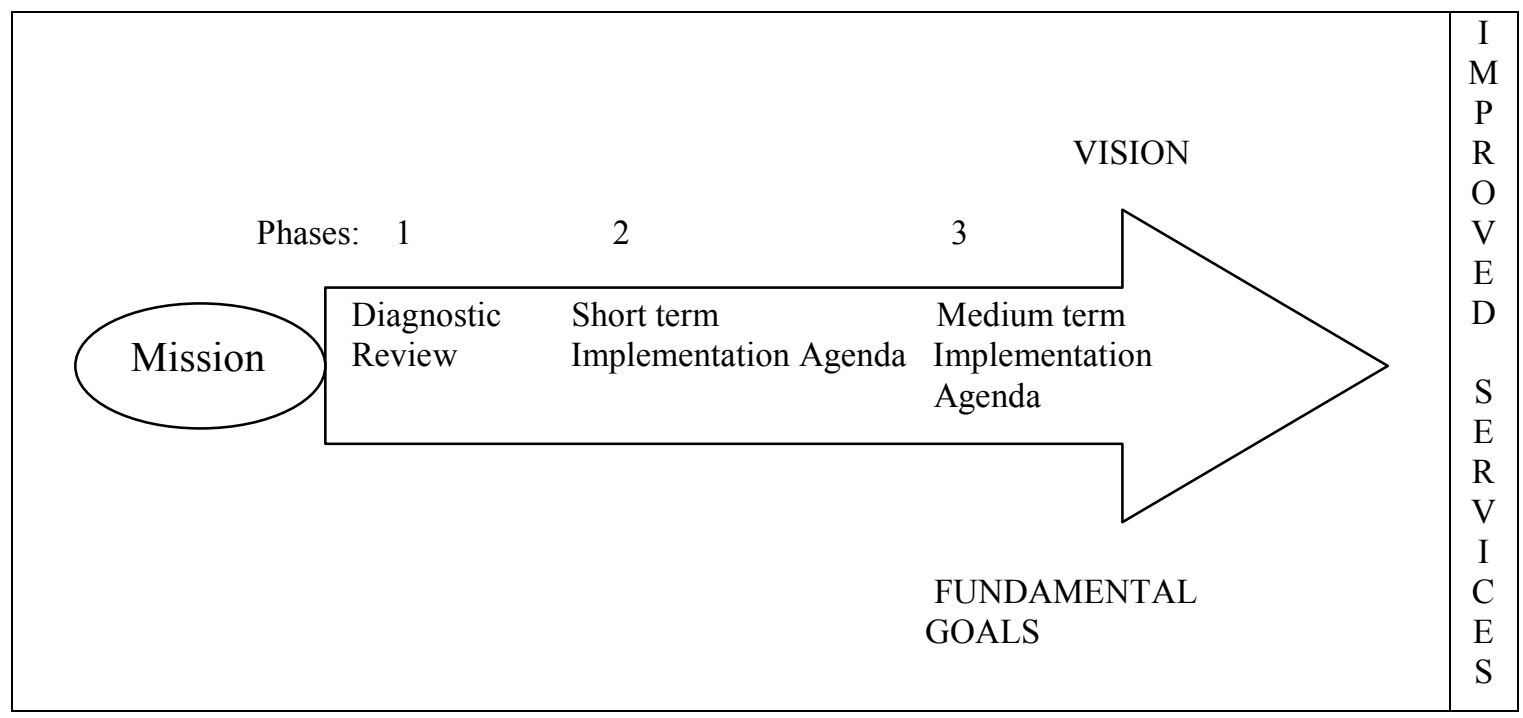

Source: Ntukamazina, D. A. 1998. "Civil Service Performance in Tanzania: A Strategic Perspective." In Severine M. Rugumamu (ed) Civil Service Reform in Tanzania: Proceedings of the National Symposium. Dar es Salaam: University Consultancy Bureau, p. 49.

The first phase of the review of the ministerial structures and functions was implemented in the Civil Service Department, the Planning Commission, the Ministry of Finance, and the Prime Minister's Office. These are essential ministries responsible for the planning, coordination, resource allocation, and monitoring functions of government. 
By 1996, all the 23 government ministries had been reviewed. The diagnostic reviews which constituted the first phase of the O\&E generated data regarding various issues including pay and motivation, personnel levels, training, and training needs. The reviews provided a clear description of the functions and organizational structures of the ministries and indicated their roles and functions. For instance, the Task Force recommended divestiture of revenue collection from the Ministry of Finance to an autonomous Revenue Authority - the Tanzania Revenue Authority (TRA). The TRA is among the many autonomous executive agencies that were recommended by the O\&E reforms and later established by the Executive Agencies Act of 1997.

The second of phase of O\&E reforms shifted the review process from being a preserve of the Task Force to Ministerial Reform Committees (MRC) set up in each government Ministry to oversee internal restructuring. Every Ministry formed a Technical Task Group (TTG) to address the specific issues including rationalization of functions and structures, determination of personnel levels, rationalization of planning and budgeting systems, staff development, job description, establishment of management information systems, and legal and regulatory frameworks. It is the reports of the various Ministries that guided the ministerial reductions and the creation of additional executive agencies. In 1993 when the Organization and Efficiency reforms were started, the Tanzanian CS was comprised of 23 ministries and by 1997 they had been reduced to 18. ${ }^{469}$ At the time of field data collection in 2006, restructuring of Ministries,

\footnotetext{
${ }^{469}$ Ntukamazina, D. A. 1998. "Civil Service Performance in Tanzania: A Strategic Perspective." In Severine M. Rugumamu (ed.) Civil Service Reform in Tanzania: Proceedings of the National Symposium. Dar es Salaam: University Consultancy Bureau.
} 
Departments, and Agencies (MDAs) was still underway. The process is guided by a demand-driven approach arising from MDAs internal organization and efficiency assessment.

During the third phase of the ministerial organization and efficiency reviews, the medium term implementation agenda was considered. The phase focused on restructuring the local government and implementing decentralization, contracting out of non-core functions among them security, cleaning, and grounds maintenance, and the creation of executive agencies. The reform of the local government was outlined in the Local Government Reform Agenda which was formulated in 1996 and endorsed by the Government in 1998. The major objective in reforming the local governments was to improve service delivery to the general public by transferring power, functional responsibilities, and resources from the central government to local government authorities (decentralization by devolution). The specific objectives of the reform were:

- to improve the autonomy of local authorities

- to improve the responsiveness of local authorities to local priorities as expresses through democratic organs

- to improve council resource mobilization from all sources

- to improve the operational efficiency of councils. ${ }^{470}$

It was envisioned that after the reform local government authorities would have the following characteristics:

\footnotetext{
${ }^{470}$ Therkildsen, O. 1998. "Challenges of Local Government Reform.” In Severine M. Rugumamu (ed.) Civil Service Reform in Tanzania: Proceedings of the National Symposium. Dar es Salaam: University Consultancy Bureau, p. 120.
} 
- Largely autonomous institutions free to make policy and operational decisions consistent with the laws of the land and government policies

- Strong and effective institutions underpinned by possession of resources (both human and financial) and authority to perform their roles and functions

- Institutions with leaders who are elected in a fully democratic process

- Institutions which will facilitate participation of people in planning and executing their development plans and foster partnerships with civic groups

- Institutions with roles and functions that will correspond to the demand for their services and

- Institutions which operate in a transparent and accountable manner. ${ }^{471}$ Implementation of the Local Government Reform Program (LGRP) began in 2000 and was to be undertaken in three one-year phases. The first phase involved 38 Councils and it was estimated that in one year, 35 Districts would be restructured such that at the end of the third phase, all Districts (96) would be fully functional within a decentralized system. Under the decentralization by devolution framework, Tanzanians directly elect representatives to a District Council, the local government governing body. A District Council is typically made of twenty members, one from each ward (a typical District has about twenty wards), who in turn elect the Council Chairperson. Urban areas are organized in Town Councils, Municipal Councils and City Councils depending on their populations. The ultimate goal of the LGRP is to have viable Councils that raise and

\footnotetext{
${ }^{471}$ United Republic of Tanzania. 1998. Policy Paper on Local Government Reform. Dar es Salaam.
} 
manage their finances, hire and fire their own staff, and provide such services as agriculture, education, and health to the people.

According to the Program Manager for the LGRP, the reform has not yet helped to decongest the center. Confining Ministries to policy making, regulation, monitoring, performance assessments, and interventions to ensure the legality of public service provision while actual program implementation is undertaken by local governments was among the reasons decentralization was adopted. He revealed that the implementation of the LGRP as initially designed was too ambitious and generated minimal progress. Consequently the implementation timeframe was extended to five years. ${ }^{472}$ In 2006 , restructuring was still going on in the initial 38 Councils and an additional 52 had just embarked on the reform. The slow progress in restructuring the local governments has meant that the staff reduction at the center has not progressed as originally envisaged. Consequently, decline in operational staff within the central Ministries has been very slow. Figure 7.2 shows the percentage of public servants who are operational staff for the years 2000 to 2006 operating within Ministries at the national level.

The restructuring of Ministries, Departments and Agencies, the creation of executive agencies, and contracting out of non-core services coupled with decentralization should all contribute to the reduction of the number of the civil service staff especially, the operational staff. However, as long as the decentralization program stalls and operational staff remain at the center, staff reduction will not be effected.

\footnotetext{
${ }^{472}$ Interview with Mr. Alfred Kamugile, Program Manager, Local Government Reform Program, held August 1, 2006.
} 
Indeed from the year 2000 when the LGRP was initiated, only a small decline in the percentage of operational staff at the center (from 16\% to 13.5\%) has been attained.

Figure 7.2 Percentage of Public Servants who are Operational Staff in Central Ministries at the National level for the Years 2000 to 2006

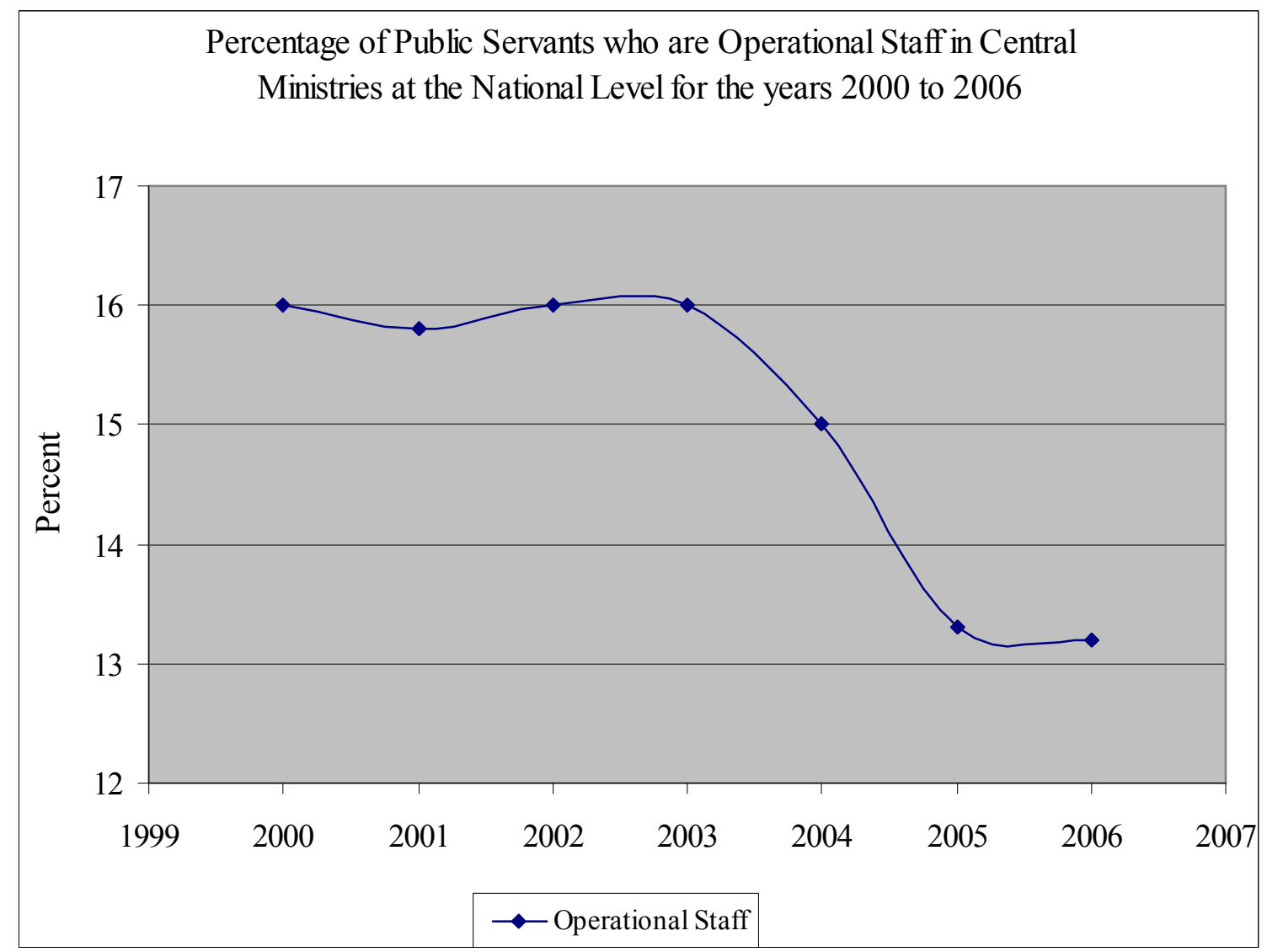

Source: United Republic of Tanzania, President's Office - Public Service Management. 2008. PSRP Phase 1 End of Programme Report: A Summary of Results 2003-2007. Dar es Salaam, p. 26

It was revealed that in addition to the fact that LGRP has not progressed on course, only a small number of Ministries have ceded minimal power to the restructured districts. It is anticipated however that as decentralization efforts take root, operational staff that undertake direct job performance and responsibilities will shift in greater numbers to the local level thereby reducing the number of staff in the traditional public service. 
Contrary to the little success that has been attained in decongesting the center and relieving it of functions that deal with local government, similar efforts at the regional governments have fared better. Under phase 1 of the LGRP, regional administration roles and structures were reduced to technical secretariats and the functions of regional tiers of government were limited to co-ordination and technical support to local authorities. As a result, "staffing numbers at the regional level has been reduced from an average of 700 per region to 83. Total Staff numbers have been reduced approximately from 14,000 to $2,000 ., 473$

If success in reducing the CS size by restructuring local governments has not been forthcoming, contracting out non-core functions and the creation of executive agencies under the organization and efficiency reviews have had better luck. It was revealed that by contracting out services, the number of lower cadre staff was reduced.

"We have cut back staff numbers by contracting out many services. Fifty noncore services have been contracted out. For instance messengers, tea people, and those security people you saw at the gate are contract workers. We just hire companies and offload the problem. We want to only worry about teachers, doctors, surveyors, economists etc. We are even reducing the number of personal secretaries because most of our staff are now computer literate and have personal computers. So why have secretaries?",474

At the time of data collection, 68 contracts had been signed with private sector suppliers to provide non-core services and 128 were under formation to be finalized in 2007. Table 7.1 below shows some of the contracts for services that are being provided

\footnotetext{
${ }^{473}$ Interview with Mr. Alfred Kamugile, Program Manager, Local Government Reform Program, held August 1, 2006.

${ }^{474}$ Interview with Professor Gelase Mutahaba, Chief Technical Advisor, President's Office - Public Service Management, held June 29, 2006.
} 
by the private sector. In addition to contracting out non-core services, executive agencies were established to enable the Ministries to relinquish functions that could be carried out independently from Ministerial Headquarters.

Table 7.1 Private Sector Participation in the Provision of Non-core Services

\begin{tabular}{|c|c|c|c|c|c|c|}
\hline \multirow{2}{*}{$\begin{array}{l}\text { CONTRACTS SERVICE } \\
\text { NAME }\end{array}$} & \multicolumn{2}{|c|}{ A. COMPLETED } & \multicolumn{2}{|c|}{ B. IN PROGRESS } & \multicolumn{2}{|c|}{ C. TOTAL } \\
\hline & NUMBER & $\%$ & NUMBER & $\%$ & NUMBER & $\%$ \\
\hline Aircraft Cleaning & 0 & 0.0 & 1 & 0.8 & 1 & 0.5 \\
\hline Canteen & 0 & 0.0 & 1 & 0.8 & 1 & 0.5 \\
\hline Catering or Cafeteria & 3 & 4.4 & 11 & 8.6 & 14 & 7.1 \\
\hline $\begin{array}{l}\text { Cleaning and grounds } \\
\text { Maintenance }\end{array}$ & 27 & 39.7 & 36 & 28.1 & 63 & 32.1 \\
\hline Estate Management & 0 & 0.0 & 1 & 0.8 & 1 & 0.5 \\
\hline Gravel Pack Supply & 0 & 0.0 & 1 & 0.8 & 1 & 0.5 \\
\hline Housing Maintenance & 0 & 0.0 & 1 & 0.8 & 1 & 0.5 \\
\hline Laundry & 0 & 0.0 & 3 & 2.3 & 3 & 1.5 \\
\hline $\begin{array}{l}\text { Maintenance of Motor } \\
\text { Vehicles }\end{array}$ & 0 & 0.0 & 2 & 1.6 & 2 & 1.0 \\
\hline $\begin{array}{l}\text { Maintenance of Office } \\
\text { Machines and Equipment }\end{array}$ & 4 & 5.9 & 15 & 11.7 & 19 & 9.7 \\
\hline Messenger Services & 1 & 1.5 & 3 & 2.3 & 4 & 2.0 \\
\hline Photocopy and Binding & 1 & 1.5 & 2 & 1.6 & 3 & 1.5 \\
\hline $\begin{array}{l}\text { Preparation and Conduction } \\
\text { of Weights and Measures } \\
\text { Exam }\end{array}$ & 0 & 0.0 & 1 & 0.8 & 1 & 0.5 \\
\hline Secretarial Services & 2 & 2.9 & 0 & 0.0 & 2 & 1.0 \\
\hline Security and Reception & 29 & 42.6 & 40 & 31.3 & 69 & 35.2 \\
\hline $\begin{array}{l}\text { Student and Staff } \\
\text { Accommodation }\end{array}$ & 0 & 0.0 & 2 & 1.6 & 2 & 1.0 \\
\hline $\begin{array}{l}\text { Supply of Goods and Works } \\
\text { Services }\end{array}$ & 1 & 1.5 & 1 & 0.8 & 2 & 1.0 \\
\hline Tailoring & 0 & 0.0 & 1 & 0.8 & 1 & 0.5 \\
\hline Transport of Staff & 0 & 0.0 & 5 & 3.9 & 5 & 2.6 \\
\hline $\begin{array}{l}\text { Utility Repair and } \\
\text { Maintenance }\end{array}$ & 0 & 0.0 & 1 & 0.8 & 1 & 0.5 \\
\hline TOTAL & 68 & 100 & 128 & 100 & 196 & 100 \\
\hline
\end{tabular}

Source: United Republic of Tanzania, President's Office - Public Service Management. 2008. PSRP Phase 1 End of Programme Report: A Summary of Results 2003 -2007. Dar Es Salaam, p. 24.

Notes: "Number" = Number of Contracts.

According to the Assistant Commissioner of Budget in the MOF, agencies were designed to relieve Ministries of unnecessary responsibilities so that they could 
concentrate on their major roles of policy development, setting standards, monitoring, and evaluation of implementation. ${ }^{475}$ Agencies were to be guided by private business financial management systems of operation and were individually designed to deliver specific services. It was envisaged that such an arrangement would not only generate efficiency and effectiveness in the delivery of public services, but would also contribute to revenue generation. At the time of data collection, there were 21 fully operational autonomous executive agencies while another 15 were in advanced stages of formation. Appendix 4 provides the list of the agencies and their responsibilities.

The study interviewees were in agreement that the formation of agencies has not only reduced traditional civil service numbers, but has also improved revenue generation. "Revenue collection has significantly improved" said the Commissioner of Budget in the MOF. "On average, agencies collect $25 \%$ more revenue than they did when they were Ministerial departments. In 7 of the 11 agencies in which we have undertaken time series data collection, revenue collection trends improved rapidly once departments became agencies. ${ }^{276}$ It was revealed that agency performance has improved because of the numerous capacity development initiatives the agencies have undertaken. Recruitment of Senior Managers, Service Delivery Surveys, Commercialization of Accounts, Client Service Charters, and Open Performance Review Appraisal Systems (OPRAS) are some of the innovative initiatives undertaken. Training has also been offered in such areas as

\footnotetext{
${ }^{475}$ Interview with Mr. Ramadhani, S. Hamisi, Assistant Commissioner of Budget in the MOF, held July 31, 2006.

${ }^{476}$ Interview with Mr. Magambo Nashon, B. S., Commissioner of Budget, MOF, held July 31, 2006.
} 
Asset Valuation, Integrated Financial Management Systems (IFMS), and Results Oriented Management. ${ }^{477}$

Overall, the Organization and Efficiency reviews have generated a decrease in the number of civil servants through ministerial rationalization and restructuring. The number of line divisions within Ministries was reduced by $25 \%$ while the Ministry sections were reduced by $35 \%$ (see Table 7.2 below). Within the central Ministries, the Ministry of Finance had the highest reduction of 36 units from an original 72, followed by the Civil Service Department which got rid of 14 units of the original 30. Combined, the central Ministries reviewed in the period 1994-1997 underwent a 76\% reduction in their Divisions and Sections. The other major reduction was effected in the Economic/Productive Sector, notably in the Works Division and Section which was reduced from 26 to 6 respectively. Extra staff reductions were generated by contracting out of non-core services and by establishing executive agencies.

However, despite the achievements indicated above, it is important to note that Organization and Efficiency reform efforts have not accomplished the complete restructuring of the Tanzanian CS. At present, all the potential executive agencies have not been identified and formed, and not all non-core services have been outsourced. In addition, the Ministries, Departments, and Agencies do not focus all their activity solely on policy and regulatory functions because the decentralization program stalled. The central government is still directly involved in the delivery of services and direct job performance, functions that require large numbers of operational staff. Consequently, the

\footnotetext{
${ }^{477}$ Ibid.
} 
role and functions of government have been reduced only minimally and staffing levels are still high. Ultimately, the implementation of the O\&E component will remain partially successful.

\subsubsection{Personnel Control and Management}

The reduction of the size of the Tanzanian CS was also undertaken via personnel control and management reforms. Prior to the reforms, "there was uncontrolled growth of the CS, employment rules and regulations were ignored, and appointments did not target requisite skills." ${ }^{478}$ The objective of the personnel control and management reforms therefore was to institute policy and systematic control to monitor the numbers and quality of the personnel recruited into the CS. According to the Chief Technical Advisor, PO-PSM, personnel control and management entailed "setting minimum standards for entry into the civil service, establishing a management audit unit, streamlining the flow of information from the Ministries to the CSD, producing job descriptions for all civil servants, and putting in place performance assessment measures." ${ }^{, 49}$ To ensure that personnel control and management mechanism are put on place, the Tanzanian government passed the Human Resources Management and Employment Policy in 1999 and supplemented it with a new Public Service Act in 2002. Both documents have been crucial in guiding the restoration of meritocracy in the management of personnel in the CS.

\footnotetext{
${ }^{478}$ Interview with Professor Gelase Mutahaba Chief Technical Advisor, President's Office - Public Service Management, Government of Tanzania, held June 29, 2006.

${ }^{479}$ Ibid.
} 
Table 7.2 Impact of Organization and Efficiency Review (O\&E) 1993-1997

\begin{tabular}{|c|c|c|c|c|c|c|}
\hline \multirow[b]{2}{*}{ MINISTRIES } & \multicolumn{3}{|c|}{$\begin{array}{c}\text { LINE } \\
\text { DIVISIONS }\end{array}$} & \multicolumn{3}{|c|}{ SECTIONS } \\
\hline & Pre $\mathbf{O} \& \mathbf{E}$ & $\begin{array}{c}\text { Approved } \\
\text { New } \\
\text { Structures }\end{array}$ & Reductions & Pre O \& E & $\begin{array}{c}\text { Approved } \\
\text { New } \\
\text { Structures }\end{array}$ & Reductions \\
\hline \multicolumn{7}{|l|}{ CENTRAL MINISTRIES } \\
\hline Finance & 13 & 8 & 5 & 59 & 28 & 31 \\
\hline Planning Commission & 10 & 5 & 5 & 18 & 12 & 6 \\
\hline Civil Service Department & 4 & 4 & 0 & 26 & 12 & 14 \\
\hline Prime Minister's Office & 5 & 5 & 0 & 17 & 14 & 3 \\
\hline Sector Totals & 32 & 22 & 10 & 120 & 66 & 54 \\
\hline Percentages & 100 & 69 & 31 & 100 & 55 & 45 \\
\hline \multicolumn{7}{|l|}{ SOCIAL SERVICES SECTOR } \\
\hline Education & 5 & 4 & 1 & 13 & 10 & 3 \\
\hline $\begin{array}{l}\text { Science, Technology, and } \\
\text { Higher Education }\end{array}$ & 3 & 3 & 0 & 8 & 6 & 2 \\
\hline Health & 6 & 3 & 3 & 25 & 13 & 12 \\
\hline $\begin{array}{l}\text { Community Development, } \\
\text { Gender and Culture }\end{array}$ & 5 & 3 & 2 & 8 & 10 & 2 \\
\hline $\begin{array}{l}\text { Labour and Youth } \\
\text { Development }\end{array}$ & 3 & 3 & 0 & 11 & 9 & 2 \\
\hline Sector Totals & 22 & 16 & 6 & 65 & 48 & 21 \\
\hline Percentages & 100 & 73 & 27 & 100 & 74 & 32 \\
\hline \multicolumn{7}{|l|}{ ECONOMIC/PRODUCTIVE SECTOR } \\
\hline $\begin{array}{l}\text { Lands and Human Settlements } \\
\text { Development }\end{array}$ & 4 & 3 & 1 & 17 & 12 & 5 \\
\hline Industry and Commerce & 3 & 2 & 1 & 5 & 7 & 2 \\
\hline Works & 8 & 2 & 6 & 18 & 4 & 14 \\
\hline Communications and Transport & 2 & 1 & 1 & 7 & 4 & 3 \\
\hline Water & 3 & 3 & 0 & 12 & 8 & 4 \\
\hline Energy and Minerals & 2 & 2 & 0 & 8 & 8 & 0 \\
\hline Natural Resources and Tourism & 3 & 4 & 1 & 10 & 15 & 5 \\
\hline Agriculture and Co-Operatives & 4 & 4 & 0 & 13 & 11 & 2 \\
\hline Sector Totals & 29 & 21 & 10 & 90 & 69 & 35 \\
\hline Percentages & 100 & 72 & 34 & 100 & 77 & 39 \\
\hline \multicolumn{7}{|l|}{ ADMINISTRATIVE SECTOR } \\
\hline Home Affairs & 5 & 5 & 0 & 19 & 20 & 1 \\
\hline $\begin{array}{l}\text { Foreign Affairs and International } \\
\text { Cooperation }\end{array}$ & 5 & 5 & 0 & 14 & 15 & 1 \\
\hline Justice and Constitutional Affairs & 4 & 4 & 0 & 14 & 10 & 4 \\
\hline President's Office(State House) & 3 & 3 & 0 & 11 & 10 & 1 \\
\hline Vice-President's Office & 2 & 2 & 0 & 5 & 4 & 1 \\
\hline Defense (reviewed outside CSR) & n.a & n.a & n.a & n.a & n.a & n.a \\
\hline Sector Totals & 19 & 19 & 0 & 63 & 59 & 8 \\
\hline Percentages & 100 & 100 & 0 & 100 & 94 & 13 \\
\hline TOTALS & 102 & 78 & 26 & 338 & 242 & 118 \\
\hline PERCENTAGES & 100 & 76 & 25 & 100 & 72 & 35 \\
\hline
\end{tabular}

Source: United Republic of Tanzania, President's Office - Civil Service Department. 1999. Civil Service

Reform Program Implementation Status Report (1993-1999). Dar es Salaam, p. 14. 
Personnel control and management reforms generated an effective personnel information system that has streamlined civil service employment. All positions and employment are tracked by the integrated human resources control mechanism known as the Human Capital Management Information System. "This system is controlled by the President's Office - Office of Public Service Management and the Ministry of Finance jointly. It is difficult to tamper with." ${ }^{480}$ In addition, entry into and exit from the CS is handled systematically across all Ministries. All new employment has to be authorized by the Chief Secretary to the Government who also occupies the positions of Secretary to President, Secretary to Cabinet, and Head of the Public Service.

In a bid to ensure strict personnel control and management, payroll control measures were instituted in the MOF. The measures were put in place to monitor whether the wage bill expenditures were consistent with the staff numbers. An official from the Ministry of finance revealed that:

"A fully integrated human resources and payroll management system was installed. At its heart is a computerized human resources database that contains all the personal, professional, and career information for the country's 286,000 public servants. This system has enhanced our human resource management information and made it possible to control and predict payroll costs. It has brought back into the civil service payroll integrity and helped us get rid of ghost workers." ${ }^{\text {481 }}$

Data from government documents and views from the participants confirm that the above measures have generated reductions in the size of the civil service by not only

\footnotetext{
${ }^{480}$ Interview with Professor Gelase Mutahaba Chief Technical Advisor, President's Office - Public Service Management, Government of Tanzania, held June 29, 2006.

${ }^{481}$ Interview with Mr. Ramadhani, S.S. Hamisi, Assistant Commissioner, Budget, MOF, held July 31, 2006.
} 
rationalizing employment procedures but also by ensuring that the problem of ghost workers was solved. A participant revealed that "radical measures were taken where all public servants instead of getting salaries straight in our accounts we had to go physically to the bank cash office with our identity cards to get our salaries and that is how lawful workers were identified." ${ }^{482}$ By 1998, 20,000 ghost workers had been removed from the payroll saving the country at least Tshs. 7.2 billion per year. ${ }^{483}$ It was observed that in 2006, the ghost workers phenomenon was almost zero. ${ }^{484}$

\subsubsection{Rationalization of Government Employment}

In addition to above reform efforts, the reduction of the size of the Tanzanian civil service was sought through the rationalization of government employment. Rationalization entailed the retrenchment of non-performers, overdue leavers, and implementation of the voluntary retirement scheme. Retrenchment, perceived as a major way to reduce the size of the Tanzanian CS, was one of the conditions for attaining credit set by the Bretton Woods Institutions. The WB and IMF were of the view that the large number of civil servants was one of the major causes of the country's budgetary imbalances. Accordingly, they recommended that a functional review and an analysis of civil service personnel levels be undertaken. The studies identified and recommended

\footnotetext{
${ }^{482}$ Interview with Mr. Samuel Kiondo, Economist - Regional Administration and Local Government Authorities, Ministry of Finance. held July 4, 2006.

${ }^{483}$ Ntukamazina, D. A. 1998. "Civil Service Performance in Tanzania: A Strategic Perspective.” In Severine M. Rugumamu (ed) Civil Service Reform in Tanzania: Proceedings of the National Symposium. Dar es Salaam: University Consultancy Bureau, p. 51.

${ }^{484}$ Interview with Professor Gelase Mutahaba Chief Technical Advisor, President's Office - Public Service Management, Government of Tanzania, held June 29, 2006.
} 
50,000 civil servants for retrenchment. The actual retrenchment exercise commenced in 1993 and by January 31, 1994, 2,122 poor performers were retrenched from different Ministries. More civil servants from both the central government and local government were let go through the voluntary retirement scheme. At the start of 1995, 47,000 civil servants had been retrenched. In 1997, the civil service staff number had been reduced to 260,000 from 360,000 in 1992 , and the traditional civil service had been reduced to approximately 50,000 personnel. ${ }^{485}$

However, it did not take long for the number of civil servants to start to rise again. The Chief Technical Advisor, President's Office - Public Service Management, revealed that "between the years 2000 to 2004, the number of public servants increased from approximately 263,000 to 286,000 . Most of the increase was in the Ministries of Education, Health and Internal Affairs. Approximately $65 \%$ of all public servants are teachers, doctors, medical officers, nurses, police, or prison officers." ${ }^{486} \mathrm{He}$ revealed further that nearly two thirds - approximately $64 \%$ of all public servants are employed at the local government level but the majority of them are still on the national government wage bill because the decentralization program is not yet complete. Less than $4 \%$ are paid at the local level. Table 7.3 shows the major job classes in the CS.

\footnotetext{
${ }^{485}$ The United Republic of Tanzania, President's Office - Civil Service Department. 1999. Civil Service Reform Programme Implementation Status Report (1993-1999). Dar es Salaam.

${ }^{486}$ Interview with Professor Gelase Mutahaba Chief Technical Advisor, President's Office - Public Service Management, Government of Tanzania, held June 29, 2006.
} 
Table 7.3 Major Job Classes

\begin{tabular}{|c|c|c|}
\hline JOB CLASSIFICATION & NUMBER & $\%$ of TOTAL \\
\hline Teacher & 123,573 & 43.1 \\
\hline Medical Worker (Doctor, Nurse, Medical Officer) & 32,215 & 11.2 \\
\hline Police Officer & 22,309 & 7.8 \\
\hline Education Officer (Inspector, Administrator) & 12,907 & 4.5 \\
\hline Prison Officer & 9,390 & 3.3 \\
\hline Technician/ Craftsman & 7,502 & 2.6 \\
\hline Watchman & 7,397 & 2.6 \\
\hline Office Supervisor/ Attendant & 6,844 & 2.4 \\
\hline Agricultural Field Officer & 4,260 & 1.5 \\
\hline Accountant & 4,168 & 1.5 \\
\hline Driver & 3,338 & 1.2 \\
\hline Livestock Field Officer & 2,915 & 1.0 \\
\hline Typist/ Secretary & 2,868 & 1.0 \\
\hline Village/ Ward/ Division Officer & 2,494 & 0.9 \\
\hline Forest Officer & 2,245 & 0.8 \\
\hline Judicial Officer (Judge, Clerk, etc) & 2,010 & 0.7 \\
\hline Registry Clerk (Records Management) & 1,997 & 0.7 \\
\hline Community Development Officer & 1,600 & 0.6 \\
\hline Kitchen Worker & 1,543 & 0.5 \\
\hline Game Officer & 1,152 & 0.4 \\
\hline Stores/ Supply Officer & 1,125 & 0.4 \\
\hline Public Health Officer & 1,058 & 0.4 \\
\hline Immigration Officer & 753 & 0.3 \\
\hline Telephone Operator & 306 & 0.1 \\
\hline Others & 30,866 & 10.8 \\
\hline TOTAL & 286,817 & 100 \\
\hline
\end{tabular}

Source: United Republic of Tanzania, President's Office - Public Service Management. 2005. State of the Public Service Report 2004. Dar es Salaam, p. 46.

The above table indicates that the teaching sector generates the highest number of government workers. According to the Head of Planning, Budgeting, Monitoring and Evaluation at the Ministry of Education, "between 2000 and 2004, the number of teachers increased by 23,812 . The increase in the number of teachers is roughly equivalent to the net increase in employment in the public service of 23,485 in the same period." ${ }^{487}$ In his view, the teaching service has witnessed a greater need for teachers because of two major

${ }^{487}$ Interview with Mr. Mwaimu, A. S. M., Head, Planning, Budgeting, Monitoring and Evaluation, Ministry of Education, held July 31, 2006. 
programs, namely the Education Sector Development Program (ESDP) and the Primary Education Development Program (PEDP). The Education Sector Development Program covers basic education which includes pre-primary, primary, adult, secondary, teacher education, higher education, and vocational education. The goal of the ESDP is to ensure that the education sector provides equitable and quality education for all Tanzanians. The Primary Education Development Program guides the implementation of free primary education. Evidence shows that the increase in primary school teachers is a direct result of the increase in pupil enrolment. "Enrolment in primary education has been expanding at a fast rate. In 1999 , there were $4,189,816$ pupils and in 2003 , they had increased to $6,562,772$. The net enrolment rate increased from $57.1 \%$ in 1999 to $88.5 \%$ in 2003 . There has also been an increase in gross enrolment rate from $77.1 \%$ in 1999 to 105.3 in 2003." 488 The increase in the size of the Tanzanian CS resulting from the increase in the number of teachers is therefore justified and is in line with the government program to eradicate poverty through literacy.

\subsubsection{The Reduction of the Size of the Tanzanian Civil Service: Rhetoric or Reality?}

The analysis offered above illustrates that at the start of the CSRP in Tanzania, priority was focused on reducing and controlling the size of the civil service. It has been shown that size reduction was achieved through three major way; Organization and Efficiency reviews, personnel control and management, and through rationalization of government employment. The Organization and Efficiency reviews rationalized the

\footnotetext{
${ }^{488}$ The United Republic of Tanzania, Ministry of Education. 2004. Medium Term Strategic Plan, 2004 2007. Dar es Salaam, p. 5.
} 
MDAs roles, functions, and organizational structures by getting rid of the unnecessary ones, merging some, contracting out non-core functions, divesting functions to executive agencies, and by restructuring the local government. The personnel control and management reforms set standards for gaining employment into the CS. An employment policy was put in place and a Public Service Act was passed to guide the employment procedures. Records on employment and staff management are now managed by the Human Capital Management Information System, an initiative that has made it possible to rid the civil service of 'ghost' workers. Rationalization of government employment entailed retrenchment of nonperformers and overdue leavers, and voluntary retirement.

The above efforts generated a big reduction of the civil service size. MDAs were reduced by $25 \%$ and the civil servants from 360,000 in 1993 to 260,000 in 1997 , a $28 \%$ percent decrease. However, by 2000 , the number started to rise as a result of the increasing numbers of staff in service sectors like education and health. The universal primary education program in particular enhanced the need for teachers for primary, secondary, and technical schools. All the study participants commended government effort to offer free basic education and agreed that the increase in the size of the civil service is justified. Figure 7.3 shows the reduction and growth pattern of the Tanzanian civil service from the year 1993 to 2004.

The dramatic decrease in the number of civil servants from 360,000 in 1993 to 260,000 in 1999 is evident in figure 7.3. The gradual increase from 1999 is also apparent. The major goal for reducing the size was to make it smaller, affordable (reduce fiscal pressure), well paid, and efficient. The first aspect has been attained. The rhetoric has been turned to reality - the civil service is smaller. My conclusion is in agreement with 
Clarke and Wood (2001) who assert that the size of the government workforce was considerably reduced. Whether the reduction led to an affordable and well paid service are the subject of the next section and whether it is efficient, will be determined after analysis of the four aspects of the study.

Figure 7.3 Size of the Tanzanian Civil Service, 1993-2004

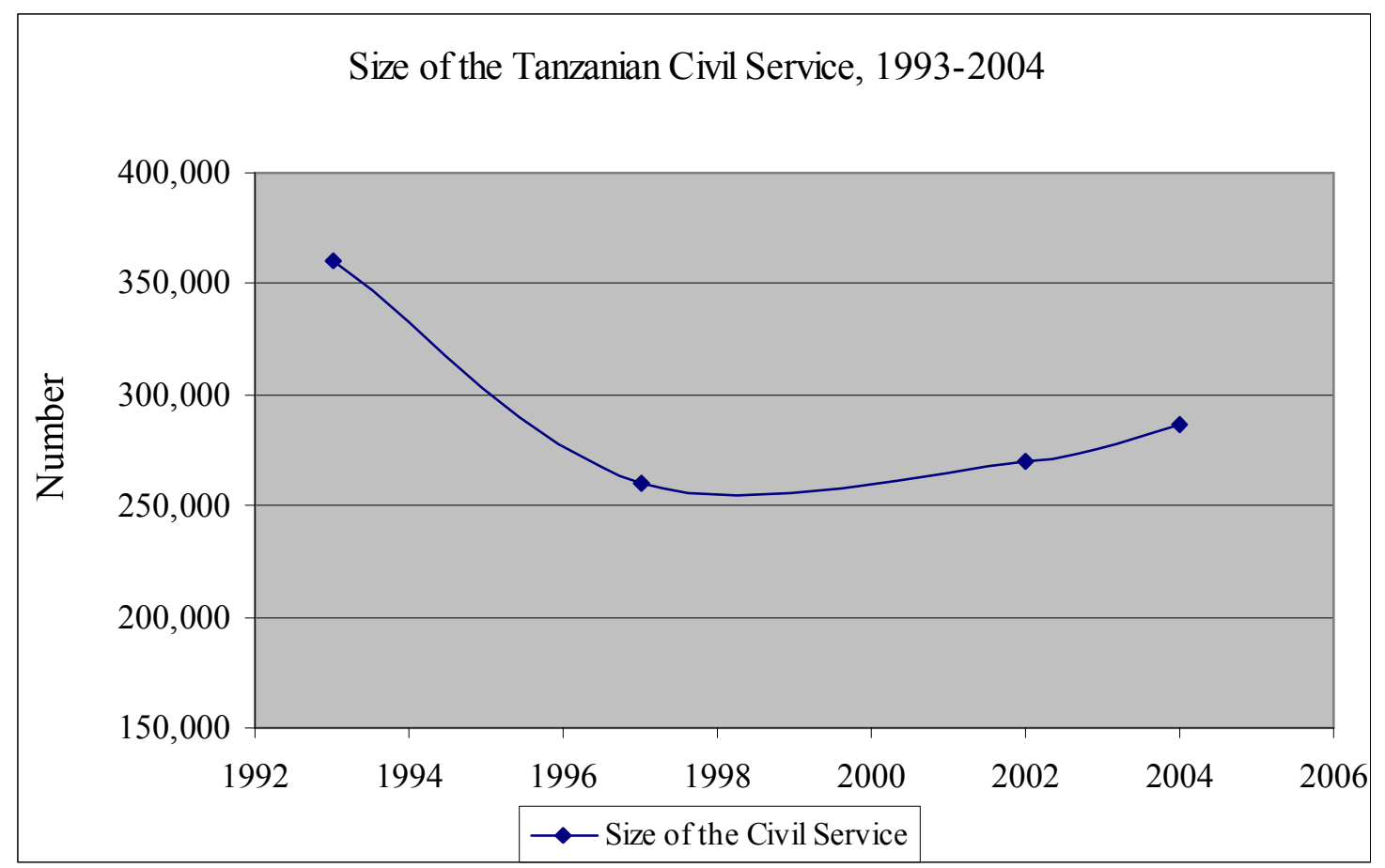

Source: United Republic of Tanzania, President's Office - Public Service Management. 2008. PSRP Phase 1 End of Programme Report: A Summary of Results 2003-2007. Dar es Salalam.

\subsection{PAY REFORM AND THE TANZANIAN CIVIL SERVICE REFORM PROGRAM}

Pay reform is a critical component of the Tanzanian civil service reform program and remains the most challenging. The Tanzanian government placed significant focus on reforming the pay of the civil servants because it was aware that reducing the number of civil servants and government expenditure alone would not generate effectiveness and 
efficiency in performance if the retained workers were not adequately paid and motivated. It should be noted that at independence, the Tanzanian civil service pay was enough to meet the minimum living standards of the employees. The economy was relatively strong, the number of civil servants small, and because the colonial pay policies were not altered. In addition, the difference between the highest paid and lowest paid workers was wide reflecting both experience and educational achievement.

Soon after independence, the civil service under went major changes. The government took on an increasingly leading role in national development that necessitated an increase in the number of civil servants. Africanization of the civil service, an expanding education and health care network, and the self imposed responsibility to offer employment to all that graduated from primary school increased the size of the civil service. The salary structure also witnessed some changes. Salary differentials were reduced in order to make pay scales inherited from the colonial government more egalitarian. African socialism and self-reliance programs adopted in 1967 also changed the civil service as focus was placed on providing a decent income to all citizens irrespective of job classification. "Equity was pursued very vigorously and the differences between the lowest and highest paid employees shrunk very significantly."

For a short time, the post-independence changes worked well. Government employment expanded rapidly, the quest for fast economic development through selfreliant socialism seemed to be on course, education, health care, and clean water were available to the people. However, it was not long before the socialist economic policies

\footnotetext{
${ }^{489}$ Kiragu, K. and Rwekaza Mukandala. 2005. Politics and Tactics in Public Sector Reforms: The Dynamics of Public Service Pay in Africa. Dar es Salaam: Dar es Salaam University Press Ltd.
} 
failed. By the mid 1970s, the economy started to collapse, government employment and expenditure outpaced government revenue, working conditions deteriorated, and pay plummeted. In response to the budgetary pressures, the government carried out staff reductions between 1975 and 1977. The reductions attained proved temporary however. Because the country did not have a viable private sector and other non-government employment alternatives the civil service doors could not be shut for too long. In 1978 the number increased again and by 1984, government employment had grown twice as much as the Gross Domestic Product (GDP). The dwindling domestic revenue, coupled with high inflation made it extremely difficult for the government to adequately cater for basic services and to provide civil servants with adequate working conditions. It is not surprising therefore that the salaries continued to plummet. Figure 7.4 depicts the sharp increase of the size of the civil service in contrast to the stagnating (GDP).

To compensate for the inadequate pay, the government provided a multitude of benefits, subsidies, and allowances to civil servants. Transport, food (breakfast, lunch, tea and snacks), child support (up to four children), housing, medical care, clothing (uniforms), paid leave, and hardship loans were provided. By the mid 1980s, in the majority of the salary scales, the allowances were on average more than $400 \%$ of the basic salary. ${ }^{490}$ Such non-salary benefits caused difficulties in budgetary accountability and transparency, and generated distortions and inequities in the salary structure.

\footnotetext{
${ }^{490}$ United Republic of Tanzania - Civil Service Department. 1999. Civil Service Reform Programme Implementation Status Report (1993 - 1999). Dar es Salaam.
} 
Figure 7.4 Civil Service Expansion and Stagnating GDP, 1970-1984

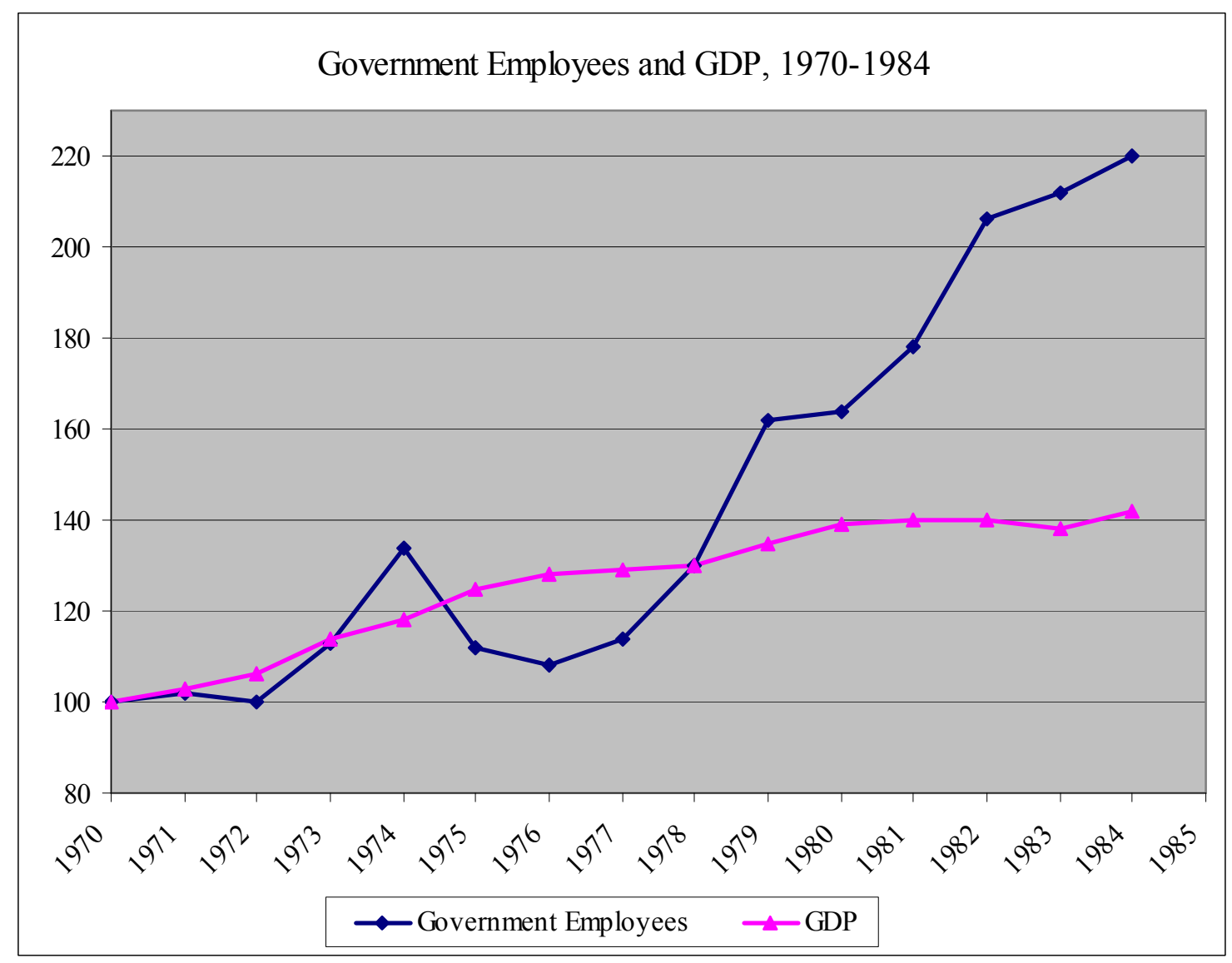

Source: Steven, M. "Public Expenditure and Civil Service Reform in Tanzania." In Rehabilitating Government: Pay and Employment Reforms in Africa. Lindauer, D. L. and Barbara Nunberg (eds.) Washington, D.C: World Bank, p. 66.

In addition, allowances promoted tax evasion since they were tax free thereby denying government the much needed revenue, and since they were not included in the salary structure, civil servants' pension suffered.

In spite of government egalitarian efforts to shore up civil servants' income, a deepening economic crisis generated a sharp decline in government revenues that in turn caused further erosion of salaries. In 1990, it was estimated that the public servants' 
salary level was $25 \%$ of the level paid in $1972 .{ }^{491}$ Poor pay levels and narrow salary differentials had a profound negative effect on performance. Not surprisingly, civil servants lost morale, absenteeism and moonlighting increased, the highly skilled left the civil service for greener pastures, managerial responsibility suffered, and corruption became widespread.

When the government embarked on the IMF/WB driven economic recovery programs in 1986, little attention was paid to the civil service. Kjaer (2004) has asserted that the president at the time, Ali Hassan Mwinyi (1985-1995), focused only on over turning the economic system and disregarded the dire situation the administrative system was in. According to Kjaer, although "Mwinyi was committed to overall economic liberalization, he did not seem determined to introduce longer-term reform of administrative structures. ${ }^{292}$ By 1990, it was evident that the public service lacked the requisite competence to support and implement economic change. One of the major causes of poor CS performance was low pay. When the CSRP was finally initiated, pay reform became a vital part of the reform process. According to the former Permanent Secretary PO-PSM, "it was obvious that the salary structure had become grossly distorted and the pay did not meet the minimum living requirements. The correlation between poor

\footnotetext{
${ }^{491}$ United Republic of Tanzania - Civil Service Department. 1999. Civil Service Reform Programme Implementation Status Report (1993 - 1999). Dar es Salaam.

${ }^{492}$ Kjaer, A. M. 2004. "Old Brooms can Sweep too!: An Overview of Rulers and Public Sector Reforms in Uganda, Tanzania and Kenya." Journal of Modern African Studies, Vol. 42, No.3, p. 399.
} 
pay and poor performance was quite obvious. Pay reform therefore assumed a crucial and integral role in the civil service reform program." 493 The objective of pay reform was:

"to rationalize and enhance civil service pay by eliminating the distortions and anomalies that have crept into the system, and by improving total compensation at all levels so that it meets the minimum household living requirements and is commensurate with the qualifications, skills, experience, and responsibilities of individual civil servants." 494

Evidence from the interviews and documents shows that enhancement of civil servants' salaries has had two phases. The first phase, under President Mwinyi did not generate dramatic changes in pay. With less than two years remaining on his term of office, the president seemed content to let the situation be, and wait for the next leader to take care of it. It was after President Mkapa assumed office in 1995 that major changes began to occur. Figure 7.5 below shows the trend of real civil service pay in Tanzania for the years 1969-1998; salaries were quite high in the period following independence until the mid 1970s when a downward trend ensued. The negative economic growth resulted in the decline in the wage bill. It was not until 1986 that pay increases were put in place and although the trend is not consistent, it is clearly an upward trend. In the period 1993 to 1999, pay reform efforts focused on addressing the structural weaknesses in the grading and salary schemes through two major ways: rationalization of the pay structure which entailed reduction of pay grades and consolidation of the allowances into a basic pay; and, development of an appropriate remuneration system that would enhance the civil

\footnotetext{
${ }^{493}$ Interview with the former Permanent Secretary President's Office - Public Service Management, Mr. Joseph Rugumyamheto, held June 29, 2006.

${ }^{494}$ United Republic of Tanzania - Civil Service Department. 1999. Civil Service Reform Programme Implementation Status Report (1993 - 1999). Dar es Salaam, p. 6
} 
servants' salary. What follows below is an analysis of how they were carried out and to what effect.

Figure 7.5 Real Civil Service Average Pay Trend, 1969-1998.

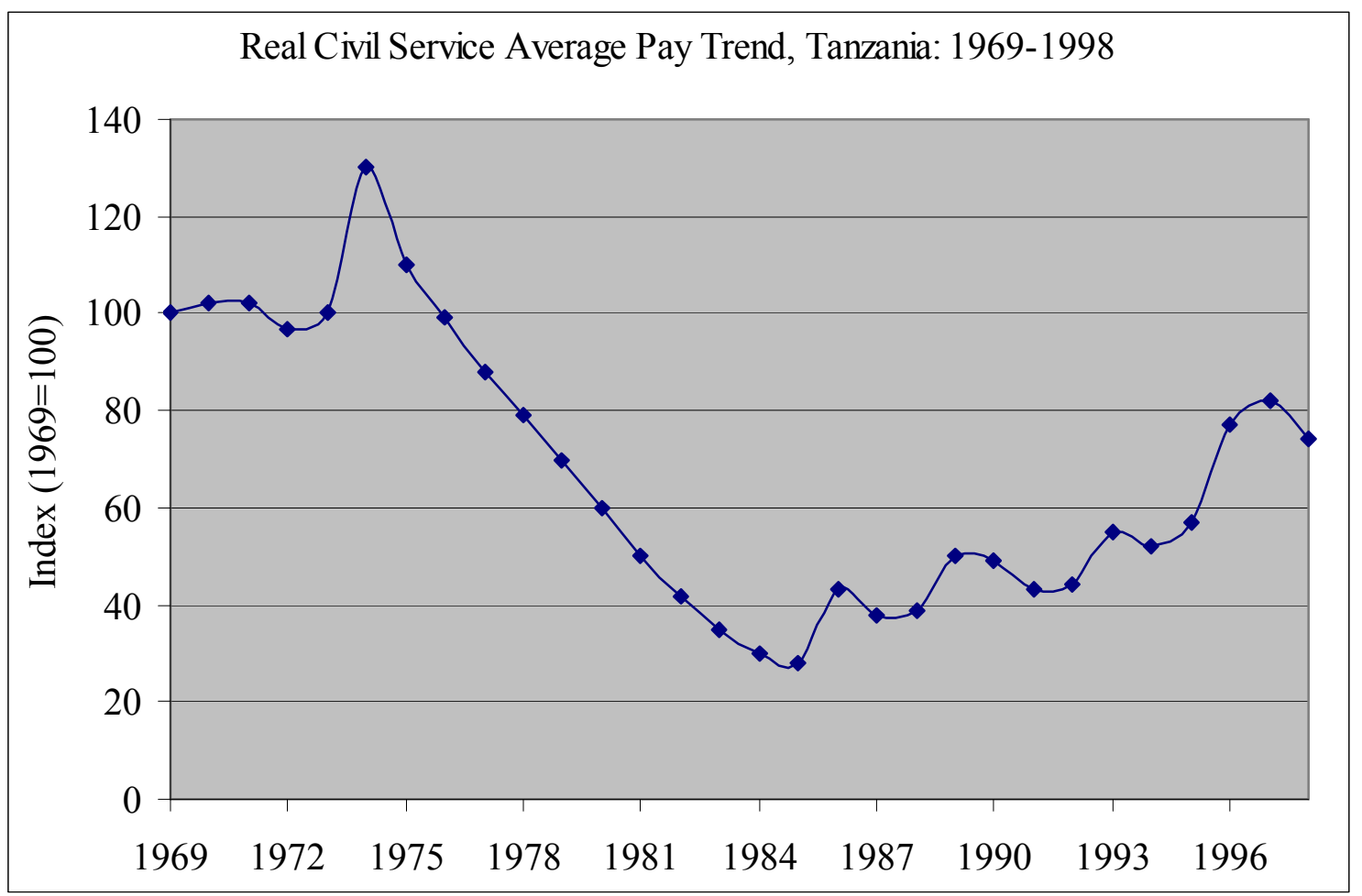

Source: United Republic of Tanzania, President's Office - Public Service Management,. 2005. State of the Public Service Report 2004. Dar es Salaam, p. 52.

\subsubsection{Rationalization of the Pay Structure}

Pay reform efforts were geared towards the rationalization of the pay structure in order to make it transparent, equitable, and efficient. The rationalization process targeted the reduction of pay grades and elimination of allowances. Prior to the reform, there were 
196 pay grades. ${ }^{495}$ The salary structure was highly compressed to the disadvantage of those in the upper grades. In the context of diminishing revenue, salary structure compression was the most practical means through which the Tanzanian government could maintain the offer employment. Kiragu (1998) asserted that in 1969 before the economic downturn, the highest salary earned in the CS was about 30 times higher than the lowest earned salary, but in mid 1980s, the compression ratio was very small at 6 to $1 .^{496}$

It should however be noted that the salary compression effects were not felt by the civil servants equally. Top and high level civil servants diminished the effects by awarding themselves numerous non-cash benefits. It is the technical and professional personnel in the middle level that suffered the brunt of the compressed salary structure. In a comparative salary study carried out in 1996, it was found that for the non-skilled and semi-skilled staff, payment levels were more or less the same in the parastatals, NGOs, and private sector as those in the civil service. For the technical and professional personnel however, payment levels were between two to five times higher in the other sectors than those in the civil service. Table 7.4 below illustrates this disparity.

\footnotetext{
495 Interview Mr. Ramadhani, S. Hamisi, Assistant Commissioner of Budget in the MOF, held July 31 , 2006.

${ }^{496}$ See Kiragu, K. 1998. "Civil Servie Pay Reform Issues and Options.” In Rugumamu, S. (es.) Civil Service Reform in Tanzania: Proceedings of the National Symposium. Dar es Salaam: University Consultancy Bureau.
} 
Table 7.4 Comparative Sector Compensation Levels for Select Job Categories (November 1996)

\begin{tabular}{|l|c|c|c|c|}
\hline Category & Civil Service & Private & Parastatals & NGOs \\
\hline Doctor & $100 \%$ & $240 \%$ & $167 \%$ & $157 \%$ \\
\hline Chief Executive & $100 \%$ & $280 \%$ & $337 \%$ & $362 \%$ \\
\hline Engineer & $100 \%$ & $779 \%$ & $303 \%$ & - \\
\hline Legal Officer & $100 \%$ & $754 \%$ & $398 \%$ & - \\
\hline Accountant & $100 \%$ & $325 \%$ & $251 \%$ & $337 \%$ \\
\hline Economist & $100 \%$ & $878 \%$ & $293 \%$ & $596 \%$ \\
\hline Personnel Officer & $100 \%$ & $637 \%$ & $237 \%$ & $232 \%$ \\
\hline Purchasing/Supplies Officer & $100 \%$ & $310 \%$ & $226 \%$ & $309 \%$ \\
\hline Assistant Engineer & $100 \%$ & $951 \%$ & $186 \%$ & - \\
\hline Technician & $100 \%$ & $284 \%$ & $231 \%$ & $315 \%$ \\
\hline Driver & $100 \%$ & $288 \%$ & $277 \%$ & $216 \%$ \\
\hline
\end{tabular}

Source: Kiragu, K. 1998. "Civil Servie Pay Reform Issues and Options." In Rugumamu, S. (es.) Civil Service Reform in Tanzania: Proceedings of the National Symposium. Dar es Salaam: University Consultancy Bureau, p. 142.

By 1998, the pay grades were reduced to 45 . This reduction helped to decompress the salary structure and generate a larger variation between high and low salary earners within the civil service. The pay disparity between the civil service and other sectors however has not reduced significantly although civil service pay has been increased considerably as shown in the discussion under salary enhancement.

When pay reform was initiated, 36 in-kind and monetary allowances supplemented the civil servants' salary. Monetary allowances constituted approximately $76 \%$ of the total wage bill. ${ }^{497}$ After reform implementation, the allowances, many of which were only offered to senior civil servants in an opaque manner, were reduced to 7 and consolidated into taxable basic pay. The changes reduced the wage bill expenditure.

\footnotetext{
${ }^{497}$ Interview with Interview with Mr. Ramadhani, S. Hamisi, Assistant Commissioner of Budget in the MOF, held August 2006.
} 
In $1994 / 1995$, wage bill expenditures exceeded the budget by $40 \%$ but in $1996 / 1997$ the wage bill was only $2 \%$ over the budget. ${ }^{498}$

Study participants expressed the view that while elimination of allowances made the pay structure more transparent, high level staff suffered higher reductions in their pay because the bulk of their take-home was based on the eliminated allowances. Clarke and Wood (2001) also found that there was an adverse effect on the salary scale of some key professional and middle management personnel due to consolidation of allowances into basic pay. They assert that "recent estimates suggest that real salaries may actually have declined for this group over the period 1995/96 1998/99."499 By the end of 1999 however, benefits like housing assistance and maintenance allowances, and other incidental allowances covered under what is known as "Other Charges Budget" for instance per diems, were brought back into the pay system and are increasingly serving as individual salary supplements. Kiragu and Mukandala (2005) note the same occurrence when they assert that the government is falling back to allowances and the pay reform program is “working in reverse gear." ${ }^{, 500}$ One study participant observed that staff spend a lot of time attending workshops or training regardless of relevance to their duties and careers and vie

\footnotetext{
${ }^{498}$ United Republic of Tanzania, President's Office - Public Service Management. 1999. Civil Service Reform Programme Implementation Status Report (1993-1999). Dar es Salaam, p. 13.

${ }^{499}$ Clarke, J. and David Wood. 2001. "New Public Management and Development: The Case of Public Service Reform in Tanzania and Uganda.” In McCourt, W. and Martin Minogue (eds.) The Internationalization of Public Management: Reinventing the Third World State. Cheltenham, UK: Edward Elgar, p. 73.

${ }^{500}$ Kiragu, K. and Rwekaza Mukandala. 2005. Politics and Tactics in Public Sector Reforms: The Dynamics of Public Service Pay in Africa. Dar es Salaam: Dar es Salaam University Press Ltd, p. 243.
} 
to serve on numerous committees, taskforces, and boards in order to get allowances. ${ }^{501}$ Needless to say, allowances undermine performance because in their pursuit, staff are diverted from their core responsibilities. In order to control the continued growth of allowances, in the financial year 2006/2007, the government capped the proportion of the budgeted resources for incidental allowances.

Table 7.5 below shows the increase in the expenditure on allowances covered under "Other Charges Budget."

Table 7.5 Some Fast Growing Components of the Other Charges Budget

\begin{tabular}{|c|c|c|c|c|}
\hline ITEM & 2001/02 & $2002 / 03$ & 2003/04 & $\%$ INCREASE \\
\hline Utilities & 0.65 & 0.95 & 1.75 & 169 \\
\hline Training - Domestic & 3.58 & 7.00 & 25.22 & 604 \\
\hline Training - Foreign & 0.61 & 3.82 & 3.79 & 521 \\
\hline Sitting Allowances & 0.97 & 1.65 & 4.26 & 339 \\
\hline Per Diem Domestic & 15.00 & 26.70 & 35.7 & 138 \\
\hline Per Diem Foreign & 0.91 & 2.84 & 6.27 & 589 \\
\hline Others & 36.13 & 47.13 & 58.83 & 63 \\
\hline TOTAL & $\mathbf{5 7 . 8 5}$ & 90.09 & 135.82 & 135 \\
\hline
\end{tabular}

Note: all Value in Billions of Tanzanian Shillings

Source: United Republic of Tanzania, President's Office - Public Service Management. 2004. Annual Progress Report 2003/04. Dar es Salaam, pp. 3-15.

The other charges budget is separate from the personal emoluments budget, a technicality that may lead to unfairness and lack of transparency, problems that will surely negate the gains made by trimming allowances at the start of pay reform. In a bid to ensure that does not happen, President Kikwete appointed a taskforce in 2006 to review the issue and

\footnotetext{
${ }^{501}$ Interview with Interview with Mr. Ramadhani, S. Hamisi, Assistant Commissioner of Budget in the MOF, held July 31, 2006.
} 
make appropriate recommendations. The findings of the taskforce were expected to be released in 2007. It is therefore safe to contend that the rationalization of the pay structure by consolidation of pay and monetization of noncash benefits has not yet entirely attained the goal of eliminating allowances to make the pay system equitable, transparent, and efficient.

\subsubsection{Salary Enhancement: Designing an Appropriate Remuneration System}

Although the rationalization of the pay structure is still problematic due to the reemergence of allowances, efforts to increase the civil servants' pay have generated some positive changes. According to the reform reports, a $75 \%$ increase in average civil service real salaries was offered between the years 1993 and 1997. "In nominal terms, average civil service salaries increased from TShs. 12,000 in 1992 to TShs. 54,000 in 1997."502 The cash increase however was not synonymous with an increase in purchasing power especially since inflation levels were still high at $26.6 \%$ in $1996 .{ }^{503}$ It is therefore not surprising that calls for higher pay did not abate.

Major initiatives to enhance remuneration occurred during the implementation of phase one of the Public Service Reform Program (PSRP) initiated in the year 2000. The Government adopted a Medium Term Pay Policy (MTPP) to guide the pay enhancement process and implementation of the policy was guided by a Medium Term Pay Reform Strategy (MTPRS). The strategy consisted of three main elements: the first was the

\footnotetext{
${ }^{502}$ United Republic of Tanzania, President's Office - Public Service Management. 1999. Civil Service Reform Programme Implementation Status Report (1993-1999), Dar es Salaam, p. 13.

${ }^{503}$ United Republic of Tanzania, MOF, 1996/97 Budget.
} 
adoption of a medium term target salary structure that would systematically enhance pay for all public servants. Annual salary adjustment plans were proposed for its achievement. The second element entailed undertaking a Job Evaluation and Re-grading exercise to facilitate improved links between pay and performance. It was anticipated that the exercise would result in improved pay for all staff but most especially for the professional and technical staff. The third element was the adoption of a Selective Accelerated Salary Enhancement (SASE) scheme. The scheme directed salary enhancements to special categories of professional, technical, and managerial personnel thought to be critical to service delivery improvement, those involved in managing the reform process, and those in positions that produce strategic government output. ${ }^{504}$

\section{The Medium Term Target Salary Structure:}

The adoption of a Medium Term Pay Policy (MTPP) with a medium term target salary structure is viewed as one of the major innovations of the pay reform process. Before its adoption, even though the government recognized that civil service pay was low, it would increase pay only by utilizing the residual of the budget after financing sectors like education, roads etc. After the adoption of the MTPP, government committed itself to every year increase the pay of all civil servants by a certain percentage based on the medium pay policy targets. This was a fundamental change that indicated that salary increase would not be dealt with after taking care of everything else in government. It was appreciated that "pay increase is also an important consideration which sits on the

\footnotetext{
${ }^{504}$ United Republic of Tanzania, Public Service Management. 2005. State of the Public Service Report 2004. Dar es Salaam.
} 
table along with other demands in the budget framework, not a residual issue." $" 505$ It was observed that the long term goal of the pay policy is to reach parity in real terms with the pay that the government paid the civil servants in 1976 when it was offering a living wage. $^{506}$

The Medium Term Pay Policy (MTPP) establishes a series of pay targets to increase the civil service pay. In order not to lose focus, the targets are reviewed and updated annually to reflect pay reform experience, and attempts are made to align them closely with levels found in the private sector. Despite the meticulous planning, implementation of the MTPP did not generate immediate tremendous gains. In 2003, it was found that although actual salaries increased, the MTPP targets were not met. Differentials ranged from $13 \%$ in the lower salary grades to $21-32 \%$ in the middle and upper salary grades. The major reason offered for failure to meet the set targets was the increase in the number of teachers and an unexpected reduction in the wage bill/GDP ratio. $^{507}$ The MTPP was based on faulty MTPRS assumptions regarding employment growth and government revenue and expenditure trends. Table 7.6 shows these assumptions. In spite of not meeting the set targets, there is a general view that the MTPP is generating positive changes. It was asserted that within two years of its implementation actual salaries were within 84 to $86 \%$ of their planned levels.

\footnotetext{
${ }^{505}$ Interview with Professor Gelase Mutahaba, Chief Technical Advisor, President's Office - Public Service Management, held June 29, 2006.

506 Ibid.

${ }^{507}$ United Republic of Tanzania. President's Office - Public Service Management. 2004. Public Service Reform Programme Annual Progress Report 2003/04. Dar es Salaam.
} 
Table 7.6 Assumptions in the Medium Term Pay Reform Strategy

\begin{tabular}{|l|c|c|}
\hline ITEM & $\begin{array}{c}\text { MTPRS } \\
\text { ASSUMPTION }\end{array}$ & $\begin{array}{c}\text { ACTUAL } \\
\text { VALUE }\end{array}$ \\
\hline Employment Growth & $-14.70 \%$ & $+5 \%$ \\
\hline Wage Bill/GDP $(01 / 02 ; 02 / 03)$ & $4.6 \% ; 4.7 \%$ & $2.4 \% ; 4.4 \%$ \\
\hline
\end{tabular}

Source: United Republic of Tanzania. President's Office - Public Service Management. 2004. Public Service Reform Programme Annual Progress Report 2003/04. Dar es Salaam, pp. 3-14.

There was a general view that the mere existence of the pay targets and the ability of the government to come consistently close to attaining them should be considered an achievement rather than a failure.

By 2006, more strides were made in salary enhancement. The Chief Technical Advisor President's Office - Public Service Management observed that there have been major improvements in salaries based on the medium term pay targets and the increase is most notable at the lower and middle levels. He asserted that " $74 \%$ of all civil servants now receive salaries in excess of their targets." ${ }^{, 508}$ A 2007 study that used a sample of 34 salary bands also noted that salary targets have largely been met at the lower to middle levels than at upper management levels. It was found that using unweighted averages of the actual to targeted salary levels, "lower bands met their targets by $104 \%$ (TGS A to TGS C), middle bands met their targets by $108 \%$ (TGS D to TGS I), while higher bands met their targets by $67 \%$ (TGS J to TGS Q)., ${ }^{509}$

\footnotetext{
${ }^{508}$ Interview with Professor Gelase Mutahaba, Chief Technical Advisor, President's Office - Public Service Management, held June 29, 2006.

${ }^{509}$ United Republic of Tanzania, President's Office - Public Service Management. 2008. PSRP Phase 1 end of Programme Report: A Summary of Results 2003-2007. Dar es Salaam, p. 32.
} 
Salaries for the Tanzanian civil servants have therefore increased significantly since second phase of reform program was started in the year 2000. While the average gross salary (excluding allowances) during the financial year 2000/2001 was Tanzania Shillings (TShs.) 74,183 , the average salary by $2007 / 2008$ was TShs. 234,000 . This is a total increase of $215.7 \%$ or an average annual compound increase of $17.85 \%$. Once inflation is taken into account, increases remain significant reaching a total of $122.1 \%$ or an average annual compound increase of $12.1 \%{ }^{510}$ Figure 7.6 below shows the average pay levels for the years 2000 to 2008 . Figure 7.6 shows that the salary followed an upward trend especially from the year 2001 and for the next five years increases were sustained. A big jump appeared between 2005 and 2007 showing the commitment to increase pay by the new president who in his inaugural speech said: "I am aware that pay levels in the public service remain a concern. We will look at it. I intend, as soon as possible, to establish a Commission on Public Service Remunerations that I will task to produce short, medium, and long term strategies to improve pay levels and other benefits." ${ }^{, 511}$ At the time of data collection, the Presidential Commission on Pay was undertaking its mandates. Its findings are expected to be the basis for pay reform efforts in the PSRP phase II (2008-2012).

Yet, in spite of the rosy picture painted above, an interview with a professional staff indicated that not everyone is impressed by the achievements. "Our salaries are still

\footnotetext{
${ }^{510}$ Ibid.

${ }^{511}$ President H. E. Jakaya Mrisho Kikwete inauguration address 2005. Cited in United Republic of Tanzania, President's Office - Public Service Management. Public Service Reform Programme Phase II 2008-2012. Dar es Salaam, p. 24.
} 
very very discouraging.... Until the threshold is reached, we can't say there is improvement. People are not happy, motivation is very low"512 a participant observed. There was general agreement that low pay continues to bedevil the reform efforts including capacity building and performance management. Low pay was also cited as the major single factor responsible for the rise in petty corruption.

Figure 7.6 Average Pay Levels (Tanzanian Shillings) 2000 - 2007

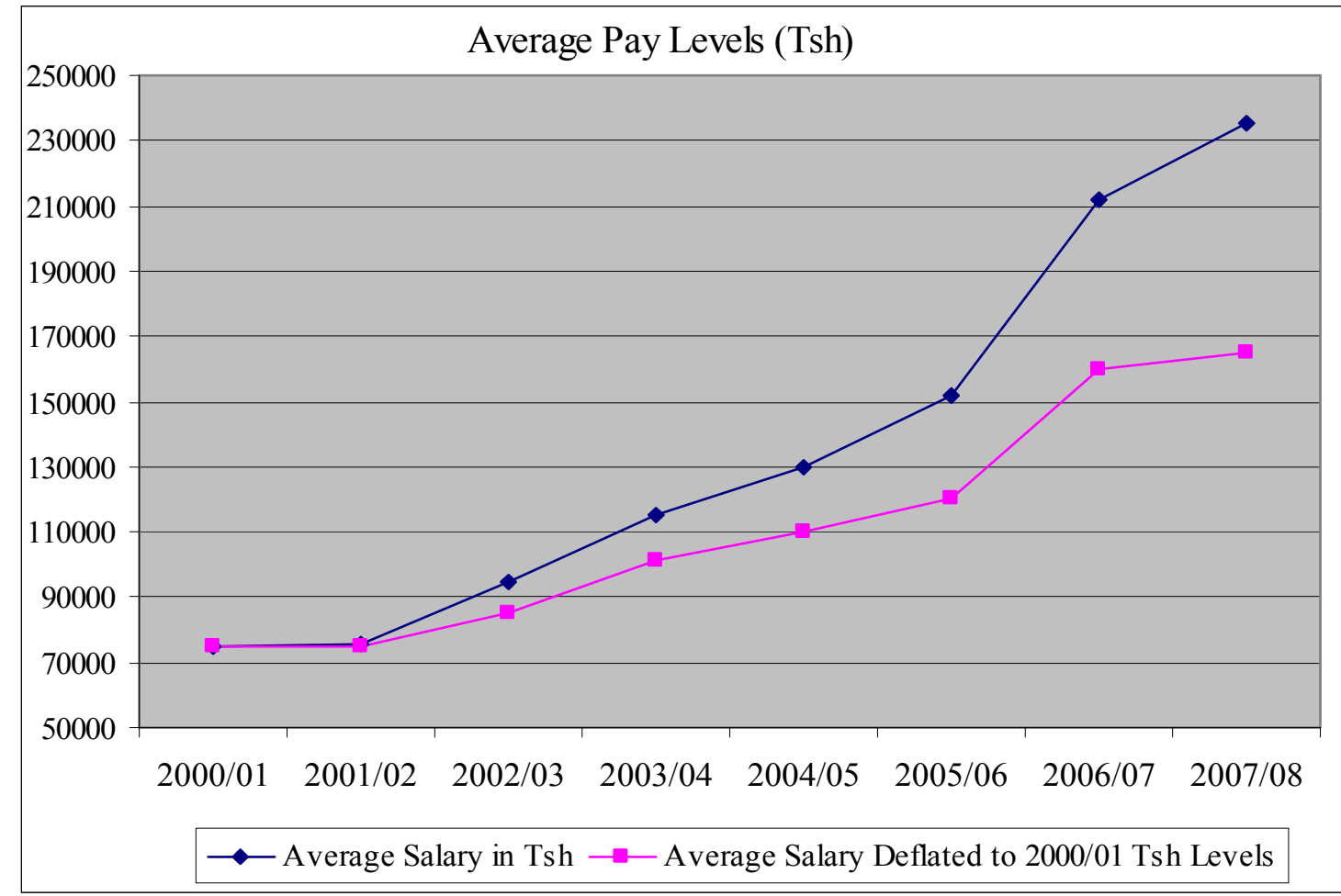

Source: United Republic of Tanzania, President's Office - Public Service Management. 2008. PSRP Phase I end of Programme Report: A Summary of Results 2003-2007. Dar es Salaam, p. 31.

It can therefore be argued that the mechanisms put in place to enhance salary namely the MTPP and the MTPRS have had significant impact. Since the year 2000 the government

\footnotetext{
${ }^{512}$ Interview with Mr. Samuel Kiondo, Economist - Regional Administration and Local Government Authorities, Ministry of Finance, held July 4, 2006.
} 
has remained steady in pursuing pay reform through the medium term target salary structure and some positive changes have been achieved but more still needs to be done. Selective Accelerated Salary Enhancement (SASE):

The Selective Accelerated Salary Enhancement (SASE) scheme was introduced under the MTPRS as an incentive to key public servants in managerial, professional, and technical positions with reform implementation responsibilities. It was also implemented in recognition of the fact that the MTPP targets were not being met. The goal was to give the workers motivation to perform optimally and to retain them in the service. Salary scales under SASE were pegged to target levels contained in the MTPRS and the intention was that in the medium term (six years), donors would on a declining scale finance the gap between current and target salary levels. At its inception, SASE was supposed to cover all the 36 Ministries and Departments. The scheme was linked to performance agreements - Open Performance Review Appraisal System (OPRAS) - in which an individual outlines targets and objectives that will be met in a year and signs a contract with his or her immediate boss. The latter would undertake a mid year and end of year review to assess the performance. Failure to meet the set targets would mean loss of SASE benefits. ${ }^{513}$ Ministries seeking eligibility were required to demonstrate that objective and transparent criteria were used in selecting candidates for SASE and OPRA agreements were signed. However, SASE was implemented in only four ministries; the President's Office - Public Service Management, President's Office - Planning and Privatization, the Ministry of Finance, and the Ministry of Health from the financial years

\footnotetext{
${ }^{513}$ Interview with Mr. Magambo, Nashon, B. S., Commissioner for Budget, Ministry of Finance, held July 31, 2006.
} 
2003/2004 to 2006/2007 following a cabinet decision that ruled against implementation in all 36 ministries.

A study to assess the impact of the SASE scheme on performance and staff retention carried out by Crown Management Consultant in 2005 found that there was strong anecdotal evidence that the scheme had had a significant positive impact on performance of the beneficiaries at both individual and ministerial levels. It was also observed that the MOF and the President's Office - Planning and Privatization, Ministries that had experienced significant turnover of professional and technical staff in the past, indicated that SASE top-ups had assisted in enhancing capacities to attract, retain, and adequately motivate their personnel. ${ }^{514}$

The study participants however observed that SASE was an unfair mechanism of improving pay because it was benefiting only four ministries. It was also asserted that the selection criteria were not transparent because many ministries had met the criteria for selection and yet the scheme was restricted to only four. The selection of benefiting individuals was also identified as one of the shortcomings of the scheme. It was observed that some recipient staff were not bound by OPRAS, some were not critical employees, ${ }^{515}$ and in some instances recipients were about to retire. ${ }^{516}$ It is therefore not surprising that by 2006 , calls for its abandonment were rife. Yet some viewed the scheme as a viable

\footnotetext{
${ }^{514}$ Crown Management Consultatnts. 2005. In United Republic of Tanzania, President's Office - Public Service Management. 2008. PSRP Phase I end of Programme Report: A Summary of Results 2003-2007. Dar es Salaam.

${ }^{515}$ One participant observed that Secretaries received SASE.

${ }^{516}$ Interview with Mr. Magambo, Nashon, B. S., Commissioner for Budget, Ministry of Finance, held July $31,2006$.
} 
transitional strategy to salary enhancement. According to the former Permanent Secretary PO-PSM, SASE has a built in exit strategy which means that once government can meets the medium pay targets, the scheme would be terminated. In his view, it is the legacy of egalitarianism and the general perception that salary enhancement for particular ministries is unfair that have eroded the government's will to continue with the scheme ${ }^{517}$ Ultimately, the scheme was abandoned in the 2007/2008 financial year. The reason offered for its abandonment is that "pay targets were met on the aggregate." 518

\subsubsection{Enhancing Civil Service Remuneration in Tanzania: Rhetoric or Reality?}

The above discussion has shown that the pay reform in the Tanzanian CSRP has been a gradual but steady process. The reform process focused on rationalizing the pay structure and designing appropriate remuneration systems. During the first phase of the CSRP 1993 - 1999, emphasis was place on the rationalization of the pay structure and payroll system. Pay grades were reduced from 196 to 45, allowances from 36 to 7, and a computerized payroll and human resource system was put in place. During the same time frame, civil service real salaries were increased by $75 \%$.

Efforts made in the first phase of the PSRP 2000-2007 generated impressive increases in remuneration. The Medium Term Pay Policy and the Medium Term Pay Reform Strategy are radical innovations that have consistently driven the remuneration

\footnotetext{
${ }^{517}$ Interview with former Permanent Secretary President's office-Public Service Management, Mr. Joseph Rugumyamheto, held June 29, 2006.

${ }^{518}$ United Republic of Tanzania, President's Office - Public Service Management. 2008. PSRP Phase I end of Programme Report: A Summary of Results 2003-2007. Dar es Salaam.
} 
closer to pay targets. Although the progress was slow between 2000 and 2002, the increase after 2003 is quite remarkable (see figure 8.6). However, the adoption of the SASE scheme undermined equity concerns that are still deeply embedded in the Tanzanian social fabric. It therefore proved untenable although enforcement and sustainability concerns contributed to its demise. Over all, there is general agreement that civil service salaries have been enhanced substantially in real terms and the pay structure has been rationalized and simplified.

My findings are in agreement with those expressed by other scholars. Mwapachu (2005) asserted that: "the salaries of public servants, much as they are still lower than those in the neighboring countries such as Kenya and Uganda, have improved a lot." ${ }^{519}$ Similar views were expressed by Kiragu and Mukandala (2005) and Clarke and Wood (2001). Indeed the budgetary trends indicate an increase in the wage bill. For instance between 2000 and 2004 monthly personal emoluments increased from roughly 24 billion shillings to almost 64 billion shillings. This is a $17.3 \%$ increase in shillings equivalent to $9.5 \%$ increase in U.S. dollars. ${ }^{520}$ Yet, the increase in itself is not an indication that salaries were enhanced. The increase in the number of civil servants especially the teachers could account for the rise in the wage bill. Moreover, the wage bill to GDP ratio did not dramatically rise between 2000 and 2004. It was only after the 2004/2005 financial year that an increase was registered. Figure 7.7 below shows that the wage bill to GDP ratio

\footnotetext{
${ }^{519}$ Mwapachu, J. V. 2005. Confronting New Realities: Reflections on Tanzania's Radical Transformation. Dar es Salaam: E\&D Limited, p. 296.

${ }^{520}$ United Republic of Tanzania, President's Office - Public Service Management. 2005. State of the Public Service Report 2004. Dar es Salaam.
} 
remained almost constant until the dramatic increase in $2006 / 2007$ to $5.8 \%$ from $4.8 \%$ in 2005/2006. The increase is attributed to three major factors. First, the new president exhibited his goodwill and prevailed over the MOF to increase allocation to the wage bill. Second, the GDP grew by 6.7 which made it easier for the MOF to mobilize resources for salary enhancement, and third, the increase in the number of civil servants meant an increase in the wage bill.

Figure 7.7 Wage Bill / GDP Ratio 2000-2008.

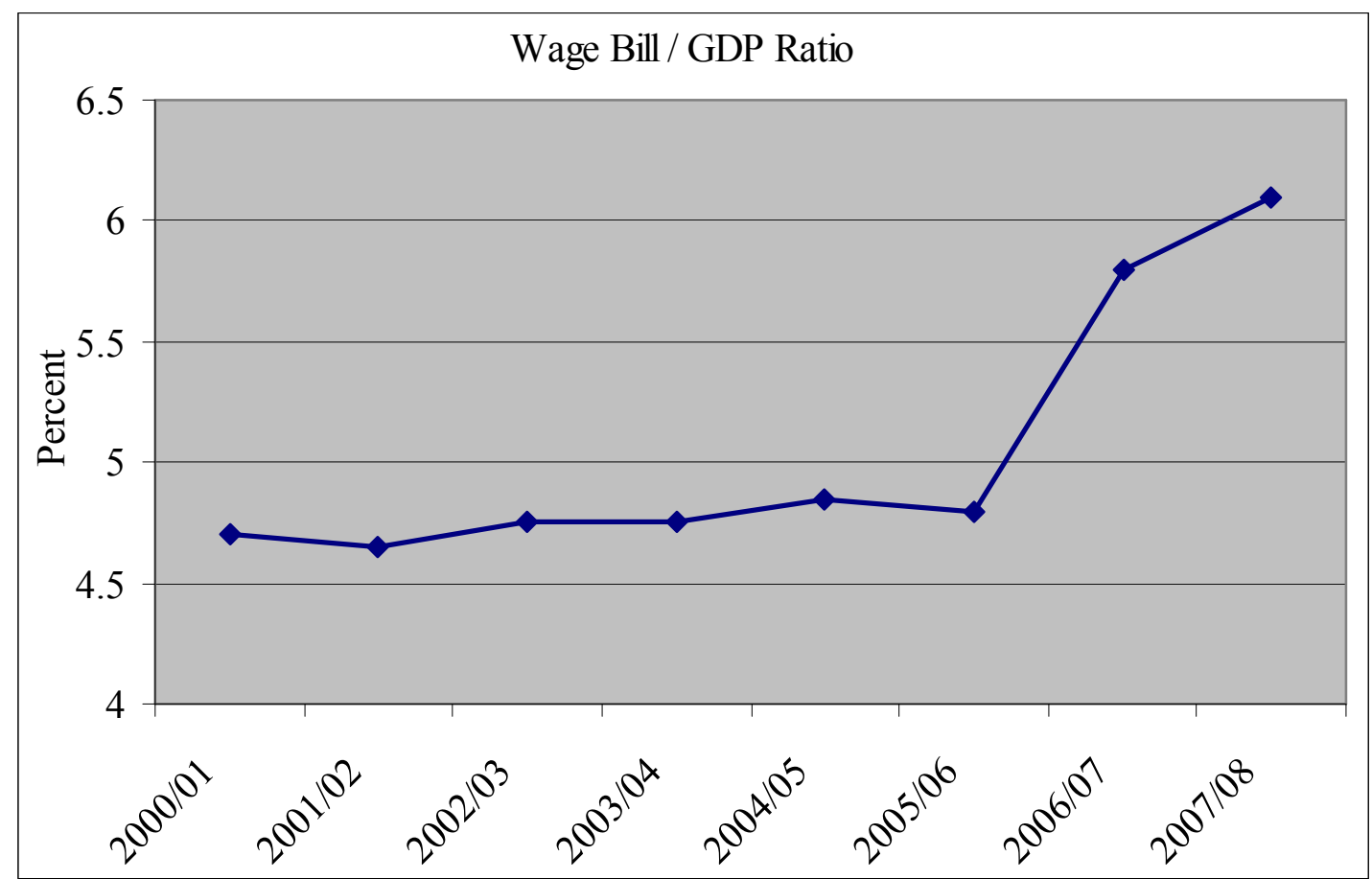

Source: United Republic of Tanzania, President's Office - Public Service Management. 2008. PSRP Phase I end of Programme Report: A Summary of Results 2003-2007. Dar es Salaam, p. 31.

It is my contention that while pay levels have increased the size of the service has also increased. It is therefore not a stretch to assert that the increase in the wage bill/GDP ratio is largely due to the increase in the size of the service rather than enhanced pay levels. 
The analysis offered above showed that the increases in remuneration have not followed the set targets. When implementation of the reform program commenced, it was envisaged that the savings made from reducing the size of the service would be allocated to pay enhancement. However not much was saved partly because government revenues did not increase during the same time period and because an increase in primary school teachers raised the wage bill expenditures. It is therefore not surprising that civil service pay is still considerably less than that offered in the private sector. It has been reported that civil servants' wages are about $39 \%$ of those in the private sector performing similar functions. ${ }^{521}$ Figure 7.8 below shows the civil servants' average salaries as a percentage of private sector average salaries for similar jobs.

The figure strengthens the argument that pay reform in Tanzania has not yet attained the set goal of ensuring that public service salaries are adequate to recruit and retain the best available skills and to ensure that public servants are motivated. The salary of non-skilled workers normally found in the lower pay grades in this case at TGS A, at $78 \%$ is more competitive with that in the private sector than the salary for a middle level officers between TGS D and TGS I. This reinforces the point that the pay reform process has favored more those in the lower pay grades than those in the middle and upper grades. In addition, it can be asserted that in as long as the private sector offers better salaries, the government will run the risk of losing the best skilled staff. It is recognized that the Tanzanian private sector is meager; nonetheless, the risk cannot be underestimated. For instance between 2004-2007, 11\% of civil servants with masters and

\footnotetext{
${ }^{521}$ United Republic of Tanzania, President's Office - Public Service Management. 2008. PSRP Phase I end of Programme Report: A Summary of Results 2003-2007. Dar es Salaam.
} 
doctorate degrees left the service for greener pastures. ${ }^{522}$ While $11 \%$ is a relatively low percentage, approximately $3.5 \%$ per year, it is critical in a country where such qualifications are very hard to come by.

Figure 7.8 Civil Servants' Average Salaries as a Percentage of Private Sector Average Salaries for Similar Jobs in 2006.

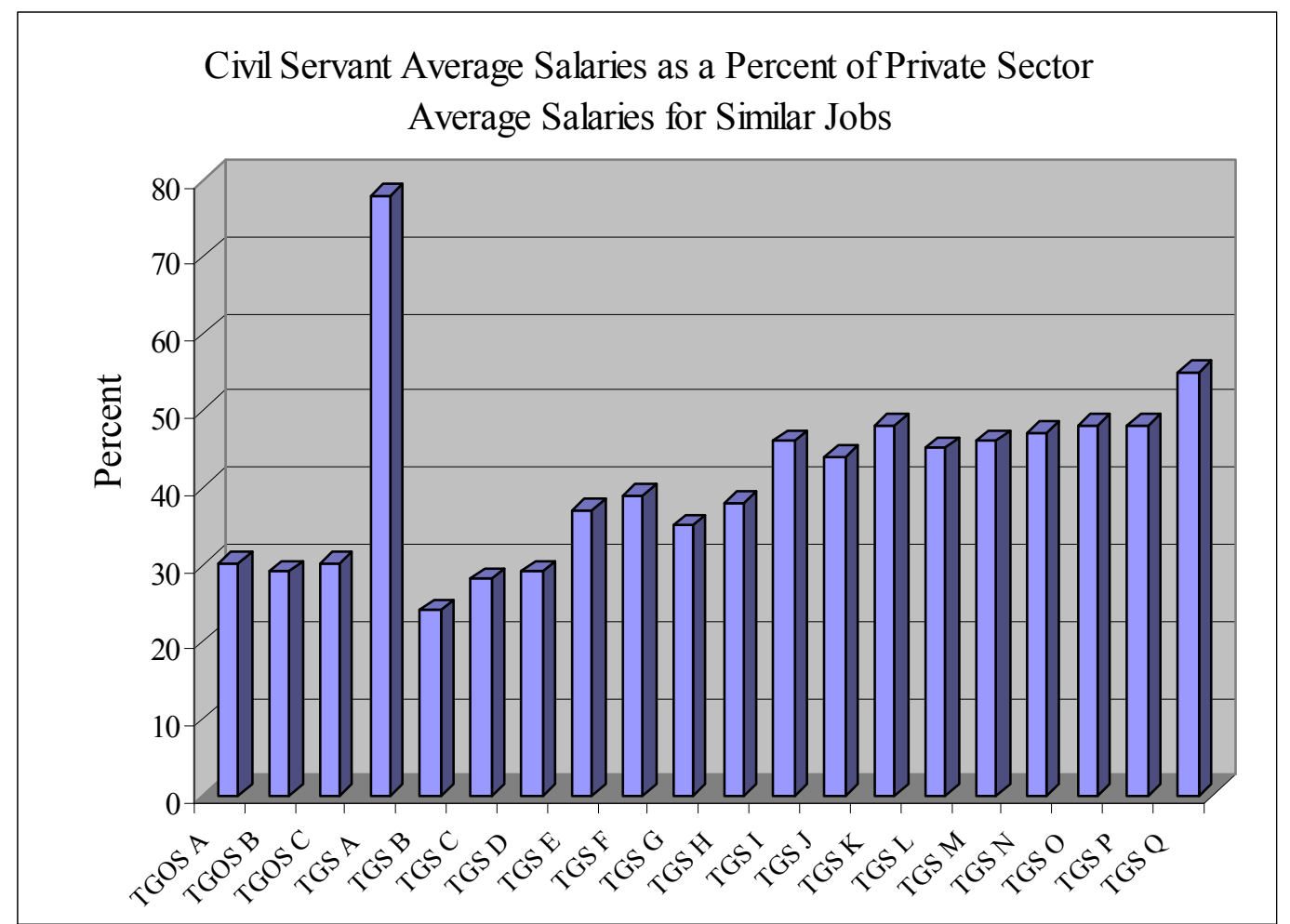

Source: United Republic of Tanzania, President's Office - Public Service Management. 2008. PSRP Phase I end of Programme Report: A Summary of Results 2003-2007. Dar es Salaam, p. 35.

In a nutshell, progress has been made in the rationalization and enhancement of pay in the Tanzanian civil service. The pay reform process is guided by clearly set goals and targets for the medium term and the long term vision is in place. Compared to the

\footnotetext{
${ }^{522}$ United Republic of Tanzania, President's Office - Public Service Management. 2008. PSRP Phase I end of Programme Report: A Summary of Results 2003-2007. Dar es Salaam.
} 
pre-reform period, the civil service is smaller, more affordable and better paid. The rhetoric is becoming reality. Yet, there is general agreement that the success attained has fallen short of the set targets. Civil servants pay remains uncompetitive and below the living wage. Recruitment and retention of qualified and experienced technical and managerial professionals remains precarious. An interviewee put it succinctly: "If you were to ask any civil servant what their major problem is they would say low salaries." ${ }^{, 523}$

\subsection{CAPACITY BUILDING IN THE TANZANIAN CIVIL SERVICE REFORM}

One of the major hindrances to effective and efficient administrative performance is lack of capacity. In 1990, a study commissioned by the United Nations Development Program (UNDP) to assess factors hampering the execution of economic reforms in Tanzania found that the Tanzanian CS lacked the capability to carry out the reforms. The CS had few well trained and qualified staff to oversee and carry out implementation. The lack of capacity is manifested in the civil service census carried out in 1988 which found that approximately $2 \%$ of the civil servants had higher education (diploma and university degree), another 2\% had secondary education at Advanced Level (High school), 24\% had Ordinary Level secondary education (Junior High), and the remaining $72 \%$ had primary education (Elementary school). ${ }^{524}$ Hence, that the majority of the civil servants were carrying out duties and functions for which they lacked or had inadequate skills.

\footnotetext{
${ }^{523}$ Interview with former Permanent Secretary President's Office-Public Service Management, Mr. Joseph Rugumyamheto, held June 29, 2006.

${ }^{524}$ Norwegian Agency for Development Cooperation. 1995. Nordic Initiative for Assistance to Civil Service Reforms, Restructuring and Institutional Development. NORAD, Oslo.
} 
The Structural Adjustment Programs implemented between 1985 and 1990 did not address capacity however. Rather, emphasis was placed on cutting down costs by reducing the scope of government, its size, and budgetary expenditure including personnel costs. Because local capacity was very limited, the WB and IMF relied heavily on foreign expertise to carry out implementation. Mechanisms and institutional arrangements geared towards local capacity and skills development were not devised and budget containment meant that the training budget was starved of resources. According to one participant, "whatever was done was counteracting the capacity building efforts.",525 The budget freeze left many training institutions in decay and some collapsed. Trainers and educators left the country in search of greener pastures. In 1990, rather belatedly, it was realized that without capacity competence reform would not take root. When the CSRP was framed in 1991, capacity building was among the major components.

The Tanzania CSRP emphasized training as the mainstay of capacity building. A draft civil service training policy was to be developed to provide guidelines for all capacity building initiatives. It was anticipated that by 1996, it would be ready for Cabinet approval. By the end of 1999 however, the policy was still in draft form. This is because the CSRP phase (1993-1999) focused on cost-containment and reduction of the size of the CS and did not give much attention to the development of the civil servants' competence. Indeed implementation relied heavily on foreign expertise with minimal local personnel contribution. It should however be noted that some training was offered for the high level officials. For instance, training in the Management of Change was

\footnotetext{
${ }^{525}$ Interview with former Permanent Secretary President's Office - Public Service Management, Mr. Joseph Rugumyamheto, held June 29, 2006.
} 
offered to Directors in the Civil Service Department and Administration and Personnel in the different Ministries by the UK Civil Service College. Permanent Secretaries and Ministers were also offered training in Strategic Leadership and Change Management. In addition, a workshop on the management of training was conducted for 26 training officers from the civil service in early 1996, and 295 civil servants were offered training in reform interventions and change management, basic computing skills, and time management. $^{526}$ Nonetheless, these efforts were not sufficient to carry forward implementation of the reform program. It was left to the second phase of the reform, the PSRP 2000 - 2007, to pay the needed attention to civil service capacity development.

\subsubsection{Public Service Reform 2000 - 2007 and Capacity Building}

During the second phase of the administrative reforms, capacity building efforts were placed on strengthening leadership management capacities and staff development. The two components had the following planned targets: undertaking a survey of training needs assessment in all MDAs; preparing Staff Development Plans in MDAs; training civil servants in Leadership, Management, and Customer Service; implementing the Civil Service Training Policy; and enhancing the capacities of the Tanzania Public Service College (TPSC), and the Tanzania Global Distance Learning Centre (TGDLC). The goal was to develop the skills of the civil servants and to instill in them attitudinal and behavioral change.

\footnotetext{
${ }^{526}$ United Republic of Tanzania, President's Office - Civil Service Department. 1999. Civil Service Reform Programme: Implementation Status Report (1993 - 1999). Dar es Salaam.
} 
The study found that modest progress was made in meeting the above targets. The training Needs Assessment Survey, conducted by the PO-PSM was in 2006 completed in only 10 MDAs $^{527}$ With the realization that in-house assessment might be more fruitful, responsibility to carry out the assessment was handed over to the MDAs. As of June 2008, it was not clear how many MDAs had completed the assessments. ${ }^{528}$ Moreover, the training policy, which was originally supposed to be approved by cabinet in 1996, was in 2006 still incomplete.

Human Resource Staff Development Plans were to be prepared by all MDAs with facilitation from the PO-PSM. In the summer of 2006, preparation was completed in only 5 MDAs. ${ }^{529}$ The PO-PSM later that year relinquished all the responsibility for preparation to the MDAs. The latter were supposed to assess their training gaps, create their own training selection criteria, train and monitor their training impact. If any plans have since been developed, it is not clear which MDAs have prepared them and the quality and implementation of the plans is not monitored. ${ }^{530}$

The training of civil servants in different short term and long term career development areas important to performance improvement was offered by PO-PSM. Courses were offered in such areas as Leadership, Customer Care, Information

\footnotetext{
${ }^{527}$ Interview with Professor Gelase Mutahaba Chief Technical Advisor, President's Office - Public Service Management, held June 29, 2006. In 2006 there were 24 Ministries, 14 Departments and 2 Agencies.

${ }^{528}$ United Republic of Tanzania, President's Office - Public Service Management. 2008. PSRP Phase 1 End of Programme Report: A Summary of Results 2003 - 2007. Dar es Salaam.

${ }^{529}$ Interview with Professor Gelase Mutahaba Chief Technical Advisor, President's Office - Public Service Management, held June 29, 2006.

${ }^{530}$ United Republic of Tanzania, President's Office - Public Service Management. 2008. PSRP Phase 1 End of Programme Report: A Summary of Results 2003 - 2007. Dar es Salaam.
} 
Communication Technology (ICT), and Open Performance Review Appraisal System (OPRAS). By 2006, training was offered to 5,122 civil servants. Between 2006 and 2008 an additional 2,079 staff received training bringing the total to 7,201 , roughly $6.85 \%$ civil servants. ${ }^{531}$ Table 7.7 below shows the training offered.

Table 7.7 Training Supplied by PO-PSM

\begin{tabular}{|c|c|c|c|c|c|c|c|}
\hline TRAINING & $2002 / 03$ & $2003 / 04$ & $2004 / 05$ & $2005 / 06$ & $2006 / 07$ & $2007 / 08$ & TOTAL \\
\hline OPRAS & - & - & 900 & 615 & 1,179 & - & 2,694 \\
\hline Leadership & - & 61 & 361 & 129 & 202 & - & 753 \\
\hline ICT & - & 24 & 420 & 100 & 108 & - & 652 \\
\hline Other & 185 & 578 & 680 & 1,069 & 337 & 253 & 2,664 \\
\hline TOTAL & 185 & 663 & 2,361 & 1,913 & 1,826 & 253 & 7,201 \\
\hline
\end{tabular}

Source: United Republic of Tanzania, President's Office - Public Service Management. 2008. PSRP Phase 1 End of Programme Report: A Summary of Results 2003 - 2007. Dar es Salaam, p. 39.

The study participants were in agreement that the training was useful to job performance. It was asserted that different thought processes have been developed leading to a positive change in mindset and attitudes. It was also asserted that training has generated the awareness that to attain effective performance, emphasis must not only be placed on inputs but outputs and outcomes as well. ${ }^{532}$

Because the training policy is not yet operationalized, the training has not been undertaken systematically in Tanzania. It was found that there are some weaknesses and lack of transparency in the criteria for selection of those to undertake training. For

\footnotetext{
${ }^{531}$ United Republic of Tanzania, President's Office - Public Service Management. 2008. PSRP Phase 1 End of Programme Report: A Summary of Results 2003 - 2007. Dar es Salaam.

${ }^{532}$ Interview with Mr. Nassor Mnambila, Assistant Director, Ethics Promotion Department, held July 4, 2006.
} 
instance training was offered to some nearing retirement age, while in some cases training was not useful to the trainee's job description. Failure to complete the training needs assessment has also made planning the courses and the selection of participants more incoherent.

The pursuit of training by civil servants was found to be influenced by getting allowances than knowledge acquisition. It was found that while workshops, seminars, and conferences enhance capacity building, many of them are viewed as an avenue for indirect salary supplement. To some participants, workshops and seminars have reached a saturation point and negate capacity building as civil servants spend a lot of time away from their daily duties. ${ }^{533}$

National training capability was strengthened by establishing a Public Service College to operate as an executive agency in charge of offering training and refresher courses to civil servants. In addition, the Tanzania Global Distance Learning Center was inaugurated in 2000 to enhance acquisition of current knowledge and skills in a cost effective and flexible manner without incurring costs for overseas training. Performance of both institutions has increased; enrollment rates have risen, more courses are being offered, and revenue has gone up. Some of the courses offered to civil servants include Ethics, Finance and Procurement, Human Resources Management, and ICT. ICT and management information systems capacity have improved in all MDAs. Most of them have modern web-sites and are equipped with computers, while seven MDAs have standalone management information systems departments.

\footnotetext{
${ }^{533}$ Interview with Professor Gelase Mutahaba Chief Technical Advisor, President's Office - Public Service Management, held June 29, 2006.
} 


\subsubsection{Capacity Building in the Tanzanian CSRP: Rhetoric or Reality?}

The analysis offered above shows that few of the targets for capacity building have been met. Capacity building in the Tanzania CSRP aimed at increasing the skills and competency of civil servants so as to improve performance. Although some participants indicated that training resulted in enhanced knowledge and skills, and viable application of knowledge to duties and functions, lack of a training policy and failure to complete the training needs assessment exercise cast the applicability of the training in doubt. Without a training needs assessment to use as a benchmark, it becomes difficult to ascertain whether the civil servants are getting the right training and becoming more competent. The Chief Technical Advisor to the reform program provided an overall verdict when he observed that capacity building efforts have been very slow; "we have not done very well in this area. We are trying but we have not really had a purposeful effort." ${ }^{, 534}$ At this point therefore, capacity building is still more rhetoric than reality.

\subsection{ETHICS AND ACCOUNTABILITY IN THE TANZANIAN CSRP}

Ethics, accountability, transparency, and integrity are essential elements of administrative institutions and processes. The ethical stance of public officials especially the civil servants, and the availability of, and abidance by accountability mechanisms and codes of conduct all have significant impact on civil service performance. The economic stagnation and administrative inefficiency of the 1970s and 80s led to gross decline in ethics and accountability in the Tanzanian CS. Mismanagement, corruption,

\footnotetext{
${ }^{534}$ Interview with Professor Gelase Mutahaba Chief Technical Advisor, President's Office - Public Service Management, held June 29, 2006.
} 
embezzlement of funds, and disregard for civil service rules and regulations became the norm as CS performance degenerated to low levels and service delivery all but ceased. Yet, in spite of this dire state, ethics and accountability were not given attention at the inception of the CSRP. Indeed, between 1990 and 1995, government efforts to deal with corruption and lack of accountability were largely ineffective. Formulated outside the CSRP framework, they mainly consisted of anti corruption squads which emphasized enforcement while ignoring the context that fostered unethical behavior.

It was not until January 1996 after President Mkapa assumed office that ethics and accountability gained prominence in the reform rhetoric and a strong determination to fight corruption in government ensued. The President appointed a special Commission to investigate corruption in government which in December 1996 reported that corruption was rampant in all sectors of the economy, public services, and the politics in the country. According to the report, corruption was widespread in the civil service because of low wages and poor benefits. Civil servants, dissatisfied with their working conditions, resorted to bribes, embezzlement, and other unethical means of income generation. The Commission believed that the situation could be improved if better salaries and wages were offered. ${ }^{535}$

At the launch of the PSRP in June 2000, President Mkapa proclaimed that the country was at a threshold of a new era of national prosperity and honor that demanded a transformed public service. He asserted that such a service would be "truly transparent and accountable to the public. The service will have zero-tolerance for corrupt

\footnotetext{
${ }^{535}$ Presidential Commission of Inquiry against Corruption. 1996.
} 
behavior." 536 Ethics and accountability were therefore included in the PSRP with the objective of "reinstating ethical conduct through inculcation of values and standards of performance to public servants." 537 It was anticipated that by 2005 , a strong Ethics Division would be in existence at the Civil Service Department, capacity for ethics management would be established in MDAs, citizen involvement in public service accountability would be enhanced, and public servants would be more ethical and accountable.

\section{The Ethics Division:}

An ethics division was formed and charged with promoting ethical behavior within the public service in conjunction with other watchdog bodies like the Prevention of Corruption Bureau (PCB) and the Good Governance Coordination Unit (GGCU). The Division is responsible for building internal capacity of MDAs, enabling them to undertake ethics monitoring, inspection, and enforcement. Between 2000 and 2004, it focused attention on policy and regulation formulation, capacity building, and awareness creation efforts. It developed a Public Service Code of Ethics and Conduct that was widely disseminated in all MDAs. A complaints handling strategy operational manual for MDAs was also designed to facilitate the handling of internal and public complaints. All the study participants were familiar with the code and asserted that it was helpful in specifying the areas that are pertinent to ethical performance and in offering guidelines for dealing with ethical dilemmas.

\footnotetext{
${ }^{536}$ New Utumishi, Journal of the Tanzania Public Service Reform Programme, p. 1.

${ }^{537}$ United Republic of Tanzania, President's Office - Civil Service Department. 1999. Civil Service Reform Programme Implementation Status Report (1993 - 1999), Dar es Salaam, p. 29.
} 
Capacity for Ethics Management in MDAs:

The Ethics Secretariat has offered various training programs to build the capacity of MDAs to enable them to monitor ethics and accountability of the public servants. Training of trainers courses in public service ethics have been offered to more than 200 trainers from different Ministries. Those trained are available to continuously train members of their Ministries in public service ethics. ${ }^{538}$ Subjects covered in the training include accountability, transparency, conflict of interest, diligence and competency, confidentiality, fairness and impartiality, integrity and honesty, codes of conduct, corruption, its causes, effects, and strategies to combat it among others. To better handle ethics complaints and address ethics issues within the MDAs, the latter were supposed to form ethics committees. However this has not been done. This failure is a major shortcoming of the efforts to enhance ethics and accountability because the committees are not only supposed to help in the monitoring and detection of unethical practices of corrupt public servants within the MDAs, but, are also supposed to handle internal complaints and those from the public.

\section{Enhancing Public Awareness:}

A wide range of activities have been undertaken to raise civil society awareness about public service ethics and accountability. It is recognized that an informed and vigilant public can be a vital resource in combating unethical tendencies like corruption. Radio and television programs have been aired; newspaper articles and booklets published, and visual aids like posters have been widely displayed calling on the general

\footnotetext{
${ }^{538}$ Interview with Mr. Nassor Mnambila, Assistant Director, Ethics Promotion Department, held July 4, 2006.
} 
public to embrace the responsibility of holding public servants accountable. Table 7.8 shows the ethics awareness campaigns that have been undertaken.

\section{Table 7.8 Ethics Awareness Highlights}

\begin{tabular}{|l|c|c|c|c|c|}
\hline EVENT & $\mathbf{2 0 0 3 / 0 4}$ & $\mathbf{2 0 0 4} / \mathbf{0 5}$ & $\mathbf{2 0 0 5 / 0 6}$ & $\mathbf{2 0 0 6 / 0 7}$ & TOTAL \\
\hline Radio Programmes & 104 & 104 & 104 & - & 312 \\
\hline Television Programmes & 0 & 12 & 24 & - & 36 \\
\hline Newspaper Articles & 104 & 104 & 104 & - & 312 \\
\hline Posters & - & - & 20,000 & 5,000 & 25,000 \\
\hline Various Booklets & - & - & 50,000 & 50,500 & 105,000 \\
\hline
\end{tabular}

Source: United Republic of Tanzania. President's Office - Public Service Management. 2008. PSRP Phase 1 End of Programme Report: A Summary of Results 2003-2007. Dar es Salaam, p. 44.

The study participants considered radio and news papers awareness programs in English and Kiswahili essential in raising awareness because the two mediums of communication reach a large portion of the population. Posters on big roadside boards were visible on major highways in Dar es Salaam but study participants indicated that the visibility decreased the further away from the city one went. There was general agreement that the public is becoming increasingly aware and intolerant of unethical behavior. It was indicated that since 2002 public complaints about unethical behavior have increased by about 11 percent per quarter. However, because the Ministerial ethics committees are not operational, such complaints are not being addressed promptly. ${ }^{539}$

To hold public servants accountable, the PSRP in 2001 instituted Client Service Charters (CSCs) and Open Performance Reviews and Appraisals (OPRAS) in MDAs.

\footnotetext{
${ }^{539}$ Interview with Mr. Nassor Mnambila, Assistant Director, Ethics Promotion Department, held July 4, 2006.
} 
CSCs are social pacts between service providers and the recipients specifying standards of service delivery in the form of commitments or promises. They are supposed to enhance customer service and commit public servants to meet their targets. In 2004, a study to assess the degree to which commitments in the charters were being met was undertaken by the PO-PSM office in five Ministries and two Executive Agencies. 72 commitments were evaluated and a sample of 20 instances of actual service delivery for each commitment was made for the years 2001-2004. It was found that commitments were met $60 \%$ of the time and performance ranged from $31 \%$ to $81 \%$. However, on assessing the performance before and after the charters were put in place, it was found that commitments were likely to be met $64 \%$ of the time prior to the charters and $60 \%$ post the charters. It was therefore concluded that the charters had not had any significant positive impact on service delivery. ${ }^{540}$

In the same study, it was found that $35 \%$ of the service users had complained about the public servants' performance with $33 \%$ asserting that public servants were corrupt. However, $1 \%$ were satisfied with the responses they received while $59 \%$ were dissatisfied and $21 \%$ were very dissatisfied with the way their complaints were handled. ${ }^{541}$ It can therefore be argued that although using client charters is a good innovation, it has not enhanced performance and accountability. Moreover, government commitment to enhance accountability remains in doubt because in spite of the high

\footnotetext{
${ }^{540}$ United Republic of Tanzania, President's Office - Public Service Management. 2005. State of the Public Service Report 2004. Dar es Salaam.

${ }^{541}$ United Republic of Tanzania, President's Office - Public Service Management. 2005. State of the Public Service Report 2004. Dar es Salaam.
} 
levels of dissatisfaction, few public servants are punished for violating rules and regulations. It was revealed that government is taking a more strict stance in dealing with the corrupt and those that do not abide by accountability standards. However, evidence shows only a mild increase in suspension of public servants found in violation of rules. Figure 7.9 shows the number of suspensions effected between 2000 and 2007.

Figure 7.9 Number of Suspended Public Servants per 100,000 Public Servants.

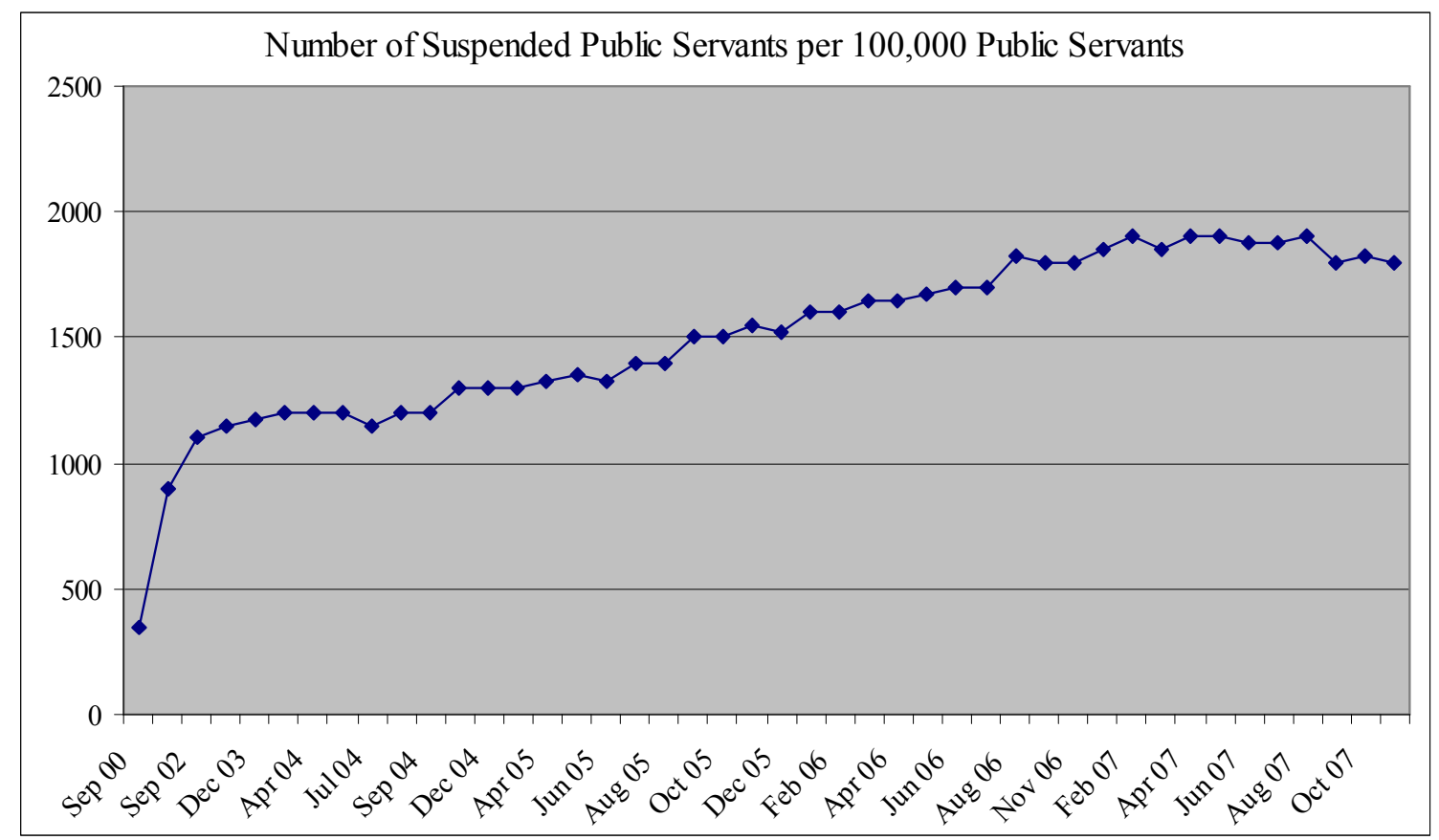

Source: United Republic of Tanzania. President's Office - Public Service Management. 2008. PSRP Phase 1 End of Programme Report: A Summary of Results 2003-2007, Dar es Salaam, p. 10.

Figure 7.9 shows that the number of suspensions increased from less than 500 in 2000 to more than 1000 in 2003 but thereafter the rate stayed almost constant. Renewed efforts to enhance public service ethics and accountability exhibited by the new President and donor support for anti corruption programs might explain the slight increase that has occurred since 2006 . 
Open Performance Reviews and Appraisals is an innovation through which accountability is supposed to be enhanced. At the beginning of each financial year subordinates and their superiors agree upon the work targets and objectives to be met, agree to review progress mid-year and to make an end of year assessment of objective achievement. The reveiw process was thought to enhance accountability because both parties would be involved in setting goals and objectives and in discussing evaluation results. It was however revealed that while performance agreements are being made and OPRA forms filled on a routine basis, progress is not monitored and reviewed. "Open performance assessment had not taken root. It is very hard to implement and not much progress has been made. Public servants find it cumbersome and time consuming and some even think it is irrelevant." ${ }^{, 542}$ It can therefore be asserted that OPRAS have not yet attained the goal of enhancing administrative accountability.

In order for client charters and OPRAS to be effective, the performance has to be monitored closely to ensure that commitments are being met. Such monitoring requires a rigorous system that is firmly built in the Ministry's daily operations and a management that is committed to its implementation. So far, both are lacking. Where complaints are raised whether from the public or from within the Ministry, they should be addressed promptly. The effectiveness of handling complaints however will largely depend on the existence and integrity of ethics committees and the officers/management addressing the complaints.

\footnotetext{
${ }^{542}$ Interview with Mr. Magambo, Nashon, B. S., Commissioner Budget, Ministry of Finance, held July 31, 2006.
} 
In addition to the reform efforts undertaken within the PSRP framework, the government of Tanzania has since 1995 reenergized its efforts to fight corruption and enhance public service ethics and accountability. Some of the initiatives taken include the formulation of the Public Leadership Code; enactment of the National Anti-corruption Strategy and Action Plan; and the revitalization of the preexisting institutions like the Prevention of Corruption Bureau.

The Public Leadership Code:

President Mkapa approved the Public Leadership Code of Ethics Act No. 13 in 1995 to promote ethical behavior in government. It emphasizes the role of transparency and integrity in restoring public confidence in government and strengthening national ethics. The code requires cabinet ministers and senior public servants to annually disclose their property and sign a code of ethics declaring that assets acquired during their tenure in office will be attributable to their legal income. It was asserted that the president set a good precedent by declaring his assets within days of assuming office a trend that is being steadily embraced by those in public office. ${ }^{543}$ However, enforcement of the code is still a challenge. There was general agreement that some public officers have not declared their wealth and non compliance has not been met with strict repercussions. Moreover, the general public does not have access to declarations making it difficult to hold those that have not declared their assets accountable. Ultimately, the effectiveness of the code will depend on long term compliance with its provisions otherwise public officers will find it easy to use public office for self aggrandizement.

\footnotetext{
${ }^{543}$ Interview with Prof. Gelase Mutahaba, Chief Technical Adviser, Public Service Reform Program, held June 29, 2006.
} 
The National Anti-corruption Strategy and Action Plan (NACSAP):

One of the major manifestations of unethical behavior and lack of accountability is the presence of corruption in government. It is therefore not surprising that efforts to enhance ethics and accountability have placed great focus on curbing corruption. The Commission of inquiry into corruption in Tanzania that was appointed by President Mkapa soon after he assumed power made various recommendations on how to deal with corruption. Among them was the establishment of a national anti-corruption strategy and action plan. The strategy that was launched in 2000 embodies the government's efforts to curb corruption and focuses on seven major areas: the rule of law and legal framework; financial discipline and management; procurement; public education awareness and sensitization of the public rights; public service reform; whistle blowers and witness protection; and the media. It provides a framework for dealing with corruption in government be it petty or large scale. It also provides guidelines for MDAs to initiate concrete measures for corruption prevention, enforcement of rules and regulations, and avenues to increase public awareness and involvement of watchdog institutions.

The NACSAP is implemented by the Good Governance Coordination Unit (GGCU) in the President's Office. The GGCU monitors implementation of crosscutting reforms geared towards corruption prevention and rallies MDAs to regularly provide reports about their efforts against corruption. Because of this drive, MDAs are now in the process of developing and implementing sectoral anti-corruption action plans. One of the major achievements of NACSAP is the passing of the Public Procurement Act in 2004. It was asserted that prior to the reform government procurement was corruption and embezzlement ridden. "There was no clear procurement process; no transparency in the 
use of public funds and in purchases; there was a lot of abuse. We now have a legal instrument that has professionalized procurement and saved government a lot of money., 544

There was a general consensus that NACSAP initiatives have generated greater zeal to fight corruption in the government. Yet there also was a general agreement that corruption is still prevalent in the public service although it was not clearly indicated that it is on the rise or major decline. Many of the study participants had the perception that there is a slight decrease in corruption especially petty corruption because it is easier to detect and punish. There was also a general view that the increase in remuneration and improvement of procurement procedures had reduced incidences of corruption. That corruption is decreasing seems to be the general view within civil society as well. A study by the PO-PSM found that the public perceived corruption to be on the decrease but barely so. (Figure 7.10 on the next page shows perceptions about changes in corruption.) In fact, the majority of the respondents felt that not much had changed and contradicted the surveys undertaken by Transparency international. The Transparency International Corruption Perception Index trend shows corruption in Tanzania on a consistent decrease.

Figure 7.10 shows that $34 \%$ believe that the corruption stance of the public service has improved while $26 \%$ believe that it has worsened. Forty percent however, believe that no change has occurred. This implies that in spite of the numerous programs that government has put in place to corruption, a lot still needs to be done. Yet, the

\footnotetext{
${ }^{544}$ Interview with Mr. Magambo, Nashon, B. S., Commissioner Budget, Ministry of Finance, held July 31, 2006.
} 
Tanzanian government can find comfort in knowing that one of the most reputable corruption assessment organizations has reported better results.

\section{Figure 7.10 PO-PSM Assessments on Changes in Corruption}

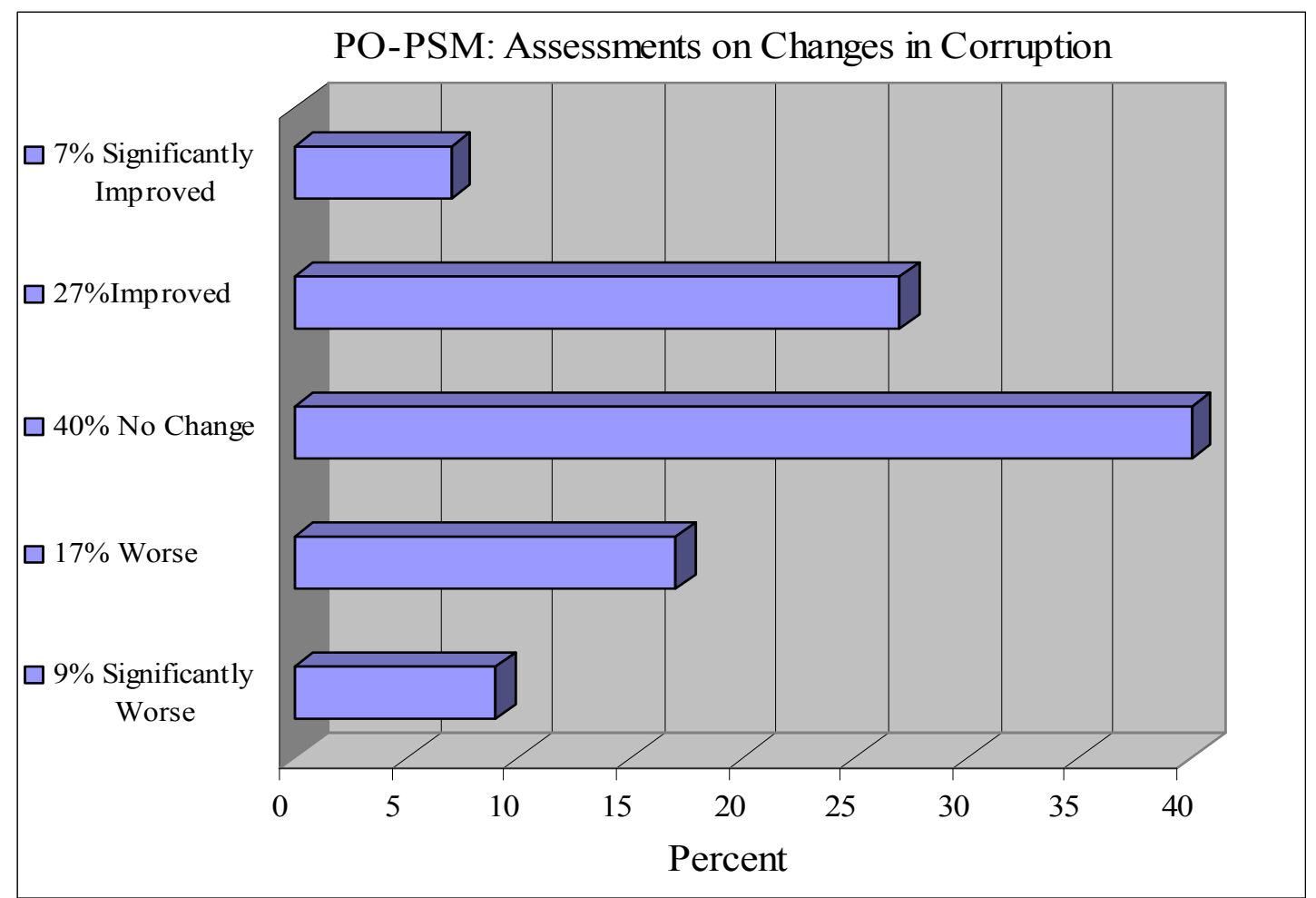

Source: United Republic of Tanzania. President's Office - Public Service Management. 2008. PSRP Phase 1 End of Programme Report: A Summary of Results 2003-2007, Dar es Salaam, p. 12.

Table 7.9 shows the corruption perception index trend generated by Transparency International surveys. Table 7.9 depicts an evidently consistent decrease in corruption. The CPI scores show a clear improvement in the degree to which corruption is perceived to exist among public officials and politicians in Tanzanians from a very low 1.9 when the country was the fourth most corrupt country out of 58 in 1998 , to a high 3.0 in 2008 when the country was $78^{\text {th }}$ out of 180 countries surveyed. The above scores show that the gains left behind by President Mkapa at the end of 2005 have so far been 
improved upon by the new president. The trend shows a positive and consistent change for the better that has been applauded and supported by international donors. ${ }^{545}$ It can therefore be asserted that although corruption still pertains in the public service, some progress has been made. It should be noted that the above achievements have been partly possible because of the efforts of the Prevention of Corruption Bureau.

Table 7.9 Tanzania's Corruption Perception Index Ranking, 1998-2008

\begin{tabular}{|c|c|c|c|}
\hline YEAR & FROM TOP & FROM BOTTOM & CPI SCORE \\
\hline 1998 & 81 out of 85 & $4^{\text {th }}$ & 1.9 \\
\hline 1999 & 93 out of 99 & $6^{\text {th }}$ & 1.9 \\
\hline 2000 & 76 out of 90 & $15^{\text {th }}$ & 2.5 \\
\hline 2001 & 82 out of 91 & $9^{\text {th }}$ & 2.2 \\
\hline 2002 & 71 out of 102 & $31^{\text {st }}$ & 2.7 \\
\hline 2003 & 92 out of 133 & $41^{\text {st }}$ & 2.5 \\
\hline 2004 & 90 out of 145 & $55^{\text {th }}$ & 2.8 \\
\hline 2005 & 86 out of 158 & $72^{\text {nd }}$ & 2.9 \\
\hline 2006 & 93 out of 163 & $70^{\text {th }}$ & 2.9 \\
\hline 2007 & 94 out of 179 & $85^{\text {th }}$ & 3.2 \\
\hline 2008 & 102 out of 180 & $78^{\text {th }}$ & 3.0 \\
\hline
\end{tabular}

Source: Transparency International. www.transparency.org. Accessed December 8, 2008.

\section{The Prevention of Corruption Bureau:}

The Prevention of Corruption Bureau (PCB) is one the major national watchdog agencies established by parliament. It has three major roles: first, it is supposed to take necessary measures for prevention of corruption in government and private sectors;

\footnotetext{
${ }^{545}$ In 2006, The World Bank gave Tanzania a US\$ 40 Million Credit to enhance Accountability, Transparency and Integrity - see The World Bank 2006. Public Sector Reform and Capacity Building. Report No: 35615 - TZ.
} 
second, it has the mandate to investigate allegations of corruption and persecute those found guilty of corruption; and third, it is supposed to advise the government and its agencies on ways and means to prevent corruption. It is headed by a director who is appointed by the president and reports not to parliament, but to the president. The PCB has offices in all regions of the country and has 43 offices at the district level. It has policing powers - it can enter and search premises as well as arrest suspects and prosecute (with the approval of the Director of Public Prosecutions - DPP) those found guilty. It also undertakes awareness and educational campaigns, and carries out research and diagnostic survey studies in MDAs to guide the formulation of strategies to fight corruption.

It was asserted that the financial and manpower of the PCB has been enhanced substantially for instance staff was increased from 185 in 1995 to 527 in 2002 and its budget was increased from 191 million Tanzanian Shillings in 1995 to 3 billion in 2002. ${ }^{546}$ Further, an anti-corruption law containing provisions that allow the PCB unfettered access to information was passed by parliament in 2006. The changes have made it possible for the agency to expand its reach especially in investigation and awareness campaigns. Nonetheless, there was a general view that the PCB suffers from some weaknesses that hinder its performance. Despite the increase in the budget, the resources are still insufficient to enable it to carry out its roles and functions. The most notable challenge is poor rates of convictions. For instance, between 2002 and 2004 7,058 cases were reported, 138 were investigated and on average only 24 convictions

\footnotetext{
${ }^{546}$ Interview No. BW 0012.
} 
were made. ${ }^{547}$ Part of the problems is lack of personnel but it is also recognized that investigations and convictions take a very long time because of the bureaucratic delays that emerge in the collection of evidence and because of the involvement of the DPPs office. $^{548}$ There is also a general belief that the PCB "lacks teeth" as it focuses more on petty corruption and not so much on grand cases of corruption. The only time a high profile case was conclusively dealt with is when the Minister of Works and his Permanent Secretary were prosecuted for corruption. However, the Minister was later released from jail but the Permanent Secretary is still serving his sentence.

\subsubsection{Challenges in Enhancing Ethics and Accountability in the Tanzanian CS}

The analysis offered in the pages above shows that some improvement has been made in building the ethical stance of the civil servants and in enhancing accountability within the Tanzanian public service. Although different surveys have shown varying degrees of progress, the study participants were quite optimistic that the achievements made are real and will be sustained. A new procurement law has permitted greater transparency and accountability in the process of procurement, the public is more involved in reporting cases of office abuse and demanding better services, public servants are getting the training and tools necessary to guide them in dealing with ethical dilemmas, the PCB has improved staffing levels and opened offices in all the regions in

\footnotetext{
${ }^{547}$ United Republic of Tanzania. President's Office-Public Service Management. 2005. State of the Public Service Report 2004. Dar es Salaam.

${ }^{548}$ Interview No. BW 0012.
} 
the country, and there is great political will to strengthen ethics and accountability in government.

Nevertheless, corruption is still considered a serious problem in the Tanzanian public service and the majority of the public do not see any change in corruption levels. Not all public officers abide by the leadership code and non-compliance has so far not been met with strict legal action. Client service charters and OPRAS are not abided by and there is no evidence that poor performance is punished. Watchdog agencies, despite some achievements still experience major weaknesses in monitoring, enforcement, and execution of their mandates. The perception that the public servants do not abide by ethical standards is still prevalent both within the public service and in the civil society.

Yet, when compared to the period prior to the reform, the current situation shows great improvement. Fighting corruption and enhancing ethics and accountability are extraordinarily complex and daunting tasks. Institutional reforms and change of behavior and mindset of public servants and the involvement of stakeholders are critical components in achieving those tasks. So far, the reforms are in consistent progress, and political goodwill and exemplary leadership have been exhibited, training and performance improvement and accountability measures are in place, the NACSAP was implemented, and watchdog bodies have been reenergized. In addition, public awareness campaigns have been implemented and the public is more vigilant in demanding ethical behavior and accountability. It can therefore be asserted that enhancing ethics and accountability is on course to becoming a reality in the Tanzanian civil service. 


\subsection{SUMMARY}

Chapter 7 has offered an analytical description and assessment of the major findings in the study of the Civil Service Reform Program (CSRP) in Tanzania. The government of Tanzania embarked on administrative reform in 1991 and officially started implementation in 1993. The CSRP focused on cost containment, reduction of the size of the civil service via restructuring, and pay reform. The CSRP lasted till 1999 and major achievements were made under that phase.

The results show that in order to reduce costs, government roles and functions were evaluated, redefined, and rationalized. A decentralization program to decongest the center was implemented, non-core functions were contracted out to the private sector, while some functions were released to executive agencies. As a result, Ministries, Departments and Agencies were reduced by $25 \%$. The size of the civil service was significantly reduced from 360,000 in 1993 to 260,000 in 2007 . The size reduction was attained through the removal of ghost workers, retrenchment of nonperformers and overdue leavers, and voluntary retirement.

The results indicate improvements were made in pay reform. The pay structure and payroll system were rationalized, and a computerized payroll and human resource system was put in place. Allowances were monetized, reduced from 36 to 7 and consolidated into basic salary. Salaries have been enhanced in real terms and a more transparent and efficient pay structure has been established. Between 2000 and 2006, real salaries were enhanced by an annual average compounded increase of $12.1 \%$.

However by the end of the 1990s, it was apparent that CSRP was limited in scope and design. A need to reorient the reform process from cost containment to performance 
enhancement was appreciated and this led to the second phase of administrative reform, the Public Service Reform Program (PSRP). The second phase, originally set to cover the period 2000-2005, lasted till 2007 and focused on the installation of performance management systems in order to professionalize the public service, and enhance capacity and accountability.

The results show that capacity building efforts have not met their targets. Training needs assessment has not been completed in all MDAs, and staff development plans have not been prepared by all MDAs. Further, a training policy is yet to be completed to streamline training and match it with MDA needs. However, various training programs have been offered including courses in leadership, customer service, Information Communication Technology (ICT), and OPRAs; and national training institutions have been strengthened. Capacity building was supposed to increase the skills and competency of the public servants so that they can provide services efficiently and effectively. In spite of the training so far given, it cannot be asserted that the public service is more competent. Until training is based on needs and performance benchmarks are put in place, capacity building will remain rhetoric.

My study found that great strides have been made in enhancing ethics and accountability in the Tanzanian public service. Ethics awareness programs are in place, a new code of ethics and conduct was availed to public servants, ethics training has been undertaken, a Leadership Code is in place, a National Anti-corruption Strategy and Action Plan was initiated, and the watchdog agencies have been revitalized. Generally, the corruption perception surveys indicate a decreasing rate of corruption in the public service. 
Nonetheless, ethics and accountability are still great challenges. The study participants acknowledged that corruption is still an enduring problem and the civil society complaints and perceptions concur. It is therefore not surprising that the next phase of the reform is focusing on enhancing performance and accountability. However, because the reform program enjoys great political will and the new president is committed to stamping corruption out of government, it is contended here that reforming the public service into an ethical and accountable system is on course.

My study has shown that the CSRP and PSRP in Tanzania have been gradual but steady endeavors. The size of the civil service was been reduced, salary has been enhanced, ethics and accountability have improved, and small gains have been attained in capacity building. Overall, the reform strategy has generated considerable success. Implementation has been guided by viable strategies which have to a large extent been abided by. A case in point is the pay strategy. In addition, the reform is being implemented in a stable and conducive political environment. Tanzania is characterized by political legitimacy and relatively high levels of commitment and motivation by the political leadership, especially since 1995 . In addition, the country has for quite some time enjoyed great donor financial support which has made it possible to implement some expensive initiatives like SASE. It is no wonder that the reform rhetoric is steadily turning into reality. 


\section{CHAPTER 8: THE CIVIL SERVICE REFORM PROGRAMS IN UGANDA AND TANZANIA: A COMPARISON}

\section{1 INTRODUCTION}

The discussion offered in chapters six and seven has shown that the civil service reform programs in Uganda and Tanzania share similarities in the objectives and content. Both countries aimed at reducing the size of the service, increasing salaries, enhancing capacity, and improving ethics and accountability. Both countries undertook size reduction measures, improved pay, undertook training and other capacity building efforts, and established agencies to foster ethics and accountability. Chapter five however showed that the programs were implemented under differing contexts such that each country embarked on the reform trajectory in a unique context. Hence, although the reform programs are similar, implementation has been varied and outcomes are equally unique as has been shown in chapters six and seven. Chapter eight offers a comparison of the implementation trajectory and explains what accounts for the similarities and differences in the paths taken and outcomes attained. It is proposed that the differences are a result of the nature of the political leadership, political institutionalization, and the role of donor funding.

\section{2 THE NATURE OF THE POLITICAL LEADERSHIP}

The outcomes of the CSRP in the two countries have depended on the nature of the political system and political leadership under which implementation has been taking place. The first phase of reform program in Uganda 1991 - 1997 was greatly shaped by President Museveni. He enjoyed substantial local and international support and 
legitimacy, and was viewed as a strong and able leader that had reestablished peace in Uganda. His local preoccupation and priorities were in sync. He was committed to transforming the administrative, economic, and political institutions of the country that had endured a horrendous period of turmoil into strong, viable, effective and efficient institutions. His actions were instrumental in declaring to all civil servants that he was committed to the CSRP and expected everyone else to follow suit. A member of the PSRRC asserted that the president's commitment to the reform played a major role in accelerating implementation progress. Describing the president's role in reduction of the CS size he asserted:

"In a surprising and swift stroke of the pen, President Museveni reduced the number of ministries from 32 to 21 in $1992 \ldots$ This action by the president was a strong message to the conservative mainstream of the civil service. If ministers could be removed from office to promote efficiency and economy, then similar retrenchment had to be carried out at all lower levels of government. ${ }^{, 549}$

Past research confirms the view that President Museveni played a significant role in the initial stages of the CSRP. Kjaer (2004) called the president "a new broom" asserting that "the president was able to act as a new broom intervening in favor of reform and accelerating implementation., ${ }^{550}$ The CSRP in Uganda therefore started with great vigor because the political leadership, the civil servants, and general public wanted to move forward from the administrative, economic and political malaise that the country endured.

\footnotetext{
${ }^{549}$ Katorobo J. 1996. “The Public Service Reform Programme.” In Mugaju, J. B. (ed.) Uganda's Decade of Reforms 1986-1996: An Analytical Review. Kampala: Fountain Publishers, p. 48.

${ }^{550}$ Kjaer, A. M. 2004. "Old Brooms can Sweep Too!: An Overview of Rulers and Public Sector Reforms in Uganda, Tanzania and Kenya." Journal of Modern African Studies, Vol. 42, No. 3, p. 397.
} 
President Mwinyi (1985-1995) on the other hand, is not credited for engendering progress in the CSRP implementation although the program began during his reign. It has been asserted that he focused his energies on only dismantling the remnants of socialism and implementing the WB and IMF programs for economic liberalization. Contrary to the goals of civil service size reduction he increased an inherited fifteen ministers to thirtyfive and only let go of six following domestic and external pressure. ${ }^{551} \mathrm{Kiragu}$ and Mukandala (2005) assert that under his reign no significant pay raise was effected, but rather, "The government policy was to allow employees to take on other activities to supplement their incomes, and hopefully help in the economic recovery." of the minimal political support and leadership that unlike Uganda's, the CSRP in Tanzania started tentatively. His successor, President Benjamin Mkapa (1995-2005) however, was a more dynamic, committed, and versatile leader. "The pace of restructuring, retrenchment, and pay reform were revitalized by President Mkapa"553 one of the study participants said, and there was general agreement that it is under President Mkapa that the major changes were realized. Indeed President Mkapa has been applauded for re-energizing the CSRP and introducing new blood into government, and fresh ideas

\footnotetext{
${ }^{551}$ Kjaer, A. M. 2004. "Old Brooms can Sweep Too!: An Overview of Rulers and Public Sector Reforms in Uganda, Tanzania and Kenya.” Journal of Modern African Studies, Vol. 42, No. 3, p. 400.

${ }^{552}$ Kiragu, K. and Rwekaza Mukandala. 2005. Politics and Tactics in Public Sector Reforms: The Dynamic of Public Service Pay in Africa. Dar es Salaam, Dar es Salaam University Press Ltd, p. 219.

${ }^{553}$ Interview with the former Permanent Secretary President's Office - Public Service Management, Mr. Joseph Rugumyamheto, held June 29, 2006.
} 
into the reform process. ${ }^{554}$ At the time of data collection, there was general optimism that the new President, Jakaya Kikwete (2005- ), will keep the momentum going.

Although Uganda started the reform program with great vigor and support, Tanzania has caught up with it and in some areas like ethics and accountability has overtaken it. After the initial success was attained, the program slowly but surely stagnated. Indeed some of the gains previously achieved have been reversed. Neopatrimonial and clientelist politics have taken over. The president is now more concerned with securing his power base than in reforms. Executive agencies proliferate, and are arguably headed by the president's cronies, pointing to the fact that distribution of patronage abounds. Corruption rates are still high and support for reform is only lukewarm. It is therefore my contention that there is an association between the waxing and waning of political legitimacy and the efficiency of administrative reforms. This turn of events is better understood by looking at political institutionalization in Uganda.

\subsection{VIABLE POLITICAL INSTITUTIONS}

Tanzania is currently performing better than Uganda because the reforms are being driven from the top political-administrative level and are taking place in a political context where the political leadership enjoys legitimacy. The country has developed a culture of democratic succession of power and has an across-ethnic lines united and dominant political party. The democratic culture has engendered implementation of bold steps without worrying about political survival. In Uganda, uncertain political leadership

\footnotetext{
${ }^{554}$ See Glickman, H. 1997. "Tanzania: From Disillusionment to Guarded Optimism.” Current History, May, pp. 217-221.
} 
succession is hampering reform efforts. President Museveni has been in power since 1986. He was democratically elected in 1996 after the passing of the new Constitution in 1995 under a Movement system of government, and reelected for a second term in 2001. However, in 2002, he orchestrated the reversal of term limits, reintroduced multiparty politics, and paved the way for his reelection in 2006 under what was widely believed to be unfree and unfair elections. There is a general belief that he will not leave power democratically. The country has since the early 1990s been experiencing political instability in the northern part of the country. In the late 1990s more civil strife emerged in the eastern part of the country. The two insurgencies have exacerbated the president's anxiety to hold on to power. Political instability has meant that resources allocated for the reform program have been diverted to quell insurgence and to support military operations.

Tanzania on the other hand is one of the most stable nations in Africa largely to the credit of the country's first president, Julius Nyerere who encouraged national brotherhood and a local common national language. The country has not experienced a civil war since independence, and the since political pluralism was introduced in 1995, elections results have not been contested or said to have been rigged. The country has therefore since 1995 steadily pursued civil service reform in a systematic manner. New public management prescriptions like performance management systems and client service charters have been instituted and are being adhered to by MDAs. This is not the case in Uganda where there is no demonstrable understanding and commitment on the part of the top leadership to allocate of the necessary resources to implement performance measurement procedures and to keep the reform process in on course. 


\subsection{THE ROLE OF INTERNATIONAL DONORS}

International donors have played a tremendous role in providing the funding and technical support for reform in the two countries. Initially, Uganda benefitted the most from donor support. Between 1987 and 1996, President Museveni was lauded for visionary and transformative leadership, and was hailed as "new breed" of African leaders. He was committed to bring about fundamental change in the administrative, economic, political, and legal sectors of the country. The economy was stabilized, a new constitution promulgated, and the civil service reform achieved immediate success in size reduction and pay reform. In the late 1990's however, the pace slowed down because the president became preoccupied with maintaining himself in power. As a result, donor support started to wane as it became increasingly clear that he will do everything possible to retain the presidency. In addition, there is a strong sense the he is not committed to routing corruption out of the government. The rate of corruption figures presented in chapter six and chapter seven show that Tanzania is doing better at reining in corruption. The reduction in donor funding has meant that funding for the reform has become scarce and unpredictable.

Donors have played a significant role in the CSRP in Tanzania as well. The economic, political and administrative systems in Tanzania underwent tremendous change under the nudging guidance of the IMF and WB. The socialistic economy was liberalized, the single party system abandoned for a vibrant multiparty political system, and the civil service reform was initiated and is progressing steadily. Currently, the country enjoys higher donor favor because it is abiding by the IMF/WB prescriptions better than Uganda. 
It can therefore be argued that, the principal explanations for differences in the CSRP outcomes is neo-patrimonial politics, lack of democratic political institutions, and the gradual withdrawal of donor funding. In spite of the above differences, the civil service reform programs in the two countries share some similarities. In both countries, the reforms have been a top-down exercise with very limited civil society participation. Indeed, there is no evidence of popular civil society demand for better implementation. The masses are not well informed but also because the governments have been reluctant to educate them and include them in reform processes. Tanzania however is making effort to publicize the reforms and to attract public input. ${ }^{55}$ In addition, the Tanzanian public has been encouraged to hold public servants accountable through mechanisms like the civil service charters and OPRAs. Such mechanisms are absent in Uganda.

In both countries, new organizations and structures were created to specifically advance reform. In Uganda, the administrative reform secretariat in the Ministry of Public Service is in charge, while in Tanzania the Public Service Management in the President's office is in charge. This is in line with NPM prescriptions and has been possible because of donor funding. In both countries then, donor funding has been extremely important and the success of some of the reforms has largely depended on the generosity of foreign donors. For instance, SASE in Tanzania would not have been possible without donor funding, and the retrenchment in Uganda would not have been as smooth without donor funding.

\footnotetext{
${ }^{555}$ A Public Service Fair was held between June 19-23, 2006 to educate the public about the CSRP. Various documents, manuals and books were availed to the public - personal observation.
} 
Empirical evidence presented in this study shows that the two countries attained great success in reducing the number of public servants. Although the size is increasing again, the increase is justified because recruitment is being undertaken in service sectors like education and health, sectors that are critical to development and poverty eradication. Moreover, recruitment follows strict guidelines and is monitored through the personnel information system by both Ministry of Public Service and Ministry of Finance in Uganda, and the President's Office - Public Service Management and Ministry of Finance in Tanzania. Below is a comparative depiction of the reforms.

Table 8.1 Comparison of Civil Service Reforms in Uganda and Tanzania

\begin{tabular}{|c|c|c|c|}
\hline CSRP Focus & Elements & Uganda & Tanzania \\
\hline $\begin{array}{c}\text { Reduction of the Size } \\
\text { of the CS }\end{array}$ & $\begin{array}{l}\text { - Rationalization and } \\
\text { restructuring of Ministries } \\
\text { - Retrenchment } \\
\text { - Voluntary Retirement } \\
\text { - Removal of Ghosts }\end{array}$ & 3 & 3 \\
\hline Pay reform & $\begin{array}{l}\text { - Rationalization of salary } \\
\text { structures } \\
\text { - Computerization of payroll } \\
\text { - Systematic salary } \\
\text { enhancement }\end{array}$ & 2 & 3 \\
\hline Capacity Building & $\begin{array}{l}\text {-Training needs assessment } \\
\text {-Training policy } \\
\text {-Hire of qualified staff } \\
\text { - Staff training }\end{array}$ & 2 & 1 \\
\hline $\begin{array}{c}\text { Ethics and } \\
\text { Accountability }\end{array}$ & $\begin{array}{l}\text {-Anti corruption strategies } \\
\text { - Democratization } \\
\text {-Strengthening governance } \\
\text { and watchdog bodies } \\
\end{array}$ & 1 & 3 \\
\hline Overall performance & $\begin{array}{l}\text {-Performance improvement } \\
\text {-Performance measurement } \\
\text {-Consistency of the reform }\end{array}$ & 2 & 3 \\
\hline
\end{tabular}

Key: The table portrays the intensity levels and consistency in reform implementation. 0 represents no action, 1 minimal action, 2 some considerable action, and 3 the highest degree of action. 


\subsection{SUMMARY}

In chapter eight, I have shown that the nature of the political leadership and political legitimacy, presence of democratic institutions, and international donors have contributed to the differences between the reform trajectory in Uganda and Tanzania. It has been shown that in both countries, administrative reform peaked as the country was at a peak in political reformation. Consequently, I can conclude that Uganda will continue to falter in its administrative reforms until President Museveni changes his leadership stance or losses power. In the case of Tanzania, the ruling party, the CCM, needs eventually to face more credible opponents. If that does not happen, the CCM will be correctly viewed as a single party rule and administrative reform will eventually falter there too.

Table 8.1 shows that Tanzania has generally performed better than Uganda. The reduction of the size has been a success in both countries; Uganda has done better in capacity building; but in pay reform and ethics and accountability, Tanzania has done much better. Based on the findings, it can be asserted that Tanzania has a better perspective on reform with clear and distinct strategies, while Uganda has since the late 1990s regressed to incrementalism, muddling through particular crises and pressures as they arise. 


\section{CHAPTER 9: CONCLUSIONS AND RECOMMENDATIONS}

\subsection{INTRODUCTION}

Chapter nine offers a summary of the study, discusses the conclusion, provides recommendations, offers the limitations of the study, and identifies the opportunities for future research. My study was an ambitious one that aimed at remedying some of the weaknesses in the current literature on administrative reform in developing countries. Ambitious because it is an empirical comparative study, that covers two countries that although on the surface may look quite similar, are rather different mainly because of the historical, economic, and political developments, and current political contexts. A comparative study was favored because there is a paucity of genuine and rigorous comparative, multi-country studies that focus on developing nations. Much of the existing literature focus on one country, or one program, or one sector. My study has therefore generated new data to strengthen the field of comparative administration.

The two countries were focused on because more than ten years since implementation was effected in 1991 and 1993 in Uganda and Tanzania respectively, no comprehensive and empirical comparative assessment of the results had been undertaken. Moreover, unlike previous studies that only focus on the post-independence period, my study offers the pre-colonial historical background, and the development of the administrative, economic, and political contexts of both countries. It has illustrated how the historical context has had a great impact on the countries' civil services. The current study is the first to illustrate that in Uganda and Tanzania, while administrative reform morphed from structural adjustment conditionality programs, the end result has not been mere civil service reform and economic stabilization. It has shown that the program goals 
have been reoriented towards bigger national goals of good governance and poverty eradication.

\subsection{CONCLUSIONS AND RECOMMENDATIONS}

The civil service reforms in Uganda have been successful in the reduction of the size of the civil service but have fallen short in pay reform, capacity building, and ethics and accountability. In Tanzania, success was attained in civil service size reduction, in pay reform, and in enhancing ethics and accountability. However, minimal progress was achieved in capacity building. The reasons that account for this performance have been adequately covered in the chapters six, seven, and eight.

If the reforms of the civil services in Uganda and Tanzania are going to be successful in attaining the set goals and objectives, they must be guided by comprehensive strategies that categorically specify what steps will be taken at different points along the process, and the government has to abide them. Tanzania has so far been steady in abiding with the reform strategies. For instance, the government has been consistently increasing civil servants' salary within the medium term pay policy framework. As one participant observed; "We have a medium term pay policy, a medium term pay strategy, and medium term pay targets. Government is pursuing the three as consistently as it can. That is the most important point and I think that is the difference between Tanzania and Uganda on the issue of pay. The politicians do not panic here, if 
the doctors strike you don't say we give them this, there is a methodology for dealing with pay."

A comprehensive and strategic approach of the reform programs does not imply that all the problems that dogged the civil service systems in the two countries must be solved within the same timeframe, but rather that the inter linkages between the different problem areas must be analyzed and put into consideration in the reform process. Piecemeal and fragmented reforms programs are rarely effective, and if they are, the outcomes are not easily sustained. For instance, capacity building implemented in isolation from pay reform, or size reduction not supplemented with pay reform and capacity building will rarely attain the desired goals. Consequently, a well thought out and viable reform strategy is critical. Such a strategy needs to be not only comprehensive in scope but well integrated in focus. A successful reform strategy therefore is one that creates and sustains conditions in which steady improvements can flourish.

Successful reform requires strong and sustained political will. The CSRP in the two countries have a political nature which makes them more difficult. The reforms entail some radical alterations in the way government business is handled. Elements like ethics and accountability have a bearing on the political stance of those in political power as well as those in bureaucratic leadership positions. Consequently, the reforms call for strong and continued political support, and willingness to exercise the political power to enforce unpopular changes. The Ugandan and Tanzanian governments need to remain fully committed to, and supportive of, the reform process. At present, Tanzania enjoys

\footnotetext{
${ }^{556}$ Interview with Professor Gelase Mutahaba Chief Technical Advisor, President's Office - Public Service Management, held, June 29, 2006.
} 
more commitment and support from the top political leadership, and seems to have viable strategies that will engender sustainability.

Political commitment, and stable, democratic political processes in the country are important ingredients for successful policy implementation. Tanzania has both. The country's current political leadership enjoys political legitimacy and democratic elections have been consistently held. Uganda on the other hand seems to have lost its earlier zeal. Unlike Tanzania, the Ugandan political leadership does not enjoy full legitimacy. Preoccupied with quelling insurgencies in the northern and eastern parts of the country, it is paying little attention to reform program. The CSRP is thus being starved of necessary financial and political support. It can therefore be asserted that until political stability and legitimacy are attained in Uganda, prospects for effective reform will remain grim.

The role of the civil society has not been pronounced in the reform processes in both countries. Public relations drives focusing on clearly thought out themes like ethics, integrity, accountability, and better service delivery should be implemented. Such drives would not only help create an enabling environment for the reform programs, but would also encourage civil society participation in holding civil servants accountable.

Many of the problems that the reform programs in the two countries seek to eliminate require persistent and continuous effort to eliminate. Payrolls have to be monitored periodically to ensure that ghosts do not emerge, salary increments have to continue, capacity building efforts must be period and continuous, and efforts to enhance ethics and accountability have to remain relentless. The effectiveness of reforms will therefore depend of sustenance. Uganda for quite a long time enjoyed favorable press partly because of the traumatic history it emerged from - predicting a good reform 
trajectory. Although Tanzania embarked on the reforms slowly, it is contended here that it actually has a firmer and more stable base, and a more sustainable reform trajectory.

In conclusion, it is important to stress that in spite of the shortcomings that have pervaded the implementation of the reform programs in the two countries; the reform process has not been a meaningless charade. Very visible, tangible, and beneficial outcomes have been attained. The reforms have generated definite payoffs in reducing the size of the civil services, increasing pay levels, enhancing capacity, and reorienting the ethical stance of public servants, even if longer term outputs remain relatively obscure.

\subsection{LIMITATIONS OF THE STUDY}

It has been indicated that the reform programs in Uganda and Tanzania have relied heavily on foreign assistance in both formulation and implementation. It would therefore have been beneficial to interview subjects from donor agencies. Their views would have provided a different perspective about the reforms.

As is common with most case study qualitative studies, generalization of findings provided by the study beyond the scope of the two countries should be avoided. Moreover in this particular study, reform is context specific and the findings provided here illuminate the context in Uganda and Tanzania only. Nonetheless, extrapolations from lessons learned and recommendations offered are possible, and can be useful to those interested in understanding why reforms succeed or fail, or how they can be better implemented. 


\subsection{RECOMMENDATIONS FOR FUTURE RESEARCH}

First, although this is a unique study, administrative reform is very wide and complex, and judging performance entails getting evidence from different stakeholders. However important the perceptions of those involved in implementation are, they do not adequately address whether service delivery has improved. Future research should therefore focus on the micro level and asses the impact of the reform program on service delivery from the point of view of the recipients - the masses. In the two countries, reforms have been reoriented; they are now being undertaken with the aim of realizing a larger vision - poverty eradication. Poverty eradication serves a useful function of rallying donor support and domestic support. Future research should assess if the poverty eradication vision is being realized. The gap between rhetoric and reality at micro level might shed even more light on how to improve the programs.

Second, more comparative studies are needed in other aspects of the reform especially results oriented management and performance improvement, public-private partnerships, decentralization, and management information systems. These areas are critical to performance and service delivery; studying them would generate valuable insights about performance improvement.

Third, controversy still abounds as to what the optimal size of the civil service should be. Findings in this study suggest there is need to study how other countries make judgments about the right size of government. For instance, although the size is increasing again in the two countries, the increase is justified because recruitment is being undertaken in service sectors like education and health, sectors that are critical to development and poverty eradication. Moreover, recruitment in those areas follows strict 
guidelines and is monitored through the personnel information system by both Ministry of Public Service and Ministry of Finance in Uganda, and the President's Office - Public Service Management and Ministry of Finance in Tanzania. Future research should compare civil service numbers of "good reformers" like Ghana, countries in East Asia, and developed countries that have a longer reform history like the UK and USA for benchmarks.

Lastly, my findings show that there is an association between the pace of democratic political reform that the country is experiencing and the pace of administrative reform. In Uganda, between the years 1986 to 1996, President Museveni embraced popular democratic political reform and during the same time frame, the CSRP performed best. As the pace of political reform reduced and his political legitimacy came under question, the pace of civil service reform also reduced. In Tanzania, before the country embraced multi party politics (1985-1995), administrative reform faltered. Since the introduction of multi party politics and the subsequent peaceful change in political leadership, civil service reform has performed better. Future research should therefore empirically test the following hypothesis: there is a relationship between political legitimacy and the efficiency of administrative reform. 


\section{REFERENCES}

Books

Amani, H. K. R. et al 2006. "Understanding Economic and Political Reforms in Tanzania." In Mensah, J. (ed) Understanding Economic Reforms in Africa. New York: Palgrave Macmillan.

Babbie, E. 2005. The Basics of Social Research. Belmont, CA: Thomson Wadsworth. Barber, William. 1961. The Economy of British Central Africa. London: Oxford University Press.

Bagachwa, M. S. D. and Limbu, F. 2006. In Amani, H. K. R. et al 2006. "Understanding Economic and Political Reforms in Tanzania." In Mensah, J. (ed) Understanding Economic Reforms in Africa. New York: Palgrave Macmillan.

Berg, B. L. 2004. Qualitative Research Methods for the Social Sciences. Boston: Pearson Education Inc.

Blau P. M. and Marshall W. Meyer 1987 ( ${ }^{\text {rd }}$ ed.) Bureaucracy in Modern Society. New York: McGraw-Hill Publishing Company.

Boahen, A. A. 1987. African Perspectives on Colonialism. Baltimore: The Johns Hopkins University Press.

Boesen, J. 1976. "Tanzania: From Ujamaa to Villagization." Institute for Development Research, Copenhagen, Paper A76.7, p. 13. In Coulson, A. 1982. Tanzana: A Political Economy. London: Clarendon Press.

Boyatzis, R. E. 1998. Transforming Qualitative Information. Thousand Oaks, CA: Sage. Burke, F. G. 1964. Local Government and Politics in Uganda. Syracuse: Syracuse University Press.

Butcher, T. 2003. "Modernizing Civil Services: An Era of Reform.” In Butcher, T. and Andrew Massey. Modernizing Civil Services. Cheltenham, UK: Edward Elgar.

Caiden, E. G. 1991. Administrative Reform Comes of Age. New York: Walter de Gruyter.

Cameroon, D. 1939. My Tanganyika Service and Some Nigeria. London: George Allen and Unwin.

Cheema, G. S. 2005. Building Democratic Institutions: Governance Reforms in Developing Countries. Bloomfield, CT: Kumarian Press. 
Chege, M. 1994. "Swapping Development Strategies: Kenya and Tanzania After their Founding Presidents." In Political Development and the New Realism in Sub-Saharan Africa. Apter, D. E. and Carl, G. Rosberg (eds) Charlottesville: University Press of Virginia.

Clarke, J. and David Wood. 2001. "New Public Management and Development: The case of Public Service Reform in Tanzania and Uganda." In McCourt, W. and Martin Minogue (ed) The Internationalization of Public Management: Reinventing the Third World State. Cheltenham, UK: Edward Elgar.

Cliffe, L. 1969. "From Independence to Self-Reliance." In Kimambo, I. N. and A. J. Temu (eds) A History of Tanzania. Nairobi: East African Publishing House.

Cook, T. D. and Donald T. Campbell. 1979. Quasi-experimentation: Design and Analysis Issues for Field Settings. Chicago, Ill: Rand McNally College Publishing Company.

Crozier, M. 1964. The Bureaucratic Phenomena. Chicago: University of Chicago Press.

Coulson, A. 1982. Tanzana: A Political Economy. London: Clarendon Press.

Das, S. K. 1998. Civil Service Reform and Structural Adjustment. Oxford: Oxford University Press.

Denhardt, J. V. and Denhardt, R. B. 2003. The New Public Service: Serving, not Steering. New York: M. E. Sharpe.

Denzin, N. K. 1978. The Research Act: A Theoretical Introduction to Sociological Methods. New York: McGraw-Hill.

Farazmand, A. (ed) 2002. Administrative Reform in Developing Nations. Westport, CONN: Praeger.

Frederickson, H. G. and Kevin B. Smith. 2003. The Public Administration Theory Primer. Boulder, CO: Westview Press.

Friedrich, C. J. 1963. Man and his Government. New York: McGraw-Hill Book Company.

Goodnow, F. J. 1900. Politics and Administration: A Study in Government. In Shafritz, J. M., Albert C. Hyde, and Sandra J. Parkes. 2004. Classics of Public Administration (5 ${ }^{\text {th }}$ ed.) London: Thomson-Wadsworth.

Haggard, S. 1997. "Reform of the State in Latin America." In Burki, S. J. and Perry Guillermo eds. Development in Latin America and the Caribbean. Washington, D. C.: World Bank. 
Heady, F. 2001. Public Administration: A Comparative Perspective. $6^{\text {th }}$ ed. New York: Marcel Dekker, Inc.

Hirst, P. 2000. "Democracy and Governance" in Pierre, J. (Ed.) Debating Governance: Authority, Steering, and Democracy. Oxford: Oxford University Press.

Hughes, O. E. 1994. Public Management and Administration: An Introduction. New York: St. Martin's Press.

Hyden, G. 1983. No shortcuts to Progress: African Development Management Perspective. Berkeley: University of California Press.

Iliffe, J. 1979. A Modern History of Tanganyika. Cambridge: Cambridge University Press.

Jacoby, H. 1973. The Bureaucratization of the World. Berkeley, CA: University of California Press.

Jennings, I. 1971. "The achievement of British Bureaucracy" In Dalby, M. T. and Michael S. Werthman. Bureaucracy in Historical Perspective. London: Scott, Foresman and Company.

Karugire, S. R. 1980. A Political History of Uganda. Nairobi: Heinemann Educational Books.

Karugire, S. R. 1996. Roots of Instability in Uganda. Kampala: Fountain Publishers.

Kasfir, N. 1976. The Shrinking Political Arena: Participation and Ethnicity in African Politics, with a Case Study of Uganda. Berkeley: University of California Press.

Kasozi, A. B. K. 1994. The Social Origins of Violence in Uganda, 1964-1985. Montreal: McGill-Queen's University Press.

Kautsky, J. H. 1972. The Political Consequences of Modernization. New York: John Wiley and Sons, Inc.

Kenneth Ingham. 1962. A History of East Africa. London: Longmans.

Kiragu, K. 1998. "Civil Servie Pay Reform Issues and Options.” In Rugumamu, S. (es.) Civil Service Reform in Tanzania: Proceedings of the National Symposium. Dar es Salaam: University Consultancy Bureau.

Kiragu, K. 1999. "Tanzania” In Adamolekun, L. Public Administration in Africa: Main Issues and Selected Country Studies. Boulder, CO: Westview Press. 
Kiragu, K. and Rwekaza Mukundala. 2005. Politics and Tactics in Public Sector Reforms: The Dynamics of Public Service Pay in Africa. Dar es Salaam:Dar es Salaam University Press Ltd.

Langseth, P. 1995. "Civil Service Reform in Uganda: Lessons Learned." In Langseth, P, Sandile Nogxina, Daan Prinsloo, and Roger Sullivan (eds) Civil Service Reform in Anglophone Africa. Washington D.C.: International Monetary Fund.

Langseth, P. and Justus Mugaju. 1996. Post-Conflict Uganda: Towards an Effective Civil Service. Kampala: Fountain Publishers.

Light, C.P. 1999. The True Size of Government. Washington D.C.: The Brookings Institution Press.

Lincoln, Y. S. and Egon G. Guba. 1985. Naturalistic Inquiry. Beverly Hills, CA: Sage Publications.

Lord Hailey, W. 1950. Native Administration in the British African Territories. London: His Majesty's Stationery Office.

Low, D. A. 1991 “A Dislocated Polity: Uganda 1960-86" in Low, D. A. Eclipse of Empire, Cambridge: Cambridge University Press.

Mair L. 1977. Primitive Government: A Study of Traditional Political Systems in Eastern Africa. Bloomington: Indiana University Press.

Maliyamkono, T. L. and Bagachwa, M. S. D. 1990. The Second Economy in Tanzania. London: James Currey.

Mamdani, M. 1976. Politics and Class Formation in Uganda. New York: Monthly Review Press.

Mamdani, M. 1996. Citizen and Subject: Contemporary Africa and the Legacy of Late Colonialism. Princeton: Princeton University Press.

Mazrui, A. A. 1975. Soldiers and Kinsmen in Uganda: The Making of a Military Ethnocracy. London: Sage Publications.

Merton, R. 1949. "Bureaucratic Structure and Personality." In Social Theory and Social Structure. New York: Free Press Inc.

Miles, M. B. and Michael, A. Huberman. 1994. Qualitative Data Analysis. Thousand Oaks, CA: Sage Publications. 
Minogue, M. 2001. “The Internationalization of New Public Management.” In McCourt, W. and Martin Minogue. The Internationalization of New Public Management: Reinventing the Third world State. Cheltenham, UK: Edward Elgar.

Morstein, M. F. 1957. The Administrative State: An Introduction to Bureaucracy. Chicago: University of Chicago Press.

Mutahaba, G. and Baguma, R. and Halfani, M.1993. Vitalizing African Public Administration for Recovery and Development. West Hartford, CONN: Kumarian Press, Inc.

Mwapachu, J. V. 2005. Confronting New Realities: Reflections on Tanzania's Radical Transformation. Dar es Salaam: E\&D Limited.

Neman, W. L. 2000. Social Research Methods: Qualitative and Quantitative Approaches. $4^{\text {th }}$ ed. Boston, MA: Allyn and Bacon.

Nolan, B. 2001. International Public Sector Reform: An International Perspective. New York: Palgrave.

Nsibambi A. (Ed.) 1998. Decentralization and Civil Society in Uganda: The Quest for Good Governance. Kampala: Fountain Publishers.

Ntukamazina, D. A. 1998. "Civil Service Performance in Tanzania: A Strategic Perspective." In Severine M. Rugumamu (ed) Civil Service Reform in Tanzania: Proceedings of the National Symposium. Dar es Salaam: University Consultancy Bureau.

Nyerere, K. J. 1964. "Ujamaa: The Basis of African Socialism.” In Friedland, W. H. and Carl G. Rosberg, Jr. (eds). African Socialism. Stanford, CA: Stanford University Press.

Nyerere, K. J. 1968. Uhuru na Ujamaa: Freedom and Socialism. Oxford University Press. In McDonald, D. A. and Eunice N. Sahle (eds). The Legacies of Julius Nyerere: Influences on Development Discourse and Practice in Africa. Trenton, NJ: Africa World Press

ODA. 1993. Taking Account of Good Government. London: Overseas Development Administration.

Olowu, D. and Wunsch, J. S. 2004. Local Governance in Africa: The Challenge of Democratic Decentralization. Boulder, CO: Lynne Rienner Publishers.

Osborne, D and Ted Gaebler 1993. Reinventing Government. Reading, Mass: AddisonWesley Publishing Company.

Patton, M. Q. 2002. Qualitative Research and Evaluation Methods. $3^{\text {rd }}$ ed. Thousand Oaks, CA: Sage Publications, Inc. 
Pierre, J. 2000. Debating Governance: Authority, Steering, and Democracy. Oxford: Oxford University Press.

Pierre, J. and Guy B. Peters. 2000. Governance, Politics, and the State. New York: St. Martin's Press.

Polidano, C. 2001. "Administrative Reform in Core Civil Services: Application and Applicability of the New Public Management." In McCourt W. and Martin Minogue. The Internationalization of Public Management: Reinventing the Third World State. Cheltnham, UK: Edward Elgar.

Pollit C. and Geert Bouckaert. 2000. Public Management Reform: A Comparative Analysis. Oxford: Oxford Univesity Press.

Ragin, C. 1994. Constructing Social Research. Thousand Oaks, CA: Pine Forge Press.

Raikes, P. and Peter Gibbon. 1996. "Tanzania." In Engberg-Pedersen, et al. Limits of Adjustment in Africa. Oxford: James Currey.

Rosenbloom, D. H. and Robert, S. Kravchuk. 2004. Public Administration: Understanding Management, Politics, and Law in the Public Sector. $6^{\text {th }}$ ed. New York: McGraw-Hill.

Rweyemamu, A. and Hyden, G. 1975. A Decade of Public Administration in Africa. Nairobi: East African Literature Bureau.

Schwandt, T. A. 1994. "Constructivist, Interpretivist Approaches to Human Inquiry" In Denzin, N. K. and Yvonna S. Lincoln (eds) Handbook of Qualitative Research. Thousand Oaks, CA: Sage Publications.

Spear, T. 2005. "Indirect Rule, the Politics of Neo-Traditionalism and the Limits of Invention in Tanzania." In Maddox, G. H. and James L. Giblin. In Serach of a Nation: Histories of Authority and Dissidence in Tanzania. Oxford: James Currey.

Steven, M. 1994. "Public Expenditure and Civil Service Reform in Tanzania." In Rehabilitating Government: Pay and Employment Reforms in Africa. Lindauer, D. L. and Barbara Nunberg (eds.) Washington, D.C: World Bank.

Strauss, A. and Juliet Corbin. 1998. Basics of Qualitative Research: Techniques and Procedures for Developing Grounded Theory. Thousand Oaks, CA: Sage Publications.

Therkildsen, O. 1998. "Challenges of Local Government Reform." In Severine M. Rugumamu (ed) Civil Service Reform in Tanzania: Proceedings of the National Symposium. Dar es Salaam: University Consultancy Bureau. 
Trochim, W. M. K. 2005. Research Methods: The Concise Knowledge Base. Cincinnati, $\mathrm{OH}$ : Atomic Dog Publishing.

Tukahebwa, G. 1998. "Political and Administrative Relations in Decentralization." In Nsibambi A. (Ed.) Decentralization and Civil Society in Uganda: The Quest for Good Governance. Kampala: Fountain Publishers.

Tumusiime-Mutebile, E. 1995. "Management of the Economic Reform Programme." In Langseth, P., J. Katorobo, E. Brett, and J. Munene. Uganda: Landmarks in Rebuilding a Nation. Kampala, Fountain Publishers

Van de Walle, N. 2001. African Economies and the Politics of Permanent Crisis, 19791999. Cambridge, Cambridge University Press.

Waldo, D. 1948. The Administrative State: A Study of the Political Theory of American Public Administration. New York: Holmes and Meier.

Wangolo, A. M. 1995. "Uganda Civil Service Reform Programme: Implementation of the Reform Measures and Lessons Learned." In Langseth, P, Sandile Nogxina, Daan Prinsloo, and Roger Sullivan (eds) Civil Service Reform in Anglophone Africa. Washington D.C.: International Monetary Fund.

Weber, M. "Bureaucracy” In Shafritz, J. M., Albert C. Hyde, and Sandra J. Parkes. 2004. Classics of Public Administration ( $5^{\text {th }}$ ed.) London: Thomson Wadsworth.

Weber, M. "Bureaucracy" Reprinted in Shafritz et al, 2004. Classics of Public Administration. Belmont, CA: Thomson Wadsworth.

Weber, M. “The Ideal Bureaucracy” In Dalby, T. M. and Michael, S. Werthman. 1971. Bureaucracy in Historical Perspective. London: Scott, Foresman, and Company.

Weber, M. 1947. The Theory of Social and Economic Organization. Translated by Henderson, A. M. and Talcott Parsons. New York: Oxford University Press.

Were, G. S. and Derek A. Wilson. 1984. East Africa through a Thousand Years: A History of the Years AD 1000 to the Present Day. New York: Africana Publishing Company.

Woodrow, W. 1887. "The Study of Public Administration." In Political Science Quarterly, Vol. 2 Reproduced in Shafritz, J. M. and Hyde, A. C. and Sandra J. Parkes. 2004. Classics of Public Administration. $5^{\text {th }}$ ed. Belmont, CA: Thomson Wadsworth.

World Bank. 1989. Sub-Saharan Africa: From Crisis to Sustainable Growth. Washington, D.C: The World Bank. 
World Bank. 1993. Governance. Washington DC: The World Bank.

Wrigley, C. 1996. Kingship and the State: The Buganda Dynasty. New York: Cambridge University Press.

Wunsch, J. S. and Ottemoeller, D. 2004. "Uganda: Multiple Levels of Local Governance." In Olowu, D. and Wunsch, J. S. Local Governance in Africa: The Challenge of Democratic Decentralization. Boulder, CO: Lynne Rienner Publishers.

Yeager, R. 1989. Tanzania: An African Experiment. Boulder: Westview Press.

Young, C. 1994. The African Colonial State in Comparative Perspective. New Haven, CT: Yale University Press.

Journal Articles

Acemoglu, D., Johnson, S., and James A. Robinson. 2001. "Colonial Origins of Comparative Development: An Empirical Investigation." American Economic Review, Vol. 91, No. 5, pp. 1369-1401.

Acemoglu, D., Johnson, S., and James A. Robinson. 2002. "Reversal of Fortune: Geography and Institutions in the Making of the Modern World Income Distribution." The Quarterly Journal of Economics, Vol. 117, No. 4, pp. 1231-1294.

Apter, D. E. 1995. "Democracy for Uganda: A Case for Comparison." Daedalus, Vol. 124, No. 3, pp. 155-190.

Caulfield, J. 2006. "The Politics of Bureau Reform in Sub-Saharan Africa." Public Administration and Development, Vol. 26, pp. 15-26.

Cohen, J. M. 1995. "Capacity Building in the Public Sector: A focused Framework for Analysis and Action." International Review of Administrative Sciences, Vol. 61, No. 3, pp. 407-422.

Decalo, S. 1985. "African Personal Dictatorships." The Journal of Modern African Studies, Vol. 23, No. 2, pp. 209-237.

Eisenstadt, S. N. 1959. "Bureaucracy, Bueaucratization and Debureaucratization." Administrative Science Quarterly Vol.4, No.4, pp. 302-320.

Flanary, R. and David Watt. 1999. "The State of Corruption: A Case Study of Uganda." Third World Quarterly, Vol. 20, No. 3, pp. 515-536. 
Fleming, William, G. 1966. "Authority, Efficiency, and Role Stress: Problems in the Development of East African Bureaucracies." In Administrative Science Quarterly, Vol. 11, No. 3, pp. 386-404.

Gertzel, C. 1980. "Uganda After Amin: The Continuing Search for Leadership and Control." African Affairs, Vol. 79, No. 317, pp. 461-489.

Grindle, M. S. and Mary e. Hilderbrand. 1995. "Building Sustainable Capacity in the Public Sector: What Can be Done?" Public Administration and Development, Vol. 15, No. 5, pp. 441-463.

Healy, P. 2001. "Training and Public Sector Reform: An Integrated Approach." Public Administration and Development, Vol. 21, pp. 309-319.

Honadle, G. H. and John P. Hannah. 1982. "Management Performance for Rural Development: Packaged Training or Capacity building." Public Administration and Development, Vol. 2, No. 4, pp. 295-307.

Hood C. 1991. “A Public Management for all Seasons?” Public Administration. Vol. 69, Issue 1, pp. 3-19.

Hood, C. 1995. "Contemporary Public Management: A New Global Paradigm?” Public Policy and Administration, Vol. 10, No.2, pp. 104-117.

Kjaer Anne Mette. 2004. "Old Brooms can Sweep too!: An overview of Rulers and Public Sector Reforms in Uganda, Tanzania and Kenya." Journal of Modern African Studies, Vol. 42, No. 3, pp. 389-413.

Lange, M. K. 2004. "British Colonial Legacies and Political Development." World Development, Vol. 32, No. 6, pp. 905-922.

Lange, M., Mahoney J., and Maththias vom Hau. 2006. "Colonialism and Development: A Comparative Analysis of Spanish and British Colonies." The American Journal of Sociology, Vol. 111, No. 5, pp. 1412-1462.

Langseth, P. 1995. "Civil Service Reform in Uganda: Lessons Learned." In Public Administration and Development, Vol. 15, pp. 365-390.

Larbi, G. 2007. "Between Spin and Reality: Examining Disclosure Practices in Three African Countries." Public Administration and Development, Vol. 27, pp. 205-214.

Leonard, D. K. 1987. "The Political Realities of African Management." In World Development, Vol. 15, No. 7, pp. 899-901. 
Lofchie, M. F. 1978. "Agrarian Crisis and Economic Liberalization in Tanzania." The Journal of Modern African Studies, Vol. 16, No. 3, pp. 451-475.

McCourt, W. and Nazar, Sola. 1999. "Using Training to Promote Civil Service Reform: A Tanzania Local Government Case Study." Public Administration and Development, Vol. 19, pp. 63-75.

Monson, J. 1998. "Relocating Maji Maji: The Politics of Alliance and Authority in the Southern Highlands of Tanzania, 1870-1918." Journal of African History, Vol. 39, No.1, pp. 95-120.

Morris, M. H. and F. A. Jones, 1999. "Entrepreneurship in Established Organizations: The Case of the Public Sector." Entrepreneurship: Theory and Practice, Vol. 24, No.1, pp. 71-86.

Mutahaba, G. 1975. "The Effect of Changes in Tanzania Public Service System Upon Administrative Productivity, 1961-1972." African Review, Vol. 5 No. 2, p. 206.

New Utumishi, Journal of the Tanzania Public Service Reform Programme 2005.

Rijckeghem, C. V. and Beatrice Weder. 2001. "Bureaucratic Corruption and the Rate of Temptation: Do Wages in the Civil Service affect Corruption, and by how much?" Journal of Development Economics, Vol. 65, pp. 307-331.

Rosenbloom, D. H. 1995. "The Use of Case Studies in Public Administration Education in the USA.” Journal of Management History, Vol. 1, No. 1, pp. 33-46.

Semakula Kiwanuka M. 1970. "Colonial Policies and Administration in Africa: The Myths of the Contrasts." African Historical Studies, Vol. 3, No. 2, pp. 295-315.

Sokoloff, K. L. and Stanley, L. Engerman. 2000. "Institutions, Factor Endowments, and Paths of Development in the New World." The Journal of Economic Perspectives, Vol 14, No. 3, pp. 217-232.

Tangri, R. and Andrew M. Mwenda. 2006. "Politics, Donors, and the Ineffectiveness of Anti-corruption Institutions in Uganda." Journal of Modern African Studies, Vol. 44, No. 1, pp. 101-124.

Therkildsen, O. 2004. "Autonomous Tax Administration in Sub-Saharan Africa: The Case of the Uganda Revenue Authority." Forum for Development Studies, Vol. 31, No. 1, pp. 59-88.

Willis, J. 1993. "The Administration of Bonde, 1920-60: A Study of the Implementation of Indirect Rule in Tanganyika.” African Affairs, Vol. 92, No.366, pp. 53-67.

Woodward, P. 1978. “Ambiguous Amin.” African Affairs, Vol. 77, No. 307, pp. 153-164. 
Wubneh, M. 2003. "Building Capacity in Africa: The Impact of Institutional, Policy and Resource Factors.” Africa Development Bank, Oxford: Blackwell Publishing Ltd.

Conference, Discussion, and Working Papers

Bigsten, A. and Andres Danielson. 2001. Tanzania: Is the Ugly Duckling Finally Growing Up? A Report for the OECD Project "Emerging Africa." Uppsala.

Bigsten, A. and Steve Kayizzi-Mugerwa. 2001. Is Uganda an Emerging Economy? A Report for the OECD Project "Emerging Africa."

Bigsten, A. et al 1999. Aid and Reform in Tanzania. Washington, D.C: The World Bank.

Burke, F. G. 1967. "Public Administration in Africa: The Legacy of Inherited Colonial Institutions" Paper presented at the World Congress of International Political Science Association, Brussels, Sept. 18-23.

Denis Ocwich. 2005. “Can Uganda's Economy Support More Districts?” In the New Vision, Monday, 8th August, 2005.

Fjeldstad, Odd-Helge. 2005. "Corruption in Tax Administration: Lessons from Institutional Reforms in Uganda.” CMI Working Paper.

Harvey, C. and Robinson, M. 1995. Economic Reform and Political Liberalization in Uganda. IDS Research Report 29, Brighton: Sussex.

International Monetary Fund. IMF Staff Country Report No. 98/61, Uganda: Selected Issues and Statistical Appendix.

Nunberg, B. 1995. "Managing the Civil Service: Reform Lessons from Advanced Industrial Countries." World Bank Discussion Paper No.204. Washington D.C: World Bank.

Odd-Helge Fjeldstad,. 2005. "Corruption in Tax Administration: Lessons from Institutional Reforms in Uganda." CMI Working Papers.

Robinson, M. 2006. "The Political Economy of Governance Reforms in Uganda." IDS Discussion Paper.

Rwekaza M. et al 2005. The Political Economy of Tanzania. Dar es Salaam.

Schramm, W. 1971. "Notes on Case Studies of Instructional Media Projects." Working Paper for the Academy of Educational Development. Washington, D.C. 
Shepherd, G. 2003. "Civil Service Reform in Developing Countries: Why Is It Going Badly? A Paper Presented at the $11^{\text {th }}$ International Anti-Corruption Conference held in Seoul, Republic of Korea, 25-28 May 2003.

Therkildsen, O. 2001. "Efficiency, Accountability, and Implementation: Public Sector Reform in East and Southern Africa." Geneva: UNRISD Programme Paper 3.

The World Bank 2006. Public Sector Reform and Capacity Building. Report No: 35615 TZ.

World Bank. 1993. A Governance Approach to Civil Service Reform in Sub-Saharan Africa. World Bank Technical Paper Number 225, Washington D.C.: World Bank, Africa Technical Department.

World Bank. 1994A. Managing the Civil Service: Reform Lessons from Advanced Industrialized Countries. World Bank Discussion Paper 252, Washington D.C.: The World Bank.

Government Publications

Government of Uganda, Inspectorate of Government. 2003. Final Report: Second National Integrity Survey. Kampla: K2-Consult Uganda Limited.

Government of Uganda, Joint Annual Review of Decentralization 2004. Ministry of Local Government, Kampala.

Government of Uganda, Ministry of Education and Sports. 2004. Enhancing UPE: A Stakeholders Handbook. Kampala.

Government of Uganda, Ministry of Finance. 2004. Uganda Capacity and Performance Enhancement Project (CAPEP). Kampala

Government of Uganda, Ministry of Public Service. 1993. Civil Service Reform Status Report 1. Kampala.

Government of Uganda, Ministry of Public Service. 1994. Civil Service reform Program Status Report 2 October 1993-February.

Government of Uganda, Ministry of Public Service. 1994. Management of Change: Content, Vision, Objectives, strategy and Plan. Kampala: Uganda Printing and Publishing Corporation.

Government of Uganda, Ministry of Public Service. 1996. Civil Service reform Program Status Report 8 January 1 - March 31. 
Government of Uganda, Ministry of Public Service. 1997. Public Service Reform Programme 1997-2002. Kampala.

Government of Uganda, Ministry of Public Service. 1999. Public Service Reform Programme: Report for the Year 1999. Kampala.

Government of Uganda, Ministry Of Public Service. 2001. Medium Term Public Service Pay Reform Strategy. Kampala.

Government of Uganda, Ministry of Public Service. 2002. Public Service Reform Strategy 2002-2007. Kampala.

Government of Uganda, Ministry of Public Service. 2003. Public Service Reform Programme: Annual Report for the Financial Year 2002/2003. Kampala.

Government of Uganda, Ministry of Public Service. 2005. An Update of the Public Service Pay Reform Strategy. Kampala.

Government of Uganda, Ministry of Public Service. 2006. The Republic of Uganda Public Service Training Policy. Kampala.

Government of Uganda, Ministry of Public Service. Uganda Civil Service Reform Programme Status Repot 9, Kampala.

Government of Uganda, MPS Payroll Monitoring Unit. In Public Service Reform Strategy 2002-2007, Ministry of Public Service.

Government of Uganda, Public Service Reform Program Annual Report for the Financial Year 2002/03. Kampala.

Government of Uganda, The law and Development Partnership Limited. 2004. "A Study on Remuneration and Pay Policies for Public Service Institutions and Government Agencies." Kampala.

Government of Uganda. 1995. The Uganda Constitution.

Government of Uganda. Ministry of Public Service. 1996.Uganda Civil Service Reform Programme: Status Report 10. Kampala.

Government of Uganda. Report, Policy and Plan for the Development of Human Resources in the Public Service of Uganda.

The Public Service Review and Reorganization Report, 1989, Kampala: Uganda Printing and Publishing Corporation. 
The Public Service Review and Reorganzation Report, 1989, Kampala, Uganda.

The Uganda Protectorate. 1936. The Uganda Agreement - 1900. Laws of Uganda.

The United Republic of Tanzania, Ministry of Education. 2004. Medium Term Strategic Plan, 2004 -2007. Dar es Salaam.

Uganda Local Administration Act 1967. Entebbe: Government Printer.

Uganda Protectorate. (1939). Native Administration: Note by the Governor. Entebbe: Government Printer.

Uganda Protectorate. 1936. An ordinance to Make Provision for the Powers of and Duties of African Chiefs and for the Enforcement of African Authority. Laws of Uganda.

United Republic of Tanzania, MOF, 1996/97 Budget.

United Republic of Tanzania, President's Office - Public Service Management. Public Service Reform Programme Phase II 2008-2012. Dar es Salaam.

United Republic of Tanzania, President's Office - Public Service Management. 2004. Annual Progress Report 2003/04. Dar es Salaam.

United Republic of Tanzania, President's Office - Public Service Management. 2005. State of the Public Service Report 2004. Dar es Salaam.

United Republic of Tanzania, President's Office - Public Service Management. 2008. PSRP Phase 1 End of Programme Report: A Summary of Results 2003-2007. Dar es Salaam.

United Republic of Tanzania, President's Office-Public Service Management. 2000. The PSRP 1 Medium Term Strategy. Dar es Salaam.

United Republic of Tanzania. 1969. Tanzania Second Five-Year Plan for Economic and Social Development, 1969-1974. Dar es Salaam: Government Printer.

United Republic of Tanzania. 1969. Tanzania Second Five-Year Plan for Economic and Social Development, 1969-1974. Dar es Salaam: Government Printer.

United Republic of Tanzania. 1998. Policy Paper on Local Government Reform. Dar es Salaam.

United Republic of Tanzania. President's Office - Civil Service Department. 1999. Civil Service Reform Programme Implementation Status Report (1993 - 1999). Dar es Salaam. 


\section{Web Sources}

Buganda Kingdom. www.buganda.com

Bunyoro-Kitara Kingdom. http://www.bunyoro-kitara.com

Inspector General of Government. www.igg.go.ug

Transparency International. www.transparency.org. 


\section{APPENDIX 1 INTERVIEW SCHEDULE}

Date:

Location:

Start time:

End time:

Interviewee Demographics
a) Name:
b) Gender:
c) Position/Rank:
d) Years in the Public Service:
e) Part of the PSRRC:

\section{Major Interview Questions}

1. What are the major driving forces of the Civil Service Reform Program?

2. What has been the effect of the reform program on the size of the civil service?

3. What has been the effect of the reform program on salary structure?

4. Is there an optimum-target salary structure? If so, on what is it based?

5. What is the effect of the current salary structure on worker motivation?

6. What has been the effect of the reform program on capacity building?

7. What has been the effect of the reform program on ethics and accountability?

8. In your view, since the reform was initiated, is the civil service a better performer?

9. What are the major challenges facing the reform program? 


\section{APPENDIX 2 SUMMARY OF THE PSRRC RECOMMENDATIONS}

1. The Uganda Planning Commission should be reactivated and be given a more focused planning authority

2. The Ministry of Planning and Economic Development should be the Secratariat of the resuscitated Uganda Planning Commission.

3. Given the role that the Public Service plays in the development process, there is a need for an expanded and strengthened role of the Ministry of Public Service and Cabinet Affairs within an appropriate Act of NRC to facilitate effective management of the affairs of the Public Service.

4. The recommended "Agenda for Action" should be implemented soon in order to infuse a new results-oriented management ethos and re-create a Public Service that is well trained, disciplined, motivated, effective and efficient.

5. A new concept of results-oriented management style should be adopted in which the following management practices are adopted: Project Management, Management by Objectives and Program and Performance Management.

6. A unified structure which embraces all the posts in the Civil Service from the lowest to the highest and provides equal opportunity for every officer to advance to the highest post in the service irrespective of his or her discipline should be instituted.

7. Government should put in place a service that is manned mainly by professional and specialized personnel and not, as at present, predominantly by generalist administrators and functionaries.

8. The New Era Public Service should recognize the distinction between career civil servants and politically appointed officers.

9. The Service should recognize the different roles of Secretary to the President and Head of the Civil Service.

10. All members of the Public Service should subscribe to and uphold a Code of Conduct.

11. The establishment of new Ministers should be vetted by the Legislature and in this process the Legislature should be availed a clear statement of mandate showing in broad terms the areas of Government activities for which the new Ministry should be responsible.

12. Government should follow through and decisively adopt a pure Presidential system for the governance of the country.

13. On appointment of Legislators as Ministers they should resign their seats in Parliament in order that they concentrate on executive duties.

14. Each Ministry should have one Cabinet Minister and, if the work load justifies, a Minister of State or a Deputy Minister to supervise critical functions.

15. On-going consultations should be re-oriented to embrace the much bigger task of rationalizing government functions; and their reports should be submitted to and implemented by the Administrative Reform Commission.

16. Government should set up a permanent body to scrutinize and keep under review its involvement in the various fields in which it is presently engaged with a view to keeping the field as narrow as possible. 
17. The process of decentralization should involve devolution of powers direct to District Authorities; and all Regional Offices except those of Uganda Police Force should be formally abolished.

18. The elected RC 5 Chairperson should become the District Chairman (DC) and the Political Head of the District.

19. The District Executive Secretaries should cease to be called "Secretaries". They should instead be called Directors.

20. The RC 5 executive should be composed of nine people.

21. The District Development Committee should carry out its functions as spelt out in its Statute, with the technocrats taking over from the elected representatives whose number should be trimmed down.

22. Government should set up a Committee of experts to advise on financial decentralization.

23. Political Parties whether in a single party or multiparty system should be financed from Public Funds even if the interests of the party are assumed to be co-terminus with those of the majority of the population.

24. The NRM, as such, should not give any directives to the Civil Service except through the Cabinet and Legislature.

25. Career public officers should not participate in partisan politics.

26. Ministries as structures of the Public Service should be streamlined and reduced to the optimal number of 21 Ministries.

27. The Administrative Reform Commission should regard the rationalization as top national priority.

28. The Ministry as the largest unit of government with the responsibility to carry out similar activities in pursuit of common interrelated policies and programmes should be under the clear professional direction of a single manager in control of the required resources deployed to achieve public policies and objectives.

29. The activities of government should be pursued in hierarchical levels of specified duties and responsibilities.

30. The nomenclature of structural entities of the Public Service should be standardized and uniform, functionally descriptive titles be used for similar structures in the Public Service.

31. In setting up new public organizations, a bottom-up analysis of demand for the services should first be undertaken.

32. Decisions regarding civil service structure, recruitment and assessment of performance should be so determined as to optimize achievement of results, increased output, and improved performance.

33. The class structure of the Public Service should be abolished and should be replaced with an integrated results-oriented management team approach.

34. If the structure of the Public Service is to be more responsive to the needs of the majority of Ugandans, it should be moved closer to the people; the operational structures should also be moved to the rural areas in order to achieve development.

35. Each Ministry should seek to achieve the objectives of a public policy through the program of a five year rolling corporate strategic plan. 
36. Assessment of Public Officers and all Public Units should be based on clearly stated anticipated outputs or results.

37. Systems of zero-based budgeting and spending linked to objectives and outputs should be adopted and designed in such a way as to take advantage of the introduction of Results-Oriented Management with a view to decentralizing the system and giving managers more responsibility over resources for the achievement of results.

38. Government should review its role in the various sectors of socio-economic life with a view to determining those it performs best and those it is ineffective in performing.

39. Measures should be taken to reestablish a sound mechanism of establishment audit and control backed by the necessary resources.

40. Government should consider implementing measures which are critical to improved productivity of public employees.

41. Clear policies and mechanisms should be established regarding organization of Manpower Planning for the Public Service.

42. The more productive, the smaller will be the workforce needed by the Public Service. To effect changes in Manpower productivity would require skills improvement programs through training, and higher employee motivation through an appropriate compensation package, recognition of good performers together with appropriate technological innovations.

43. The expansion of the public service should occur only where

(a) there is properly formulated extra workload to perform; and

(b) it is financed with real resources generated from internal economic activity.

44. Measures to effect downward adjustment (i.e. reduction) in the size of the current public service should be considered.

45. The share of the wage bill in the overall Government expenditure should be increased from the present $13.1 \%$ to at least $25 \%$.

46. Identify type of staff who are deemed to constitute the "overdue leavers" group who should be laid off before the launching of the retrenchment exercise.

47. Poor performers or corrupt staff should be laid off; and be paid whatever they are legally entitled to receive without delay.

48. Government should launch a selective recruitment and/or training of qualified staff who can competently fill the vacant critical positions.

49. The process of selecting the staff for retention or retrenchment should be started from the apex of the public service structure and proceed gradually to the base.

50. An independent body, to be known as "The Implementation and Monitoring Board", should be appointed.

51. The selection criteria to be used will be possession of the minimum qualifications required, on the one hand, and performance record of the candidate under consideration.

52. As part of the separation agreement between retrenchees and Government, recipients should be required to sign a clause renouncing any further claims on Government before they receive their compensation package. 
53. Government should take deliberate steps to give up some of its current functions to the private sector.

54. A Department of Manpower Planning and Development should be created in the Ministry of Public Service and Cabinet Affairs.

55. The Department should have the following Divisions, each headed by a Deputy Director:

(i) Manpower Planning

(ii) Manpower Development and

(iii) Manpower Information.

56. Government should consider establishing, in due course, an integrated Ministry of Human Resources.

57. The continued isolation of the Ministry of Public Service and Cabinet Affairs at Entebbe is becoming increasingly anomalous: and consideration should now be given to having it relocated in Kampala.

58. In the interim, the Manpower Planning Department within the Ministry of Planning and Economic Development should be renamed the Department of National Manpower Planning and be the Secretariat to the National Manpower Council.

59. The Department should be responsible for the nation's entire human resources planning, developing and utilization.

60. Government, in general, should increase the proportion of public financing to education.

61. The Ministry of Labour should make urgent reforms in Labour Administration.

62. The National Manpower Council should provide policy guidelines for the development and integration of the informal sector employment programme with the overall National Development Plan.

63. Measures recommended to improve conditions of Ugandans currently in the country should be implemented selectively and simultaneously while implementing measures aimed at assisting Ugandan professionals abroad.

64. Professional in-service goal-oriented training should be encouraged and enhanced, to increase departmental productivity which, in turn, should determine promotional possibilities of individual employees.

65. The Central Scholarships Committee should be under the Ministry of Planning, along with the other three Committees of the National Manpower Council: in order to promote harmony and coordinated management of training in the Public Service.

66. The National Curriculum Development Centre should be linked with National Manpower Council in order to link formal academic education with in-service professionals and department training.

67. The "Cabinet Affairs" functions of the Ministry of Public Service should be transferred to the office of the President.

68. The Ministry should be re-named "Ministry of Public Service".

69. The powers of appointment, promotion, and discipline should remain with the Public Service Commission, but extensive delegations should be made to Ministries and Districts. 
70. Both the Constitution and the Public Service Act should be amended, to reflect the specific recommendations of the Commission.

71. In view of the existence of separate Service Commissions for the Judiciary, the Police, Prisons, and Teachers, the Public Service Commission should be renamed the Civil Service Commission.

72. Merit-based recruitment through open competition (rather that political identification) will be absolutely necessary.

73. The Public Service should insist on well-defined job descriptions, specifications and schemes of service pre-deposited with the Ministry of Public Service and Cabinet Affairs and the Public Service Commission.

74. The Civil Service Commission should enhance the use of examinations in recruitment as far as it is applicable on selective basis.

75. Minimum entry requirements should be retained and renewed constantly in response to development changes.

76. All presidential and Ministerial appointments in the Public Service should be on the advice of the Civil Service Commission, or such Commission as is responsible for the service concerned.

77. For Parastatal Bodies, such appointments should first be cleared by a Select Committee of the Legislature on political appointments, which should reserve the right to call the proposed candidates for interview as deemed necessary.

78. Career guidance to schools should immediately be revived, reconstituted and directed to the manpower demands of the country.

79. An expert consultancy group should be contracted to draw up different schemes of service for all cadres in the Public Service.

80. The existing rules that govern the behavior of public officers, which form the basis of a code of conduct, be reviewed, updated, and bound in a small handbook or pamphlet for the Service.

81. The IGG's Statute should be amended to delete the "any other functions" clause.

82. The post of IGG be made a constitutional post chargeable on the Consolidated Fund.

83. The IGG should be accountable to and report to Parliament.

84. Great care should be exercised in scrutinizing the staff of the IGG's office both before and after recruitment. (Their educational, career and family background as well as other character and social habits should be critically examined).

85. The office of Ombudsman should be created as a separate autonomous institution.

86. Each department should formulate a three to five year corporate plan through the widest possible participation of its key employees with a view to generating annual action programmes which ought to be the only basis for annual budget requests. Quantifiable outputs or targets evolved through such action programmes should be the principal basis for performance appraisal of individuals, units, sections, divisions, departments and ultimately, Ministries.

87. Each Ministry be required to formulate a corporate plan; and that once approved by Cabinet, pressure be exerted on Ministries and their officials to make it the principal control mechanism. 
88. It is imperative that there is always agreement between the Treasury and each individual Department or Ministry on the scope of proposed department or Ministerial expenditure outlays and that Cabinet is advised accordingly and deliberates on the agreed figures well in advance of submission of the budget proposals to Parliament.

89. Disciplinary action should be taken against Permanent Secretaries and Heads of Departments who knowingly purport to execute programmes when it is already obvious that they are bound to flounder on the way because of inadequate resources, especially when this is coupled with failure to take timely remedial action.

90. Budget requests and annual lump sum appropriations be broken down into smaller disbursement units over the financial year and be tailored to planned user requirements.

91. Budgets be recast in programme format for consideration by Parliament and that passage of the appropriations be construed as performance contracts subject to periodic assessment for conformance with the desired outputs.

92. Establishment of a Standing Appropriations Committee of Parliament to examine all budget requests and supplementary estimates in greater detail than is presently feasible in severely time-constrained floor debate which is often confined to selected Ministries.

93. The re-introduction of the ex-chequer system of releases of funds to Ministries in its entirety but in two stages: bimonthly and quarterly.

94. Writing and submission of monthly and quarterly accounts to provide for timely political review of on-going programmes in every ministry.

95. The Inspectorate Division of the Ministry of Finance should be disbanded and qualified and suitable staff redeployed as internal auditors in the various internal audit units, reporting directly to the Director-General (Permanent Secretary), which should be set up in every Ministry, in pursuance of the above objectives.

96. The Public Accounts Committee be expanded in size and scope and be provided with a Secretariat that matches the task to enable it to exercise a watchdog function over current expenditure of public funds throughout a current financial year, and that in addition to the annual audited reports, it should receive and act on quarterly unaudited statements of expenditure.

97. Government should establish an external efficiency audit team to probe into Value for Money practices or lack of them in the various units of the Public Service.

98. Complaints be channelled through District Petitions Committees to avail citizens and their representatives of the opportunity of public hearings to accost nonperforming public servants with queries and accusations.

99. The National Resistance Council re-establishes transparent procedures for raising and answering questions.

100. All monies voted for the Office of the Minister and his deputy in each Ministry be channelled through the Office of the Prime Minister or Vice-President for control and initiation of action to the Treasury for supplementary estimates if warranted; in order to leave free the rest of the Ministry's funds to carry out the 
Ministry's programmes unencumbered by the needs and whims of the Minister and his deputy.

101. The function of Records and Information Management should be given the recognition it deserves through the appointment, without further delay, of a suitable Head to lead the Unit responsible for it within the Ministry of Public Service and Cabinet Affairs, to define a career for Records Officers.

102. Officers of all cadres throughout the Services be sensitized about the importance of records and records systems.

103. Computers should be acquired to replace manual records systems.

104. A special building should be constructed to house the National Documentation Centre, the national Information System and the National Archives.

105. The National Archives should be moved from the office of the President and placed under the administration of the Commissioner for Records.

106. Libraries should cease to be under the Department of Community Development and be more appropriate put under NIS set-up.

107. Where it is available, Ministries and Departments should take advantage of the ISD facility and the secret codes. In the other areas, Ministries should install PABX switchboards which facilitate programming to regulate connections from extension as may be required. The installation of private direct lines should also be kept to the very minimum to limit abuse.

108. Proficiency in the use of the "Minute Systems" and other "paper work" submissions, including preparation of Cabinet Memoranda must be a necessary possession of all aspirants to senior Government positions. It should be the responsibility of senior officers to guide their subordinates in acquiring these skills.

109. The Courier Service between Kampala and Entebbe should be improved to previously efficiency levels - privatized preferably and bicycles provided for Office Messengers to perform the "messengerial" duties more effectively.

110. The on-going rehabilitation and expansion of the media of mass communication, especially radio and television, is commendable since these are channels through which information can be passed to the majority of the population.

111. The staff should be enabled to purchase and maintain their own appropriate vehicles on loan and at subsidized (co-ownership) rates.

112. The standing orders should not include such easily "dated" details as rates of salaries and other payments. These should be published in circulars from time to time.

113. The standing orders, which should include all rules and regulations, should be published in small separate volumes, each volume covering a particular subject. The volumes should be in loose leaf binding to facilitate the insertion of amendments.

114. All rules and regulations should be reviewed by a small hi-powered committee.

115. The Fight against corruption will be hard and protracted. It is a war that must be fought and won. Remedial actions will have to be instituted on various fronts. 
116. Government and all people in leadership positions must be seen to be openly and resolutely against corruption.

117. Wherever possible staff should be encouraged to open personal bank/savings accounts at their stations.

118. A leadership code of conduct should be established immediately for all public office holders both Political and Public Servant.

119. The NRC should establish a committee to review backgrounds and qualifications before they clear candidates for Senior Public/Political Office.

120. Vigorous efforts should be made to strictly enforce all anticorruption laws, rules and regulations.

121. To ensure quick but fair trials, the NRC be asked to establish a special Anticorruption Tribunal.

122. Corruption is a serious crime; therefore the punishment must be made to fit the crime.

123. As a first step in the right direction, Government should pay a Minimum Living Wage to its employees.

124. The second phase should include the paying of a Living Wage.

125. An appropriate Wage should be paid during the third phase.

126. Finally, the entire service will be brought to adequate and stable pay commensurate with salaries elsewhere in the region - PTA average.

127. This is a critical and complex programme which requires in-depth annual reviews.

128. With effect from 1 July 1991, on the assumption that Government implements our recommendations on salaries, all Allowances payable to Government be abolished except for those that are duty-facilitating or compensatory for extra duties performed.

129. All responsibility Allowances be abolished for the entire Public Service.

130. Allowances given by Donors as incentives should be abolished in principle with effect from $1^{\text {st }}$ July 1991, except for expenditure intended to improve work environment, training, travel on duty etc.

131. The National Housing Corporation should be provided with the necessary capital to build low cost houses and sell them to Civil Servants among others. The Government should act as a guarantor for the mortgage.

132. Government should inject money into Housing Finance Co. of Uganda so that it can implement the loan scheme.

133. The management of garbage collection in urban centres should be privatized.

134. A special campaign be planned to include a maintenance culture and respect for public utilities among public officers.

135. Government should reorganize and re-order its priorities to improve medical facilities in general; after which it can consider shedding some of the responsibilities of providing free or heavily subsidized medical treatment.

136. Government should provide free medical treatment for the time being until such a time that the Civil Service is fully rehabilitated and adequately remunerated, to enable its members to meet the cost. 
137. Government should divest itself of having, in principle, with a view to relinquishing, the responsibility of provision of houses to its employees.

138. Government should immediately put in place schemes designed to assist Civil Servants to build their own houses, through the provision of site and service schemes, low-interest loans, and payment of an appropriate housing allowance in lieu of housing, pending payment of an appropriate wage.

139. Government should, with the help of technical assistance, launch a survey of the existing stock of Government houses, ascertain their physical location and condition, and estimate their market value, so that they are sold off for value.

140. Government, when it eventually divests itself and settles on selling the pool houses, the site of some of these properties being in high value area, and on planned plots, and of special architectural design, these factors should be taken into consideration in valuation before sale.

141. The proceeds from the sale of pool houses should be put in a revolving fund to assist other Civil Servants to build their own houses.

142. The Housing Finance Co. of Uganda should be capitalized and given the mandate to implement a Government loan scheme for Civil Servants.

143. The present concept of the pension as a superannuating arrangement should be abandoned and replaced by a contributory pension scheme where both employer and employee contribute towards the employee's pension on a monthly basis. It is suggested that the employee contribute $7 \frac{1}{2} \%$ of his basic monthly salary, and the employer, i.e., the government, pays the equivalent of $15 \%$ of his basic salary.

144. The Pensions Fund be divorced from the Consolidate Fund and be administered on purely business principles to generate profits from which pensioners can draw further benefit.

145. Technical assistance should be sought to advise on the best way to convert from the present superannuation schemes to the proposed contributory scheme.

146. Technical Assistance should be sought to advise on the optimum levels of contribution by employers and employees; the optimum rate of interest to be paid on the collections, and the participation formula for the members to share in the profits of the proposed bank/investment house.

147. Technical Assistance should be sought to draw up the charter of the proposed bank/investment house, and;

148. Offer such other advice as may be deemed pertinent in the light of the experience of other similar ventures elsewhere.

149. To enhance the independent, impartial and non-partisan character of the Judicial Service Commission, its membership should be explained.

150. The President should nominate the Chief Justice, the Deputy Chief Justice and the Principal Judge, and the Legislature should have the power to approve or reject the nomination.

151. All Judicial officers should be paid an "appropriate wage".

152. The Judicial Service should be considered as vital to the Rule of law, to which the government is committed, and should be given enough funds to run the service. 
153. RC 3 Court members in each District should be elected at the same time.

154. Quite apart from their basic legal qualifications, all Magistrates Grade 1 should be required to obtain a Diploma in Public Administration or Personnel Management from the IPA or an equivalent qualification before being considered for further promotion.

155. The Government should pay particular attention to the operational problems of the Judiciary in contributing to delays in proceedings with a view to their elimination so that the unintended perpetual denial of Justice is brought to a stop.

156. That the law reform commission now in the process of being established by law, be tasked to start with examining the Laws in our Statute book with a view to advising the legislature on appropriate action regarding those laws found to be irrelevant or unjust.

157. The rules providing for appointment of Court Brokers should be reviewed to provide proper screening of applicants before they are licensed.

158. The Coroners Inquests should be re-activated.

159. The enactment of a Judicial Service Act which should contain a Code of Conduct for Judicial officers. The Minister of Justice and the Chief Justice should set up a Committee to draw up comprehensive Code of Conduct for this purpose.

160. The Uganda Police Force should be organized and administered in accordance with the Police act, which should be overhauled to loosen the present tight control by the Minister of Internal Affairs.

161. There should be created a Police Council, a Police Service Commission and a Police Service Committee to manage and administer all the affairs of the Ugandan Police.

162. A separate Police Tender Board be created, but with linkage to keep it under the general surveillance of Central ender Board.

163. The Police Force should have the power to control their Recurrent and Capital Development funds.

164. The Uganda Police Force should now shed the Fire Service function, which should now be a separate National Fire Service.

165. Both the Police Force and the Local Administration Police Forces should be integrated into one Ugandan Police Force.

166. That the Inspector General of Police be appointed by the President on the advice of the Police Council.

167. In the interest of the Police Force, steps should be taken immediately to appoint a substantive Inspector-General of Police and a Deputy Inspector-General of Police.

168. The Uganda Police College should be strengthened to provide specialized training for the CID staff.

169. The Special Brach, the Internal Security Organization (ISO) and the External Security Organization (ESO) should be rationalized into one integrated, welltrained, well-equipped and highly professionalized organization to avoid unnecessary duplication of functions and the dissipation of scarce resources that 
invariably occurs when rival organizations are set up to perform the same general functions.

170. Steps should be taken to revert the Airwing to the Police Force.

171. Government should take steps to rationalize the role of the LDF by enacting a law stating their mandate, powers and limits and prescribing other matters relating to recruitment, training, role and discipline of the Force.

172. The Immigration Department should be properly equipped for the tasks of the department, including the Police Force and equipment, stationary, and trained personnel.

173. Necessary steps be taken, as a matter of urgency, to ensure that the Army leaves internal policing to the Uganda Police Force and concentrates on protecting the country from external aggressors.

174. The function of Inspection, Registration and Licensing of all motor vehicles should be rationalized in one Ministry; and the Ministry to assume this responsibility should be the Ministry of Transport.

175. The three Codes of Conduct be unified and up-dated into one Code of Conduct, which should be part of a modernized Police Act which should be enacted to implement all recommendations that may be accepted and any other modern innovations the government may see fit.

176. There should be a Prisons Council, a Prisons Commission and a Prisons Service Committee.

177. In order to enhance efficiency and promote uniform standards, the Prisons Service as a whole should be integrated.

178. A separate Tender Board for the Prisons Service should be established.

179. A performance audit Unit should be established within the Prisons personnel division.

180. A Prisons Complaints Bureau should be established.

181. A separate Health Division should be established in the Prisons Service.

182. To ensure fullest accountability, commercial auditing should be introduced for the Prisons Enterprises Sector.

The Ministry of Education should take the following steps:

183. To encourage the grading system.

184. To institute efficiency audit of individual teachers through institutional and inspectorate systems to facilitate promotion of deserving teachers.

185. To encourage promotion of teachers in the classroom;

186. To facilitate mobility of teachers and administrators between the classroom and administration; and

187. To see to it that the grading of technical and business education teachers is implemented alongside that of academic education teachers.

188. Administration of teachers' pensions should be decentralized to sectional level in the Ministry of Education to ease the suffering of the large numbers of teachers inconvenienced by the current centralized system of pension administration. 
189. Teacher's salaries and allowances should similarly be decentralized to District level to minimize the administrative costs involved in each school having to come to Ministry Headquarters to collect.

190. The Ministry of Education should devise a machinery to ensure that PTA funds are maximally utilized, by requiring that teachers do teach in one school.

191. In order not to unduly embarrass or over-burden poor parents, the Ministry of Education should exercise some degree of control over the frequency and magnitude of PTA levies by involving the Boards of Governors and Military Headquarters in the decision making.

192. The Ministry of Education should ensure that where part time teaching is absolutely necessary, the rules and regulations governing it are strictly observed.

193. Government should look more seriously into the problems of fringe benefits for teachers with a view to making the profession more attractive.

194. The Education act should be amended to make the span of the CEO's authority more manageable.

195. The CIS's current role should be reviewed to make him independent of the CEO such that he assumes his traditional role of both assessor and auditor of the education system more effectively.

196. The Board of Governors' rules and authority should be reviewed so as to make BOGs effective managers of the Educational System.

197. The TSC should be accorded more authority in the personnel management of the Teaching Service by making CEO and CIS responsible to the TSC.

198. The interests of the teachers should be represented at both TSC and BOG level.

199. TSC should lay down these qualifications as minimum requirements for future appointments to Inspector and education Officer posts in order to accord the posts the professional status they have long lacked.

200. To enhance the teaching of Science, the Ministry of Education should identify men and women to be offered local and overseas training so they could form the nucleus of a corpus of future Trainers at potential Science Colleges in the country.

201. Teacher Centres should be refurbished with the necessary teaching (particularly Science) equipment so as to train teachers effectively.

202. Government should take a bold step of inducement by awarding three salary increments to Grade III teachers on first appointment.

203. Attempts should be made to make training facilities as attractive as possible.

204. Promising teachers should be availed the opportunity of training in Public Administration and management Skills.

205. Educational administrators should be exposed to similar in-service courses at IPA and elsewhere.

206. Proper schemes of service should be prepared for all teachers incorporating training in management techniques.

207. The Vice-Chancellor and the Deputy Vice-Chancellor should be ex-officio members of the University Appointments Board. 
208. Relevant Technical/experience qualifications for membership of the Appointments Board should be stipulated.

209. The relationship of the Appointments Board to the University Council should be that of a Committee of the Council.

210. The duties/responsibilities of the Chairman of the Appointments Board should be spelt out, to guide his relationship with Council and Senate.

211. The powers of the three subordinate Committees of the Appointments Board (Junior/Technical/Secretarial-Clerical) should be clearly defined and regulated.

212. The Makerere University Act should be amended.

213. That a position of Deputy Vice-Chancellor (Administration) be created to make for a more balanced structure at the top.

214. The Vice-Chancellor shall be an eminent citizen.

215. A National Council on Higher Education be established to coordinate and generally to spearhead the development of Higher Education in the Country.

216. The functions and objectives of institutions of higher learning should be more broadly conceived.

217. Steps should be taken to reform the legal framework under which the institutions of higher learning are operating. The reform exercise should involve all the parties concerned, including teachers and student representatives. The objective should be to streamline management of, and human relations within, institutions of higher learning.

218. The Treasury should take steps to understand the nature and structure of the financial needs of the institutions it sustains.

219. Government should take decisive steps to rehabilitate the physical infrastructure of institutions of higher learning.

220. Institutions of higher learning should be granted legal authority to borrow or otherwise raise money for self-financing.

221. Plans for the third "University of the North" should be shelved indefinitely.

222. Mbarara University should be kept relatively small (both in numbers and range of courses) for the foreseeable future, since the economy cannot support another full-blown University.

223. Encourage training and educational institutions to develop and offer practical courses relevant to entrepreneurship.

224. Encourage cooperation, including joint ventures between local investors.

225. Assistance should be given to development banks for mobilizing resources for long term financing of private sector activities.

226. Develop incentives that would encourage private sector development of small scale industries in the rural areas.

227. Develop means of protecting the local markets without discouraging competition.

228. Identify and remove administrative inefficiency and delays, excessive monitoring/control and over-regulation by public agencies.

229. Small scale industries should be promoted by Government. 
230. Greater recognition should be given to the important role the informal sector plays in employment by devising policies which would facilitate growth and organization in an attempt to regularize this sector as a source of revenue.

231. The reform of the Civil Service should be accompanied by a decision to shed those activities heretofore provided by the Government which can be performed by the private sector.

232. A "one stop business" centre should be established for new businesses to assist with the licensing and registration, determination of viability of proposals, provision of information on domestic and export markets, etc.

233. Applicants for licensing should have access to a government "Ombudsman" to complain about problems encountered in this process.

234. Local authorities should be permitted and encouraged to assist in facilitating the introduction and growth of the private sector in their respective areas.

235. The rate of corporate tax (45 percent, $1989 / 90$ and 40 percent, 1990/91) should be further reduced to generate increased growth. This should be staggered in favor of enterprises providing more economic growth and development for the nation.

236. Government should formulate policies which would liberalize the development of a diversified, competitive financial market with a variety of debt and equity instruments and promotion of different kinds of variable institutions with a wide range of financial instruments for savers and investors.

237. Greater incentives should be devised for the export-orientated enterprises with complementary incentives for those exporting end-products with value added.

238. Government should develop a coordinated national plan for water, roads, energy and communication from the comprehensive five year plan (1990-95) with projection of cost and implementation phased over that time period.

239. Additional business technical training could be made available if other institutions capable of offering and training were rehabilitated and their curricula expanded.

240. Separation packages for the redeployed civil servants to be computed.

241. Setting up a credit facility to finance economic projects to be promoted by the redeployed civil servants.

242. Setting up a small institution to manage the redeployment of civil servant.

243. Increasing budgetary outlays to improve the remuneration of civil servants.

244. Procuring adequate and appropriate tools and equipment to improve the operation of civil servants, and

245. Assistance in capacity and institution building to revamp and strengthen the Ministry of Public Service.

246. Getting rid of loss-making parastatal corporations.

247. Reducing the wage bill by elimination "air supply" practices, ghost workers, and other staff not essential in development management.

248. Mobilizing the population to undertake community-level development projects using voluntary labour and in-kind contributions.

249. Introducing user charges at affordable rates for publicly provided services where this is ethically acceptable and politically feasible. 
250. Centralizing the Procurement of common-user items in order to take advantage of lower prices for bulk purchase, and to minimize the possibility of nonaccountability and abuse associated with many small buyers.

251. Reducing the need, size of delegations, frequency and rates of allowance for official travels outside Uganda.

252. Minimizing loss of Government funds on vehicle maintenance, by rehabilitating Government Central Mechanical Workshop to maintain Government vehicles, backed up by tighter supervision and control, as well as improved remuneration of the staff therein.

253. Laying off the bulk of group employees and instituting stricter control over, and accounting for, activities requiring the use of group employees.

254. Using the development plan as a basis for the annual budget, and releasing funds from the Treasury only for activities on programmes and projects included in the development plan.

255. Eliminating Government Ministries and Departments and staff therein whose functions duplicate others, or which are not within the scope of the accepted functions of Government. 


\section{APPENDIX 3 LIST OF AUTONOMOUS AND SEMI-AUTONOMOUS PUBLIC AGENCIES IN UGANDA}

Capital Markets Authority

Civil Aviation Authority

Coffee Development Authority

Cotton Development Authority

Dairy Development Authority

Electricity Regulatory Authority

Engineers Registration Board

Gulu University

Inspector General of Government

Inter University Council

Joint Clinical Research Centre

Kyambogo University

Law Development Center

Makerere University

Makerere University Business School

Management Training and Advisory Centre

Mbarara University

National Agricultural Advisory Services

National Agricultural Research

Organization

National Chemotheraputic Laboratory

National Council of Science and

Technology

National Council of Sports

National Drug Authority

National Environmental Management

Authority

National Forestry Authority

National Planning Authority

National Roads Safety Council

National Social Security Fund

National Women's Council

National Youth Council

Nommo Gallery

Non-performing Assess Recovery Tribunal

Plan for Modernization Agency

Population Secretariat

Professional Council

Public Libraries Board

Road Agency Formation Unit

Tax Appeals Tribunal
Transport Licensing Board

Uganda National Health Research

Organization

Uganda Bureau of Statistics

Uganda Export Promotion Board

Uganda Industrial Research Institute

Uganda Investment Authority

Uganda Management Institute

Uganda National Bureau of Standards

Uganda National Examination Board

Uganda National Institute for Special

Education

Uganda Revenue Authority

Uganda Tea Development Authority

Uganda Tourism Board

Uganda Travel Bureau

Uganda Trypanosmiasis Control Council

Uganda Virus Research Institute

Uganda Wild Life Authority

Urban Water Authorities

Wild Life Education Centre

Amnesty Commission

Constitutional Review Commission

District Service Commissions (80)

Education Service Commission

Electoral Commission

Equal Opportunities Commission

Health Service Commission

Judicial Service Commission

Law Reform Commission

Local Government Finance Commission

Parliamentary Commission

Public Service Commission

Uganda AIDs Commission

Uganda Human Rights Commission

Uganda Insurance Commission

Uganda Land Commission 


\section{PUBLIC ENTERPRISES IN UGANDA}

Cable Corporation Limited

Dairy Corporation

Development Finance Company of Uganda Limited

Housing Finance Company of Uganda Limited

Industrial Promotion Services

Kilembe Mines Limited

Kinyara Sugar Works Limited

Mandela Stadium

National Enterprise Corporation

National Housing and Construction Company Limited

National Insurance Corporation

National Medical Stores

National Water and Sewerage Corporation

New Vision Printing and Publishing Company Limited

Post Bank Uganda Limited

Print Pak Uganda Limited

Sugar Corporation of Uganda Limited

Uganda Aircargo Corporation

Uganda Consolidated Properties

Uganda Development Bank

Uganda Development Corporation

Uganda Electricity Distribution Company

Uganda Electricity Generating Company

Uganda Electricity Transmitting Company

Uganda Grain Milling Company Limited

Uganda Libyan Arab Holdings Limited

Uganda Livestock Industries Limited

Uganda Posts Limited

Uganda Printing and Publishing Corporation

Uganda Prison Industries Limited

Uganda Railways Corporation

Uganda Seed Limited

Uganda Telecoms Limited

UGMA Engineering Company Limited 


\section{APPENDIX 4 EXECUTIVE AGENCIES IN TANZANIA}

\begin{tabular}{|c|c|}
\hline Executive Agency & Year Launched and Role Description \\
\hline $\begin{array}{l}\text { 1. Agency for Development of Educational } \\
\text { Management (ADEM) }\end{array}$ & $\begin{array}{l}2001 \text { - Strengthens management capacity through } \\
\text { training, research and consultancy }\end{array}$ \\
\hline $\begin{array}{l}\text { 2. Business Registration and Licensing Agency } \\
\text { (BRELA) }\end{array}$ & $\begin{array}{l}1999 \text { - Facilitates orderly conduct of business and } \\
\text { provision of regulatory services }\end{array}$ \\
\hline $\begin{array}{l}\begin{array}{l}\text { 3. Drilling and Dam Construction } \\
\text { (DDCA) }\end{array} \\
\text { (Dgency } \\
\end{array}$ & $\begin{array}{l}1999 \text { - Improves efficiency and effectiveness of } \\
\text { the Government in the delivery of water supply }\end{array}$ \\
\hline $\begin{array}{l}\text { 4. Eastern Africa } \\
\text { (EASTC) }\end{array}$ & $\begin{array}{l}2002 \text { - Promotes evidence-based decision making } \\
\text { for policy makers/managers through statistical } \\
\text { information }\end{array}$ \\
\hline 5. Government Chemistry Laboratory (GCL) & $\begin{array}{l}1999 \text { - Analyses Food/Drugs; provides Chemicals } \\
\text { Management and Forensic Science }\end{array}$ \\
\hline 6. National Bureau of Statistics (NBS) & 1999 - Provides official statistics and services \\
\hline 7. National College of Tourism (NCT) & 2003 - Provides training in hotel and tourism \\
\hline $\begin{array}{l}\text { 8. National Housing and Building Research } \\
\text { Agency (NHBRA) }\end{array}$ & $\begin{array}{l}2001 \text { - Promotes utilization of local resources in to } \\
\text { reduce construction costs }\end{array}$ \\
\hline $\begin{array}{l}\text { 9. Occupational Safety and Health Agency } \\
\text { (OSHA) }\end{array}$ & $\begin{array}{l}2001 \text { - Promotes occupational safety and health to } \\
\text { eliminate accidents and occupational diseases }\end{array}$ \\
\hline 10. Tanzania Airports Authority (TAA) & 1999 - Provides airport services \\
\hline 11. Tanzania Building Agency (TBA) & $\begin{array}{l}2002 \text { - Provides and improves accommodation to } \\
\text { public servants through real estate management } \\
\text { and consultancies }\end{array}$ \\
\hline 12. Tanzania Civil Aviation Authority (TCAA) & $\begin{array}{l}1999-\text { Responsible for safety, security and } \\
\text { oversight of the aviation industry and the provision } \\
\text { of air navigation services }\end{array}$ \\
\hline 13. Tanzania Food and Drug Authority (TFDA) & $\begin{array}{l}2003 \text { - Protects consumers against health hazards } \\
\text { associated with food, drugs, cosmetics, etc. }\end{array}$ \\
\hline 14. Tanzania Government Flight (TGF) & $\begin{array}{l}2002 \text { - Provides air services to Head of State and } \\
\text { leaders; with spare capacity provides services on a } \\
\text { commercial basis }\end{array}$ \\
\hline 15. Tanzania Institute of Accountancy (TIA) & $\begin{array}{l}2003-\text { Provides education, research and } \\
\text { consultancy services in Accountancy, Materials } \\
\text { Management, etc. }\end{array}$ \\
\hline 16. Tanzania Meteorological Agency (TMA) & 1999 - Provides meteorological services \\
\hline $\begin{array}{lccc}\begin{array}{l}\text { 17. Tanzania } \\
\text { (TANROADS) }\end{array} & \text { National } & \text { Roads } & \text { Agency } \\
\end{array}$ & $\begin{array}{l}2000 \text { - Manages trunk and regional roads network } \\
\text { of about 35,000 kilometers in Mainland Tanzania }\end{array}$ \\
\hline 18. Tanzania Public Service College (TPSC) & $\begin{array}{l}2000 \text { - Trains public servants and others in public } \\
\text { administration an secretarial skills }\end{array}$ \\
\hline 19. Tanzania Revenue Authority (TRA) & 1996 - Manages tax administration \\
\hline 20. Tanzania Tree Seed Agency (TTSA) & 2003 - Provides forest products and tree seeds \\
\hline 21. Weights and Measures Agency (WMA) & $\begin{array}{l}2002 \text { - Protects consumers through measuring } \\
\text { systems that result in fair and just trade } \\
\text { transactions. }\end{array}$ \\
\hline
\end{tabular}

Source: President' Office, Public Service and Management. 2005. State of the Public Service Report 2004. Dar es Salaam. 
VITA

GENEVIEVE ENID KYARIMPA

$\begin{array}{ll}2004-\text { Present } & \begin{array}{l}\text { Teaching Assistant } \\ \text { Department of Public Administration, Florida International } \\ \text { University }\end{array} \\ 1996-\text { Present } & \begin{array}{l}\text { Lecturer } \\ \text { Makerere University, Kampala, Uganda }\end{array} \\ 1995-1996 & \begin{array}{l}\text { M. A. Public Policy and Administration, Institute of Social } \\ \text { Studies, The Hague, The Netherlands }\end{array} \\ 1991-1994 & \begin{array}{l}\text { Teaching Assistant } \\ \text { Makerere University, Kampala, Uganda }\end{array} \\ & \begin{array}{l}\text { B. A. Political Science and Public Administration, Makerere } \\ \text { University, Kampala, Uganda }\end{array}\end{array}$

PUBLICATIONS

2008. A Book Review of The Ethics Primer for Public Administrators in Government and Nonprofit Organizations. Svara James. 2007. Boston: Jones and Bartlett Publishers. In Public Organization Review, Vol. 8. No. 1, pgs 89-91.

2006. "The Quest for Public Service Ethics: Individual Conscience and Organizational Constraints." Public Money and Management, Vol. 26, No.1, pgs 31-38.

2005. "Civil Society and Political Participation in Uganda: Prospects for Consolidating Democracy." In Democratic Transitions in East Africa. Dar es Salaam: REDET Publications.

2002. "The History of Co-operation in East Africa, 1920-1996." In Politics, Governance, and Co-operation in East Africa, Saida Yahya-Othman (ed.) Dar es Salaam: REDET Publications.

2000. "Ethics in the Civil Service: Implications for the Civil Service Reform Programme in Uganda." African Journal of Public Administration and Management, Vol. 12, No.2, December, pgs 82-97.

1996. "Customer Service as an Element of the Civil Service Reform Programme in Uganda." Development and Socio-Economic Progress, AAPSO Quarterly No. 66, pgs 3953. 


\section{ACADEMIC AWARDS AND FELLOWSHIPS}

Aug. 23, 2002 - 2004: Florida International University Doctoral Studies Scholarship, and Milander Fellowship, Florida International University, Miami, Florida.

Aug. 26, 2001 - June 30, 2002: Rotary Ambassadorial Scholarship. The Joan B. Kroc Institute for Peace and Justice, University of San Diego, California, USA.

July 22 - August 17, 2001: Summer Institute in Political Psychology Fellowship, Ohio State University, Columbus, Ohio, USA.

Sept. 15 - Oct. 6, 2000: Training of Trainers Course offered by Crown Agents, funded by the Uganda Institutional Capacity Building Project, a World Bank - Government of Uganda Initiative, under the Ministry of Planning and Economic Development.

Aug. 28 - Sept. 2, 2000: African Association of Political Science Research Methods and Pedagogy Scholarship, University of Nairobi, Kenya.

Sept. 2 - Sept. 5, 1999: APSA Senior Scholar Travel Grant to attend the American Political Science Association Annual Meeting in Atlanta, Georgia, USA.

Sept. 15 - Dec.12, 1997: Commonwealth East African Visiting Scholarship Scheme. School of Oriental and African Studies (SOAS), University of London, London, UK.

June 28 - August 9, 1997: U.S.I.A Summer Institute on the American Political System, at Southern Illinois University, Carbondale, Illinois, USA.

Sept. 2, 1994 - Dec. 15, 1995: The Netherlands Fellowship Programme at the Institute of Social Studies, The Hague, Netherlands.

Aug. 1988 - July 1991: Government of Uganda, Makerere University Undergraduate Scholarship. 